\title{
USGS/WRIR--96-4256
}

\section{ANALYSIS OF WATER-LEVEL DATA IN THE YUCCA MOUNTAIN AREA, NEVADA, 1985-95}

U.S. GEOLOGICAL SURVEY

Water-Resources Investigations Report 96-4256

\section{RECEIVED \\ MAY 261998 \\ OSTI}

MASTER

Prepared in cooperation with the DISTPBUTION OF THS OOCUEN IS UNLATTED

NEVADA OPERATIONS OFFICE,

U.S. DEPARTMENT OF ENERGY, under

Interagency Agreement DE-AI08-92NV10874

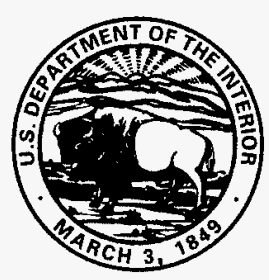




\section{ANALYSIS OF WATER-LEVEL DATA IN THE YUCCA MOUNTAIN AREA, NEVADA, 1985-95}

by Robert P. Graves, Patrick Tucci, and Grady M. O'Brien

U.S. GEOLOGICAL SURVEY

Water-Resources Investigations Report 96-4256

Prepared in cooperation with the

NEVADA OPERATIONS OFFICE,

U.S. DEPARTMENT OF ENERGY, under

Interagency Agreement DE-Al08-92NV10874 


\title{
U.S. DEPARTMENT OF THE INTERIOR BRUCE BABBITT, Secretary
}

\author{
U.S. GEOLOGICAL SURVEY
}

Gordon P. Eaton, Director

The use of firm, trade, and brand names in this report is for identification purposes only and does not constitute endorsement by the U.S. Geological Survey.

For additional information write to:

Chief, Earth Science Investigations Program Yucca Mountain Project Branch

U.S. Geological Survey

Box 25046, Mail Stop 421

Denver Federal Center

Denver, CO 80225-0046
Copies of this report can be purchased from:

U.S. Geological Survey

Branch of Information Services

Box 25286

Denver, CO 80225-0286 


\section{DISCLAIMER}

This report was prepared as an account of work sponsored by an agency of the United States Government. Neither the United States Government nor any agency thereof, nor any of their employees, makes any warranty, express or implied, or assumes any legal liability or responsibility for the accuracy, completeness, or usefulness of any information, apparatus, product, or process disclosed, or represents that its use would not infringe privately owned rights. Reference herein to any specific commercial product, process, or service by trade name, trademark, manufacturer, or otherwise does not necessarily constitute or imply its endorsement, recommendation, or favoring by the United States Government or any agency thereof. The views and opinions of authors expressed herein do not necessarily state or reflect those of the United States Government or any agency thereof. 


\section{CONTENTS}

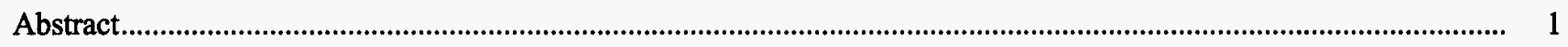

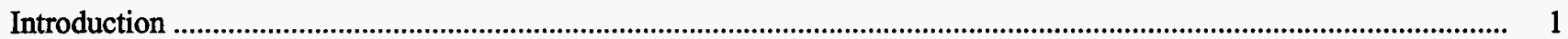

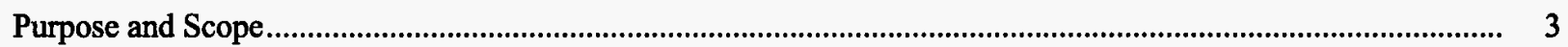

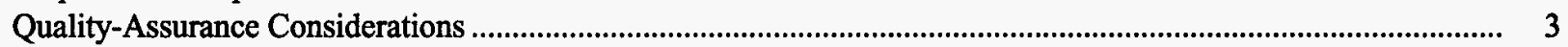

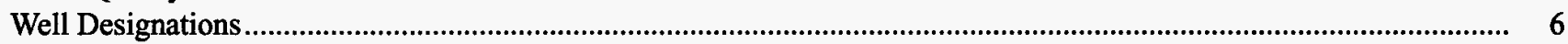

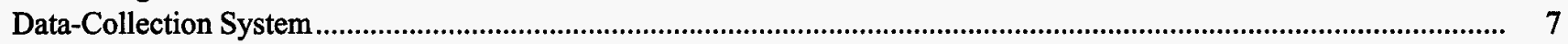

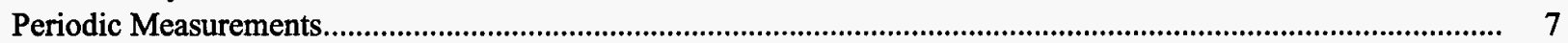

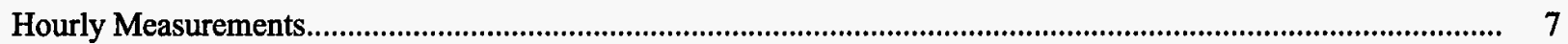

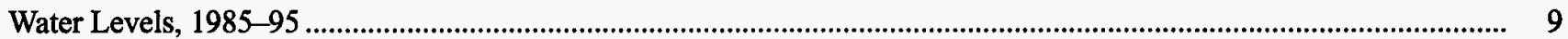

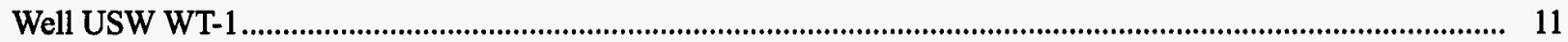

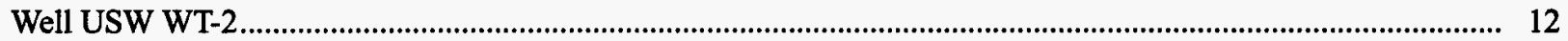

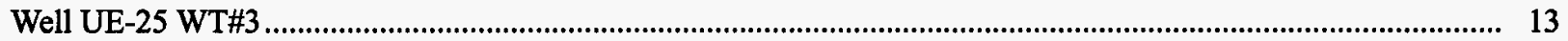

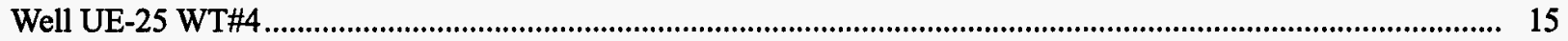

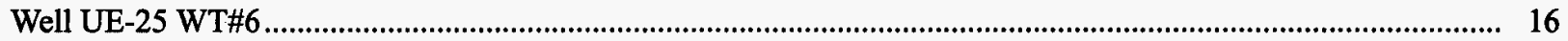

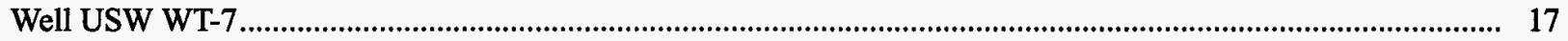

Well USW WT-10 ...................................................................................................................................... 18

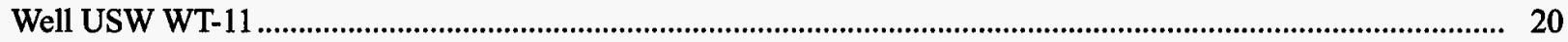

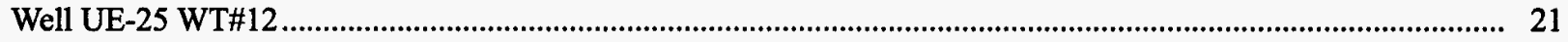

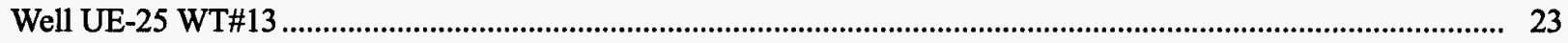

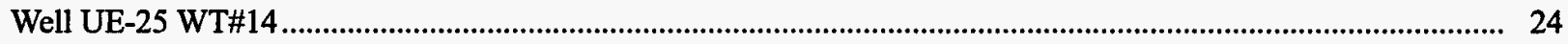

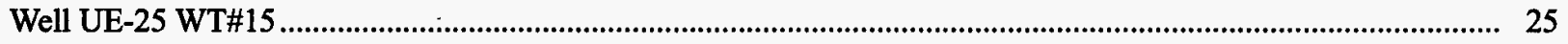

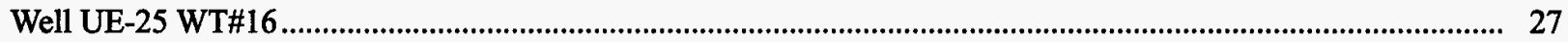

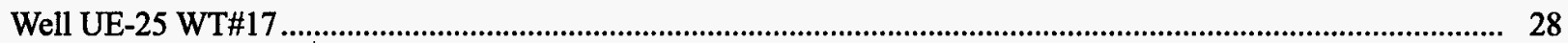

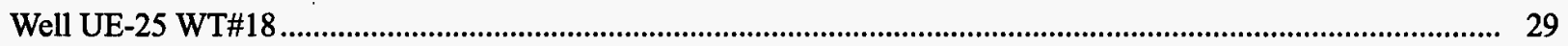

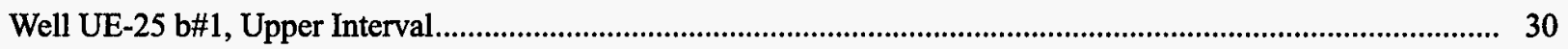

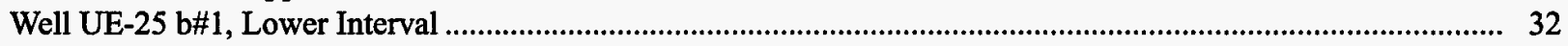

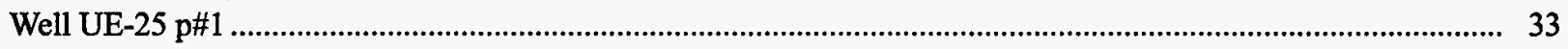

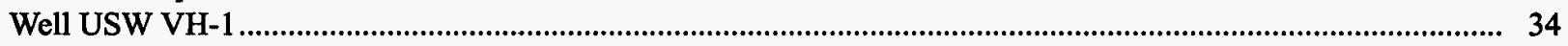

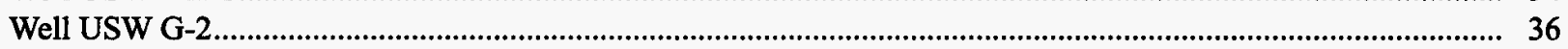

Well USW G-3

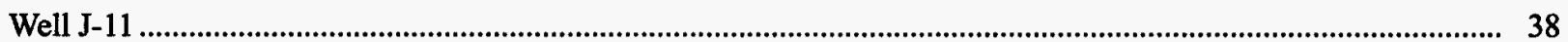

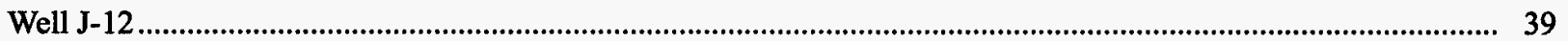

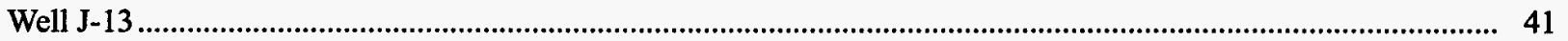

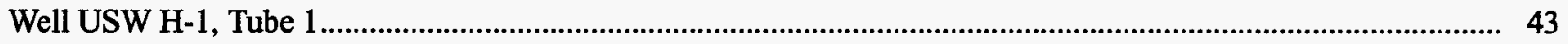

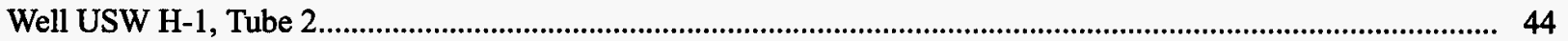

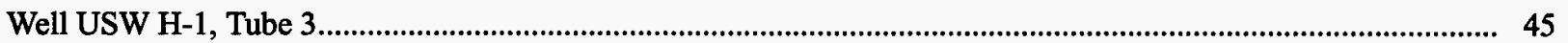

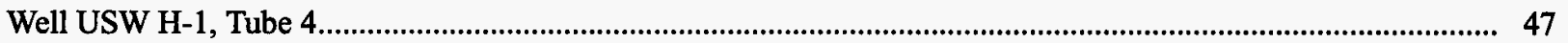

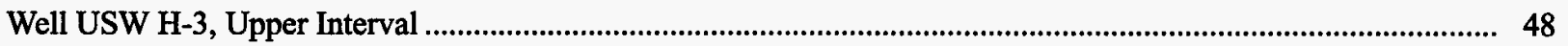

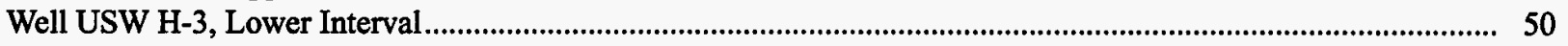

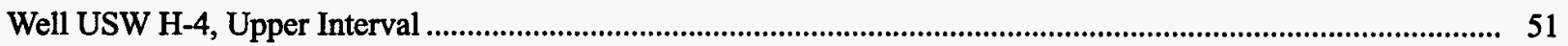

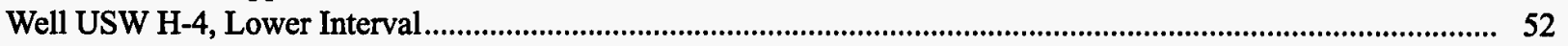

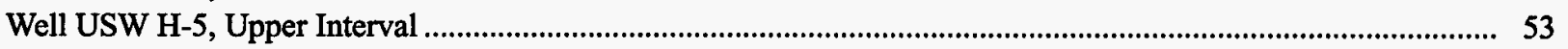

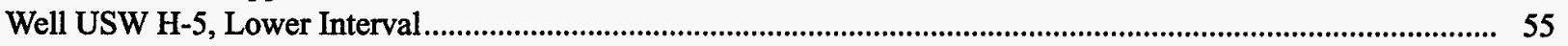

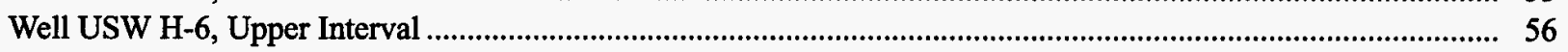

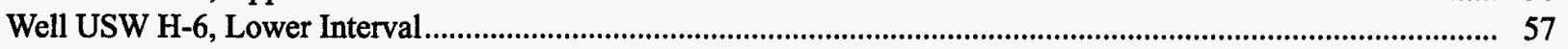

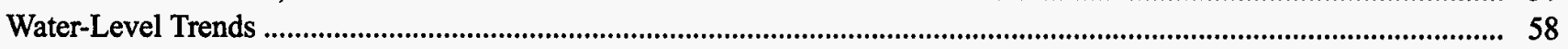

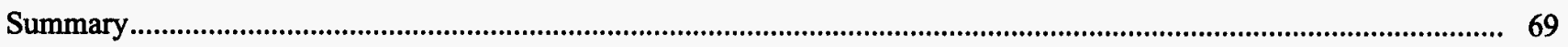

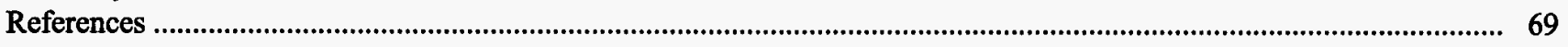

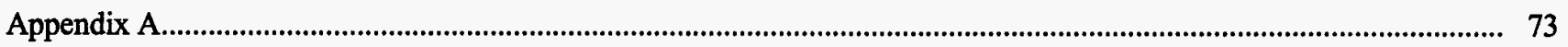

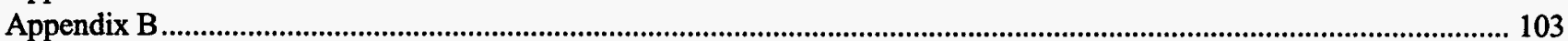




\section{FIGURES}

1. Map showing location of Yucca Mountain area and location of wells....................................................................... 2

2. Graph showing percentage of valid transducer data, 1985-95 .......................................................................... 8

3-45. Hydrographs showing water-level altitudes, 1985-95, for:
3. Well USW WT-1
4. Well USW WT-2
5. Well UE-25 WT\#3
6. Well UE-25 WT\#4
7. Well UE-25 WT\#6
8. Well USW WT-7
9. Well USW WT-10
10. Well USW WT-11
11. Well UE-25 WT\#12
12. Well UE-25 WT\#13
13. Well UE-25 WT\#14
14. Well UE-25 WT\#15
15. Well UE-25 WT\#16
16. Well UE-25 WT\#17
17. Well UE-25 WT\#18
18. Well UE-25 b\#1, upper interval
19. Well UE-25 b\#1, lower interval
20. Well UE-25 $\mathrm{p} \# 1$
21. Well USW VH-1
22. Well USW G-2.
23. Well USW G-3
24. Well J-11
25. Well J-12
26. Well J-13
27. Well USW H-1, tube 1
28. Well USW H-1, tube 2
29. Well USW H-1, tube 3
30. Well USW H-1, tube 4
31. Well USW H-3, upper interval
32. Well USW H-3, lower interval
33. Well USW H-4, upper interval
34. Well USW H-4, lower interval
35. Well USW H-5, upper interval
36. Well USW H-5, lower interval
37. Well USW H-6, upper interval
38. Well USW H-6, lower interval
39. Wells that may have been affected by the June 1992 earthquakes
40. Wells that are located along Fortymile Wash or in Jackass Flats
41. Wells located on top of Yucca Mountain
42. Wells located in Crater Flat
43. Wells with an approximate water-level altitude of 729 meters
44. Wells with an approximate water-level altitude of 730 meters
45. Wells with an approximate water-level altitude of 776 meters. 


\section{TABLES}

1. Summary of wells monitored for water levels in the Yucca Mountain area, Nevada

2. Statistical information, 1985-95, for wells and well intervals monitored in the Yucca Mountain area.

3. Yearly discharge from well USW VH-1.

4. Yearly discharge from well $\mathrm{J}-12$

5. Yearly discharge from well $\mathrm{J}-13$

\section{CONVERSION FACTORS, VERTICAL DATUM, AND ABBREVIATIONS}

\begin{tabular}{rll}
\hline Multiply & \multicolumn{1}{c}{ By } & To obtain \\
\hline cubic meter $\left(\mathrm{m}^{3}\right)$ & 264.2 & gallon \\
kilometer $(\mathrm{km})$ & 0.6214 & mile \\
$\operatorname{liter}(\mathrm{L})$ & 0.03531 & cubic foot \\
meter $(\mathrm{m})$ & 3.281 & foot \\
millimeter $(\mathrm{mm})$ & 0.03937 & inch \\
square kilometer $\left(\mathrm{km}^{2}\right)$ & 0.3861 & square mile \\
\hline
\end{tabular}

Sea level: In this report, "sea level" refers to the National Geodetic Vertical Datum of 1929 (NGVD of 1929) - a geodetic datum derived from a general adjustment of the first-order level nets of both the United States and Canada, formerly called Sea Level Datum of 1929. 


\title{
Analysis of Water-Level Data in the Yucca Mountain Area, Nevada, 1985-95
}

\author{
By Robert P. Graves, Patrick Tucci, and Grady M. O'Brien
}

\section{Abstract}

From 1985 through 1995, a water-level network that consists of 28 wells for monitoring 36 depth intervals has been maintained in the Yucca Mountain area. The network includes wells that were measured manually, approximately monthly, and/or measured hourly with a transducer/data logger system. Manual water-level measurements were made with either calibrated steel tapes or single or multiconductor-cable units. All wells monitor water levels in Tertiary volcanic rocks, except one that monitors water levels in Paleozoic carbonate rocks.

Annual mean water-level altitudes for all wells for the period 1985-95 ranged from 727.93 to $1,034.60$ meters. The maximum range in water-level change between monthly measurements and/or monthly mean values was 12.22 meters in well USW H-3 lower interval, and the minimum range was 0.31 meter in wells UE- $25 \mathrm{~b} \# 1$ upper interval, and J-11. In 31 of the 36 depth intervals monitored, the range of water-level change was less than 1 meter. The range of standard deviation of all depth interval measurements for all wells that were monitored was 0.053 to 3.098 meters.

No seasonal water-level trends were detected in any of the wells, and regional ground-water withdrawals did not appear to cause water-level changes. Most annual water-level fluctuations can be attributed to barometric and Earth-tide changes. Regional earthquakes, which occurred on June $28-29,1992$, might have simultaneously affected the water level in seven wells (UE-25 WT\#4, UE-25 WT\#6, USW WT-11, UE-25 WT\#12, UE-25 WT\#16, UE-25 b\#1 upper interval, and UE-25 p\#1).

The only consistent water-level changes observed between any two wells were between wells USW WT- 7 and USW WT-10, and between USW VH-1 and USW WT-7. Wells USW WT- 7 and USW WT-10 had similar water-level patterns from February 1989 through July 1992. Slight similarities were observed between wells USW VH-1 and USW WT-7 from September 1986 through February 1987, and from June 1993 through January 1994; however, these similarities were not as continuous or striking as those observed between USW WT-7 and USW WT-10.

Periods of rising and declining water levels were observed in most wells. However, 11 years of record were not sufficient to determine if these periods were cyclic. Because a goal of monitoring water levels at Yucca Mountain is to determine if there are water-level trends that could affect the potential repository, observed water-level changes over the period of this report may not be representative of the overall long-term trends in water levels. Subsequently, continuous long-term ground-water-level data need to be collected to determine conclusively if cyclic trends do exist.

\section{INTRODUCTION}

The Yucca Mountain area is being evaluated by the U.S. Department of Energy for suitability to store high-level nuclear waste in a mined, underground repository. A $150-\mathrm{km}^{2}$ area located about $150 \mathrm{~km}$ northwest of Las Vegas in southern Nevada is being studied extensively (fig. 1). Water levels in selected wells in the study area have been measured since 1981. The purpose of the water-level 


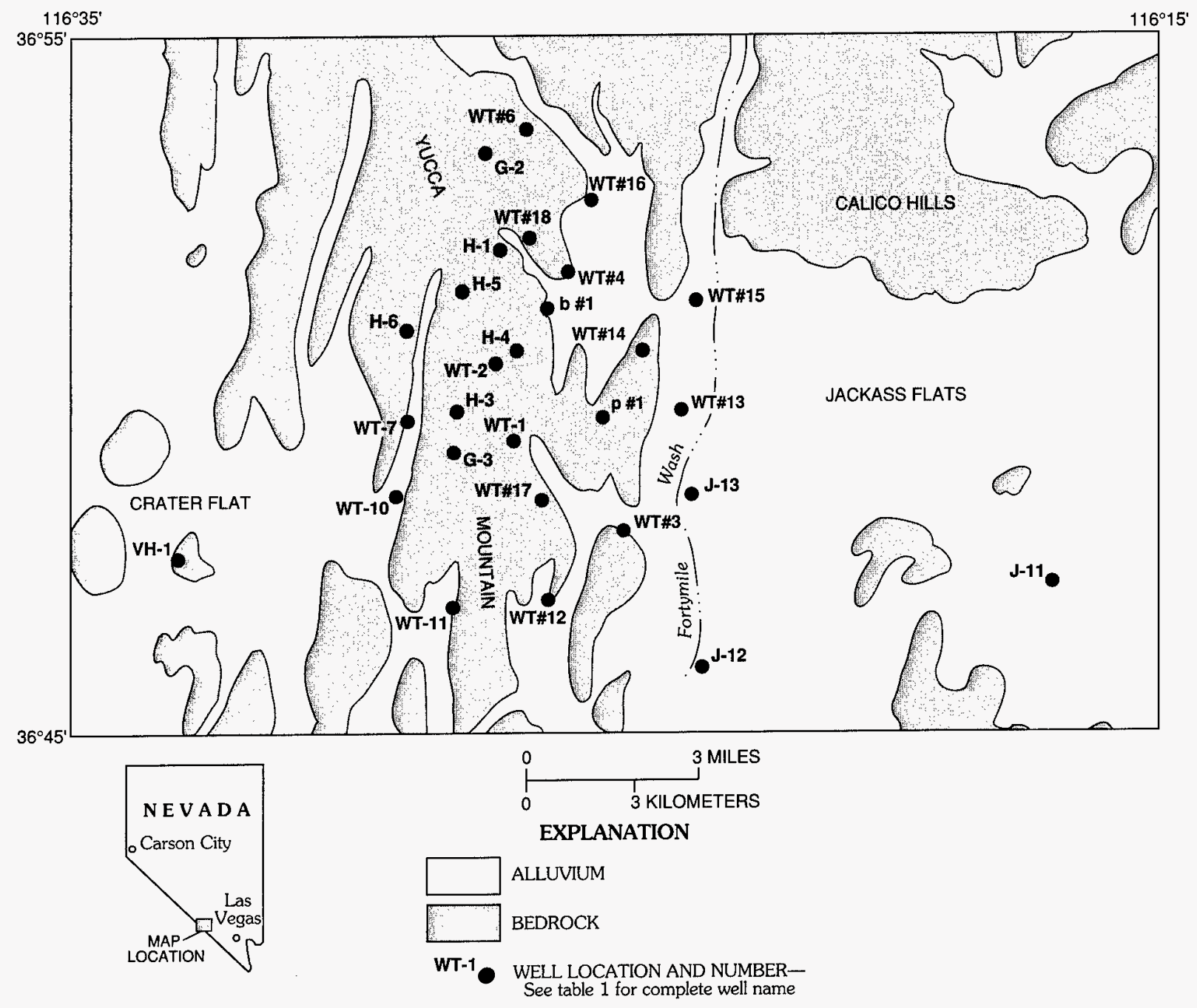

Figure 1. Location of Yucca Mountain area and location of wells. 
monitoring program is to gain a better understanding of the ground-water flow system in the area. The water-level data are used to determine the direction and rate of ground-water flow, to estimate hydraulic characteristics of the flow system, and to determine if there are ground-water trends that could affect the potential repository. Over the life span of the repository, there could be significant water-level rises or declines. In the Yucca Mountain area, the water table is in air-fall and ash-flow tuffs of Tertiary age. Saturated carbonate rocks of Paleozoic age underlie the Tertiary volcanic rocks. The geology and description of stratigraphic units in the study area were originally defined by Winograd and Thordarson (1975), Byers and others (1976), Carr and others (1986), and Carr (1988). The terminology for stratigraphic units in the study area used in this report has recently been renamed by Sawyer and others (1994).

\section{Purpose and Scope}

This report presents a summary and statistical analysis, in tabular and graphical form, of water-level data collected from 1985-95 for a network of 28 wells that monitor 36 depth intervals in the vicinity of Yucca Mountain (table 1). Wells in the network were monitored periodically by means of manual measurements and/or hourly when equipped with transducers. All wells monitor water levels in the various Tertiary volcanic rocks that underlie the Yucca Mountain area except well UE-25 p\#1, which monitors water levels in the Paleozoic carbonate rocks that underlie the volcanic rocks. Water-level data are presented as hydrographs of water-level altitudes for each well. Data sets for the hydrographs include manually measured water levels and/or monthly mean water-level averages of the hourly transducer data.

Periodic water-level data were collected, generally on a monthly schedule, using calibrated steel tapes or single or multiconductor cable units. Hourly water-level data were collected using pressure transducers and electronic data loggers. The transducer/data-logger systems are calibrated by recording transducer output at known depths of submergence. To obtain accurate transducer submergence information, manual water-level measurements are made using either the transducer or a calibrated steel tape or single or multiconductor cable unit. The water-level measurements made with a calibrated steel tape or single or multiconductor cable units may be adjusted for thermal expansion, mechanical stretch, equipment calibration, or borehole deviation from vertical. Hourly water-level altitudes are computed based on the transducer/data-logger calibration, the manual water-level measurement, and the surveyed altitude of the reference point. Detailed information concerning the data-collection equipment and methods are beyond the scope of this report. Such information has been documented by Robison and others (1988), Gemmell (1990), O'Brien (1991), Luckey and others (1993), Boucher (1994), Lobmeyer and others (1995), O'Brien and others (1995), Graves and others (1996), Tucci, Goemaat, and Burkhardt (1996), and Tucci, O'Brien, and Burkhardt (1996). Robison and others (1988) describe the details of how the manual water-level measurements were made and corrected to compute the water-level altitude.

The water-level data were obtained as part of the Yucca Mountain Project of the U.S. Department of Energy. The Yucca Mountain Project is described by a Site Characterization Plan (U.S. Department of Energy, 1988). The data in this study were collected by the U.S. Geological Survey and its contractors in cooperation with the U.S. Department of Energy under Interagency Agreement DE-AI08-92NV10874.

\section{Quality-Assurance Considerations}

Water-level data for Yucca Mountain and vicinity may be used to assess the expected performance of a high-level nuclear-waste repository, and confidence in the reliability of the data used in such an assessment is required. A quality-assurance program has been implemented by the U.S. Geological Survey for the Yucca Mountain Project to support the reliability of the data and interpretations of the data.

Data used by the Yucca Mountain Project are classified as either "qualified" or "unqualified." Qualified data are defined as "data acquired or developed for the Yucca Mountain Project under a Nuclear 
- Table 1. Summary of wells monitored for water levels in the Yucca Mountain area, Nevada

$[--$, data not available $]$

\begin{tabular}{|c|c|c|c|c|c|c|}
\hline Well name & $\begin{array}{l}\text { Date well } \\
\text { completed } \\
\text { (month/year) }\end{array}$ & $\begin{array}{l}\text { Drilled } \\
\text { depth } \\
\text { (meters) }\end{array}$ & $\begin{array}{l}\text { Depth below } \\
\text { land surface of } \\
\text { bottom of } \\
\text { monltoring } \\
\text { tube } \\
\text { (meters) }\end{array}$ & $\begin{array}{l}\text { Average, 1985-95 } \\
\text { depth to water } \\
\text { below reference } \\
\text { point } \\
\text { (meters) }\end{array}$ & $\begin{array}{l}\text { Mean, 1985-95, } \\
\text { water-level altitude } \\
\text { (meters) }\end{array}$ & $\begin{array}{l}\text { Method of monitoring } \\
\text { (month/year) }\end{array}$ \\
\hline USW WT-1 & $05 / 83$ & 515 & 507.5 & 470.76 & 730.35 & $\begin{array}{l}\text { Manually: 01/85-06/94, and 09/95-12/95 } \\
\text { Hourly: 07/94-08/95 }\end{array}$ \\
\hline USW WT-2 & $07 / 83$ & 628 & 622.0 & 570.48 & 730.65 & $\begin{array}{l}\text { Manually: } 01 / 85-08 / 86,09 / 93 \text { and } 10 / 93 \text {, and } 06 / 94-12 / 95 \\
\text { Hourly: } 09 / 86-08 / 93 \text { and } 12 / 93-05 / 94\end{array}$ \\
\hline UE-25 WT\#3 & $05 / 83$ & 348 & 343.0 & 300.47 & 729.64 & $\begin{array}{l}\text { Manually: } 01 / 85 \text { and } 02 / 85,11 / 89-04 / 92 \text {, and } 12 / 95 \\
\text { Hourly: } 03 / 85-12 / 88 \text { and } 05 / 92-09 / 95\end{array}$ \\
\hline UE-25 WT\#4 & $06 / 83$ & 482 & 477.6 & 438.43 & 730.78 & $\begin{array}{l}\text { Manually: } 01 / 85-04 / 93 \text { and } 09 / 95-12 / 95 \\
\text { Hourly: } 05 / 94-08 / 95\end{array}$ \\
\hline UE-25 WT\#6 & $06 / 83$ & 383 & 372.0 & 280.18 & $1,034.60$ & $\begin{array}{l}\text { Manually: } 01 / 85-06 / 86 \text { and } 03 / 92-12 / 95 \\
\text { Hourly: } 08 / 86-02 / 92\end{array}$ \\
\hline USW WT-7 & $07 / 83$ & 491 & 481.3 & 421.05 & 775.83 & Manually: $01 / 85-12 / 95$ \\
\hline USW WT-10 & $08 / 83$ & 431 & 402.6 & 347.40 & 776.00 & $\begin{array}{l}\text { Manually: } 01 / 85-06 / 94,09 / 95 \text {, and } 12 / 95 \\
\text { Hourly: } 07 / 94-08 / 95\end{array}$ \\
\hline USW WT-11 & $08 / 83$ & 441 & 416.0 & 363.45 & 730.66 & $\begin{array}{l}\text { Manually: } 01 / 85-10 / 86 \text { and } 07 / 94-12 / 95 \\
\text { Hourly: } 11 / 86-06 / 94\end{array}$ \\
\hline UE-25 WT\#12 & $08 / 83$ & 399 & 388.9 & 345.27 & 729.47 & Manually: $01 / 85-12 / 95$ \\
\hline UE-25 WT\#13 & $07 / 83$ & 354 & 346.0 & 303.40 & 729.11 & $\begin{array}{l}\text { Manually: } 01 / 85,02 / 85 \text {, and } 07 / 94-12 / 95 \\
\text { Hourly: } 03 / 85-06 / 94\end{array}$ \\
\hline UE-25 WT\#14 & $09 / 83$ & 399 & 397.2 & 346.37 & 729.68 & $\begin{array}{l}\text { Manually: } 01 / 85-06 / 94 \text { and } 12 / 95 \\
\text { Hourly: } 07 / 94-09 / 95\end{array}$ \\
\hline UE-25 WT\#15 & $11 / 83$ & 415 & 406.9 & 353.72 & 729.22 & Manually: $01 / 85-12 / 95$ \\
\hline UE-25 WT\#16 & $11 / 83$ & 521 & 514.0 & 472.36 & 738.27 & $\begin{array}{l}\text { Manually: } 01 / 85-08 / 86 \text { and } 05 / 92-12 / 95 \\
\text { Hourly: } 09 / 86-02 / 92\end{array}$ \\
\hline UE-25 WT\#17 & $10 / 83$ & 443 & 419.4 & 394.36 & 729.70 & Manually: $01 / 85-06 / 95$ \\
\hline UE-25 WT\#18 & $5 / 84$ & 623 & 609.0 & 605.57 & $\begin{array}{l}730.75 \\
\text { (average for } 91-95 \text { ) }\end{array}$ & Manually: $11 / 91-08 / 95$ \\
\hline $\begin{array}{l}\text { UE-25 b\#1 } \\
\text { upper interval }\end{array}$ & $09 / 81$ & 1,220 & 488.0 & 470.08 & 730.65 & $\begin{array}{l}\text { Manually: } 02 / 93-12 / 95 \\
\text { Hourly: } 09 / 85-01 / 93\end{array}$ \\
\hline $\begin{array}{l}\text { UE-25 b\#1 } \\
\text { lower interval }\end{array}$ & $09 / 81$ & 1,220 & $1,199.0$ & 471.06 & 729.67 & $\begin{array}{l}\text { Manually: } 02 / 90-03 / 92 \text { and } 11 / 92-07 / 95 \\
\text { Hourly: } 03 / 85-12 / 89 \text { and } 05 / 92-10 / 92\end{array}$ \\
\hline UE-25 p\#l & $05 / 83$ & 1,805 & 418.0 & 361.77 & 752.44 & Hourly: $03 / 85-12 / 95$ \\
\hline USW VH-1 & $02 / 81$ & 762 & 205.4 & 183.79 & 779.44 & Manually: $01105-12 / 95$ \\
\hline USW G-2 & $10 / 81$ & 1,831 & --1 & 533.69 & $\begin{array}{l}1,020.17 \\
\text { (average for } 92-95 \text { ) }\end{array}$ & $\begin{array}{l}\text { vranually: } 09 / 92-02 / 94 \text { and } 11 / 94-12 / 95 \\
\text { Hourly: 03/94-10/94 }\end{array}$ \\
\hline USW G-3 & $03 / 82$ & 1,533 & 792.0 & 749.97 & 730.50 & $\begin{array}{l}\text { Manually: } 01 / 85-03 / 86 \text { and } 05 / 94-06 / 95 \\
\text { Hourly: } 05 / 86-04 / 94\end{array}$ \\
\hline
\end{tabular}


Table 1. Summary of wells monitored for water levels in the Yucca Mountain area, Nevada --Continued

[---, data not available]

\begin{tabular}{|c|c|c|c|c|c|c|}
\hline Well name & $\begin{array}{c}\text { Date well } \\
\text { completed } \\
\text { (month/year) }\end{array}$ & $\begin{array}{c}\text { Drilled } \\
\text { depth } \\
\text { (meters) }\end{array}$ & $\begin{array}{l}\text { Depth below } \\
\text { land surface of } \\
\text { bottom of } \\
\text { monitoring } \\
\text { tube } \\
\text { (meters) }\end{array}$ & $\begin{array}{c}\text { Average, } 1985-95 \\
\text { depth to water } \\
\text { below reference } \\
\text { point } \\
\text { (meters) }\end{array}$ & $\begin{array}{c}\text { Mean, } 1985-95 \\
\text { water-level altitude } \\
\text { (meters) }\end{array}$ & $\begin{array}{l}\text { Method of monitoring } \\
\text { (month/year) }\end{array}$ \\
\hline $\mathrm{J}-11$ & $07 / 57$ & 405 & $--^{2}$ & 317.24 & $\begin{array}{c}732.21 \\
\text { (average for } 89-95 \text { ) }\end{array}$ & Manually: 01/89-12/95 \\
\hline $\mathrm{J}-12$ & $08 / 68$ & $347^{3}$ & --- & 226.61 & $\begin{array}{l}727.93 \\
\text { (average for } 89-95 \text { ) }\end{array}$ & Manually: 08/89-12/95 \\
\hline $\mathrm{J}-13$ & $01 / 63$ & 1,063 & --- & 283.03 & $\begin{array}{l}728.44 \\
\text { (average for } 86-95 \text { ) }\end{array}$ & Manually: 09/86-12/95 \\
\hline $\begin{array}{l}\text { USW H-1 } \\
\text { tube } 1\end{array}$ & $01 / 81$ & 1,829 & $1,806.0$ & 517.61 & 785.49 & $\begin{array}{l}\text { Manually: } 01 / 85-08 / 85,04 / 88-11 / 88 \text { and } 11 / 92-12 / 95 \\
\text { Hourly: } 10 / 85-11 / 87 \text { and } 03 / 89-10 / 92\end{array}$ \\
\hline $\begin{array}{l}\text { USW H-1 } \\
\text { tube } 2\end{array}$ & $01 / 81$ & 1,829 & $1,115.0$ & 567.13 & 735.97 & $\begin{array}{l}\text { Manually: } 08 / 85-11 / 88,04 / 91-10 / 91 \text { and } 06 / 93-12 / 95 \\
\text { Hourly: } 01 / 89-01 / 91 \text { and } 11 / 91-05 / 93\end{array}$ \\
\hline $\begin{array}{l}\text { USW H-1 } \\
\text { tube } 3\end{array}$ & $01 / 81$ & 1,829 & 741.0 & 572.50 & 730.60 & $\begin{array}{l}\text { Manually: } 12 / 95 \\
\text { Hourly: } 02 / 85-09 / 95\end{array}$ \\
\hline $\begin{array}{l}\text { USW H-1 } \\
\text { tube } 4\end{array}$ & $01 / 81$ & 1,829 & 640.0 & 572.25 & 730.85 & $\begin{array}{l}\text { Manually: } 10 / 95-12 / 95 \\
\text { Hourly: } 02 / 85-09 / 95\end{array}$ \\
\hline $\begin{array}{l}\text { USW H-3 } \\
\text { upper interval }\end{array}$ & $03 / 82$ & 1,219 & 762.0 & 751.95 & 731.52 & $\begin{array}{l}\text { Manually: } 01 / 85-10 / 85 \text { and } 02 / 91-07 / 91 \\
\text { Hourly: } 11 / 85-12 / 90 \text { and } 08 / 91-09 / 95\end{array}$ \\
\hline $\begin{array}{l}\text { USW H-3 } \\
\text { lower interval }\end{array}$ & $03 / 82$ & 1,219 & $1,114.0$ & 727.56 & $\begin{array}{l}755.91 \\
\text { (average for } 91-95 \text { ) }\end{array}$ & $\begin{array}{l}\text { Manually: } 02 / 91-06 / 91 \text { and } 10 / 95-12 / 95 \\
\text { Hourly: } 07 / 91-09 / 95\end{array}$ \\
\hline $\begin{array}{l}\text { USW H-4 } \\
\text { upper interval }\end{array}$ & $06 / 82$ & 1,219 & 525.0 & 518.34 & 730.40 & $\begin{array}{l}\text { Manually: } 02 / 85 \text { and } 12 / 95 \\
\text { Hourly: } 03 / 85-09 / 95\end{array}$ \\
\hline $\begin{array}{l}\text { USW } \mathrm{H}-4 \\
\text { lower interval }\end{array}$ & $06 / 82$ & 1,219 & $1,188.0$ & 518.23 & 730.51 & $\begin{array}{l}\text { Manually: } 12 / 95 \\
\text { Hourly: } 02 / 85-09 / 95\end{array}$ \\
\hline $\begin{array}{l}\text { USW H-5 } \\
\text { upper interval }\end{array}$ & $08 / 82$ & 1,219 & 709.0 & 703.48 & 775.46 & $\begin{array}{l}\text { Manually: } 01 / 85 \text { and } 02 / 85 \\
\text { Hourly: } 03 / 85-12 / 95\end{array}$ \\
\hline $\begin{array}{l}\text { USW H-5 } \\
\text { lower interval }\end{array}$ & $08 / 82$ & 1,219 & 846.0 & 703.32 & 775.62 & $\begin{array}{l}\text { Manually: } 01 / 85,02 / 85 \text {, and } 09 / 87 \\
\text { Hourly: } 06 / 90-12 / 95\end{array}$ \\
\hline $\begin{array}{l}\text { USW H-6 } \\
\text { upper interval }\end{array}$ & $10 / 82$ & 1,220 & 533.0 & 526.04 & 776.02 & $\begin{array}{l}\text { Manually: } 12 / 95 \\
\text { Hourly: } 08 / 85-09 / 95\end{array}$ \\
\hline $\begin{array}{l}\text { USW H-6 } \\
\text { lower interval }\end{array}$ & $10 / 82$ & 1,220 & 752.0 & 526.12 & 775.94 & $\begin{array}{l}\text { Manually: } 02 / 88-10 / 88 \text { and } 12 / 95 \\
\text { Hourly: } 04 / 89-09 / 95\end{array}$ \\
\hline
\end{tabular}

${ }^{1}$ Well measured through open casing. Well is open hole from 242 meters below land surface to bottom of well.

${ }^{2}$ Well measured through open casing. Well is cased to bottom of well. Casing is perforated from 328.3 to 334.4 meters below land surface and from 379.2 to 396.2 meters below land surface. ${ }^{3}$ Originally drilled to 27 meters in 1957; well deepened to 347 meters in 1968. 
Regulatory Commission-accepted quality-assurance plan or qualified in accordance with appropriate Yucca Mountain Project procedures. Developed data cannot be classified as 'Qualified' if derived from unqualified data sources" (U.S. Department of Energy, written commun., 1993). An example of "developed" data is a water-level altitude that is calculated from a depth-to-water measurement, altitude of measuring point, and various correction factors.

Depth-to-water measurements collected at Yucca Mountain after 1989 are obtained in accordance with approved Yucca Mountain Project quality-assurance procedures, and these uncorrected measurements are classified as qualified data. However, measuring point altitudes and data used to calculate correction factors, such as borehole-temperature and borehole-deviation data, were obtained prior to the implementation of the accepted Yucca Mountain Project quality-assurance program in 1989. Therefore, these data and the calculated water-level altitudes presented in this report are classified as unqualified data. Uncorrected, depth-to-water measurements collected before the implementation of the Yucca Mountain Project quality-assurance program in 1989 are also classified as unqualified data.

\section{WELL DESIGNATIONS}

Each well used in the study of the Yucca Mountain area has a unique name or number. Wells on the Nevada Test Site (NTS) use an NTS designation, whereas wells off the NTS use a slightly different designation. Wells on the NTS begin with UE (for Underground Exploratory), followed by the NTS area number (always 25 in this report). This designation-UE-25-commonly is followed by one or more letters signifying the purpose of the well or simply by a sequential letter, followed by a sequence number. Wells off the NTS begin with the letters USW (for Underground, Southern Nevada, Waste). The designation-USW - is followed by one or more letters signifying the primary purpose of the well followed by a sequence number. The letters signifying purpose that are used in this report are $\mathrm{G}$ (collection of geologic data), $\mathrm{H}$ (collection of hydrologic data), p (collection of data on rocks of Paleozoic age), VH (collection of hydrologic and geologic data of volcanic rocks) and WT (collection of water-table data). The only wells not using this designation system and referred to in this report are wells $\mathrm{J}-11, \mathrm{~J}-12$, and $\mathrm{J}-13$, which were drilled as water-supply wells.

Nevada State Coordinates are used to identify the location of wells cited in this report (Appendix A). These coordinates are for the central zone of Nevada and are based on a Transverse Mercator projection. The origin of this projection for the central zone of Nevada is latitude $34^{\circ} 45^{\prime} \mathrm{N}$., and the central meridian is at longitude $116^{\circ} 40^{\prime} \mathrm{W}$. The Nevada State Coordinates are in meters north of the baseline and in meters, plus 152,400 east of the central meridian. The Nevada State Coordinate locations for the wells were determined by Holmes \& Narver, Inc., contractor to the U.S. Department of Energy for surveying at the NTS and Yucca Mountain area. Latitude and longitude values of the wells were calculated from the Nevada State Coordinates.

The Site ID number is used for unique identification of the well in the U.S. Geological Survey's data bases. The Site ID is generated by combining the original designations of the latitude and longitude with a two-digit sequence number. The Site ID is for convenience of identification only and should not be used as an actual location number because the original designations of latitude and longitude may be inaccurate. Even if original values of the latitude and longitude are revised later, the Site ID for the well is not changed. If more than one well exists within the 1-second rectangle of latitude and longitude, the two-digit sequence number is used to ensure uniqueness of the Site ID. The Site ID for all wells discussed in this report are found in Appendix A.

Some wells within the water-level network have had packers or piezometers installed so the water level at discrete intervals can be measured. In these instances, before the packers or piezometers were installed, the well was assigned one Site ID (generally with a sequence number of 01), and prior to 1990, each depth interval was assigned its own unique Site ID by incrementing the sequence number. Hence, some wells within the network have several Site ID's. However, since 1990, the water-level data are generally stored in the National Water Information System (NWIS) data base under the Site ID with sequence number 01. Exceptions are wells USW H-5 and UE-25 p\#1, which use the Site ID with sequence 
number 02 . For those wells that have more than one zone monitored, the water levels are kept distinct in NWIS with the use of data descriptors, which define each unique zone.

\section{DATA-COLLECTION SYSTEM}

Water-level data from wells at Yucca Mountain are collected by means of manual measurements, which are collected periodically, and by use of pressure transducers that are monitored hourly by data loggers. Periodic manual measurements are discussed first, followed by a discussion of the hourly pressure-transducer system. All water-level measurements are subject to various corrections, and these corrections are also discussed. For the following discussion, refer to table 1 to see when a well was designated as a manually measured well and/or as a well monitored hourly with the pressure-transducer system.

\section{Periodic Measurements}

Periodic, manual, water-level measurements at wells require visits by trained personnel who perform specific operations and record the results. Operational plans for 1985-95 called for measurements once per month at each well. However, measurement frequency varied; water levels in some wells were measured more frequently to document anticipated changes in the water table, or less frequently because of factors such as temporary shortage of trained personnel, breakdown of equipment, or well-site inaccessibility due to road washouts. Manual water-level measurements also are made at wells monitored hourly when it is necessary to replace a defective transducer or at selected times of transducer calibration.

Periodic measurements primarily were made using specially constructed reeled steel tapes that range in length from 792 to $853 \mathrm{~m}$. Additional measurements were made in some wells using a single or multiconductor-cable unit. Detailed descriptions of steel tapes and the single and multiconductor cable units used to measure water levels for this study are given by Robison and others (1988), O'Brien (1991), and Luckey and others (1993) and are not repeated here.

Various factors affect the accuracy of manual water-level measurements and are considered in the process of determining an accurate depth below land surface and the water-level altitude. All measurements in this report have been corrected to obtain the most accurate water-level altitudes.

Corrections made for steel-tape water-level measurements include mechanical stretch and thermal expansion of the tape. Single or multiconductor-cable measurements are corrected using a regression equation obtained during calibration of the unit. All measurements, except those at wells $\mathrm{J}-11, \mathrm{~J}-12$, and $\mathrm{J}-13$ are corrected for borehole deviation from vertical. Borehole-deviation information is not available for wells J-11, J-12, and J-13. All measurements are referenced to sealevel datum. Detailed information concerning corrections to the data are documented in individual water-level data reports for specific years that are listed in the "References" section.

\section{Hourly Measurements}

Hourly water-level measurements require that equipment be installed in the well to record water levels. Trained personnel install the equipment in the well, periodically calibrate equipment or replace it as necessary, and periodically retrieve the data from the site. Hourly measurements are of a sufficient frequency that water-level fluctuations are adequately defined to evaluate daily or longer-term trends. Hourly measurements were stored and later retrieved from the data loggers at each site.

Pressure transducers and data loggers are used to measure the hourly water-level fluctuations. Because of the large depths to water (up to $752 \mathrm{~m}$ ), traditional water-level sensing methods, such 
as float-cable-pulley system, water-seeking device, and bubble tube are not feasible. However, electronic signals from a submerged pressure transducer are relatively easy to transmit through a multi-conductor suspension cable to a recording device accessible to personnel on the surface. Electronic data loggers at the surface are used to control, measure, and store data from the pressure transducers.

The water-level monitoring systems are calibrated at least every 4 months. The calibration always includes a water-level measurement. The water-level measurements are made using either the transducer, a steel tape, or single or multiconductor cable unit. The water-level measurements, after adjustments, result in altitudes of water surface at the time of calibration.

The data stored in the data loggers and transferred to computers are not water-level data but rather transducer output, in millivolts. The transducer output are converted to water levels using methods described in Luckey and others (1993), Lobmeyer and others (1995), O'Brien and others (1995), Graves and others (1996), Tucci, Goemaat, and Burkhardt (1996), and Tucci, O'Brien, and Burkhardt (1996). The water-levels are then evaluated by two senior project staff members or other hydrologists. Anomalous data points, such as those produced during transducer calibrations, by random electronic signal, or due to instrument malfunction are not retained as water levels.

In an ideal circumstance, a transducer would be calibrated several times during its operating life, its output would be free of drift, and its characteristics would not change with time. However, this ideal situation rarely occurs, causing the transducer output conversion to water levels to be more difficult. As a result, some of the transducer output and resulting converted water levels are not considered reliable and could not be used. Improvements in equipment and data-collection procedures resulted in an increase in the percentage of valid transducer data from 56 percent (1985-88) to 86 percent by 1992 (O'Brien, 1994) to 94 percent in 1994, and to 96 percent in 1995 (fig. 2).

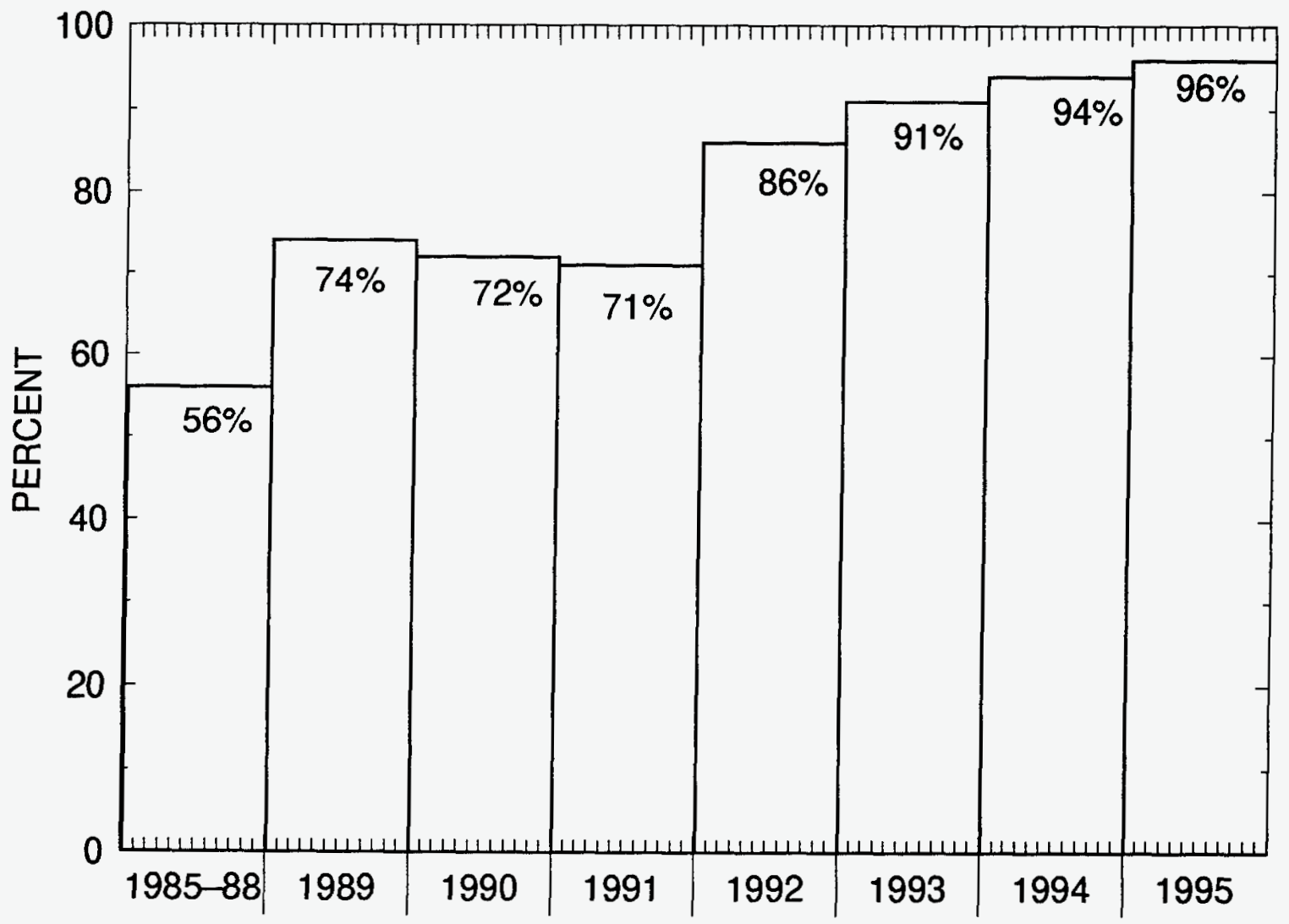

Figure 2. Percentage of valid transducer data, 1985-95. 


\section{WATER LEVELS, 1985-95}

This section presents water-level data collected for 28 wells, monitoring 36 depth intervals, which were measured from 1985-95. The data are presented as hydrographs of periodic manually measured water levels and/or monthly mean water levels of hourly transducer data. Because both methods of data collection were used for most wells and most manual measurements were obtained monthly, this format of data presentation was chosen in order to have a reasonably uniform distribution of data with time. Hydrographs are generally plotted with a Y-axis span of $2.5 \mathrm{~m}$ and an X-axis time span of 1985-95 (exceptions to this are wells UE-25 WT\#6, which has a Y-axis span of $3.5 \mathrm{~m}$, and USW H-3, lower interval, which has a Y-axis span of $14 \mathrm{~m}$ ).

Monthly mean water-level altitudes were averaged from daily mean values of the hourly transducer data. Because there were periods when the transducer data were questionable and the data could not be used, the monthly mean water-level altitudes were not always averaged from a complete month of record. However, regardless of the number of days of missing record, as long as some hourly data were available, a monthly mean water level was calculated. This was done because of the general trend of little waterlevel change in each well and because the monthly mean data was plotted with manual measurements that generally were collected only once a month.

Statistical information is presented for each well (table 2). The statistical information, which includes the minimum, maximum, range, mean, median, and standard deviation was calculated from the water-level data used to plot each hydrograph (Appendix B). Because monthly mean water-level altitudes were used to determine the minimum, maximum, and range of water levels for many wells, slightly larger ranges of water-level change (usually on the order of hundredths of a meter) are discussed in previously published U.S. Geological Survey reports of annual water-level data. This difference in range of water-level change is due to the use of hourly unit values to plot hydrographs in these reports instead of monthly mean values that are used in this report. For wells that were never instrumented with transducers and only manual water-level measurements made, there should be no difference in the range of values.

Annual mean water levels are also presented for each well. Depending on the method of data collection, mean annual water levels typically are averaged from daily mean values of the hourly transducer data, or averaged from the manual measurements of the periodic data. However, for this report, depending on the frequency of data collection, mean annual water levels were calculated from either the average of the monthly mean transducer data or manual periodic data (Appendix B). For wells monitored hourly for only part of the year, manual measurements were used for the months that hourly data were not available. Where more than one manual measurement was made during the month for any well, the average of these measurements were used for the monthly value.

Pertinent information for each well, such as well-construction and the geologic formation the well is completed in, is listed in Appendix A. The data sets of manual measurements and monthly mean waterlevel data used to plot each well hydrograph are presented in Appendix B. Complete water-level data, including hourly measurements, are archived in the U.S. Geological Survey computer data base. This information may be obtained from the Chief, Earth Science Investigations Program, Yucca Mountain Project Branch, U.S. Geological Survey, Box 25046, MS-421, Denver Federal Center, Denver, CO 80225. 
Table 2. Statistical information, 1985-95, for wells and well intervals monitored in the Yucca Mountain area

[Statistical information calculated from water-level data used to plot hydrographs for each well (Appendix B). Hydrograph data is from monthly mean water levels computed from daily mean values or from periodic manual water-level measurements.]

\begin{tabular}{|c|c|c|c|c|c|c|c|}
\hline Well name & $\begin{array}{l}\text { Minimum } \\
\text { water-level } \\
\text { altitude } \\
\text { (meters) }\end{array}$ & $\begin{array}{l}\text { Maximum } \\
\text { water-level } \\
\text { altitude } \\
\text { (meters) }\end{array}$ & $\begin{array}{c}\text { Range } \\
\text { (meters) }\end{array}$ & $\begin{array}{c}\text { Mean } \\
\text { water-level } \\
\text { altitude } \\
\text { (meters) }\end{array}$ & $\begin{array}{c}\text { Median } \\
\text { water-level } \\
\text { altitude } \\
\text { (meters) }\end{array}$ & $\begin{array}{l}\text { Standard } \\
\text { deviation } \\
\text { (meters) }\end{array}$ & $\begin{array}{l}\text { Number of } \\
\text { data points } \\
\text { used }\end{array}$ \\
\hline USW WT-1 & 729.98 & 730.50 & 0.52 & 730.35 & 730.35 & 0.092 & 128 \\
\hline USW WT-2 & 730.14 & 730.81 & 0.67 & 730.65 & 730.70 & 0.128 & 106 \\
\hline UE-25 WT\#3 & 729.41 & 729.85 & 0.44 & 729.64 & 729.70 & 0.126 & 119 \\
\hline UE-25 WT\#4 & 730.28 & 731.17 & 0.89 & 730.78 & 730.81 & 0.118 & 131 \\
\hline UE-25 WT\#6 & $1,033.29$ & $1,036.09$ & 2.80 & $1,034.60$ & $1,034.52$ & 0.553 & 117 \\
\hline USW WT-7 & 775.47 & 775.99 & 0.52 & 775.83 & 775.85 & 0.096 & 113 \\
\hline USW WT-10 & 775.56 & 776.21 & 0.65 & 776.00 & 776.00 & 0.114 & 132 \\
\hline USW WT-11 & 730.21 & 730.81 & 0.60 & 730.66 & 730.69 & 0.099 & 119 \\
\hline UE-25 WT\#12 & 729.11 & 729.58 & 0.47 & 729.47 & 729.48 & 0.074 & 123 \\
\hline UE-25 WT\#13 & 728.53 & 729.43 & 0.90 & 729.11 & 729.14 & 0.119 & 118 \\
\hline UE-25 WT\#14 & 729.29 & 729.98 & 0.69 & 729.68 & 729.69 & 0.073 & 135 \\
\hline UE-25 WT\#15 & 728.98 & 729.42 & 0.44 & 729.22 & 729.22 & 0.070 & 124 \\
\hline UE-25 WT\#16 & 737.82 & 738.57 & 0.75 & 738.27 & 738.29 & 0.147 & 123 \\
\hline UE-25 WT\#17 & 729.45 & 729.84 & 0.39 & 729.70 & 729.72 & 0.083 & 117 \\
\hline UE-25 WT\#18 & 730.52 & 730.92 & 0.40 & 730.75 & 730.76 & 0.095 & 38 \\
\hline $\begin{array}{l}\text { UE-25 b\#1 } \\
\text { upper interval } \\
\text { lower interval }\end{array}$ & $\begin{array}{l}730.48 \\
728.52\end{array}$ & $\begin{array}{l}730.79 \\
730.25\end{array}$ & $\begin{array}{l}0.31 \\
1.73\end{array}$ & $\begin{array}{l}730.65 \\
729.67\end{array}$ & $\begin{array}{l}730.63 \\
729.77\end{array}$ & $\begin{array}{l}0.065 \\
0.425\end{array}$ & $\begin{array}{l}99 \\
67\end{array}$ \\
\hline UE-25 p\#1 & 751.92 & 752.69 & 0.77 & 752.44 & 752.49 & 0.161 & 120 \\
\hline USW VH-1 & 779.30 & 779.60 & 0.30 & 779.44 & 779.45 & 0.048 & 147 \\
\hline USW G-2 & $1,019.58$ & ${ }^{1} 1,020.56$ & 0.98 & $1,020.17$ & $1,020.12$ & 0.241 & 28 \\
\hline USW G-3 & 729.96 & 730.83 & 0.87 & 730.50 & 730.51 & 0.169 & 113 \\
\hline $\mathrm{J}-11$ & 732.09 & 732.40 & 0.31 & 732.21 & 732.20 & 0.055 & 71 \\
\hline $\mathrm{J}-12$ & 727.81 & 728.15 & 0.34 & 727.93 & 727.94 & 0.053 & 100 \\
\hline $\mathrm{J}-13$ & 728.30 & 728.69 & 0.39 & 728.44 & 728.44 & 0.065 & 121 \\
\hline $\begin{array}{c}\text { USW H-1 } \\
\text { tube } 1 \\
\text { tube } 2 \\
\text { tube } 3 \\
\text { tube } 4\end{array}$ & $\begin{array}{l}785.00 \\
735.67 \\
730.35 \\
730.51\end{array}$ & $\begin{array}{l}786.05 \\
736.28 \\
730.81 \\
731.04\end{array}$ & $\begin{array}{l}1.05 \\
0.61 \\
0.46 \\
0.53\end{array}$ & $\begin{array}{l}785.49 \\
735.97 \\
730.60 \\
730.85\end{array}$ & $\begin{array}{l}785.49 \\
735.95 \\
730.62 \\
730.90\end{array}$ & $\begin{array}{l}0.272 \\
0.161 \\
0.098 \\
0.126\end{array}$ & $\begin{array}{r}101 \\
75 \\
108 \\
124\end{array}$ \\
\hline $\begin{array}{l}\text { USW H-3 } \\
\text { upper interval } \\
\text { lower interval }\end{array}$ & $\begin{array}{l}731.07 \\
747.39\end{array}$ & $\begin{array}{l}731.93 \\
759.61\end{array}$ & $\begin{array}{r}0.86 \\
12.22\end{array}$ & $\begin{array}{l}731.52 \\
755.91\end{array}$ & $\begin{array}{l}731.41 \\
756.80\end{array}$ & $\begin{array}{l}0.287 \\
3.098\end{array}$ & $\begin{array}{r}128 \\
59\end{array}$ \\
\hline $\begin{array}{l}\text { USW H-4 } \\
\text { upper interval } \\
\text { lower interval }\end{array}$ & $\begin{array}{l}730.20 \\
730.18\end{array}$ & $\begin{array}{l}730.52 \\
730.83\end{array}$ & $\begin{array}{l}0.32 \\
0.65\end{array}$ & $\begin{array}{l}730.40 \\
730.51\end{array}$ & $\begin{array}{l}730.40 \\
730.52\end{array}$ & $\begin{array}{l}0.061 \\
0.108\end{array}$ & $\begin{array}{l}128 \\
101\end{array}$ \\
\hline $\begin{array}{l}\text { USW H-5 } \\
\text { upper interval } \\
\text { lower interval }\end{array}$ & $\begin{array}{l}774.96 \\
774.95\end{array}$ & $\begin{array}{l}775.72 \\
775.86\end{array}$ & $\begin{array}{l}0.76 \\
0.91\end{array}$ & $\begin{array}{l}775.46 \\
775.62\end{array}$ & $\begin{array}{l}775.47 \\
775.64\end{array}$ & $\begin{array}{l}0.139 \\
0.186\end{array}$ & $\begin{array}{r}106 \\
54\end{array}$ \\
\hline $\begin{array}{l}\text { USW H-6 } \\
\text { upper interval } \\
\text { lower interval }\end{array}$ & $\begin{array}{l}775.83 \\
775.71\end{array}$ & $\begin{array}{c}776.20 \\
776.08\end{array}$ & $\begin{array}{l}0.37 \\
0.37\end{array}$ & $\begin{array}{l}776.02 \\
775.94\end{array}$ & $\begin{array}{l}776.03 \\
775.95\end{array}$ & $\begin{array}{l}0.087 \\
0.070\end{array}$ & $\begin{array}{r}118 \\
79\end{array}$ \\
\hline
\end{tabular}

${ }^{1}$ The water level in well USW G-2 has been declining since the well was completed on 10-24-81. Altitude of water level on 11-10-81 was 1,031.82 meters (U.S. Geological Survey historical records). Altitude of water level on 09-17-82 was 1,028.84 meters (Robison and others, 1988). Range of water-level change since $11-01-81$ is 12.24 meters. 


\section{Well USW WT-1}

Water-level altitudes for well USW WT-1 ranged from 729.98 to $730.50 \mathrm{~m}$ above sea level from 1985-95 (fig. 3). The mean annual water-level altitude for $1985-95$ was $730.35 \mathrm{~m}$ above sea level. The median water-level altitude was also $730.35 \mathrm{~m}$. Standard deviation was $0.092 \mathrm{~m}$. The annual mean water-level altitudes for $1985-95$ are as follows:

\begin{tabular}{cc}
\hline Year & $\begin{array}{c}\text { Annual mean } \\
\text { water-level altitude } \\
\text { (meters) }\end{array}$ \\
\hline 1985 & 730.23 \\
1986 & 730.32 \\
1987 & 730.35 \\
1988 & 730.40 \\
1989 & 730.42 \\
1990 & 730.42 \\
1991 & 730.42 \\
1992 & 730.37 \\
1993 & 730.28 \\
1994 & 730.31 \\
1995 & 730.32 \\
\hline
\end{tabular}

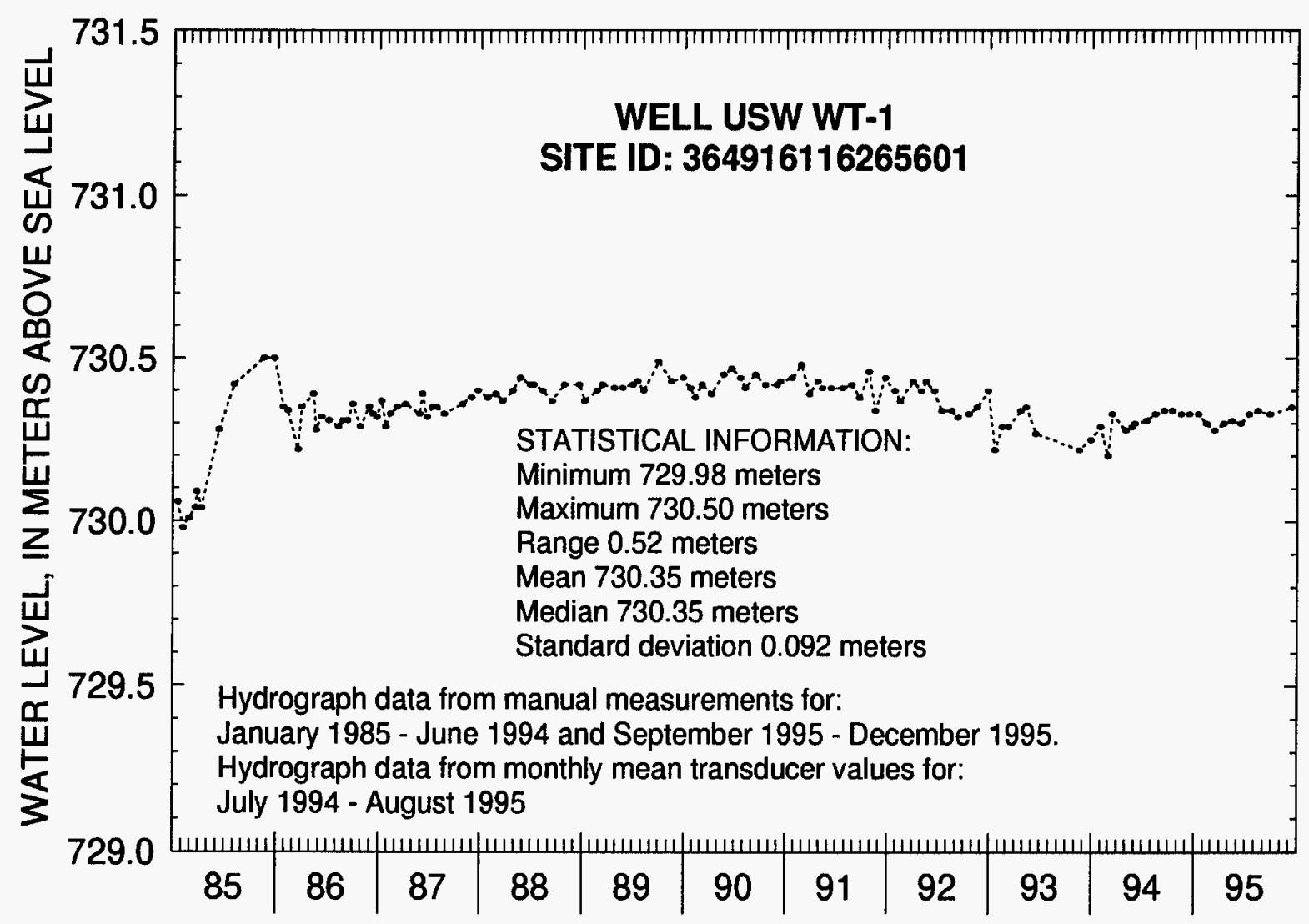

Figure 3. Water-level altitudes, 1985-95, for well USW WT-1. 
Neither distinct seasonal trends in water-level changes or effects due to regional groundwater withdrawals were observed in well USW WT-1. Most changes in the water level can be attributed to barometric and Earth-tide changes. The anomalous rise in water level during mid1985 and apparent decline during early 1986 corresponds to a change in measuring equipment and probably were not actual water-level changes (Robison and other, 1988). Excluding data prior to March 1986, over the 10 years of remaining record, there is a gradual rise in water level from March 1986 through February 1991, followed by a decline in water level from March 1991 until March 1, 1994 (Appendix B), and then another overall rise in water level after this date through December 1995. To determine if this is a cyclic pattern, continuous long-term water-level data need to be collected.

\section{Well USW WT-2}

Water-level altitudes for well USW WT-2 ranged from 730.14 to $730.81 \mathrm{~m}$ above sea level from 1985-95 (fig. 4). The mean annual water-level altitude for $1985-95$ was $730.65 \mathrm{~m}$ above sea level. The median value was $730.70 \mathrm{~m}$. Standard deviation was $0.128 \mathrm{~m}$. The annual mean waterlevel altitudes for $1985-95$ are as follows:

\begin{tabular}{ll}
\hline Year & $\begin{array}{c}\text { Annual mean } \\
\text { water-level altitude } \\
\text { (meters) }\end{array}$ \\
\hline 1985 & 730.35 \\
1986 & 730.58 \\
1987 & 730.61 \\
1988 & 730.72 \\
1989 & 730.74 \\
1990 & 730.76 \\
1991 & 730.79 \\
1992 & 730.71 \\
1993 & 730.67 \\
1994 & 730.53 \\
1995 & 730.57 \\
\hline
\end{tabular}

Neither distinct seasonal trends in water-level changes or effects due to regional groundwater withdrawals were observed in well USW WT-2. Most changes in the water level can be attributed to barometric and Earth-tide changes. Over the 11 years of record, there is a gradual rise in water level from January 1985 through December 1991, followed by a decline in water level from January 1992 through December 1993, and then another rise in water level from January 1994 through December 1995. To determine if this is a cyclic pattern, continuous long-term water-level data need to be collected. 


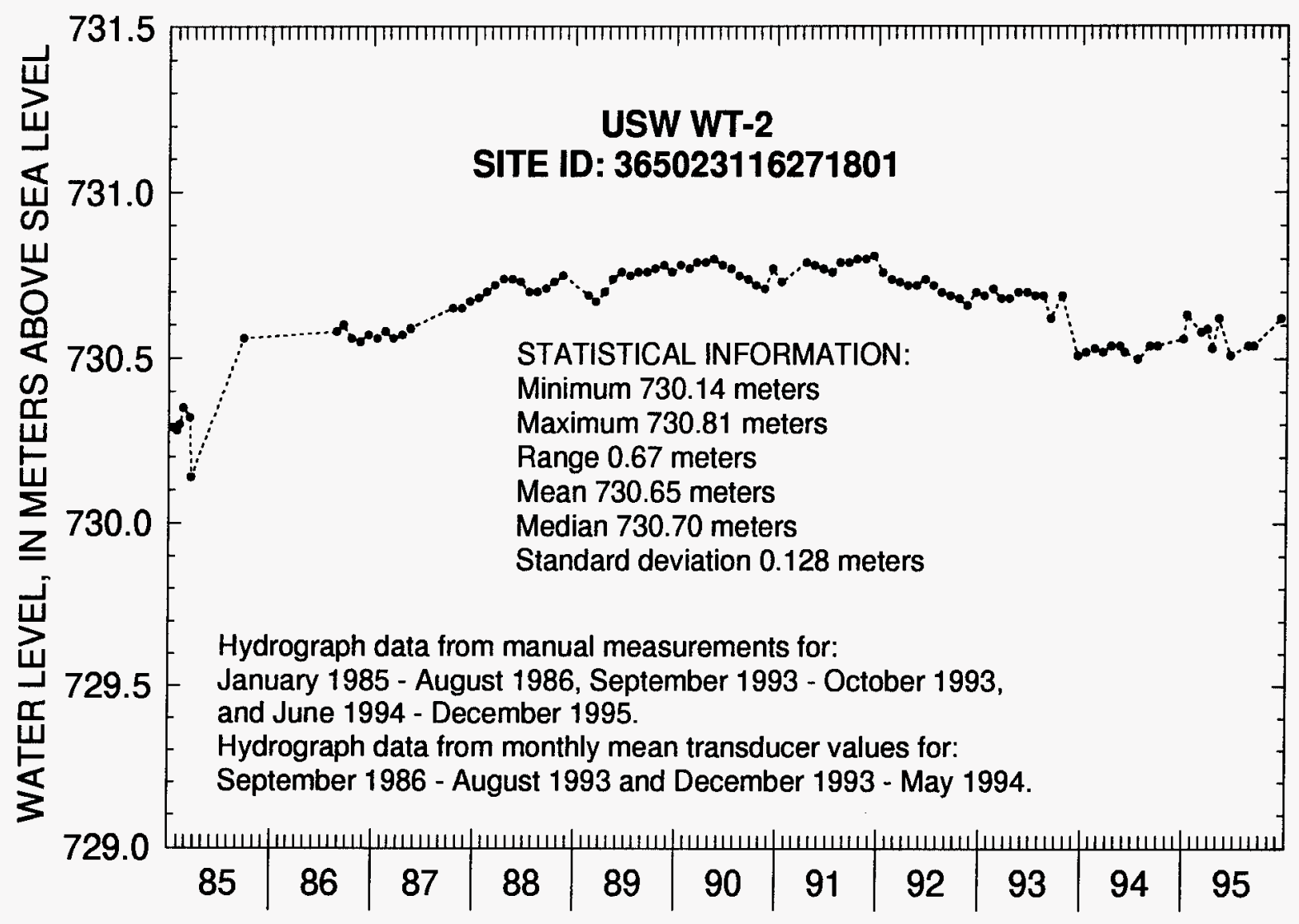

Figure 4. Water-level altitudes, 1985-95, for well USW WT-2.

\section{Well UE-25 WT\#3}

Water-level altitudes for well UE-25 WT\#3 ranged from 729.41 to $729.85 \mathrm{~m}$ above sea level from 1985-95 (fig. 5). The mean annual water-level altitude for $1985-95$ was $729.64 \mathrm{~m}$ above sea level. The median value was $729.70 \mathrm{~m}$. Standard deviation was $0.126 \mathrm{~m}$. The annual mean waterlevel altitudes for $1985-95$ are as follows:

\begin{tabular}{cc}
\hline Year & $\begin{array}{c}\text { Annual mean } \\
\text { water-level altitude } \\
\text { (meters) }\end{array}$ \\
\hline 1985 & 729.49 \\
1986 & 729.50 \\
1987 & 729.50 \\
1988 & 729.51 \\
1989 & 729.73 \\
1990 & 729.77 \\
1991 & 729.77 \\
1992 & 729.76 \\
1993 & 729.72 \\
1994 & 729.70 \\
1995 & 729.72 \\
\hline
\end{tabular}




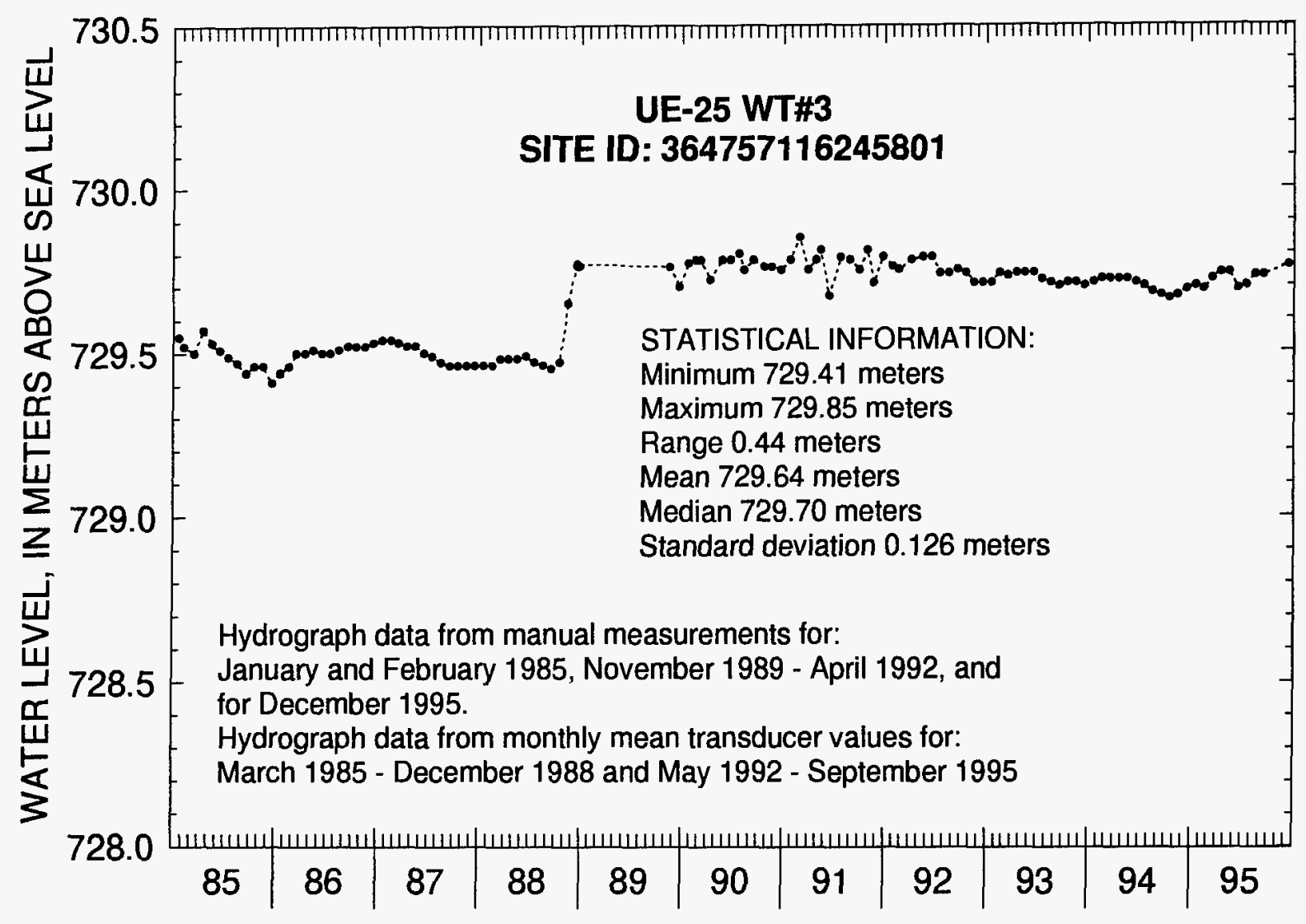

Figure 5. Water-level altitudes, 1985-95, for well UE-25 WT\#3.

Neither distinct seasonal trends in water-level changes or effects due to regional groundwater withdrawals were observed in well UE-25 WT\#3. Most changes in the water level can be attributed to barometric or Earth-tide changes. With the exception of a rapid rise in water level during November and December 1988, the water level in well UE-25 WT\#3 appears to be stable from January 1985 through June 1993, with no significant trends of rising or declining water levels. Although these stable conditions appear to dominate, it is believed that from 1985 through December 1988, there was a gradual rise in the water table, but this rise was not observed because of errors incurred with the calibration and converting of the transducer data.

From installation of transducer Serial Number 1950 on March 22, 1985, until its removal on December 13, 1988 (Luckey and others, 1993), the water levels in well UE-25 WT\#3 were made with a transducer tag on the water surface and not with a steel tape or single or multiconductor cable unit. The altitude of the manual water-level measurements made on March 22, 1985, and December 13,1988 , were 729.52 and $729.85 \mathrm{~m}$ respectively; a difference of $0.33 \mathrm{~m}$. The jump up in water level from the October 1988 monthly mean value of $729.47 \mathrm{~m}$ to the December 1988 monthly mean value of $729.77 \mathrm{~m}$ was $0.30 \mathrm{~m}$ (Appendix B). It could be that the slight increase in transducer output in millivolts between October and December 1988 was overly compensated to agree with the December 1988 manual water level. Whereas the true rise in water level over the 3-year period was more gradual.

Although slight, a gradual trend in water-level change is observed in well UE-25 WT\#3 beginning July 1993. From July 1993 through October 1994, there is a gradual decline in water level. This downward trend is followed by a rise in water level from November 1994 through December 1995. 


\section{Well UE-25 WT\#4}

Water-level altitudes for well UE-25 WT\#4 ranged from 730.28 to $731.17 \mathrm{~m}$ above sea level from 1985-95 (fig. 6). The mean annual water-level altitude for $1985-95$ was $730.78 \mathrm{~m}$ above sea level. The median value was $730.81 \mathrm{~m}$. Standard deviation was $0.118 \mathrm{~m}$. The annual mean waterlevel altitudes for $1985-95$ are as follows:

\begin{tabular}{cc}
\hline Year & $\begin{array}{c}\text { Annual mean } \\
\text { water-level altitude } \\
\text { (meters) }\end{array}$ \\
\hline 1985 & 730.58 \\
1986 & 730.76 \\
1987 & 730.78 \\
1988 & 730.69 \\
1989 & 730.83 \\
1990 & 730.87 \\
1991 & 730.88 \\
1992 & 730.90 \\
1993 & 730.82 \\
1994 & 730.79 \\
1995 & 730.81 \\
\hline
\end{tabular}

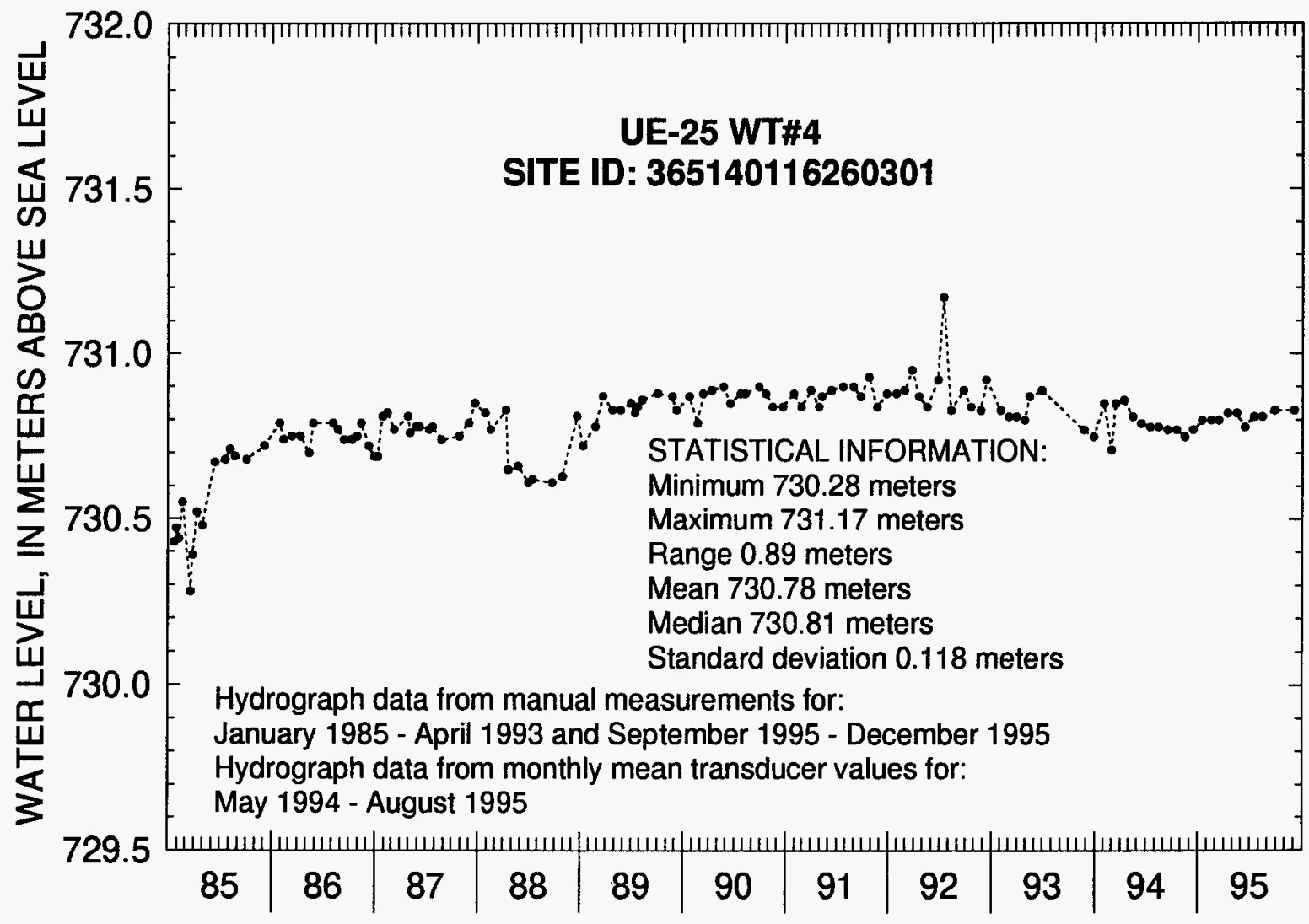

Figure 6. Water-level altitudes, 1985-95, for well UE-25 WT\#4. 
Neither distinct seasonal trends in water-level changes or effects due to regional ground-water withdrawals were observed in well UE-25 WT\#4; however, the effects of pumpage from the well for waterquality sampling were observed. From April 11 through 18, 1988, about 3,000 L of ground water were pumped from the well. As a result, subsequent water-level measurements for 1988 reflected residual effects from this pumping (Gemmell, 1990). Also, the effects of nearby earthquakes, which occurred in the region during June 28-29, 1992 (O'Brien, 1993), can be seen in the abrupt rise in water level during July 1992. With the exception of these two known occurrences, most water-level changes are attributed to barometric or Earth-tide changes.

Over the 11 years of record, there is a rise in water level from January 1985, through the earthquakeinduced water level of July 1992, followed by a gradual decline in water level through December 1995. Without the collection of continuous water-level data, it is not known if the decline in water level is directly related to the earthquake activity or is just following a long-term trend as seen in other wells.

\section{Well UE-25 WT\#6}

Water-level altitudes for well UE-25 WT\#6 ranged from 1033.29 to $1036.09 \mathrm{~m}$ above sea level from 1985-95 (fig. 7). The mean annual water-level altitude for 1985-95 was 1,034.60 m above sea level. The median value was $1,034.52 \mathrm{~m}$. Standard deviation was $0.553 \mathrm{~m}$. The annual mean water-level altitudes for 1985-95 are as follows:

\begin{tabular}{cc}
\hline Year & $\begin{array}{c}\text { Annual mean } \\
\text { water-level altitude } \\
\text { (meters) }\end{array}$ \\
\hline 1985 & $1,033.79$ \\
1986 & $1,034.06$ \\
1987 & $1,034.36$ \\
1988 & $1,035.10$ \\
1989 & $1,035.21$ \\
1990 & $1,035.21$ \\
1991 & $1,035.16$ \\
1992 & $1,034.75$ \\
1993 & $1,034.35$ \\
1994 & $1,034.49$ \\
1995 & $1,034.49$ \\
\hline
\end{tabular}

Since completion of well UE-25 WT\#6 in 1983 through March 1990, the water level in the well has been rising. Robison and others (1988) reported that the water level in the well rose $8 \mathrm{~m}$ in the first 2 months after the well was drilled. Robison suggested that the reason for this steady rise in water level was because of the low permeability of the rocks (Calico Hills Formation) that were penetrated below the water table.

After March 1990, there appears to be a general decline in water level until right after the earthquakes that occurred in the region during June 28-29, 1992 (O'Brien, 1993; O'Brien and others, 1995). Following the earthquakes, the water level in the well rose rapidly and then declined sharply to a lower water level than before the event. Following a low of 1,034.22 m during November 1992, the water level in well UE-25 WT\#6 has gradually been rising through December 1995. 


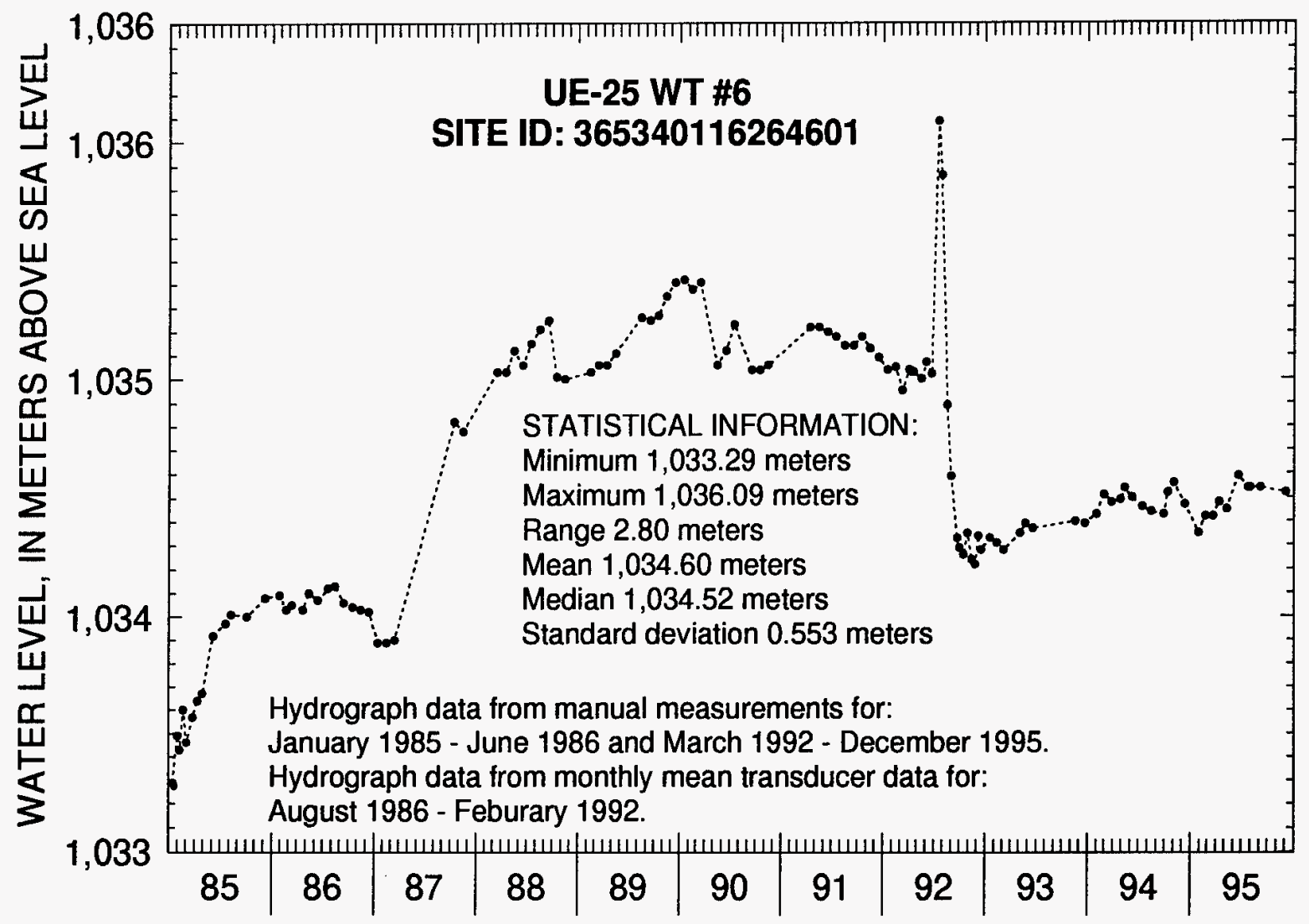

Figure 7. Water-level altitudes, 1985-95, for well UE-25 WT\#6.

\section{Well USW WT-7}

Water-level altitudes for well USW WT-7 ranged from 775.47 to $775.99 \mathrm{~m}$ above sea level from 1985-95 (fig. 8). The mean annual water-level altitude for 1985-95 was $775.83 \mathrm{~m}$ above sea level. The median value was $775.85 \mathrm{~m}$. Standard deviation was $0.096 \mathrm{~m}$. The annual mean waterlevel altitudes for 1985-95 are as follows:

\begin{tabular}{cc}
\hline Year & $\begin{array}{c}\text { Annual mean } \\
\text { water-level altitude } \\
\text { (meters) }\end{array}$ \\
\hline 1985 & 775.68 \\
1986 & 775.78 \\
1987 & 775.80 \\
1988 & 775.71 \\
1989 & 775.83 \\
1990 & 775.86 \\
1991 & 775.87 \\
1992 & 775.89 \\
1993 & 775.88 \\
1994 & 775.88 \\
1995 & 775.93 \\
\hline
\end{tabular}


Neither distinct seasonal trends in water-level changes or effects due to regional ground-water withdrawals were observed in well USW WT-7. On June 6, 1988, $760 \mathrm{~L}$ were pumped from the well for water-quality sampling (Gemmell, 1990). The effects on the water level in the well due to this pumpage were negligible, with the well recovering to prepumping conditions within 17 days of pumpage (Appendix B). Over the 11 years of record, there is an initial rise in water level from January through December 1985, followed by a gradual decline in the water level from January 1986 through July 1988, and then another rise in water level from August 1988 through December 1995. Most changes within these long-term trends can be attributed to barometric or Earth-tide changes. To determine if the longterm trends observed in this well are cyclic, continuous long-term water-level data need to be collected.

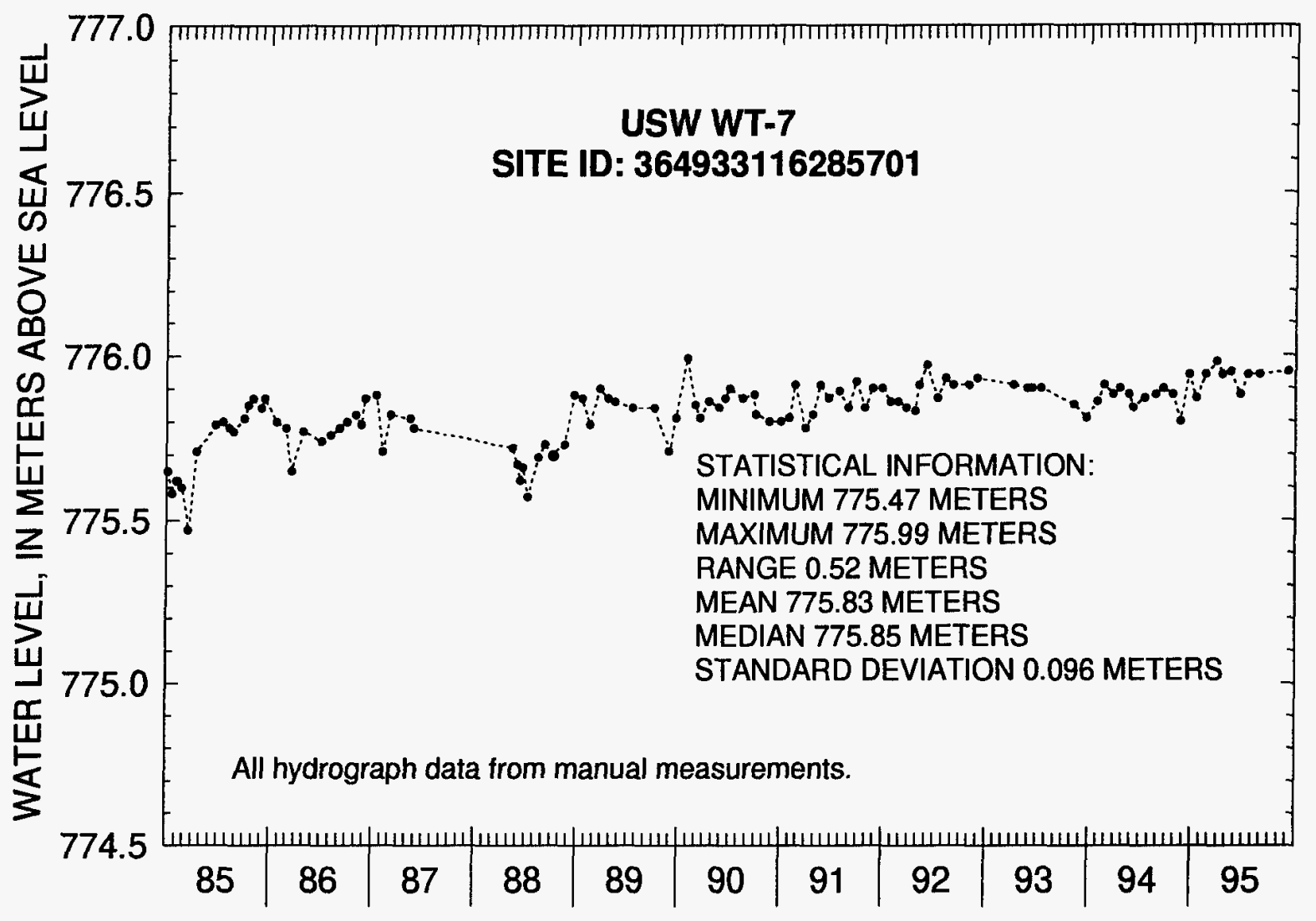

Figure 8. Water-level altitudes, 1985-95, for well USW WT-7.

\section{Well USW WT-10}

Water-level altitudes for well USW WT-10 ranged from 775.56 to $776.21 \mathrm{~m}$ above sea level from 1985-95 (fig. 9). The mean annual water-level altitude for $1985-95$ was $776.00 \mathrm{~m}$ above sea level. The median value was also $776.00 \mathrm{~m}$. Standard deviation was $0.114 \mathrm{~m}$. The annual mean water-level altitudes for 1985-95 are as follows: 


\begin{tabular}{cc}
\hline Year & $\begin{array}{c}\text { Annual mean } \\
\text { water-level altitude } \\
\text { (meters) }\end{array}$ \\
\hline 1985 & 775.92 \\
1986 & 775.84 \\
1987 & 775.94 \\
1988 & 775.92 \\
1989 & 775.98 \\
1990 & 776.00 \\
1991 & 776.01 \\
1992 & 776.04 \\
1993 & 776.11 \\
1994 & 776.13 \\
1995 & 776.10 \\
\hline
\end{tabular}

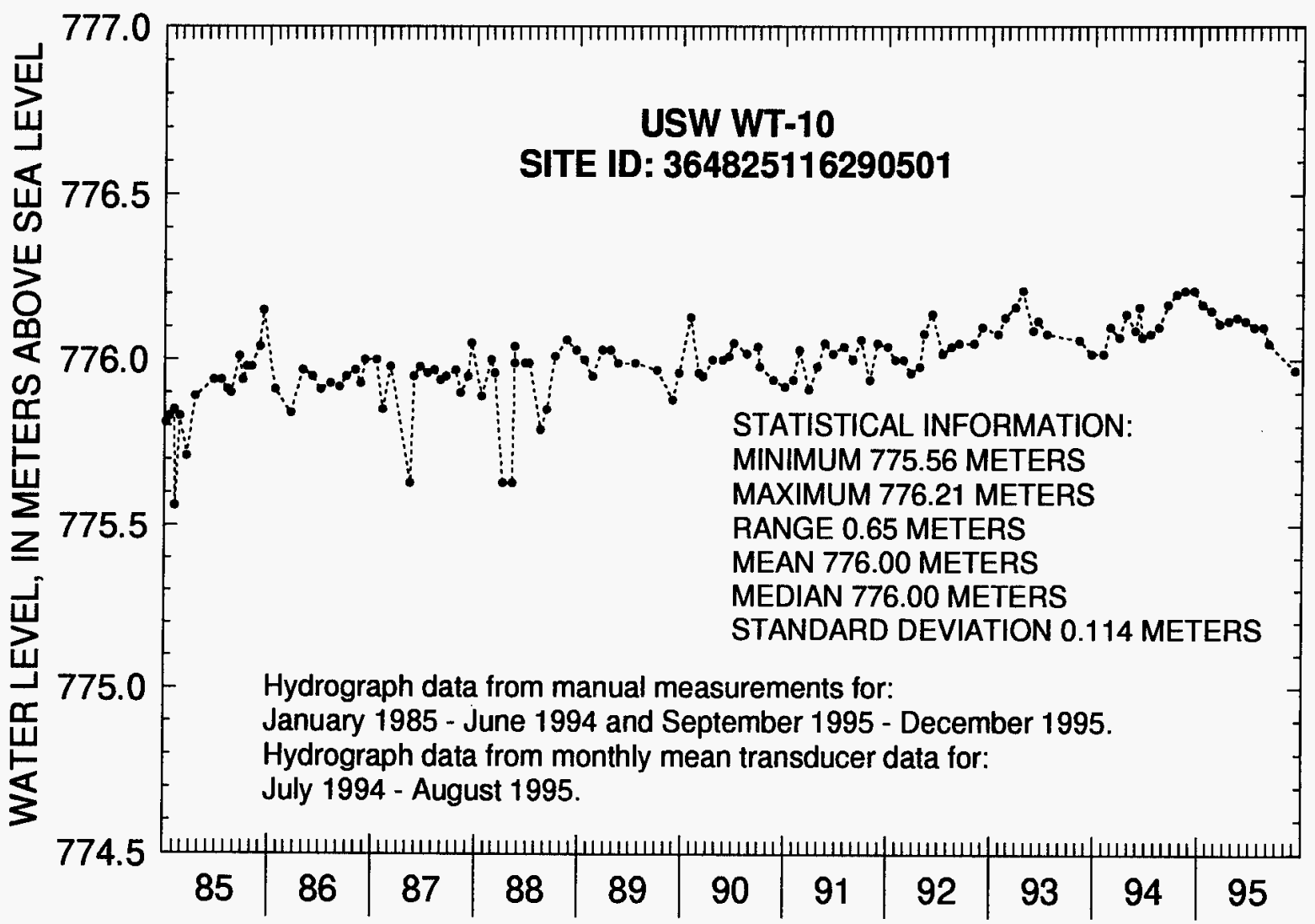

Figure 9. Water-level altitudes, 1985-95, for well USW WT-10.

Neither distinct seasonal trends in water-level changes or effects due to regional ground-water withdrawals were observed in well USW WT-10. Most changes in the water level can be attributed to barometric or Earth-tide changes. Over the 11 years of record, there is a gradual rise in the water level from 1985-95. 
Some anomalies could be present in the water-level data for well USW WT-10. Robison and others (1988) and Gemmell (1990) report water-level measurements that were approximately $1 \mathrm{ft}$ off the yearly trends (Robison discussed anomalies in 1985 data and Gemmell anomalies in 1987 and 1988 data). They both suggest that since the water-level data is collected in feet, an error of $1 \mathrm{ft}$ could have been made in reading the steel tape used to make the measurement. This explanation could explain the low water levels measured on February 6, 1985, May 14, 1987, April 5, 1988, and May 9, 1988 (Appendix B). Gemmell also reports that 12,000 L of ground water were pumped from well USW WT-10 for water-quality sampling between May 9 and 16, 1988. It would be expected that pumpage of the well would lower the water level in the well, and that might explain the lower water level of May 9, 1988. However, the measurement made on May 9, 1988, was made before the well was pumped. Subsequently, it is assumed that each of the aforementioned water levels could be in error.

\section{Well USW WT-11}

Water-level altitudes for well USW WT-11 ranged from 730.21 to $730.81 \mathrm{~m}$ above sea level from 1985-95 (fig. 10). The mean annual water-level altitude for 1985-95 was $730.66 \mathrm{~m}$ above sea level. The median value was $730.69 \mathrm{~m}$. Standard deviation was $0.099 \mathrm{~m}$. The annual mean water-level altitudes for $1985-95$ are as follows:

\begin{tabular}{ll}
\hline Year & $\begin{array}{c}\text { Annual mean } \\
\text { water-lovel altitude } \\
\text { (meters) }\end{array}$ \\
\hline 1985 & 730.52 \\
1986 & 730.60 \\
1987 & 730.72 \\
1988 & 730.72 \\
1989 & 730.71 \\
1990 & 730.71 \\
1991 & 730.71 \\
1992 & 730.67 \\
1993 & 730.69 \\
1994 & 730.66 \\
1995 & 730.68 \\
\hline
\end{tabular}

Neither distinct seasonal trends in water-level changes or effects due to regional ground-water withdrawals were observed in well USW WT-11. Most changes in the water level can be attributed to barometric or Earth-tide changes. Over the 11 years of record, there is a general rise in the water level from January 1985 through November 1988, followed by a gradual decline in water-level from March 1988 through December 1995.

The water level in well USW WT-11 could have been affected by the earthquakes of June 28 and 29, 1992. For five months following the earthquake (July through November 1992), a distinct decline in the water level, which is considered outside of the long-term trend, can be seen. This decline in water level is followed by a rise in water level until May 1993, when the water level returns to levels consistent with those prior to the earthquake. Whether this is coincidental or not is not known. To determine if this decline in water level or the long-term trends occurring in the well are repeatable, long-term continuous data need to be collected. 


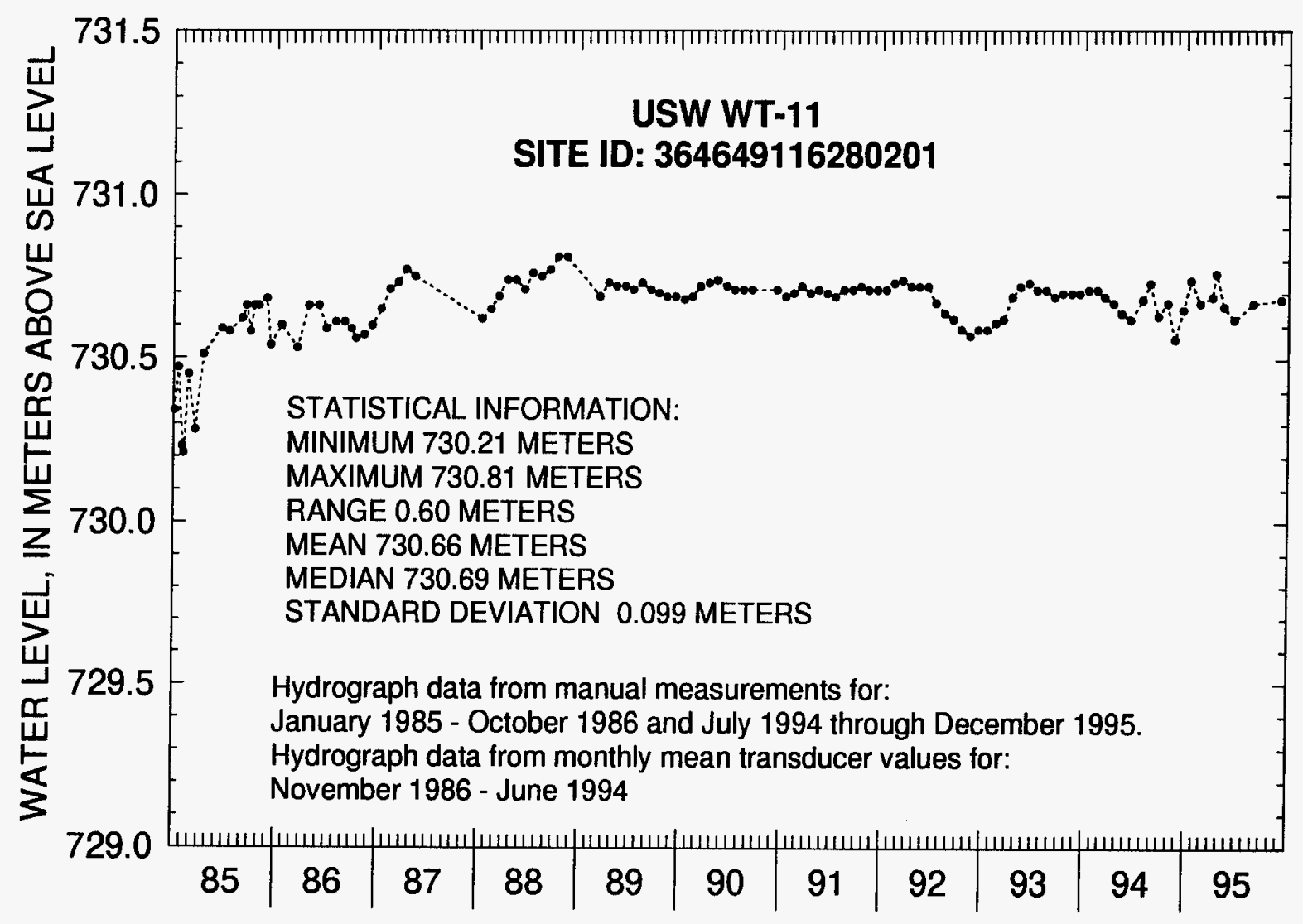

Figure 10. Water-level altitudes, 1985-95, for well USW WT-11.

\section{Well UE-25 WT\#12}

Water-level altitudes for well UE-25 WT\#12 ranged from 729.11 to $729.58 \mathrm{~m}$ above sea level from 1985-95 (fig. 11). The mean annual water-level altitude for $1985-95$ was $729.47 \mathrm{~m}$ above sea level. The median value was $729.48 \mathrm{~m}$. Standard deviation was $0.074 \mathrm{~m}$. The annual mean water-level altitudes for $1985-95$ are as follows:

\begin{tabular}{cc}
\hline Year & $\begin{array}{c}\text { Annual mean } \\
\text { water-level altitude } \\
\text { (meters) }\end{array}$ \\
\hline 1985 & 729.37 \\
1986 & 729.46 \\
1987 & 729.50 \\
1988 & 729.52 \\
1989 & 729.49 \\
1990 & 729.52 \\
1991 & 729.53 \\
1992 & 729.50 \\
1993 & 729.42 \\
1994 & 729.44 \\
1995 & 729.44 \\
\hline
\end{tabular}




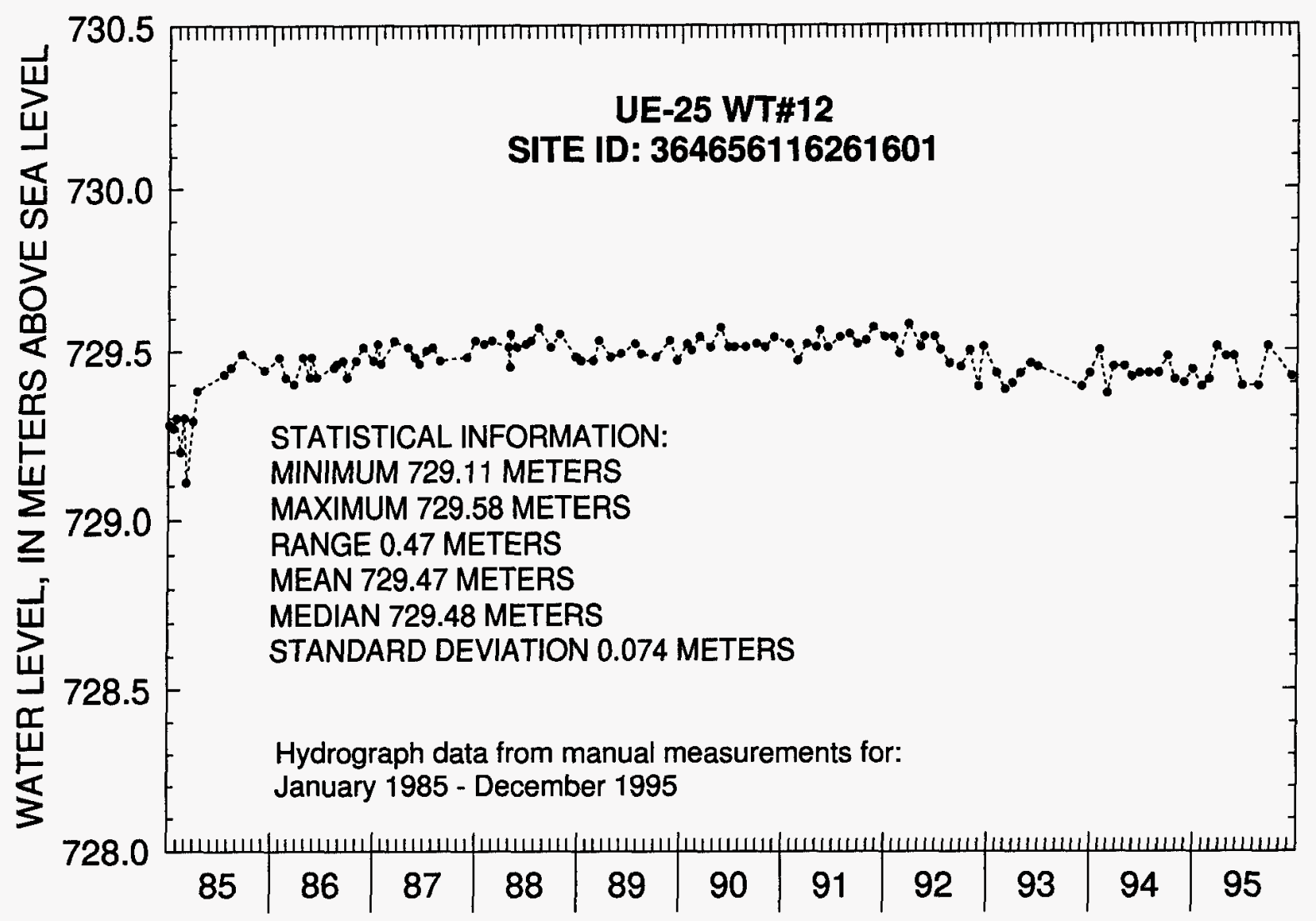

Figure 11. Water-level altitudes, 1985-95, for well UE-25 WT\#12.

Neither distinct seasonal trends in water-level changes or effects due to regional ground-water withdrawals were observed in well UE-25 WT\#12. Most changes in the water level can be attributed to barometric or Earth-tide changes. Over the 11 years of record, there is a rise in water level from January 1985 through about June 1992, followed by an overall decline in water level from July 1995 through December 1995. This trend toward a declining water level occurred after a series of regional earthquakes took place between June 28-29, 1992 (O'Brien, 1993). To determine whether this is coincidental or may follow a pattern of water-level change in wells following nearby seismic activity, continuous long-term waterlevel data need to be collected.

Gemmell (1990) reported that from April 25 to May 2, 1988, 9,500 L of ground water were pumped from well UE-25 WT\#12 for water-quality sampling. The effect of this pumpage can be seen in the May 2, 1988, water level. The water level measured after the pump was turned off was about $0.06 \mathrm{~m}$ lower than the prepumping water level (Appendix B). The water-level measurement made in the well on May 3, 1988, indicated that the well had fully recovered 1 day following discontinuation of pumpage.

From August 19, 1995, through September 15, 1995, a series of single-well aquifer tests were conducted at well UE-25 WT\#12 and approximately $1,600 \mathrm{~m}^{3}$ of ground water was pumped from the well (Grady O'Brien, U.S. Geological Survey, oral commun., 1996). Observations made during the series of tests indicated that within 1 hour of turning the pump off at the conclusion of each test, the water level in the well had fully recovered to static conditions. Comparison of the water levels in the well before and after the tests (Appendix B) shows that there was an overall rising trend in the water level of $0.12 \mathrm{~m}$ from 2 days before the tests began to 4 days after the tests ended. 


\section{Well UE-25 WT\#13}

Water-level altitudes for well UE-25 WT\#13 ranged from 728.53 to $729.43 \mathrm{~m}$ above sea level from 1985-95 (fig. 12). The mean annual water-level altitude for 1985-95 was $729.11 \mathrm{~m}$ above sea level. The median value was $729.14 \mathrm{~m}$. Standard deviation was $0.119 \mathrm{~m}$. The annual mean water-level altitudes for 1985-95 are as follows:

\begin{tabular}{ll}
\hline Year & $\begin{array}{c}\text { Annual mean } \\
\text { water-level altitude } \\
\text { (meters) }\end{array}$ \\
\hline 1985 & 729.09 \\
1986 & 729.11 \\
1987 & 729.13 \\
1988 & 728.98 \\
1989 & 729.02 \\
1990 & 729.17 \\
1991 & 729.14 \\
1992 & 729.13 \\
1993 & 729.11 \\
1994 & 729.17 \\
1995 & 729.18 \\
\hline
\end{tabular}

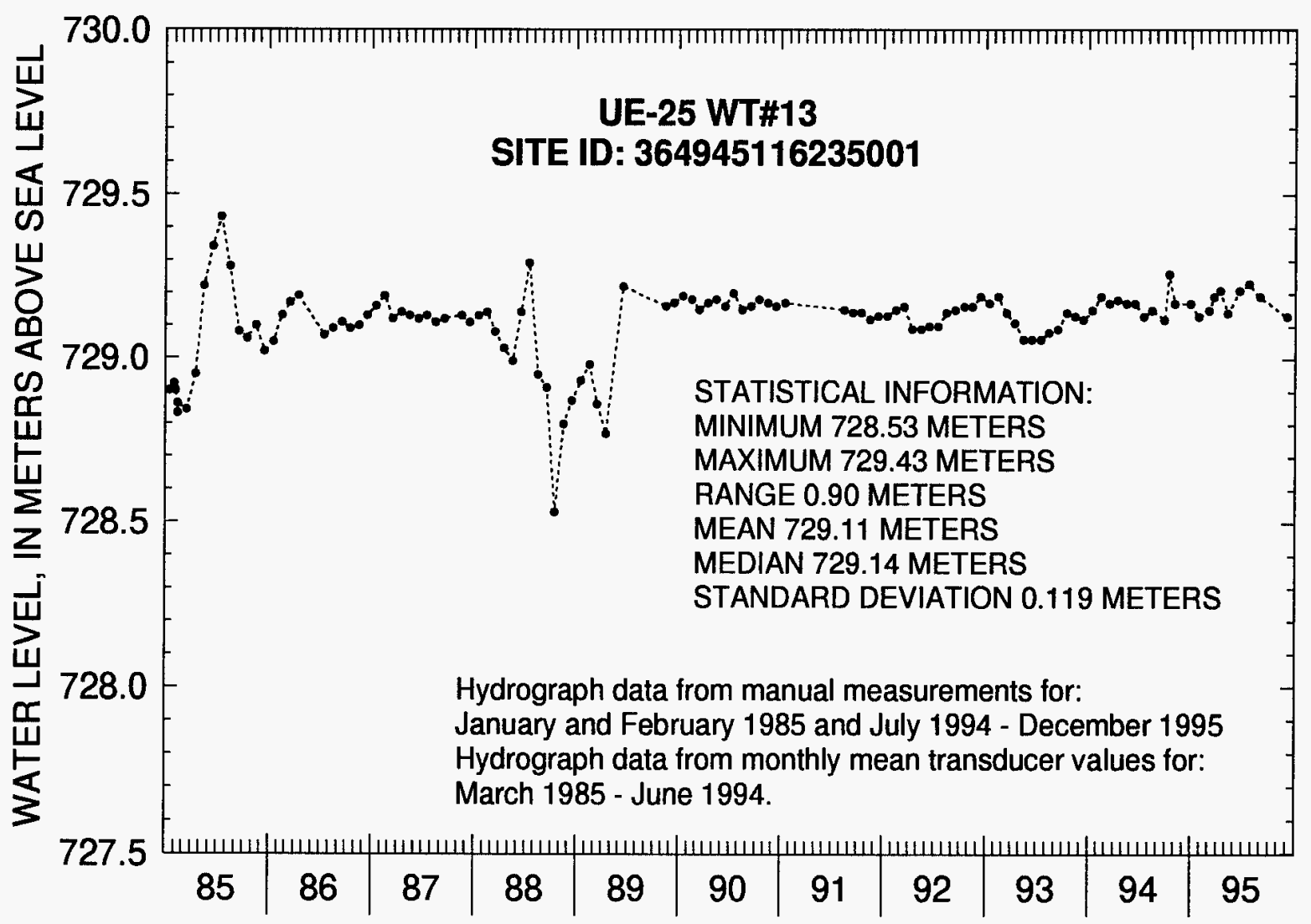

Figure 12. Water-level altitudes, 1985-95, for well UE-25 WT\#13. 
Neither distinct seasonal trends in water-level changes or effects due to regional ground-water withdrawals were observed in well UE-25 WT\#13. With the exception of several sharp changes in the water table during 1985 and from June 1988 through June 1989, most changes in the water level can be attributed to barometric or Earth-tide changes. Changes during these specified periods might be attributed to transducer error. During 1985, from February 12 through September 25, two transducers were used in the well (Luckey and others, 1993). During 1988 and 1989, from August 1988 through December 1989, three transducers were used (Luckey and others, 1993; Lobmeyer and others, 1995). Because the transducer is often used to determine depth to water by tagging the water table, several calibrations may be completed at the well before transducer malfunction is detected. These water-level tags may not have a large enough error to reflect a bad transducer, but there could be enough error to significantly change the water-level trend away from its normal plot. These errors will not be realized until the transducer is removed and a manual water-level measurement made. When this is done, the water-level data can be corrected back to the last calibration; however, beyond that, with the exception of deleting data, nothing can be done to the previously collected water levels. With the exception of the 1985 and 1988-89 data, the water table in well UE-25 WT\#13 is virtually stable, with no distinct rising or declining trends from 1985-95.

\section{Well UE-25 WT\#14}

Water-level altitudes for well UE-25 WT\#14 ranged from 729.29 to $729.98 \mathrm{~m}$ above sea level from 1985-95 (fig. 13). The mean annual water-level altitude for 1985-95 was $729.68 \mathrm{~m}$ above sea level. The median value was $729.69 \mathrm{~m}$. Standard deviation was $0.073 \mathrm{~m}$. The annual mean water-level altitudes for $1985-95$ are as follows:

\begin{tabular}{ll}
\hline Year & $\begin{array}{c}\text { Annual mean } \\
\text { water-level altitude } \\
\text { (meters) }\end{array}$ \\
\hline 1985 & 729.56 \\
1986 & 729.68 \\
1987 & 729.71 \\
1988 & 729.71 \\
1989 & 729.72 \\
1990 & 729.72 \\
1991 & 729.74 \\
1992 & 729.72 \\
1993 & 729.66 \\
1994 & 729.63 \\
1995 & 729.65 \\
\hline
\end{tabular}

Neither distinct seasonal trends in water-level changes or effects due to regional ground-water withdrawals were observed in well UE-25 WT\#14. Most changes in the water level can be attributed to barometric or Earth-tide changes. Over the 11 years of record, there is a very slight rise in water level from January 1985 through June 1991, followed by a very slight decline in the water level from July 1991 through December 1995. Without the collection of continuous long-term water-level data, it is not known if more distinct and definite trends in well UE-25 WT\#14 might develop.

Some anomalies could be present in the water-level data for well UE-25 WT\#14. Robison and others (1988) reported that the water-level measurements made for March 20, 1985, and May 5, 1987, are approximately $1 \mathrm{ft}$ off the 1985 and 1987 yearly trends (Appendix B). Robison and others (1988) further indicate that because of the measurement process (which measures water-levels in feet) unverifiable 
onsite recording errors, when they occur, are more likely to be in multiples of feet; therefore, these two water-level measurements might not be accurate.

Gemmell (1990) reported that from March 22 through 26, 1988, 9,200 L of ground water were pumped from well UE-25 WT\#14 for water-quality sampling. The effect of this pumpage on the water level was negligible. Comparing water-level measurements from the day before pumping began to 9 days following the completion of pumping indicates only a $0.03-\mathrm{m}$ difference (Appendix B). This difference is in the range of monthly change, subsequently it can be assumed that well UE-25 WT\#14 recovered reasonably quickly following completion of pumping the well.

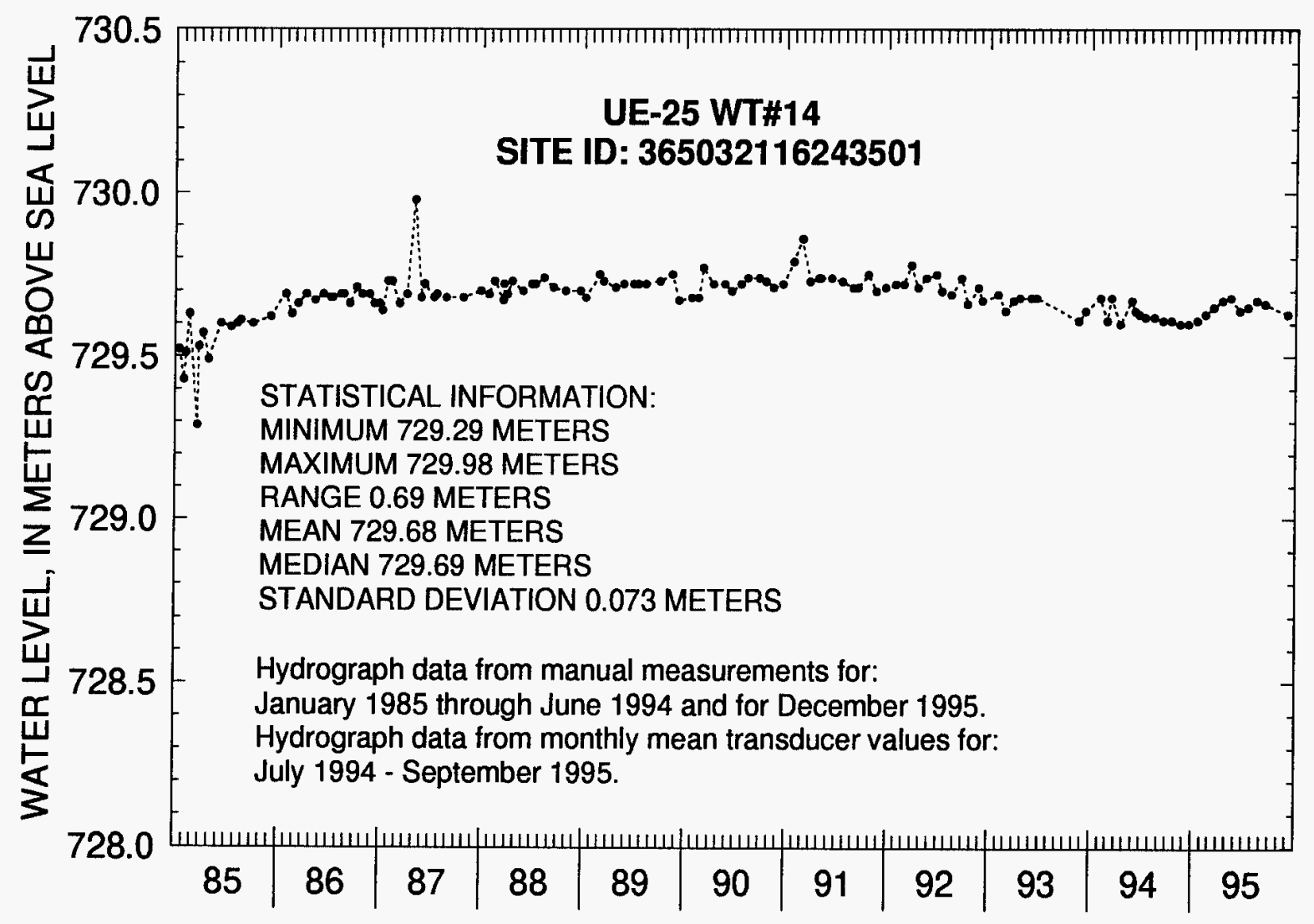

Figure 13. Water-level altitudes, 1985-95, for well UE-25 WT\#14.

\section{Well UE-25 WT\#15}

Water-level altitudes for well UE-25 WT\#15 ranged from 728.98 to $729.42 \mathrm{~m}$ above sea level from 1985-95 (fig. 14). The mean annual water-level altitude for $1985-95$ was $729.22 \mathrm{~m}$ above sea level. The median value was also $729.22 \mathrm{~m}$. Standard deviation was $0.070 \mathrm{~m}$. The annual mean water-level altitudes for 1985-95 are as follows: 


\begin{tabular}{cc}
\hline Year & $\begin{array}{c}\text { Annual mean } \\
\text { water-level altitude } \\
\text { (meters) }\end{array}$ \\
\hline 1985 & 729.17 \\
1986 & 729.23 \\
1987 & 729.22 \\
1988 & 729.24 \\
1989 & 729.24 \\
1990 & 729.25 \\
1991 & 729.26 \\
1992 & 729.23 \\
1993 & 729.21 \\
1994 & 729.19 \\
1995 & 729.27 \\
\hline
\end{tabular}

Neither distinct seasonal trends in water-level changes or effects due to regional ground-water withdrawals were observed in well UE-25 WT\#15. Most changes in the water-level can be attributed to barometric or Earth-tide changes. Over the 11 years of record, the water table in well UE-25 WT\#15 was stable, with no distinct rising or declining trends.

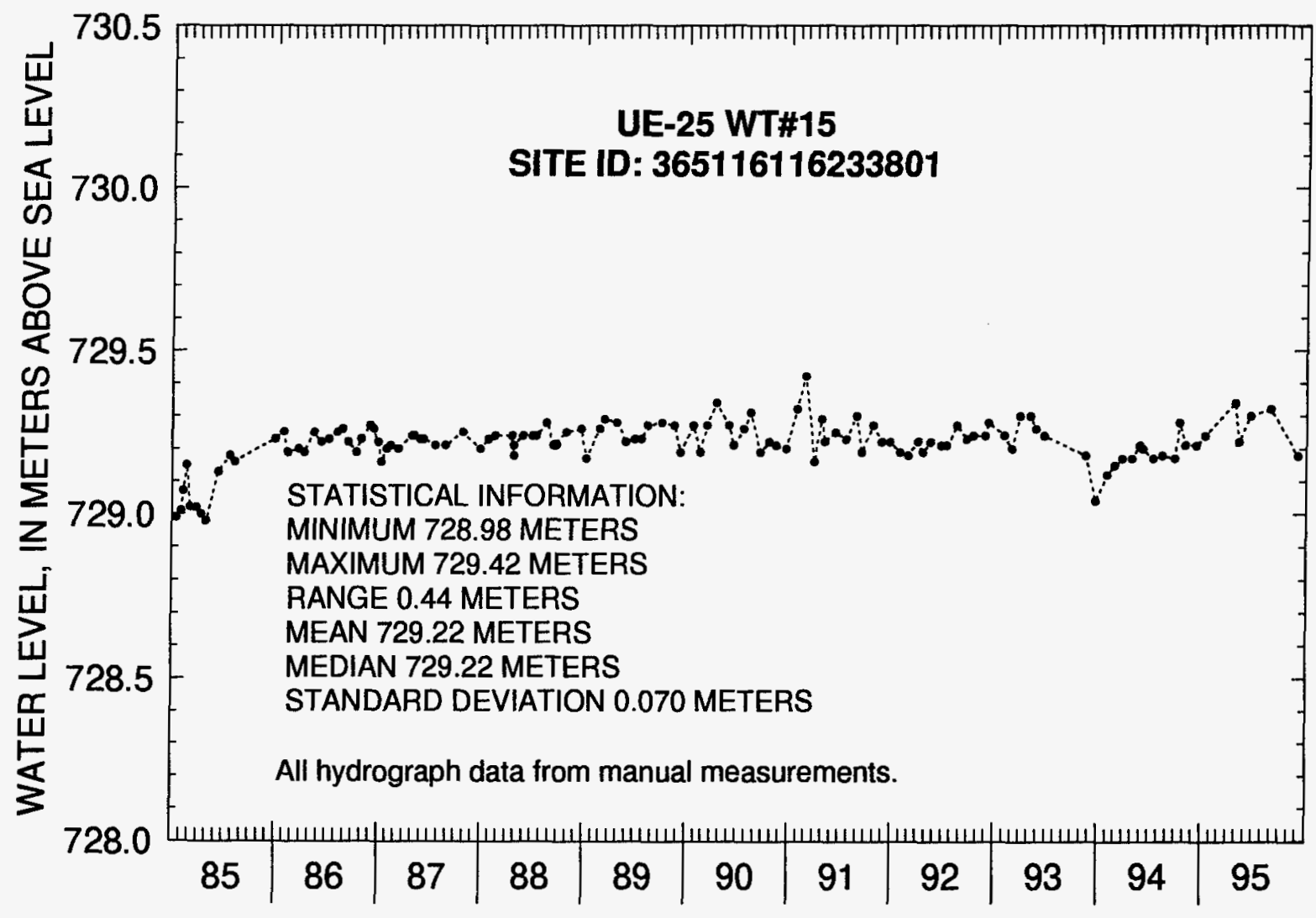

Figure 14. Water-level altitudes, 1985-95, for well UE-25 WT\#15. 


\section{Well UE-25 WT\#16}

Water-level altitudes for well UE-25 WT\#16 ranged from 737.82 to $738.57 \mathrm{~m}$ above sea level from 1985-95 (fig. 15). The mean annual water-level altitude for $1985-95$ was $738.27 \mathrm{~m}$ above sea level. The median value was $738.29 \mathrm{~m}$. Standard deviation was $0.147 \mathrm{~m}$. The annual mean water-level altitudes for $1985-95$ are as follows:

\begin{tabular}{ll}
\hline Year & $\begin{array}{c}\text { Annual mean } \\
\text { water-level altitude } \\
\text { (meters) }\end{array}$ \\
\hline 1985 & 738.00 \\
1986 & 738.16 \\
1987 & 738.15 \\
1988 & 738.31 \\
1989 & 738.37 \\
1990 & 738.35 \\
1991 & 738.42 \\
1992 & 738.34 \\
1993 & 738.28 \\
1994 & 738.35 \\
1995 & 738.30 \\
\hline
\end{tabular}

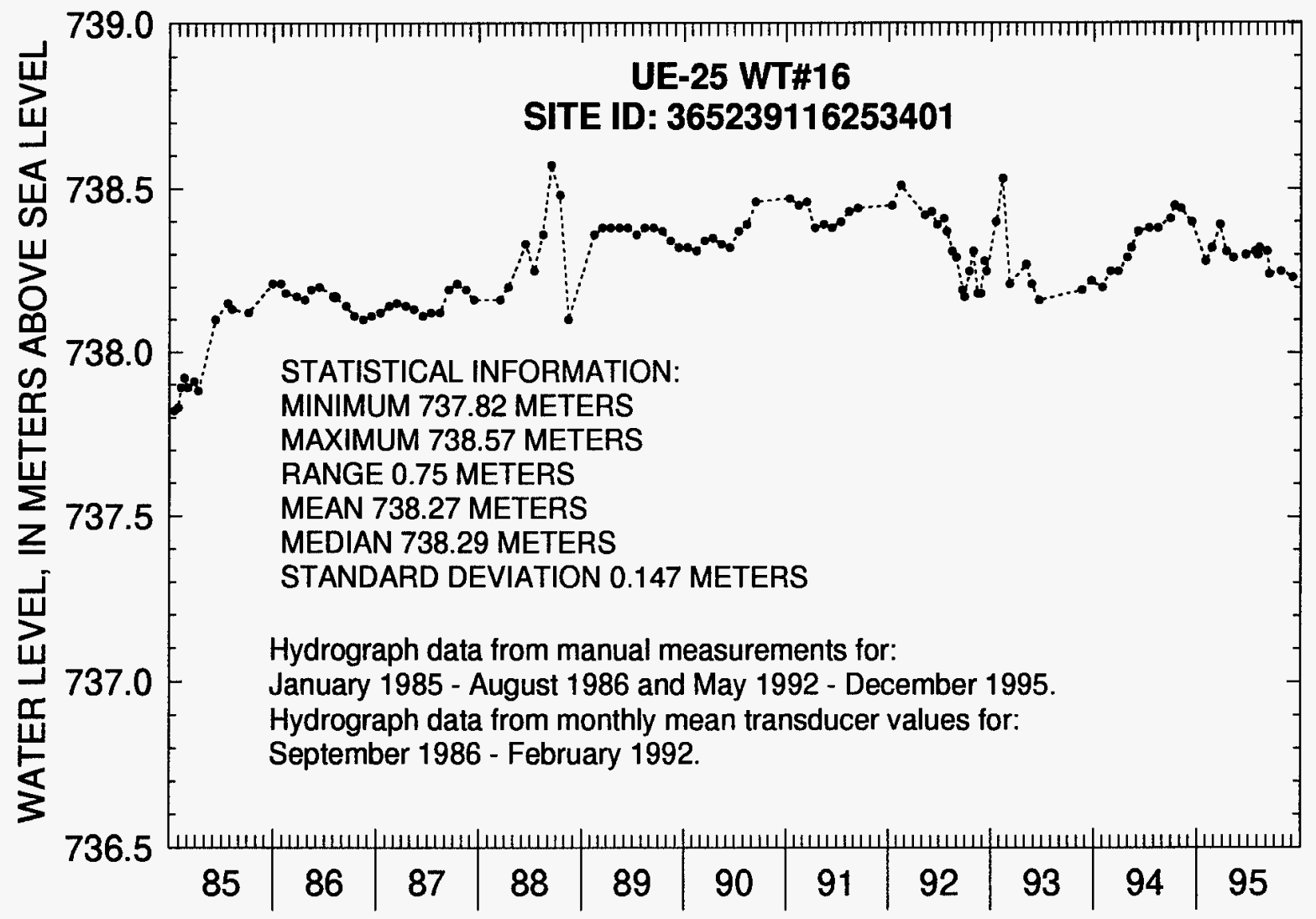

Flgure 15. Water-level altitudes, 1985-95, for well UE-25 WT\#16. 
Neither distinct seasonal trends in water-level changes or effects due to regional ground-water withdrawals were observed in well UE-25 WT\#16. Most changes in the water level can be attributed to barometric and Earth-tide changes. Over the 11 years of record, there is a gradual rise in water-level from January 1985 through May 1992, followed by an overall decline in water level from June 1992 through December 1995.

Following the regional earthquakes of June 28-29, 1992 (O'Brien, 1993), there was a minor rise in the water level during July followed by an apparent accelerated decline in the water level through October 1992. To determine if this water-level change is due to the occurrence of the earthquake or just due to cyclic patterns in the well, continuous long-term water-level data need to be collected.

\section{Well UE-25 WT\#17}

Water-level altitudes for well UE-25 WT\#17 ranged from 729.45 to $729.84 \mathrm{~m}$ above sea level from 1985-95 (fig. 16). The mean annual water-level altitude for $1985-95$ was $729.70 \mathrm{~m}$ above sea level. The median value was $729.72 \mathrm{~m}$. Standard deviation was $0.083 \mathrm{~m}$. The annual mean water-level altitudes for 1985-95 are as follows:

\begin{tabular}{cc}
\hline Year & $\begin{array}{c}\text { Annual mean } \\
\text { water-level altitude } \\
\text { (meters) }\end{array}$ \\
\hline 1985 & 729.57 \\
1986 & 729.71 \\
1987 & 729.71 \\
1988 & 729.65 \\
1989 & 729.77 \\
1990 & 729.76 \\
1991 & 729.78 \\
1992 & 729.74 \\
1993 & 729.69 \\
1994 & 729.63 \\
1995 & 729.68 \\
\hline
\end{tabular}

Neither distinct seasonal trends in water-level changes or effects due to regional ground-water withdrawals were observed in well UE-25 WT\#17. Most changes in the water level can be attributed to barometric and Earth-tide changes. Over the 11 years of record, there is a gradual rise in water-level from January 1985 through May 1992, followed by a decline in water-level from June 1992 through December 1995. To determine if this is a cyclic pattern, continuous long-term water-level data need to be collected. 


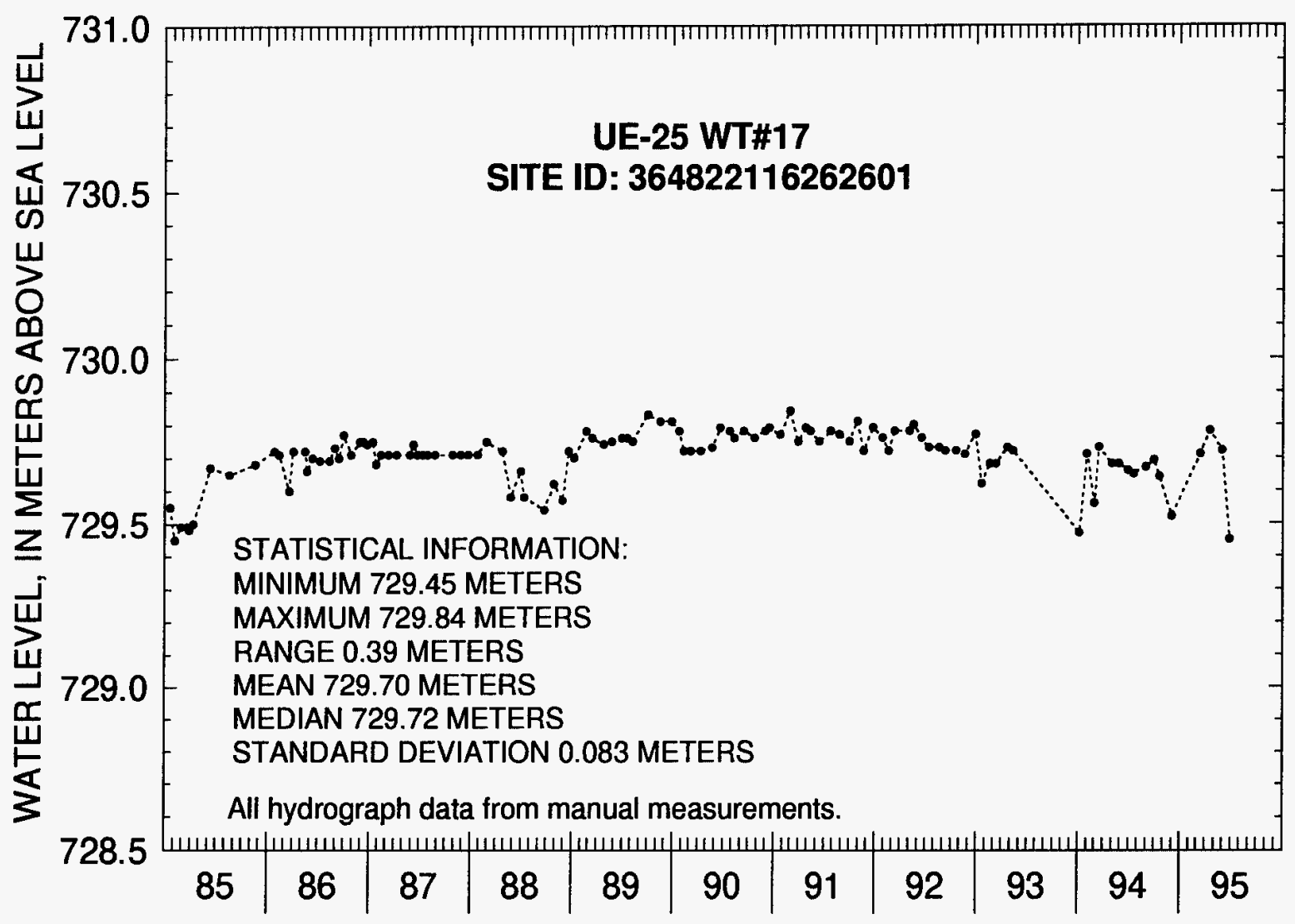

Flgure 16. Water-level altitudes, 1985-95, for well UE-25 WT\#17.

\section{Well UE-25 WT\#18}

Water-level altitude data are not available for well UE-25 WT\#18 from 1985-90. For 1991-95, water-level altitudes for well UE-25 WT\#18 ranged from 730.52 to $730.92 \mathrm{~m}$ above sea level (fig. 17). The mean annual water-level altitude for $1991-95$ was $730.75 \mathrm{~m}$ above sea level. The median value was $730.76 \mathrm{~m}$. Standard deviation was $0.095 \mathrm{~m}$. The annual mean water-level altitudes for 1991-95 are as follows:

\begin{tabular}{cc}
\hline Year & $\begin{array}{c}\text { Annual mean } \\
\text { water-level altitude } \\
\text { (meters) }\end{array}$ \\
\hline 1985 & Data not available \\
1986 & Data not available \\
1987 & Data not available \\
1988 & Data not available \\
1989 & Data not available \\
1990 & Data not available \\
1991 & 730.83 \\
1992 & 730.83 \\
1993 & 730.77 \\
1994 & 730.70 \\
1995 & 730.59 \\
\hline
\end{tabular}


Neither distinct seasonal trends in water-level changes or effects due to regional ground-water withdrawals were observed in well UE-25 WT\#18. Most changes in the water level can be attributed to barometric and Earth-tide changes. Over the 5 years of available record, there is a decline in water level from November 1991 through August 1995.

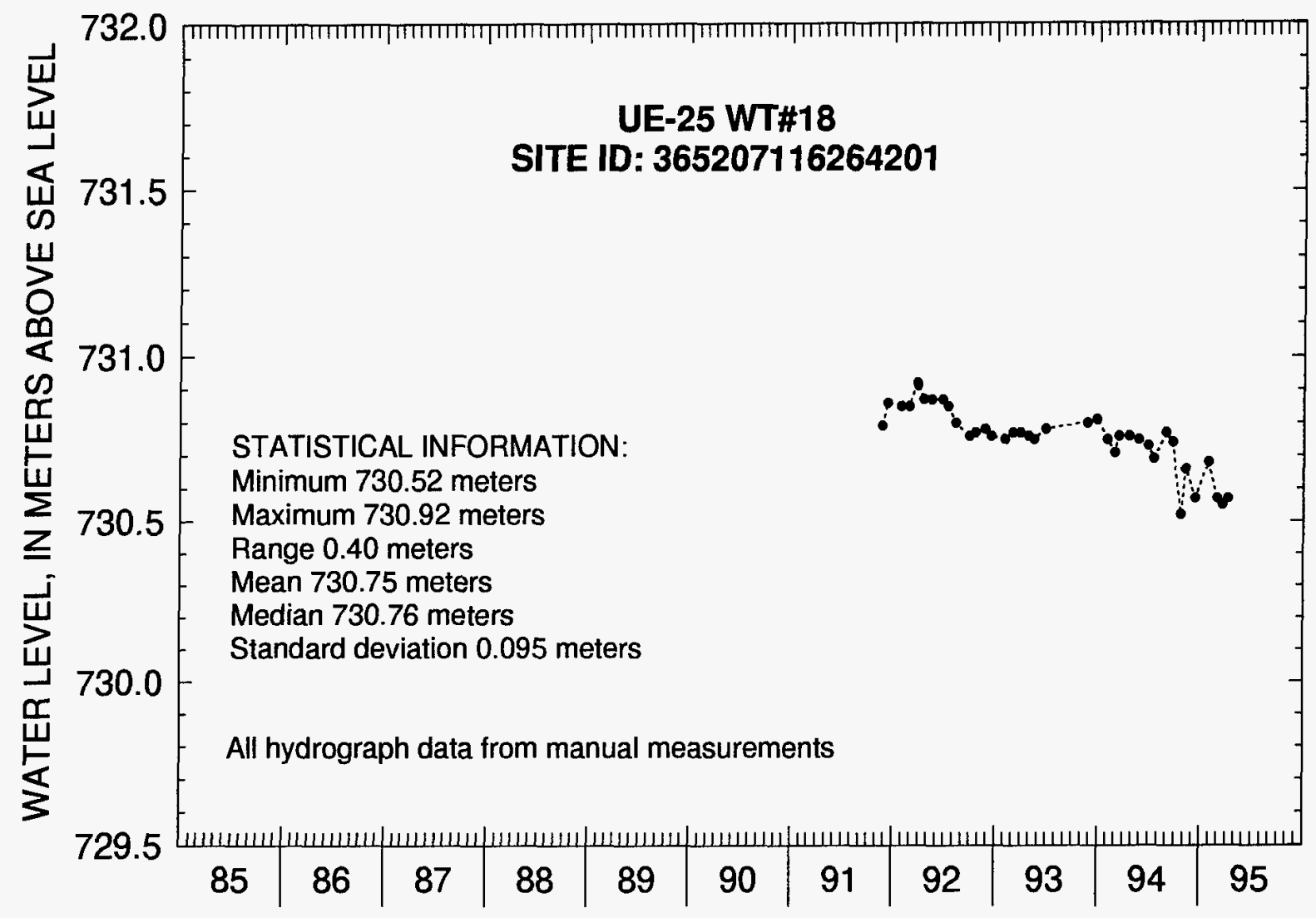

Figure 17. Water-level altitudes, 1985-95, for well UE-25 WT\#18.

\section{Well UE-25 b\#1, Upper Interval}

Water-level altitudes for well UE-25 b\#1, upper interval ranged from 730.48 to $730.79 \mathrm{~m}$ above sea level from 1985-95 (fig. 18). The mean annual water-level altitude for 1985-95 was $730.65 \mathrm{~m}$ above sea level. The median value was $730.63 \mathrm{~m}$. Standard deviation was $0.065 \mathrm{~m}$. The annual mean water-level altitudes for 1985-95 are as follows: 


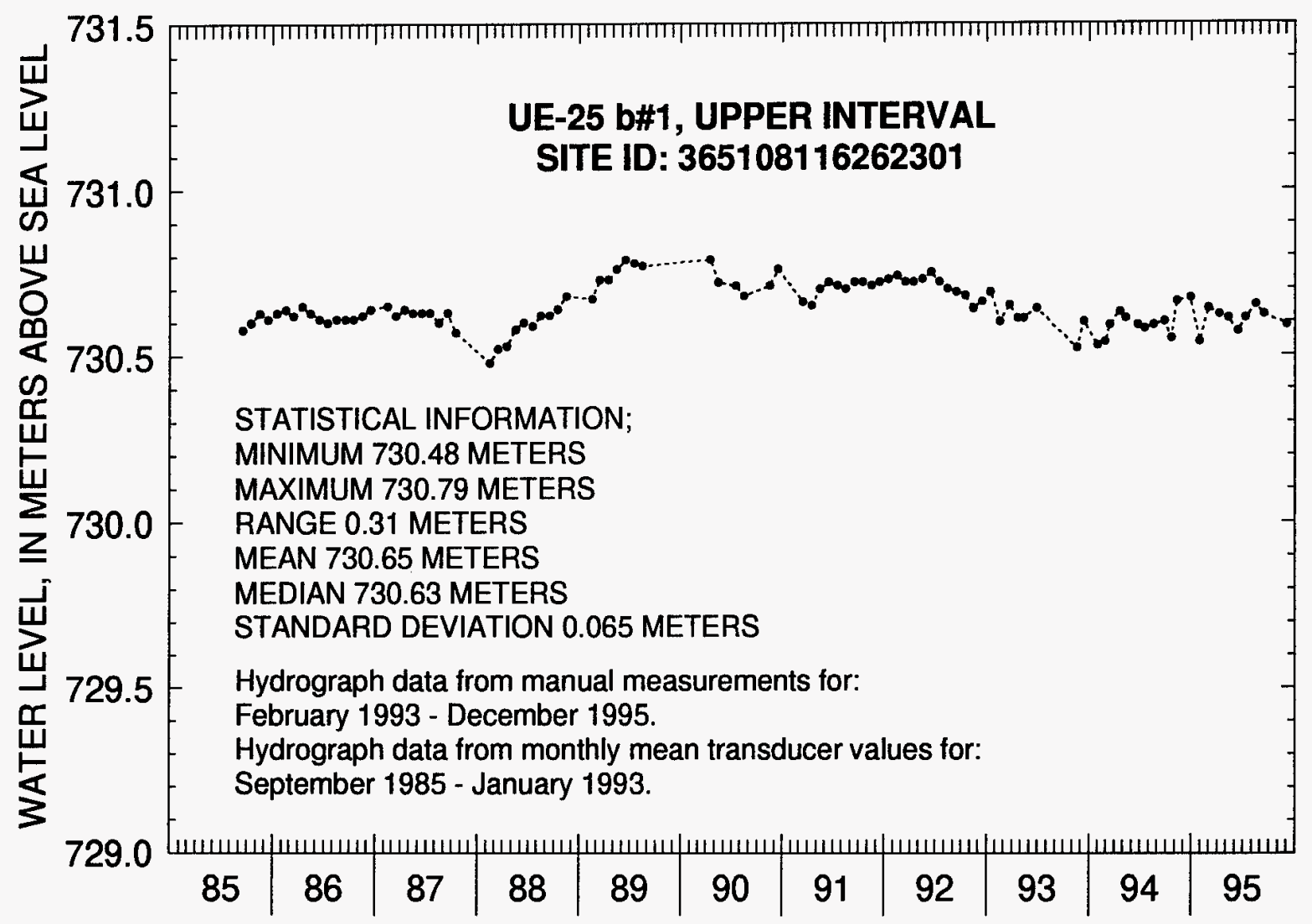

Figure 18. Water-level altitudes, 1985-95, for well UE-25 b\#1, upper interval.

\begin{tabular}{lc}
\hline Year & $\begin{array}{c}\text { Annual moan } \\
\text { water-level altitude } \\
\text { (meters) }\end{array}$ \\
\hline 1985 & 730.61 \\
1986 & 730.62 \\
1987 & 730.62 \\
1988 & 730.60 \\
1989 & 730.75 \\
1990 & 730.75 \\
1991 & 730.70 \\
1992 & 730.71 \\
1993 & 730.62 \\
1994 & 730.60 \\
1995 & 730.61 \\
\hline
\end{tabular}

Neither distinct seasonal trends in water-level changes or effects due to regional ground-water withdrawals were observed in well UE-25 b\#1, upper interval. Most changes in the water level can be attributed to barometric and Earth-tide changes. Over the 11 years of record, there is a rise in the water level from January 1985 through June 1992, followed by a decline in water level from July 1992 through December 1995. Whether it is coincidental or not, the decline in water level follows the regional earthquakes of June 28-29, 1992 (O'Brien, 1993). To determine if this shift in water level is due to the occurrence of the earthquakes or just due to cyclic patterns in the well, continuous long-term water-level data need to be collected. 


\section{Well UE-25 b\#1, Lower Interval}

Water-level altitude data is not available for well UE-25 b\#1 for 1986-87. Water-level altitudes for well UE-25 b\#1, lower interval ranged from 728.52 to $730.25 \mathrm{~m}$ above sea level from $1985-95$ (fig. 19). The mean annual water-level altitude for $1985-95$ was $729.67 \mathrm{~m}$ above sea level. The median value was $729.77 \mathrm{~m}$. Standard deviation was $0.425 \mathrm{~m}$. The annual mean water-level altitudes for $1985-95$ are as follows:

\begin{tabular}{cc}
\hline Year & $\begin{array}{c}\text { Annual mean } \\
\text { water-level altitude } \\
\text { (meters) }\end{array}$ \\
\hline 1985 & 728.54 \\
1986 & Data not available \\
1987 & Data not available \\
1988 & 729.64 \\
1989 & 729.71 \\
1990 & 729.81 \\
1991 & 729.63 \\
1992 & 729.84 \\
1993 & 729.92 \\
1994 & 730.06 \\
1995 & 729.98 \\
\hline
\end{tabular}

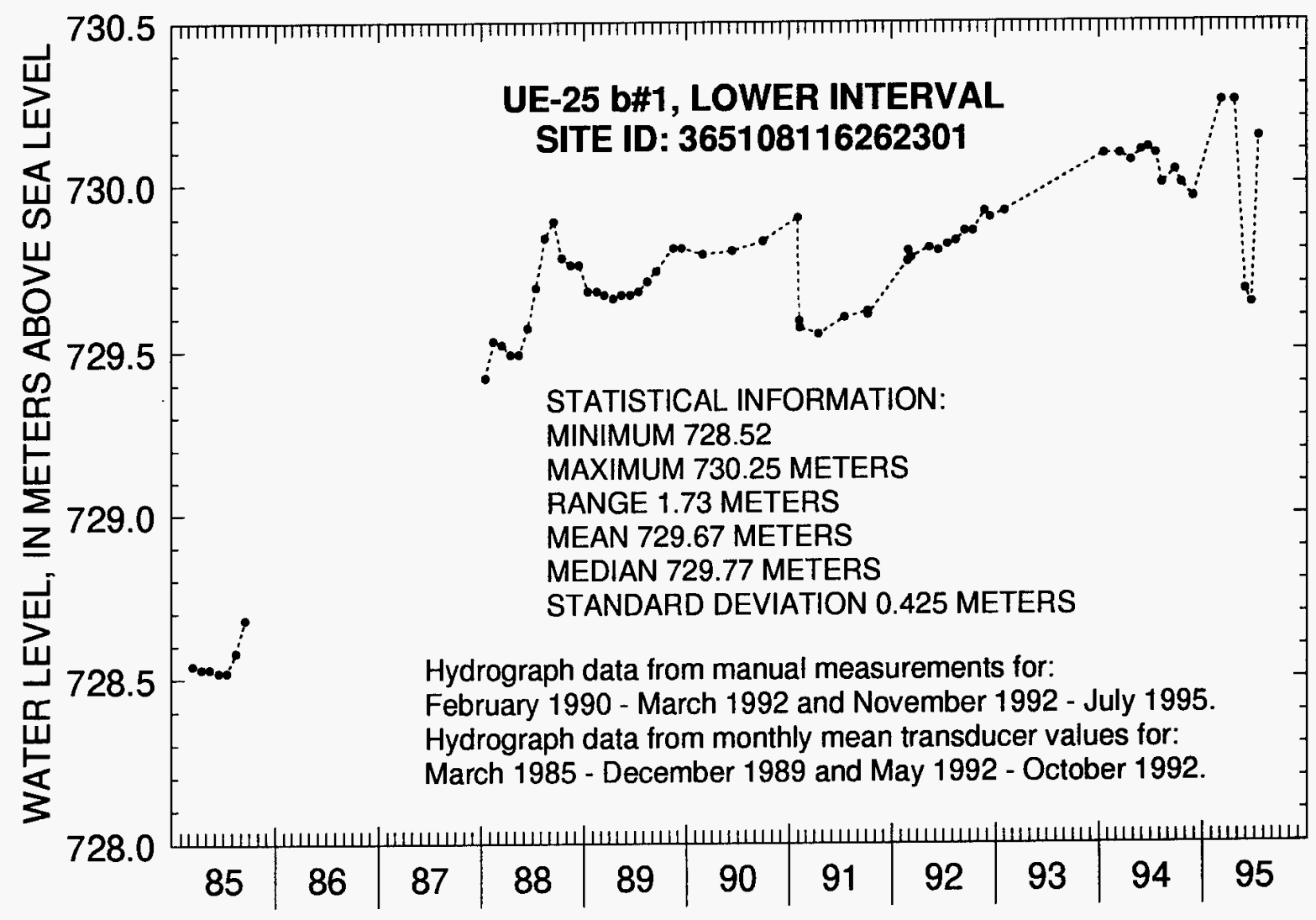

Figure 19. Water-level altitudes, 1985-95, for well UE-25 b\#1, lower interval. 
Neither distinct seasonal trends in water-level changes or effects due to regional ground-water withdrawals were observed in well UE-25 b\#1, lower interval. However, there is a distinct long-term rise in water level from July 1985 through January 1991, and from April 1991 through April 1995. Between January and February 1991, there is an abrupt decline in the water level of $0.31 \mathrm{~m}$, followed by minimal change through April 1991, when the water level began to rise. There was another abrupt decline in water level between April and May 1995 of $0.76 \mathrm{~m}$. This abrupt decline may be followed by a continued rise in water level, as is seen in the July 1995 water level; however due to funding cuts, measurements have not been made in this well since this date.

Luckey and others (1993) attribute the long-term rise of the water table through 1988 to the lower interval not reaching equilibrium following the placement of the packer in the well in 1983. The continuation of well recovery from May 1991 through April 1995 can also be attributed to the water level seeking equilibrium. There is no explanation for the sudden decline in water level in 1991 and 1995 . A review of the manual water-level measurement data indicated the data were good. To determine if the pattern of sharp decline in water levels in this well is cyclic, continuous long-term water-level data need to be collected.

\section{Well UE-25 p\#1}

Water-level altitudes for well UE-25 p\#1 ranged from 751.92 to $752.69 \mathrm{~m}$ above sea level from 1985-95 (fig. 20). The mean annual water-level altitude for $1985-95$ was $752.44 \mathrm{~m}$ above sea level. The median value was $752.49 \mathrm{~m}$. Standard deviation was $0.161 \mathrm{~m}$. The annual mean water-level altitudes for 1985-95 are as follows:

\begin{tabular}{cc}
\hline Year & $\begin{array}{c}\text { Annual mean } \\
\text { water-level altitude } \\
\text { (meters) }\end{array}$ \\
\hline 1985 & 752.11 \\
1986 & 752.27 \\
1987 & 752.44 \\
1988 & 752.54 \\
1989 & 752.54 \\
1990 & 752.55 \\
1991 & 752.45 \\
1992 & 752.33 \\
1993 & 752.49 \\
1994 & 752.55 \\
1995 & 752.57 \\
\hline
\end{tabular}

Between March 1985 and December 1990, there appears to be a cycle of rising and declining water levels every 21 to 22 months in well UE-25 p\#1. However, what confuses the interpretation of these water-level changes is the lack of continuous transducer data. The apparent cycles could be nothing more than barometric and Earth-tide-induced water-level changes that are accentuated to appear as sharp highs and lows because of the lack of data. Regardless of this apparent cycle, over the 11 years of record, there is an overall rise in water level from 1985-95. Also, there was a distinct water-level decline in well UE-25 p\#1 because of the earthquakes, which occurred in the region between June 28-29, 1992 (O'Brien, 1993). Following the earthquakes, the water level slowly recovered to re-establish the potentiometric equilibrium in the well (O'Brien and others, 1995). 


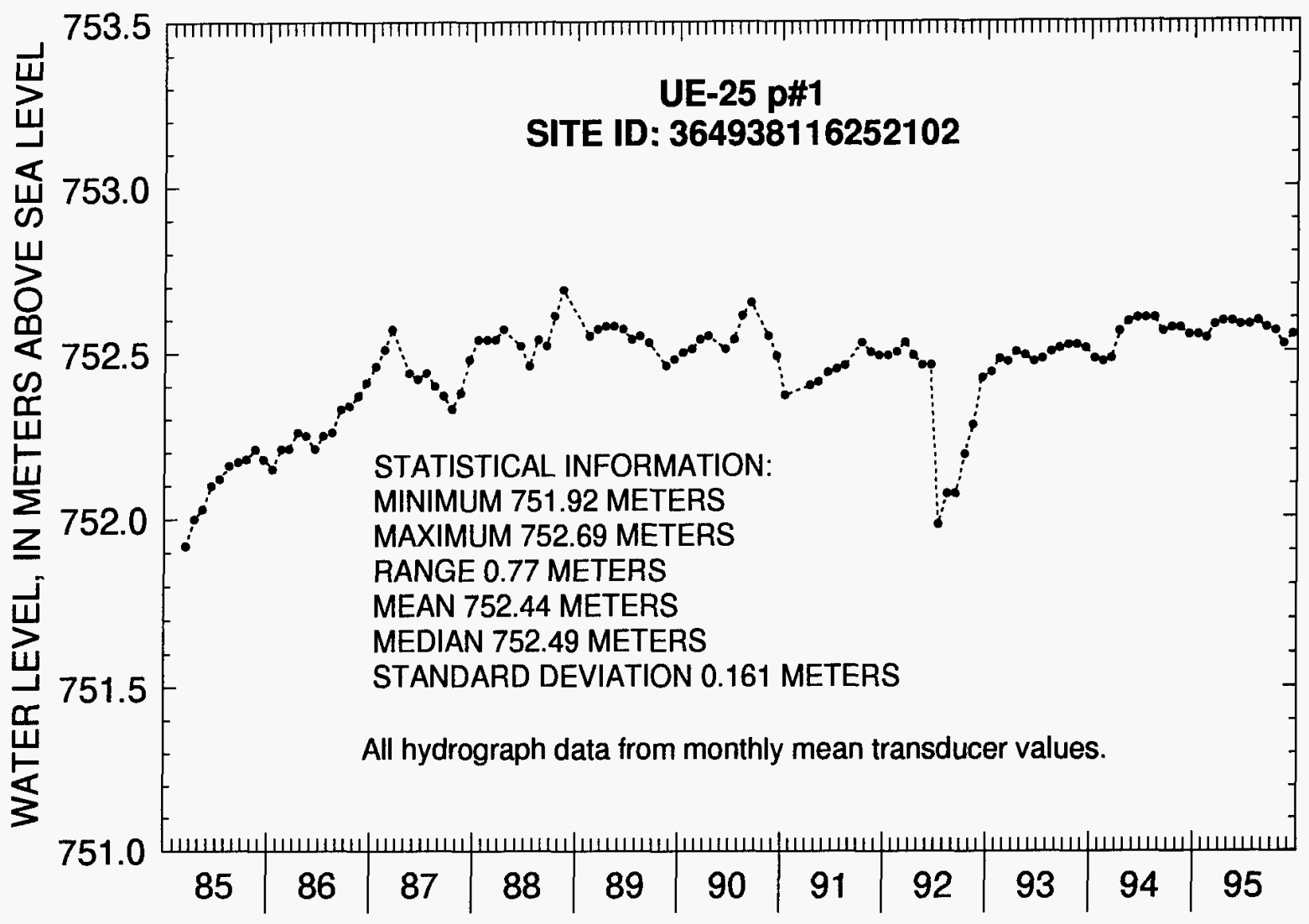

Figure 20. Water-level altitudes, 1985-95, for well UE-25 p\#1.

\section{Well USW VH-1}

Water-level altitudes for well USW VH-1 ranged from 779.30 to $779.60 \mathrm{~m}$ above sea level from 1985-95 (fig. 21). The mean annual water-level altitude for $1985-95$ was $779.44 \mathrm{~m}$ above sea level. The median value was $779.45 \mathrm{~m}$. Standard deviation was $0.048 \mathrm{~m}$. The annual mean water-level altitudes for 1985-95 are as follows:

\begin{tabular}{cc}
\hline Year & $\begin{array}{c}\text { Annual mean } \\
\text { water-level altitude } \\
\text { (meters) }\end{array}$ \\
\hline 1985 & 779.41 \\
1986 & 779.43 \\
1987 & 779.42 \\
1988 & 779.41 \\
1989 & 779.47 \\
1990 & 779.47 \\
1991 & 779.47 \\
1992 & 779.43 \\
1993 & 779.46 \\
1994 & 779.46 \\
1995 & 779.49 \\
\hline
\end{tabular}




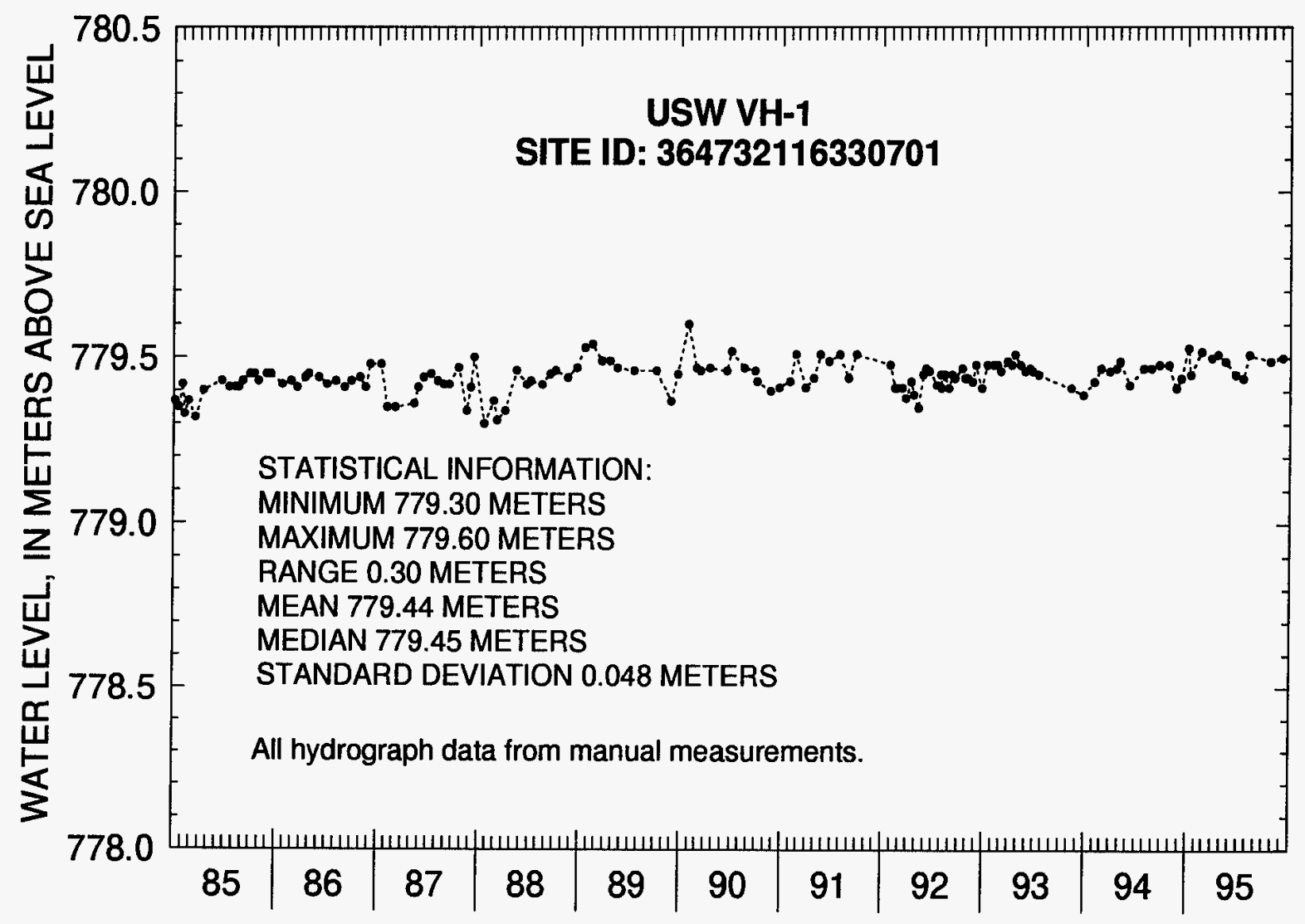

Figure 21. Water-level altitudes, 1985-95, for well USW VH-1.

Although drilled for the collection of hydrologic and geologic data from the underlying volcanic rocks, a pump was placed in well USW VH-1 during 1982, so the well could be used for water supply. From 1985-95, the well was pumped only during 1991, 1992, and 1994 (table 3) (Dick LaCamera, U.S. Geological Survey, written commun., 1996). During this period, a total of $6,040 \mathrm{~m}^{3}$ of ground water was pumped from the well.

Neither distinct seasonal trends in water-level changes or effects due to regional ground-water withdrawals were observed in well USW VH-1. Most changes in the water level can be attributed to barometric and Earth-tide changes. Over the 11 years of record, the water table in well USW VH-1 was stable, with no distinct rising or declining trends from 1985-95.

Table 3. Yearly discharge from well USW VH-1

\begin{tabular}{cc}
\hline Year & $\begin{array}{c}\text { Discharge } \\
\text { (cubic meters) }\end{array}$ \\
\hline 1985 & 0 \\
1986 & 0 \\
1987 & 0 \\
1988 & 0 \\
1989 & 0 \\
1990 & 0 \\
1991 & 2,734 \\
1992 & 2,531 \\
1993 & 0 \\
1994 & 775 \\
1995 & 0 \\
\hline
\end{tabular}




\section{Well USW G-2}

Water-level altitude data is not available for well USW G-2 from 1985 through 1991. Water-level altitudes for well USW G-2 ranged from $1,019.58$ to $1,020.56 \mathrm{~m}$ above sea level from $1992-95$ (fig. 22). The mean annual water-level altitude for $1992-95$ was $1,020.17 \mathrm{~m}$ above sea level. The median value was $1,020.12 \mathrm{~m}$. Standard deviation was $0.241 \mathrm{~m}$. The annual mean water-level altitudes for $1992-95$ are as follows:

\begin{tabular}{cc}
\hline Year & $\begin{array}{c}\text { Annual mean } \\
\text { water-level altitude } \\
\text { (meters) }\end{array}$ \\
\hline 1985 & Data not available \\
1986 & Data not available \\
1987 & Data not available \\
1988 & Data not available \\
1989 & Data not available \\
1990 & Data not available \\
1991 & Data not available \\
1992 & $1,020.52$ \\
1993 & $1,020.29$ \\
1994 & $1,020.10$ \\
1995 & $1,019.74$ \\
\hline
\end{tabular}

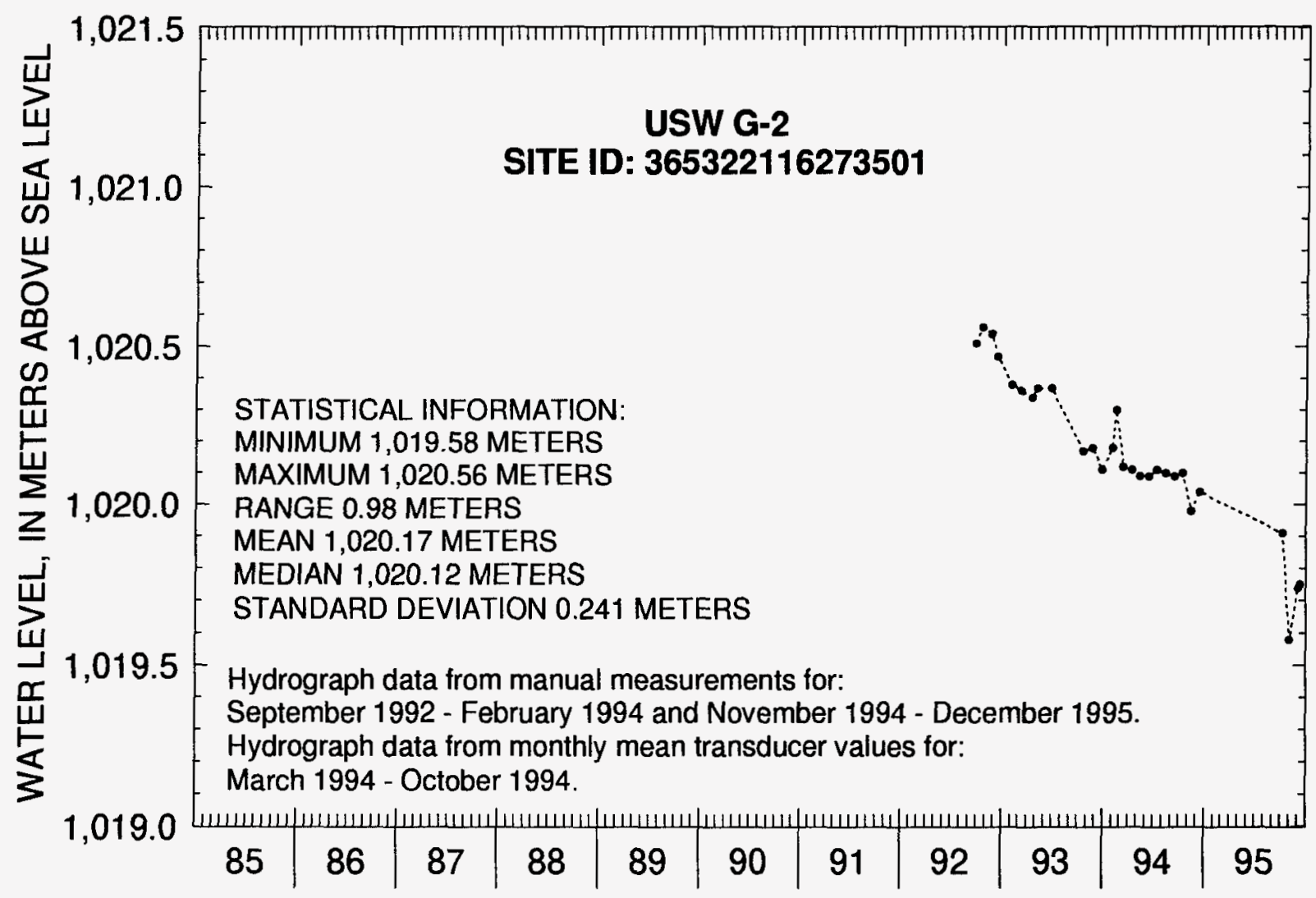

Figure 22. Water-level altitudes, 1985-95, for well USW G-2. 
Water-level data are not available for well USW G-2 from 1985 through 1991; however, data are available prior to 1985 . Since the well was completed on October 24, 1981, the water level in the well has been declining. Water-level measurements made on November 10, 1981, and September 17, 1982, indicate an altitude of $1,031.82$ and $1,028.84 \mathrm{~m}$, respectively. During 1995, well USW G-2 was instrumented to conduct a single-well aquifer test. Pump failure prevented the test from being conducted, and from October 24 through November 1, 1995, only pretesting pump cycles of 10 to 15 minutes pumping at approximately $0.95 \mathrm{~L} / \mathrm{s}$ were completed. It is estimated that approximately $10 \mathrm{~m}^{3}$ of ground water was pumped from well USW G-2 and maximum drawdown was about $3.5 \mathrm{~m}$ (Grady O'Brien, U.S. Geological Survey, oral commun., 1996). This pumpage and slow water-level recovery would explain the sharp decline and partial recovery of the water level during 1995.

\section{Well USW G-3}

Water-level altitudes for well USW G-3 ranged from 729.96 to $730.83 \mathrm{~m}$ above sea level from 1985-95 (fig. 23). The mean annual water-level altitude for $1985-95$ was $730.50 \mathrm{~m}$ above sea level. The median value was $730.51 \mathrm{~m}$. Standard deviation was $0.169 \mathrm{~m}$. The annual mean water-level altitudes for $1985-95$ are as follows:

\begin{tabular}{cc}
\hline Year & $\begin{array}{c}\text { Annual mean } \\
\text { water-level altitude } \\
\text { (meters) }\end{array}$ \\
\hline 1985 & 730.27 \\
1986 & 730.64 \\
1987 & 730.67 \\
1988 & 730.57 \\
1989 & 730.37 \\
1990 & 730.48 \\
1991 & 730.45 \\
1992 & 730.49 \\
1993 & 730.57 \\
1994 & 730.45 \\
1995 & 730.64 \\
\hline
\end{tabular}

Neither distinct seasonal trends in water-level changes or effects due to regional ground-water withdrawals were observed in well USW G-3. Most changes in the water level can be attributed to barometric and Earth-tide changes. Robison and others (1988) reported that the November 20, 1985, measurement (Appendix B) was about $0.50 \mathrm{~m}$ below the general trend of the water level for that year. A review of the field notes indicated that the measurement was good; however, Robison could give no explanation for the quick change in water level. The 11 years of available record indicate that this abrupt change in water level was not a one-time event. Since 1985, the water level in the well has declined rapidly two times, once during 1988 and again during 1994. Though some changes are more gradual than others, the waterlevel change is still approximately $0.50 \mathrm{~m}$. There is still no explanation for this relatively sudden change in water level.

Overall, there is not a distinct long-term rise or decline in the water table. Although the abrupt change in water level tends to give a wide range of mean-annual water levels from year to year, the mean annual water level for 1986 is the same as for 1995. To determine how cyclic any of the changes occurring in this well are, continuous long-term data need to be collected. 


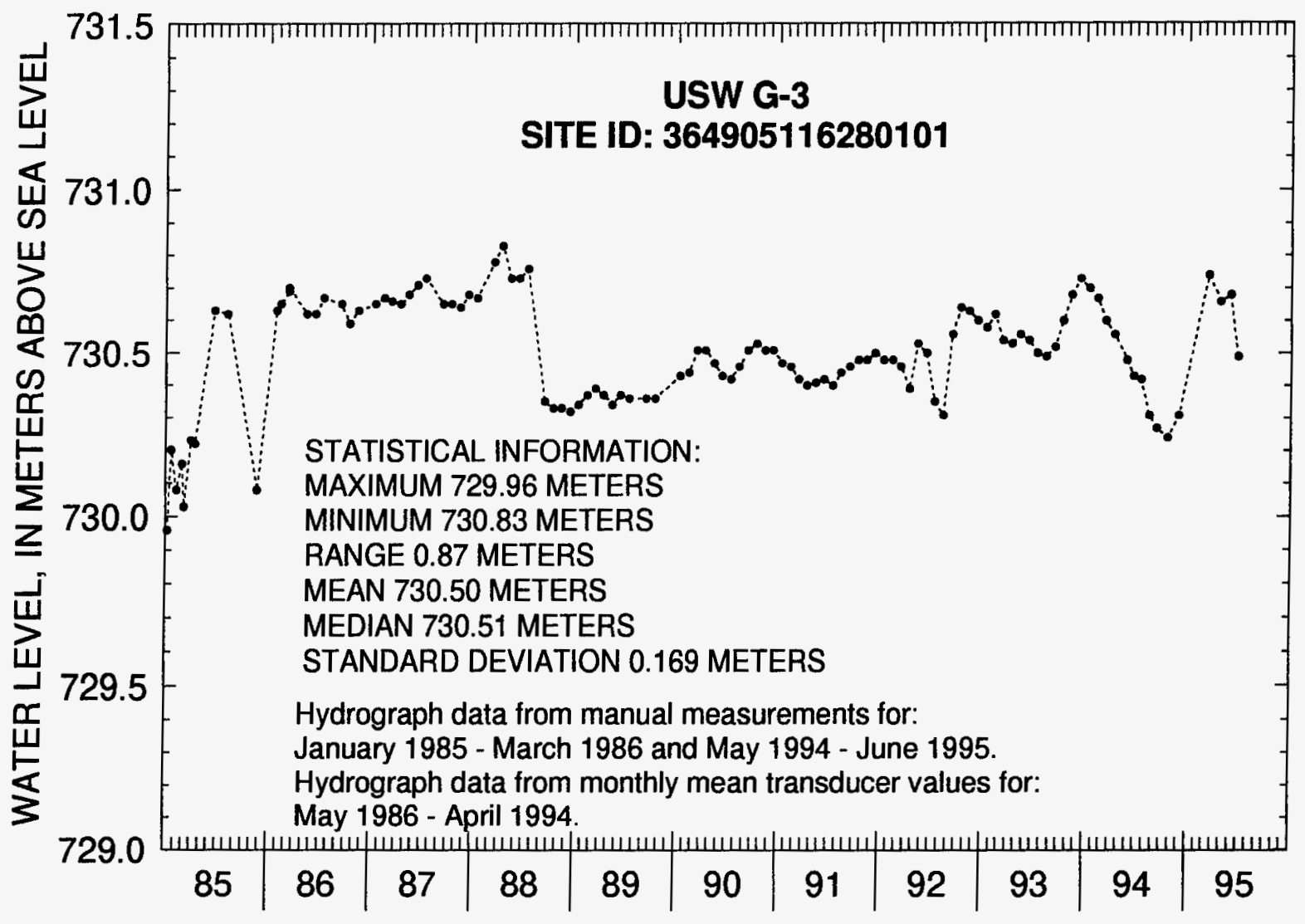

Figure 23. Water-level altitudes, $1985-95$, for well USW G-3.

\section{Well J-11}

Water-level altitude data are not available for well J-11 from 1985 through 1988 . Water-level altitudes for well J-11 ranged from 732.09 to $732.40 \mathrm{~m}$ above sea level from $1989-95$ (fig. 24). The mean annual water-level altitude for $1989-95$ was $732.21 \mathrm{~m}$ above sea level. The median value was $732.20 \mathrm{~m}$. Standard deviation was $0.055 \mathrm{~m}$. The annual mean water-level altitudes for 1989-95 are as follows:

\begin{tabular}{cc}
\hline Year & $\begin{array}{c}\text { Annual mean } \\
\text { water-level altitude } \\
\text { (meters) }\end{array}$ \\
\hline 1985 & Data not available \\
1986 & Data not available \\
1987 & Data not available \\
1988 & Data not available \\
1989 & 732.17 \\
1990 & 732.24 \\
1991 & 732.20 \\
1992 & 732.20 \\
1993 & 732.21 \\
1994 & 732.21 \\
1995 & 732.25 \\
\hline
\end{tabular}


Neither distinct seasonal trends in water-level changes or effects due to regional ground-water withdrawals were observed in well J-11. Most changes in the water level can be attributed to barometric and Earth-tide changes. Over the 7 years of available record, the water level in well $\mathrm{J}-11$ was stable with no distinct rising or declining trends from 1989-95. Of note, although well J-11 was drilled as a watersupply well, it was never used due to low discharge rates.

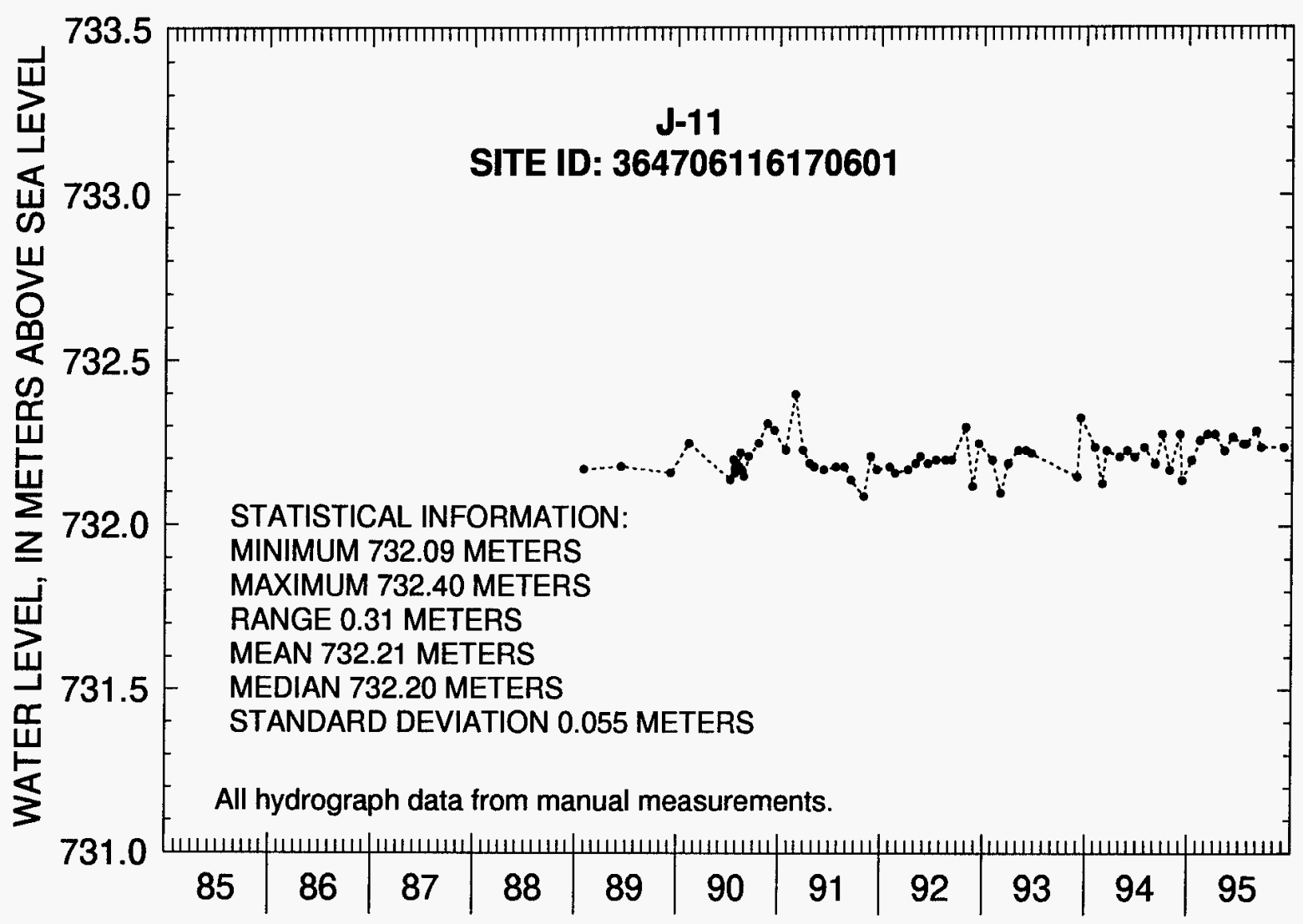

Figure 24. Water-level altitudes, 1985-95, for well J-11.

\section{Well J-12}

Water-level altitude data are not available for well J-12 from 1985 through 1988 . Water-level altitudes for well J-12 ranged from 727.81 to $728.15 \mathrm{~m}$ above sea level from 1989-95 (fig. 25). The mean annual water-level altitude for $1989-95$ was $727.93 \mathrm{~m}$ above sea level. The median value was $727.94 \mathrm{~m}$. Standard deviation was $0.053 \mathrm{~m}$. The annual mean water-level altitudes for 1989-95 are as follows: 


\begin{tabular}{cc}
\hline Year & $\begin{array}{c}\text { Annual mean } \\
\text { water-level altitude } \\
\text { (meters) }\end{array}$ \\
\hline 1985 & Data not available \\
1986 & Data not available \\
1987 & Data not available \\
1988 & Data not available \\
1989 & 727.95 \\
1990 & 727.94 \\
1991 & 727.95 \\
1992 & 727.96 \\
1993 & 727.85 \\
1994 & 727.91 \\
1995 & 727.90 \\
\hline
\end{tabular}

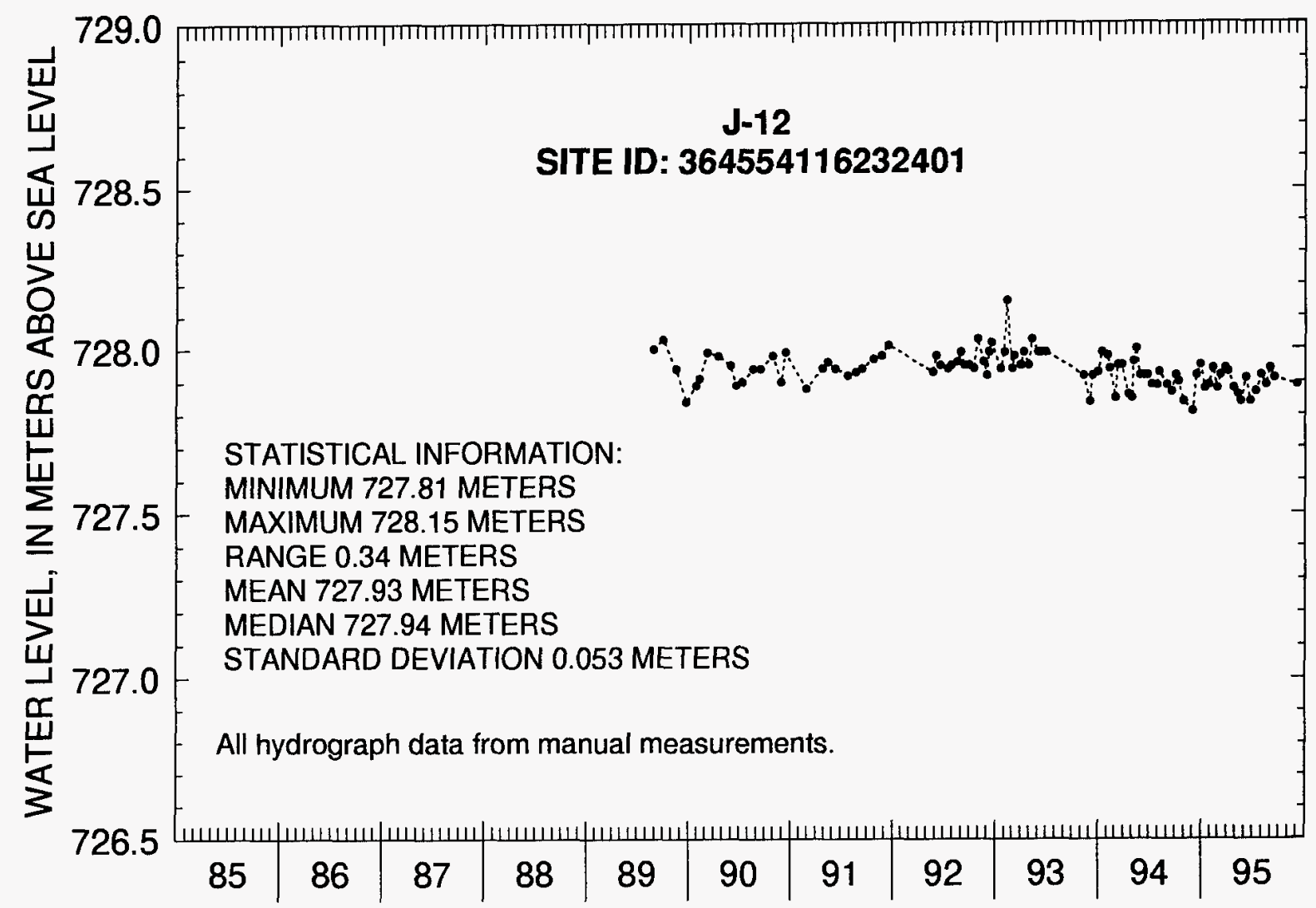

Figure 25. Water-level altitudes, 1985-95, for well J-12.

Well J-12 is one of three pumping wells monitored in the Yucca Mountain area. Although water-level data were not available before 1989, ground-water-withdrawal data are available (table 4) (Dick LaCamera, U.S. Geological Survey, written commun., 1996). From 1985-95, a total of about $1,196,500 \mathrm{~m}^{3}$ was pumped from the well. Seasonal trends in water-level changes were not observed in well J-12. Month-to-month changes in the water level could be due to monthly withdrawals from the well or to barometric and Earth-tide changes. Over the 7 years of available water-level record from 
1989-95, there is a general decline in the water level in well J-12. It is not known if this decline in water level is due to gradual dewatering of the aquifer due to ground-water withdrawals, or if it is a localized trend as seen in other wells.

Table 4. Yearly discharge from well $\mathrm{J}-12$

\begin{tabular}{cc}
\hline Year & $\begin{array}{c}\text { Discharge } \\
\text { (cubic meters) }\end{array}$ \\
\hline 1985 & 99,000 \\
1986 & 108,200 \\
1987 & 76,900 \\
1988 & 77,500 \\
1989 & 127,100 \\
1990 & 118,100 \\
1991 & 131,300 \\
1992 & 47,400 \\
1993 & 94,500 \\
1994 & 181,500 \\
1995 & 135,000 \\
\hline
\end{tabular}

\section{Well J-13}

Water-level altitude data are not available for well J-13 for 1985 . Water-level altitudes for well J13 ranged from 728.30 to $728.69 \mathrm{~m}$ above sea level from $1986-95$ (fig. 26). The mean annual water-level altitude for $1986-95$ was $728.44 \mathrm{~m}$ above sea level. The median value was also $728.44 \mathrm{~m}$. Standard deviation was $0.065 \mathrm{~m}$. The annual mean water-level altitudes for 1986-95 are as follows:

\begin{tabular}{cc}
\hline Year & $\begin{array}{c}\text { Annual mean } \\
\text { water-level altitude } \\
\text { (meters) }\end{array}$ \\
\hline 1985 & Data not available \\
1986 & 728.45 \\
1987 & 728.38 \\
1988 & 728.45 \\
1989 & 728.45 \\
1990 & 728.44 \\
1991 & 728.48 \\
1992 & 728.46 \\
1993 & 728.46 \\
1994 & 728.40 \\
1995 & 728.43 \\
\hline
\end{tabular}

Well J-13 is one of three pumping wells monitored in the Yucca Mountain area. Although water-level data were not available for 1985, ground-water-withdrawal data were available (table 5 , Dick LaCamera, U.S. Geological Survey, written commun., 1996). From 1985-95, a total of about $1,197,000 \mathrm{~m}^{3}$ of ground water was pumped from the well. Seasonal trends in water-level changes were not observed in well J-13. Month-to-month fluctuations in the water level could be due to monthly withdrawals from the well or to barometric or Earth-tide changes. Over the 10 years of available water-level record from 1986-95, the water level in well J-13 was stable, with no distinct rising or declining trends from 1986-95. This would indicate that there is no measurable dewatering of the aquifer at this site due to ground-water pumpage. 


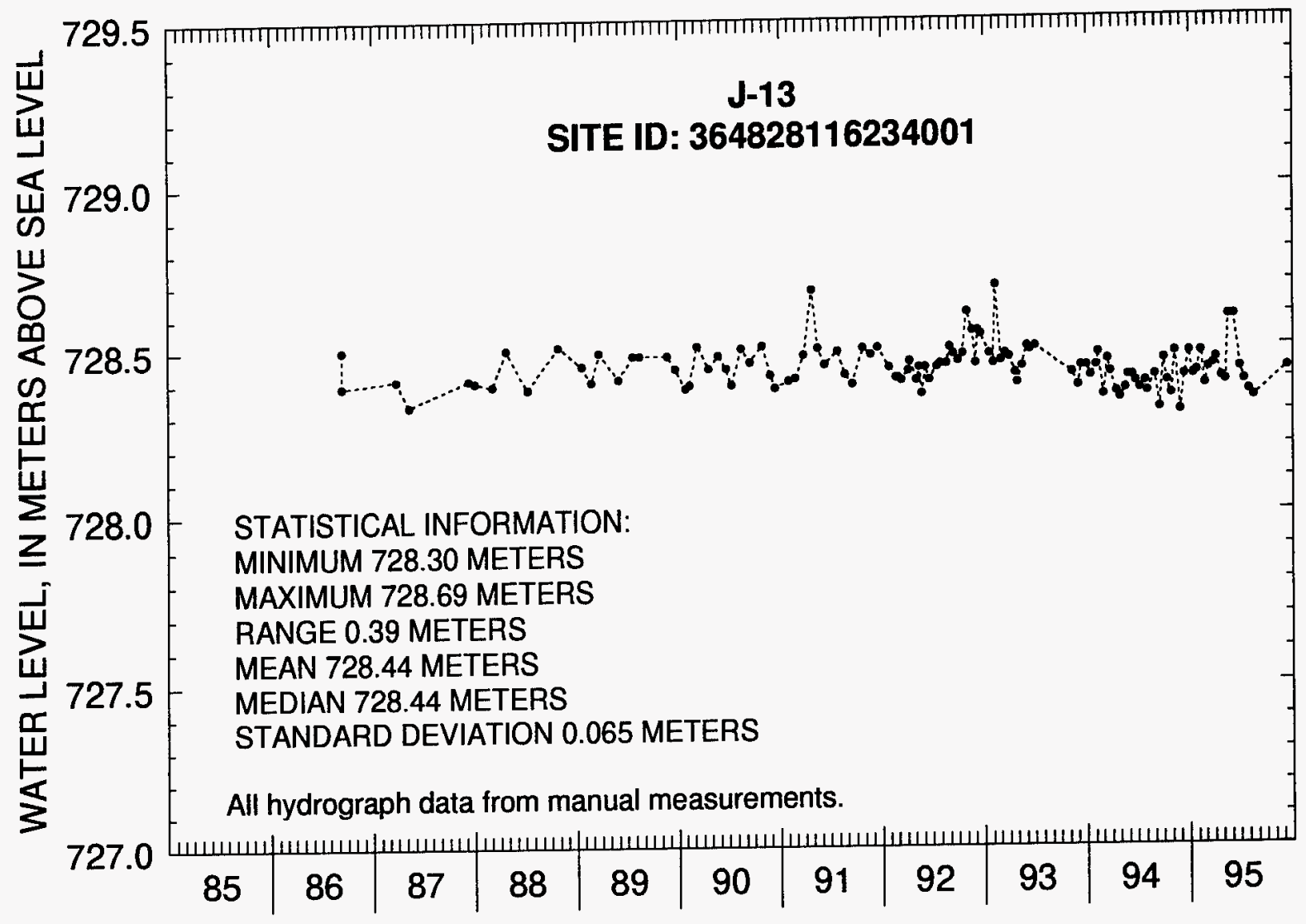

Figure 26. Water-level altitudes, 1985-95, for well J-13.

Table 5. Yearly discharge from well $\mathrm{J}-13$

\begin{tabular}{cc}
\hline Year & $\begin{array}{c}\text { Discharge } \\
\text { (cubic moters) }\end{array}$ \\
\hline 1985 & 103,800 \\
1986 & 66,000 \\
1987 & 123,300 \\
1988 & 96,700 \\
1989 & 64,200 \\
1990 & 77,500 \\
1991 & 62,600 \\
1992 & 99,900 \\
1993 & 158,400 \\
1994 & 160,000 \\
1995 & 184,600 \\
\hline
\end{tabular}




\section{Well USW H-1, Tube 1}

Water-level altitudes for well USW H-1, tube 1 ranged from 785.00 to $786.05 \mathrm{~m}$ above sea level from 1985-95 (fig. 27). The mean annual water-level altitude for 1985-95 was 785.49 m above sea level. The median value was also $785.49 \mathrm{~m}$. Standard deviation was $0.272 \mathrm{~m}$. The annual mean water-level altitudes for 1985-95 are as follows:

\begin{tabular}{cc}
\hline Year & $\begin{array}{c}\text { Annual mean } \\
\text { water-level altitude } \\
\text { (meters) }\end{array}$ \\
\hline 1985 & 785.18 \\
1986 & 785.24 \\
1987 & 785.22 \\
1988 & 785.08 \\
1989 & 785.21 \\
1990 & 785.36 \\
1991 & 785.59 \\
1992 & 785.63 \\
1993 & 785.58 \\
1994 & 785.74 \\
1995 & 785.98 \\
\hline
\end{tabular}

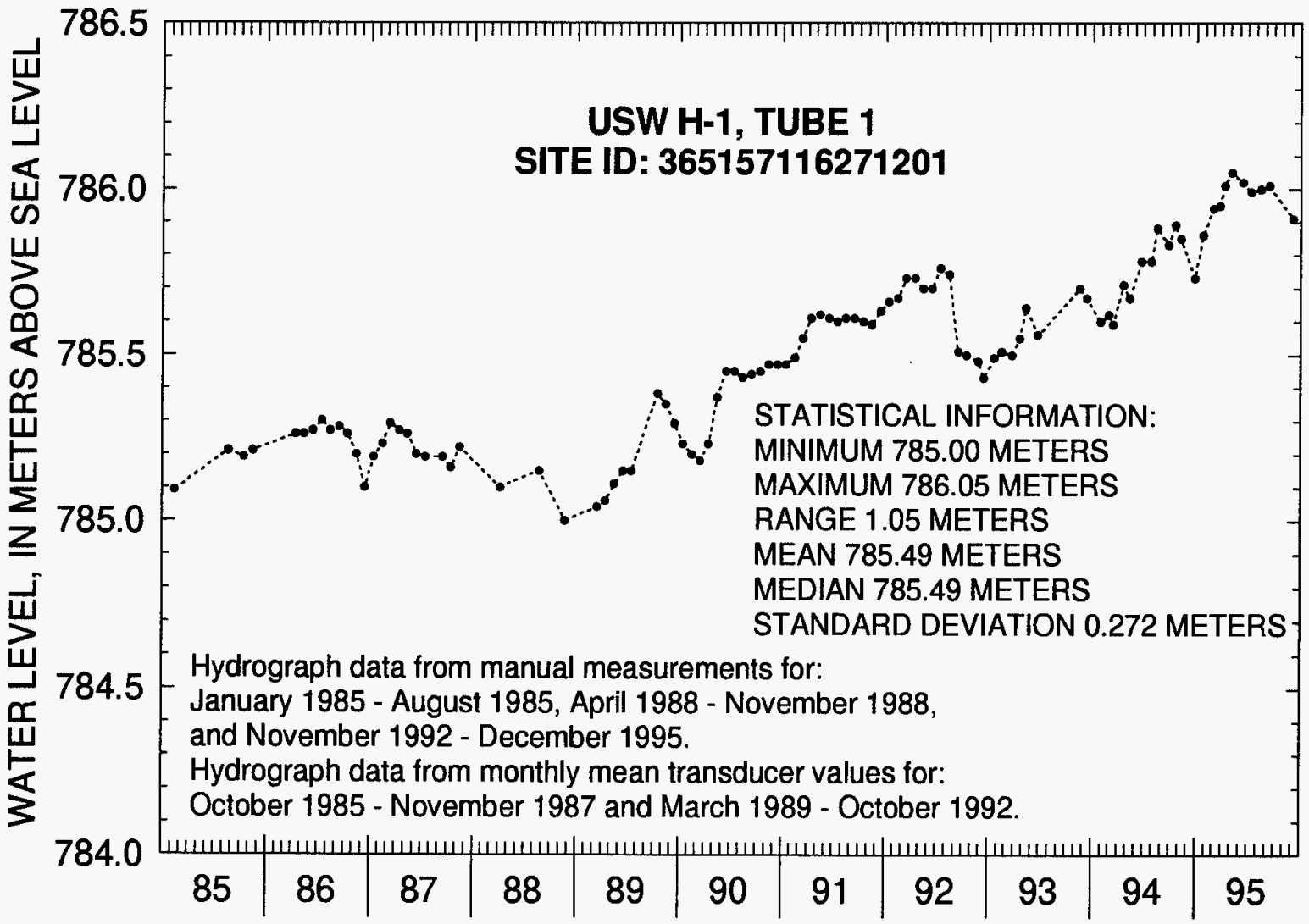

Figure 27. Water-level altitudes, 1985-95, for well USW H-1, tube 1. 
Neither distinct seasonal trends in water-level changes or effects due to regional ground-water withdrawals were observed in well USW H-1, tube 1 . Over the 11 years of record, there is an overall rise in water level from 1985-95. For short-term trends, there is a gradual rise in water level from January 1985 through July 1986, followed by an overall decline in water level from August 1986 through November 1988, and then an overall rise in water level from March 1989 through December 1995. During the period from November 1988 through December 1995, periods of relatively quick declines in water level are followed by a continuation of the rise in water level. One of these periods began 2 months following the regional earthquakes, which took place June 28-29, 1992 (O'Brien, 1993). However, because of the previous trends of rapid declines in water level, the September 1992 decline may have occurred regardless of the June earthquakes. Whereas, month-to-month water-level changes in other intervals of the well are due to barometric or Earth-tide changes, O'Brien and others (1995) report that historically, tube 1 is insensitive to water-level changes caused by barometric pressure and Earth-tide changes. The driving force that causes the monthly water-level fluctuations or long-term rises and cyclic declines is not known.

\section{Well USW H-1, Tube 2}

Water-level altitudes for well USW H-1, tube 2 ranged from 735.67 to $736.28 \mathrm{~m}$ above sea level from 1985-95 (fig. 28). The mean annual water-level altitude for 1985-95 was $735.97 \mathrm{~m}$ above sea level. The median value was $735.95 \mathrm{~m}$. Standard deviation was $0.161 \mathrm{~m}$. The annual mean water-level altitudes for 1985-95 are as follows:

\begin{tabular}{cc}
\hline Year & $\begin{array}{c}\text { Annual mean } \\
\text { water-level altitude } \\
\text { (meters) }\end{array}$ \\
\hline 1985 & 736.26 \\
1986 & Data not available \\
1987 & 736.28 \\
1988 & 736.11 \\
1989 & 735.96 \\
1990 & 736.15 \\
1991 & 736.08 \\
1992 & 735.98 \\
1993 & 735.94 \\
1994 & 735.87 \\
1995 & 735.74 \\
\hline
\end{tabular}

Neither distinct seasonal trends in water-level changes or effects due to regional ground-water withdrawals were observed in well USW H-1, tube 2. Data are not available for well USW H-1, tube 2 for 1986 because the transducer data was not converted to water levels. Over the 10 years of record, there is an overall decline in water level from 1985-95.

Well USW H-1, tube 2 has a history of being insensitive to water-level changes caused by barometric or Earth-tide changes (O'Brien and others, 1995). A review of the hydrograph through May 1993 supports this observation. However, beginning with June 1993 and continuing through February 1994, rapid rises and declines in water levels are observed. This period is followed by more gradual water-level changes but with a greater magnitude than observed before June 1993. Without attributing these changes to barometric or Earth-tide effects, it is not known why these changes occur.

Questionable water levels are found in the data for well USW H-1, tube 2. The drastic decline in water level between the August and November 1988 measurements is approximately $1 \mathrm{ft}$. As mentioned by Robison and others (1988), since manual water-level measurements are made in feet, an error of $1 \mathrm{ft}$ 
could have been made in reading the steel tape used to make the November 1988 measurement. However, although the data are questionable, no errors could be found in the field notes to validate not using the data, and the water-level measurement was used. Subsequently, the transducer placed in tube 2 during November 1988 could have been calibrated to erroneous data.

From November 1988 through July 1989, the transducer in well USW H-1, tube 2 was not removed from the well, and all calibration water levels were made with a transducer tag on the water surface. Because tagging the water level with the transducer gives only relative change in water level since the last manual measurement, the error introduced during November 1988 would continue until the next manual water-level measurement was made. This measurement was not made until October 1989, when a rise of approximately $1 \mathrm{ft}$ is observed in the data. This measurement is in agreement with the August 1988 water-level measurement. Subsequently, the water-level data from November 1988 through July 1989 , are probably in error (water level lower than it should be) by $1 \mathrm{ft}$.

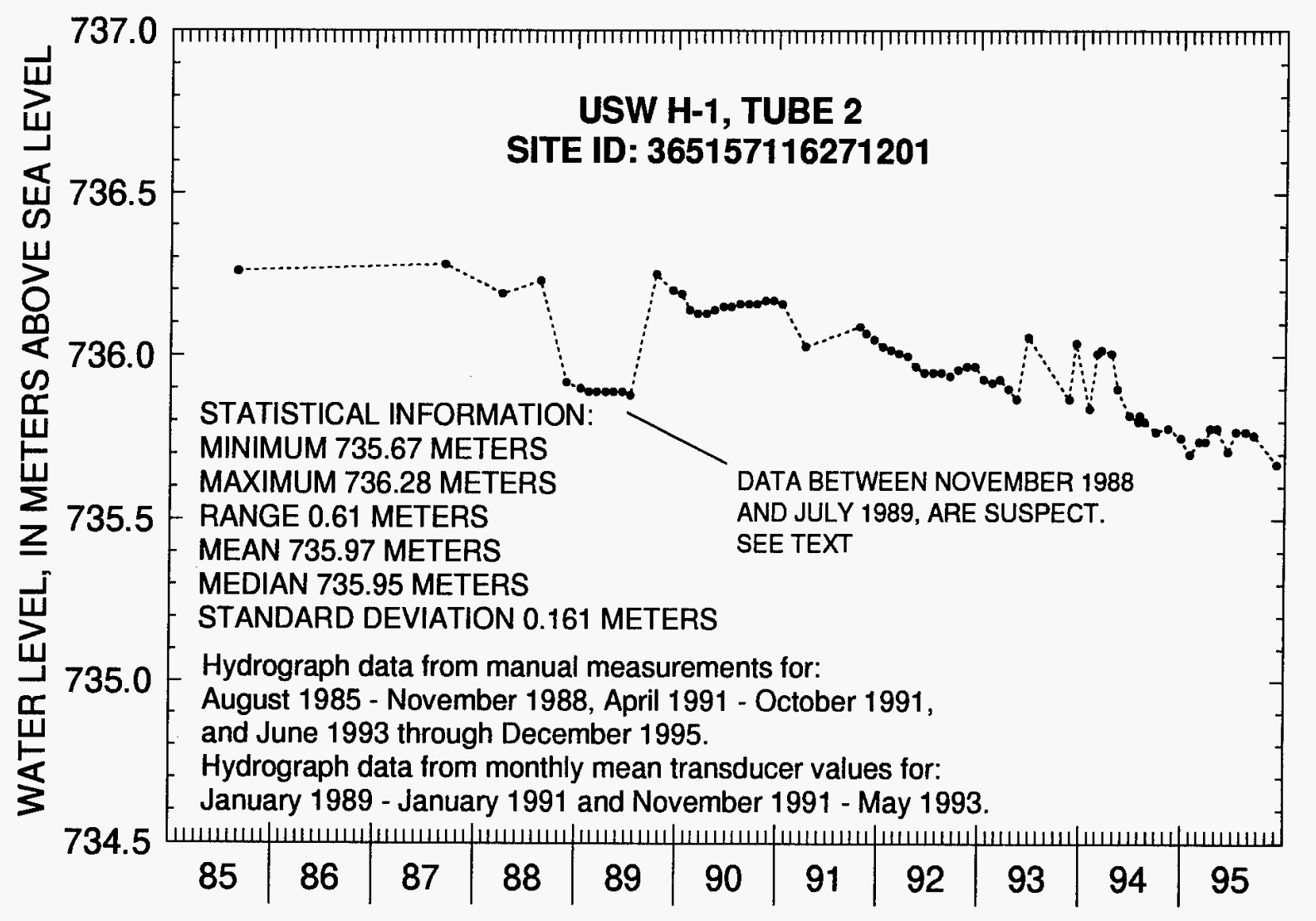

Flgure 28. Water-level altitudes, 1985-95, for well USW H-1, tube 2.

\section{Well USW H-1, Tube 3}

Water-level altitudes for well USW H-1, tube 3 ranged from 730.35 to $730.81 \mathrm{~m}$ above sea level from 1985-95 (fig. 29). The mean annual water-level altitude for $1985-95$ was $730.60 \mathrm{~m}$ above sea level. The median value was $730.62 \mathrm{~m}$. Standard deviation was $0.098 \mathrm{~m}$. The annual mean water-level altitudes for 1985-95 are as follows: 


\begin{tabular}{ll}
\hline Year & $\begin{array}{c}\text { Annual mean } \\
\text { water-level altitude } \\
\text { (meters) }\end{array}$ \\
\hline 1985 & 730.71 \\
1986 & 730.63 \\
1987 & 730.66 \\
1988 & 730.48 \\
1989 & 730.51 \\
1990 & 730.49 \\
1991 & 730.75 \\
1992 & 730.70 \\
1993 & 730.64 \\
1994 & 730.58 \\
1995 & 730.64 \\
\hline
\end{tabular}

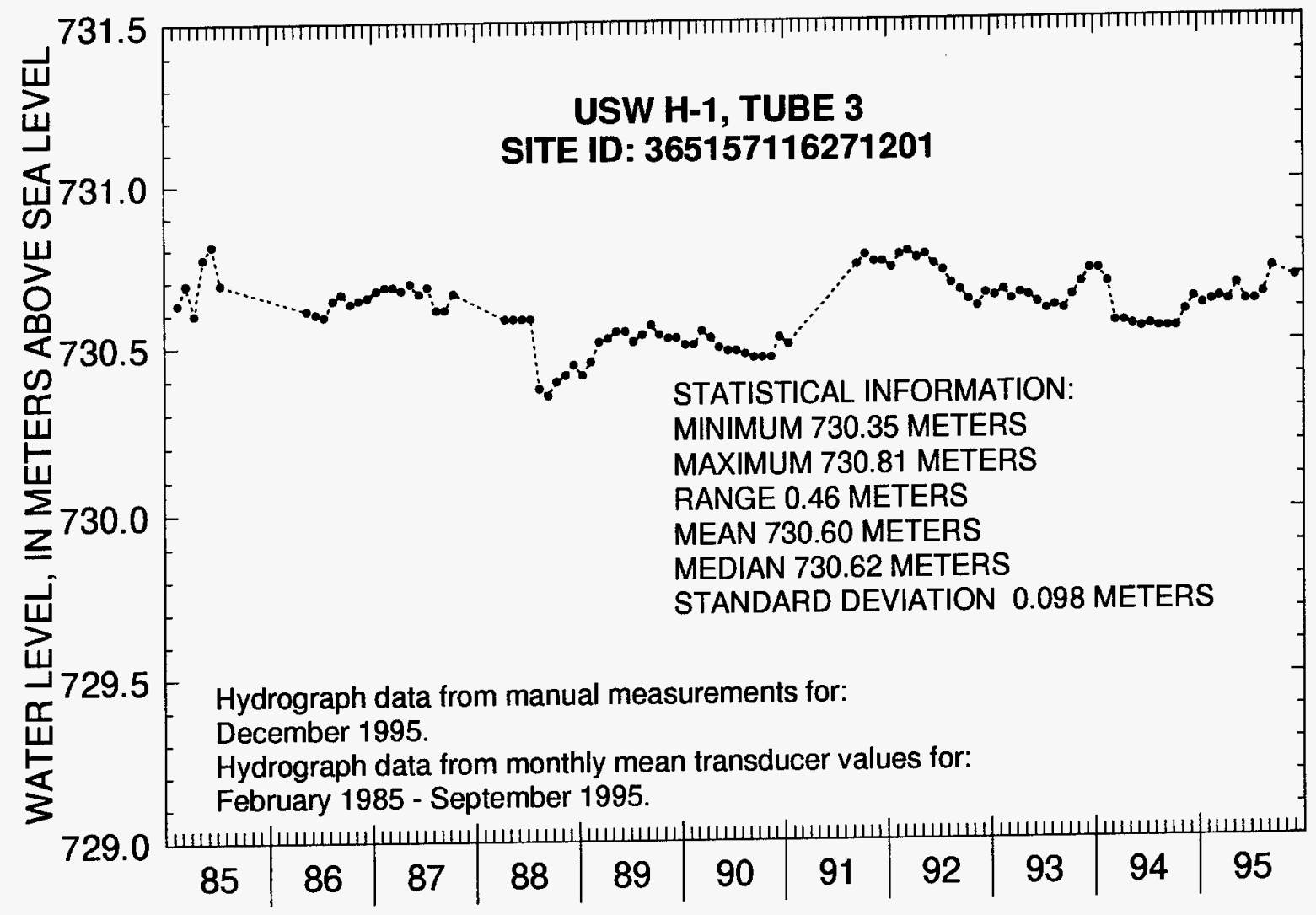

Figure 29. Water-level altitudes, 1985-95, for well USW H-1, tube 3. 
Neither distinct seasonal trends in water-level changes or effects due to regional ground-water withdrawals were observed in well USW H-1, tube 3 . Over the 11 years of record, there is a series of rises and declines in the water level. This series begins with a gradual decline in water level from January 1985 through November 1990, followed by a rise in water level from December 1990 through May 1992, and then another overall decline in water level from June 1992 through October 1994, and finally a rise in water level from November 1994 through December 1995. Water-level fluctuations within these periods of highs and lows appear to be controlled by barometric change and Earth-tide changes. However, there is no explanation for the long-term trends from 1985-95, or rapid rise during 1991. To determine if these changes are cyclic (long-term change) or repeatable (quick short-term changes), more continuous long-term water-level data need to be collected.

\section{Well USW H-1, Tube 4}

Water-level altitudes for well USW H-1, tube 4 ranged from 730.51 to $731.04 \mathrm{~m}$ above sea level from 1985-95 (fig. 30). The mean annual water-level altitude for $1985-95$ was $730.85 \mathrm{~m}$ above sea level. The median value was $730.90 \mathrm{~m}$. Standard deviation was $0.126 \mathrm{~m}$. The annual mean water-level altitudes for 1985-95 are as follows:

\begin{tabular}{cc}
\hline Year & $\begin{array}{c}\text { Annual mean } \\
\text { water-level altitude } \\
\text { (meters) }\end{array}$ \\
\hline 1985 & 730.69 \\
1986 & 730.67 \\
1987 & 730.67 \\
1988 & 730.94 \\
1989 & 730.93 \\
1990 & 730.92 \\
1991 & 730.94 \\
1992 & 730.93 \\
1993 & 730.90 \\
1994 & 730.87 \\
1995 & 730.90 \\
\hline
\end{tabular}

Neither distinct seasonal trends in water-level changes or effects due to regional ground-water withdrawals were observed in well USW H-1, tube 4. Following an abrupt rise and decline in water level from February through June 1985, there is an overall rise in water level from July 1985 through December 1988, which is punctuated by intermittent highs and lows that were controlled by barometric and Earth-tide changes. From January 1989 through December 1995, with the exception of changes also due to barometric or Earth-tide changes, the water level was stable, with no distinct increasing or decreasing trends. 


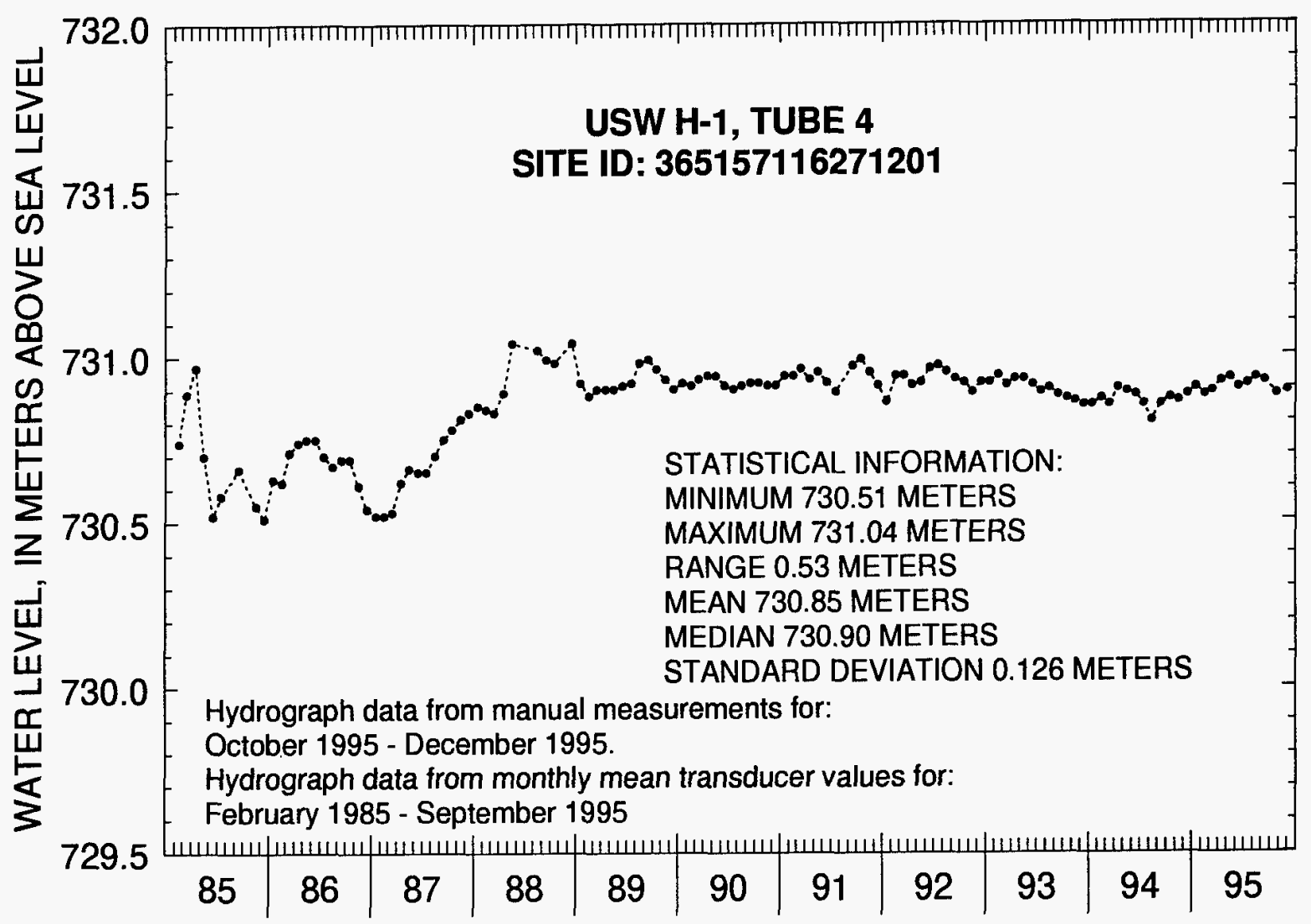

Figure 30. Water-level altitudes, 1985-95, for well USW H-1, tube 4.

\section{Well USW H-3, Upper Interval}

Water-level altitudes for well USW H-3, upper interval ranged from 731.07 to $731.93 \mathrm{~m}$ above sea level from 1985-95 (fig. 31). The mean annual water-level altitude for $1985-95$ was $731.52 \mathrm{~m}$ above sea level. The median value was $731.41 \mathrm{~m}$. Standard deviation was $0.287 \mathrm{~m}$. The annual mean water-level altitudes for 1985-95 are as follows:

\begin{tabular}{lc}
\hline Year & $\begin{array}{c}\text { Annual mean } \\
\text { water-level altitude } \\
\text { (meters) }\end{array}$ \\
\hline 1985 & 731.57 \\
1986 & 731.85 \\
1987 & 731.82 \\
1988 & 731.54 \\
1989 & 731.90 \\
1990 & 731.80 \\
1991 & 731.28 \\
1992 & 731.23 \\
1993 & 731.21 \\
1994 & 731.24 \\
1995 & 731.29 \\
\hline
\end{tabular}




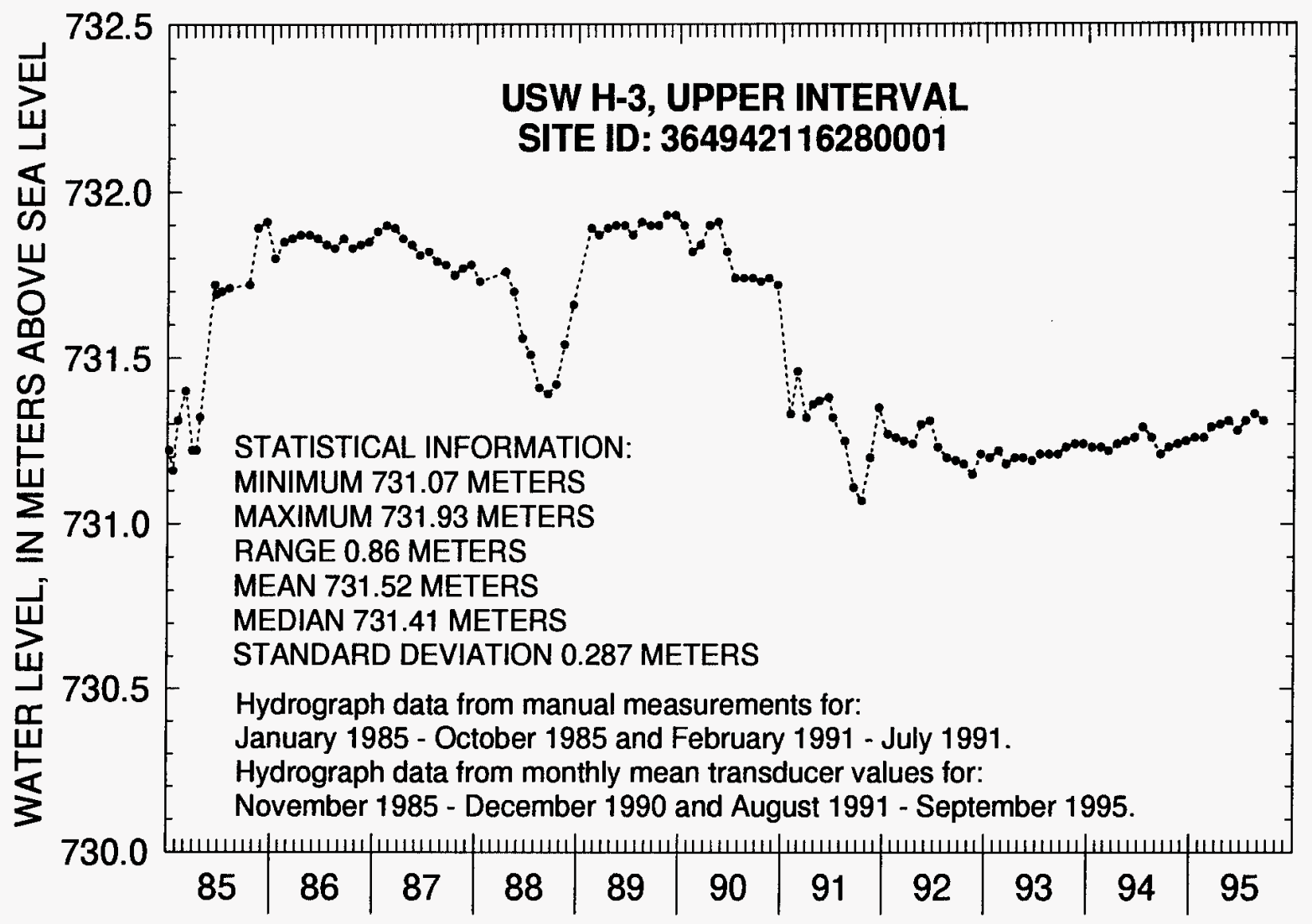

Figure 31. Water-level altitudes, 1985-95, for well USW H-3, upper interval.

Neither distinct seasonal trends in water-level changes or effects due to regional ground-water withdrawals were observed in well USW H-3, upper interval. Over the 11 years of record, there have been several abrupt water-level changes over relatively short timeframes. The rise in water level between April and June 1985, corresponds to a change in measuring equipment and probably was not the result of actual water-level changes (Robison and others, 1988). The decline and subsequent rise in water level from May 1988 through January 1989, coincides with the installation and removal of a transducer during the same months. The decline in water level between December 1990 and February 1991, corresponds to the removal and replacement of the packer, which separates the upper and lower interval. During December 1990 , the packer was moved from $1,114 \mathrm{~m}$ below land surface and replaced at $1,061 \mathrm{~m}$ below land surface. It may be that this water-level change reflects a vertical gradient in the well.

Because of so many abrupt water-level changes apparently due to change in monitoring equipment or to the replacement of the packer, long-term water-level rises and declines are not discussed. However, it should be noted that the December 1995 water level in well USW H-3, upper interval is within $0.09 \mathrm{~m}$ of the water level measured in the well during January 1985. To determine if there is a cyclic pattern to water-level changes in well USW H-3, upper interval, continuous long-term water-level data need to be collected. 


\section{Well USW H-3, Lower Interval}

Water-level altitude data are not available for well USW H-3, lower interval from 1985 through 1990. Water-level altitudes for well USW H-3, lower interval, ranged from 747.39 to $759.61 \mathrm{~m}$ above sea level from 1991-95 (fig. 32). The mean annual water-level altitude for 1991-95 was $755.91 \mathrm{~m}$ above sea level. The median value was $756.80 \mathrm{~m}$. Standard deviation was $3.098 \mathrm{~m}$. The annual mean waterlevel altitudes for 1991-95 are as follows:

\begin{tabular}{cc}
\hline Year & $\begin{array}{c}\text { Annual mean } \\
\text { water-level altitude } \\
\text { (meters) }\end{array}$ \\
\hline 1985 & Data not available \\
1986 & Data not available \\
1987 & Data not available \\
1988 & Data not available \\
1989 & Data not available \\
1990 & Data not available \\
1991 & 750.91 \\
1992 & 754.70 \\
1993 & 756.83 \\
1994 & 758.18 \\
1995 & 759.23 \\
\hline
\end{tabular}

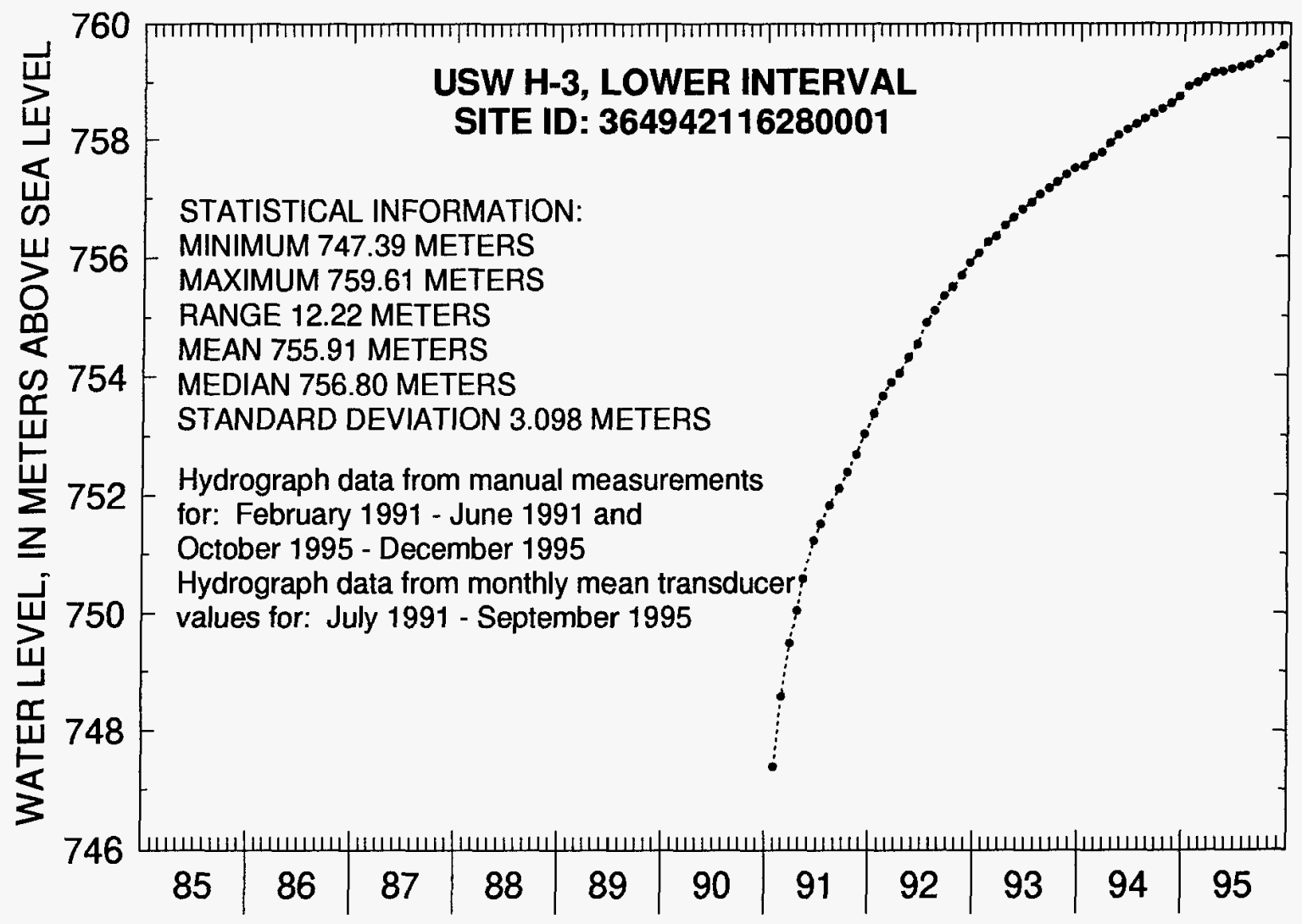

Figure 32. Water-level altitudes, 1985-95, for well USW H-3, lower interval. 
Water-level data for well USW H-3, lower interval are not available from 1985 through 1991. During May 1984, to separate the upper and lower interval, a packer was installed in the well to a depth of $1,114 \mathrm{~m}$. During December 1990, when the packer was removed for maintenance, it was discovered that the tube going through the packer to the lower zone had been plugged, and all water-level data collected from this interval were invalid. The tube was unplugged and the packer replaced to a depth of $1,061 \mathrm{~m}$ on December 14, 1990.

Neither distinct seasonal trends in water-level changes or effects due to regional ground-water withdrawals were observed in well USW H-3, lower interval. Over the 5 years of available record from 1991-95, the water-level in well USW H-3, lower interval has continued to rise to a new static water level in the process of reaching equilibrium (O'Brien and others, 1995). The reason for the slow rise in water level over a 5-year period could be because the tube is completed in a zone of very low hydraulic conductivity.

\section{Well USW H-4, Upper Interval}

Water-level altitudes for well USW H-4, upper interval ranged $0.32 \mathrm{~m}$ from 730.20 to $730.52 \mathrm{~m}$ above sea level from 1985-95 (fig. 33). The mean annual water-level altitude for 1985-95 was $730.40 \mathrm{~m}$ above sea level. The median value was $730.40 \mathrm{~m}$. Standard deviation was $0.061 \mathrm{~m}$. The annual mean water-level altitudes for 1985-95 are as follows:

\begin{tabular}{cc}
\hline Year & $\begin{array}{c}\text { Annual mean } \\
\text { water-level altitude } \\
\text { (meters) }\end{array}$ \\
\hline 1985 & 730.29 \\
1986 & 730.34 \\
1987 & 730.43 \\
1988 & 730.35 \\
1989 & 730.38 \\
1990 & 730.41 \\
1991 & 730.49 \\
1992 & 730.45 \\
1993 & 730.41 \\
1994 & 730.39 \\
1995 & 730.38 \\
\hline
\end{tabular}

Neither distinct seasonal trends in water-level changes or effects due to regional ground-water withdrawals were observed in well USW H-4, upper interval. Most water-level changes can be attributed to barometric and Earth-tide changes. In terms of long-term trends, over the 11 years of record, there is a slight rise in water level from February 1985 through March 1992, followed by a slight decline in water level from April 1992 through December 1995. 


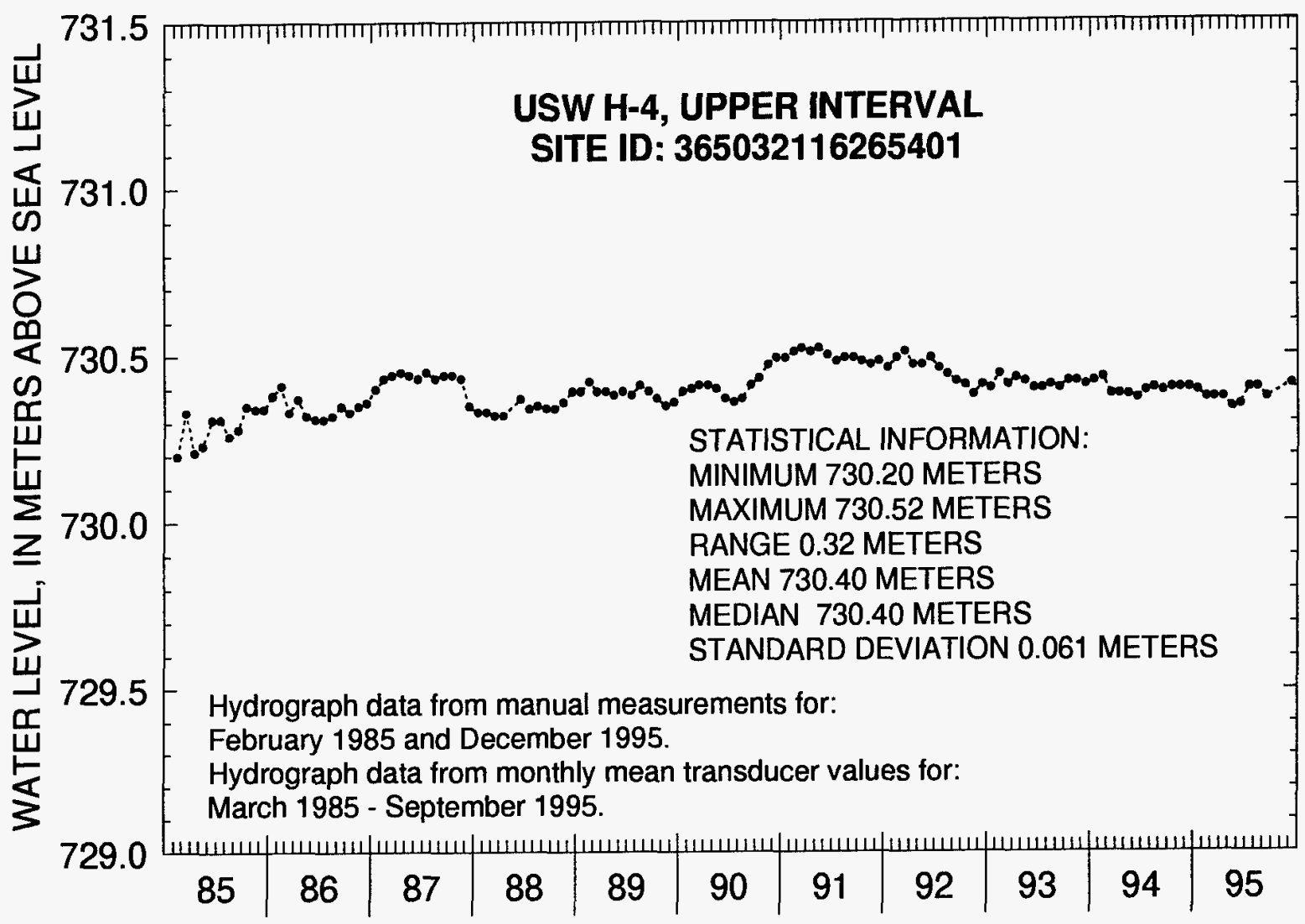

Figure 33. Water-level altitudes, 1985-95, for well USW H-4, upper interval.

\section{Well USW H-4, Lower Interval}

Water-level altitudes for well USW H-4, lower interval ranged $0.65 \mathrm{~m}$ from 730.18 to $730.83 \mathrm{~m}$ above sea level from 1985-95 (fig. 34). The mean annual water-level altitude for 1985-95 was $730.52 \mathrm{~m}$ above sea level. The median value was also $730.51 \mathrm{~m}$. Standard deviation was $0.108 \mathrm{~m}$. The annual mean water-level altitudes for 1985-95 are as follows:

\begin{tabular}{cc}
\hline Year & $\begin{array}{c}\text { Annual mean } \\
\text { water-level altitude } \\
\text { (meters) }\end{array}$ \\
\hline 1985 & 730.35 \\
1986 & 730.45 \\
1987 & 730.51 \\
1988 & 730.40 \\
1989 & 730.61 \\
1990 & 730.60 \\
1991 & 730.56 \\
1992 & 730.58 \\
1993 & 730.53 \\
1994 & 730.49 \\
1995 & 730.50 \\
\hline
\end{tabular}




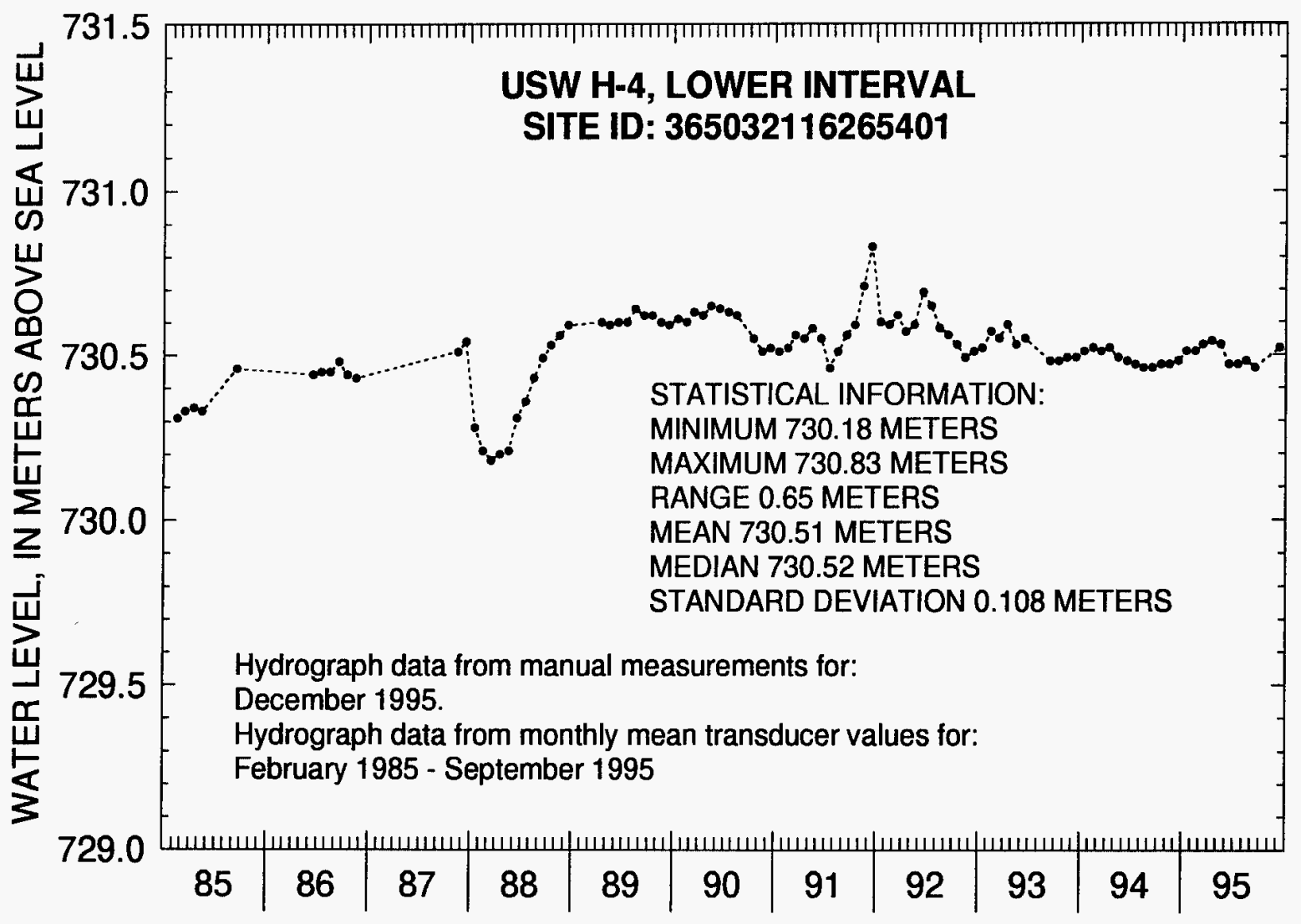

Figure 34. Water-level altitudes, 1985-95, for well USW H-4, lower interval.

Neither distinct seasonal trends in water-level changes or effects due to regional ground-water withdrawals were observed in well USW H-4, lower interval. Over the 11 years of record, there were several periods of abrupt water-level changes over relatively short timeframes preceded and followed by moderate water-level changes attributed to barometric and Earth-tide changes. Overall, there was a slight rise in water level from February 1985 through May 1990. This was followed by a slight decline in water level from June 1990 through December 1995. To determine if there is a cyclic pattern to water-level changes in well USW H-4, lower interval, continuous long-term water-level data need to be collected.

\section{Well USW H-5, Upper Interval}

Water-level altitudes for well USW H-5, upper interval ranged from 774.96 to $775.72 \mathrm{~m}$ above sea level from 1985-95 (fig. 35). The mean annual water-level altitude for 1985-95 was $775.46 \mathrm{~m}$ above sea level. The median value was also $775.47 \mathrm{~m}$. Standard deviation was $0.139 \mathrm{~m}$. The annual mean waterlevel altitudes for 1985-95 are as follows: 


\begin{tabular}{ll}
\hline Year & $\begin{array}{c}\text { Annual mean } \\
\text { water-level altitude } \\
\text { (meters) }\end{array}$ \\
\hline 1985 & 775.18 \\
1986 & 775.42 \\
1987 & 775.50 \\
1988 & 775.47 \\
1989 & 775.49 \\
1990 & 775.41 \\
1991 & 775.43 \\
1992 & 775.65 \\
1993 & 775.59 \\
1994 & 775.48 \\
1995 & 775.40 \\
\hline
\end{tabular}

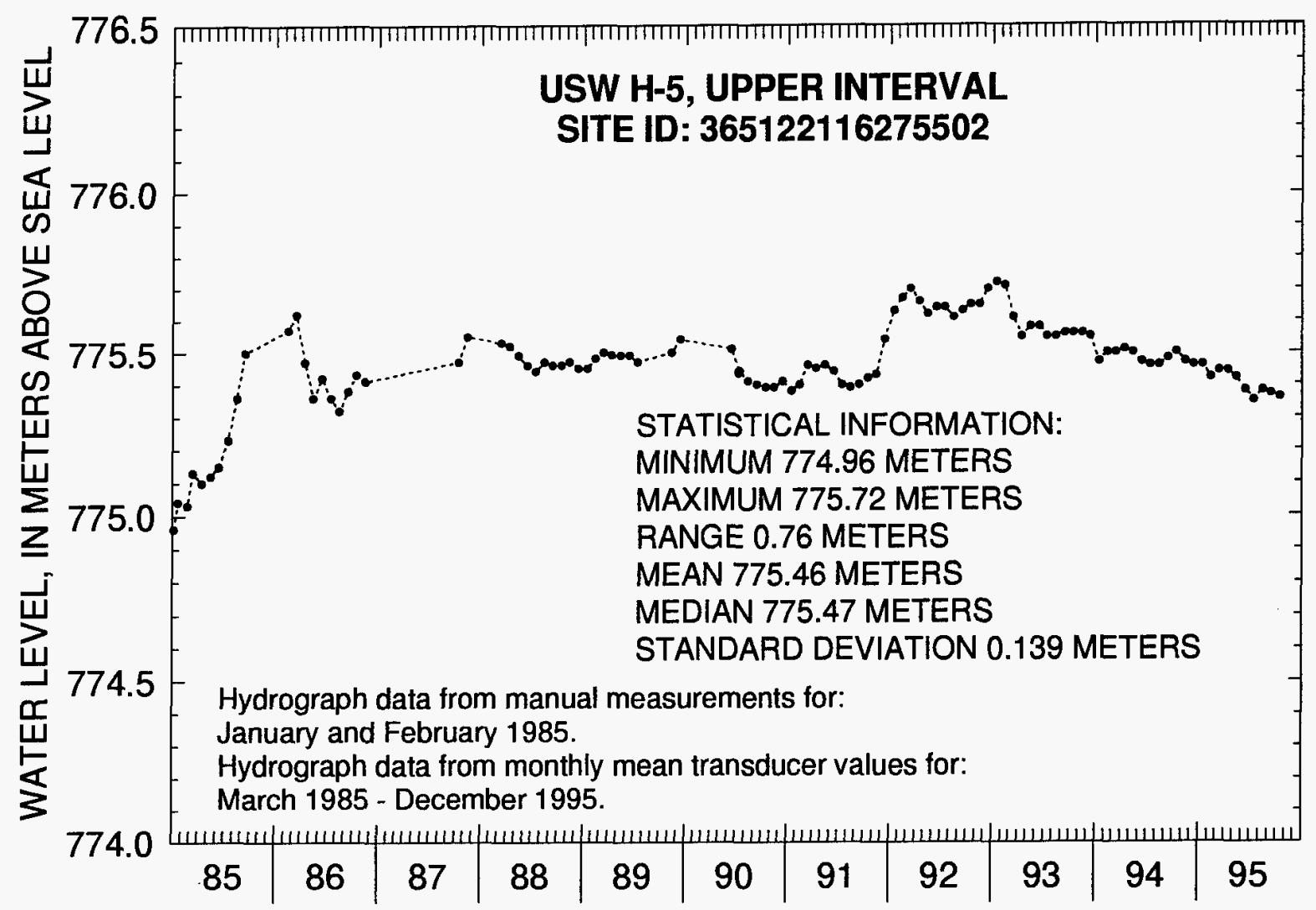

Figure 35. Water-level altitudes, 1985-95, for well USW H-5, upper interval.

Neither distinct seasonal trends in water-level changes or effects due to regional ground-water withdrawals were observed in well USW H-5, upper interval. Most water-level changes can be attributed to barometric and Earth-tide changes. Over the 11 years of record, there is a rise in water level from January 1985 through January 1993, followed by a decline in water level from February 1993 through December 1995. 


\section{Well USW H-5, Lower Interval}

Water-level altitudes for well USW H-5, lower interval ranged from 774.95 to $775.86 \mathrm{~m}$ above sea level from 1985-95 (fig. 36). The mean annual water-level altitude for 1985-95 was $775.62 \mathrm{~m}$ above sea level. The median value was $775.64 \mathrm{~m}$. Standard deviation was $0.186 \mathrm{~m}$. The annual mean water-level altitudes for 1985-95 are as follows:

\begin{tabular}{cc}
\hline Year & $\begin{array}{c}\text { Annual mean } \\
\text { water-level altitude } \\
\text { (meters) }\end{array}$ \\
\hline 1985 & 775.06 \\
1986 & Data not available \\
1987 & 775.46 \\
1988 & Data not available \\
1989 & Data not available \\
1990 & 775.60 \\
1991 & 775.65 \\
1992 & 775.55 \\
1993 & 775.76 \\
1994 & 775.65 \\
1995 & 775.78 \\
\hline
\end{tabular}

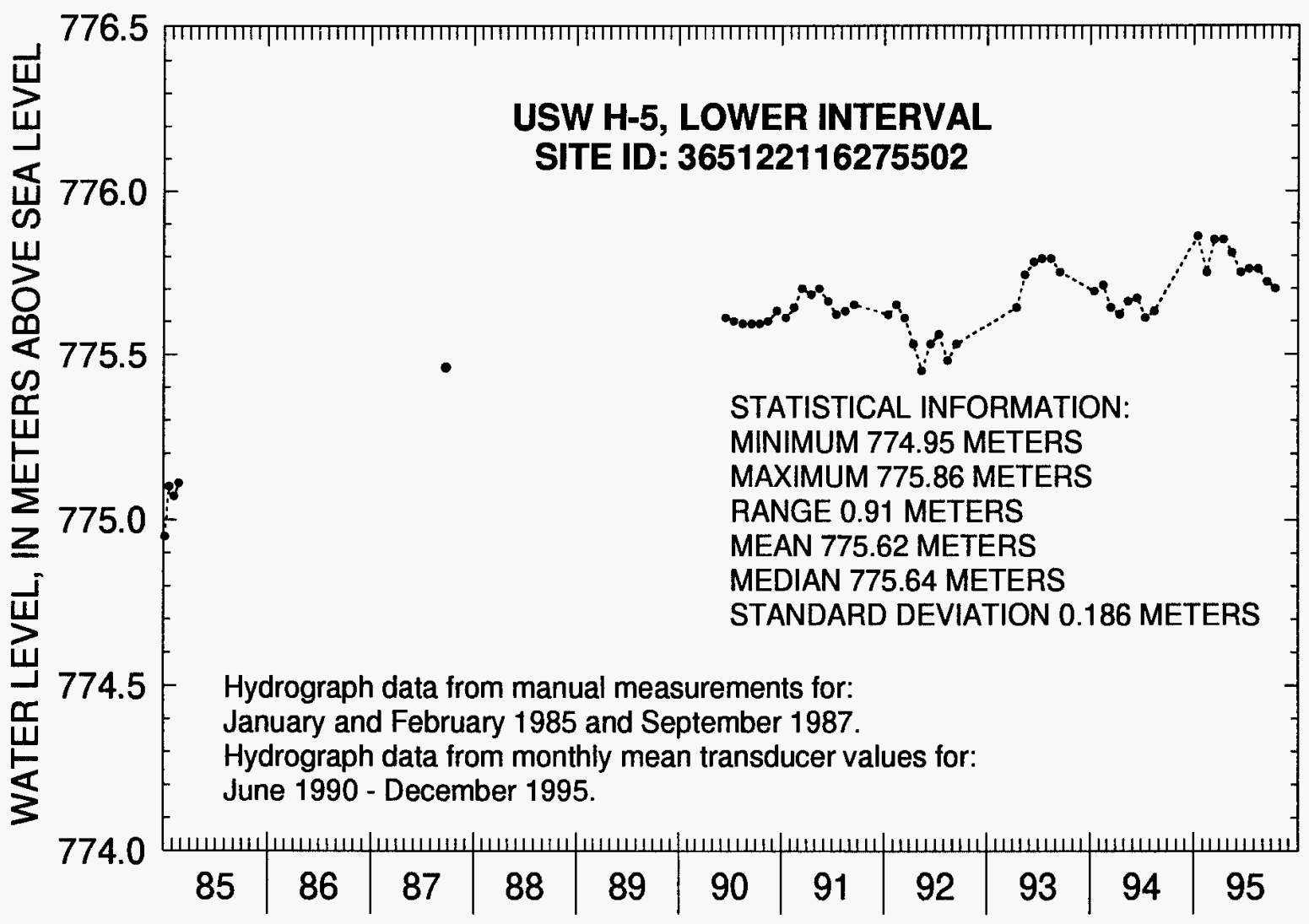

Figure 36. Water-level altitudes, 1985-95, for well USW H-5, lower interval. 
Neither distinct seasonal trends in water-level changes or effects due to regional ground-water withdrawals were observed in well USW H-5, lower interval. Water-level data was not available for 1986, 1988 , or 1989, because of transducer failure in the well. Over the 8 years of available record there is a general rise in water level in well USW H-5, lower interval. What little changes that are seen in the water table are probably due to barometric and Earth-tide changes.

\section{Well USW H-6, Upper Interval}

Water-level altitudes for well USW H-6, upper interval ranged from 775.83 to $776.20 \mathrm{~m}$ above sea level from 1985-95 (fig. 37). The mean annual water-level altitude for $1985-95$ was $776.02 \mathrm{~m}$ above sea level. The median value was $776.03 \mathrm{~m}$. Standard deviation was $0.087 \mathrm{~m}$. The annual mean water-level altitudes for 1985-95 are as follows:

\begin{tabular}{cc}
\hline Year & $\begin{array}{c}\text { Annual mean } \\
\text { water-level altitude } \\
\text { (meters) }\end{array}$ \\
\hline 1985 & 775.96 \\
1986 & 776.10 \\
1987 & 776.05 \\
1988 & 775.95 \\
1989 & 775.90 \\
1990 & 775.93 \\
1991 & 775.99 \\
1992 & 776.02 \\
1993 & 776.07 \\
1994 & 776.11 \\
1995 & 776.13 \\
\hline
\end{tabular}

Neither distinct seasonal trends in water-level changes or effects due to regional ground-water withdrawals were observed in well USW H-6, upper interval. Most water-level changes can be attributed to barometric and Earth-tide changes. Over the 11 years of record, there is a rise in water level from August 1985 through February 1987, followed by a decline in water level from March 1987 through May 1989, and then another rise in water level from June 1989 through December 1995. To determine if this is a cyclic pattern, continuous long-term water-level data need to be collected. 


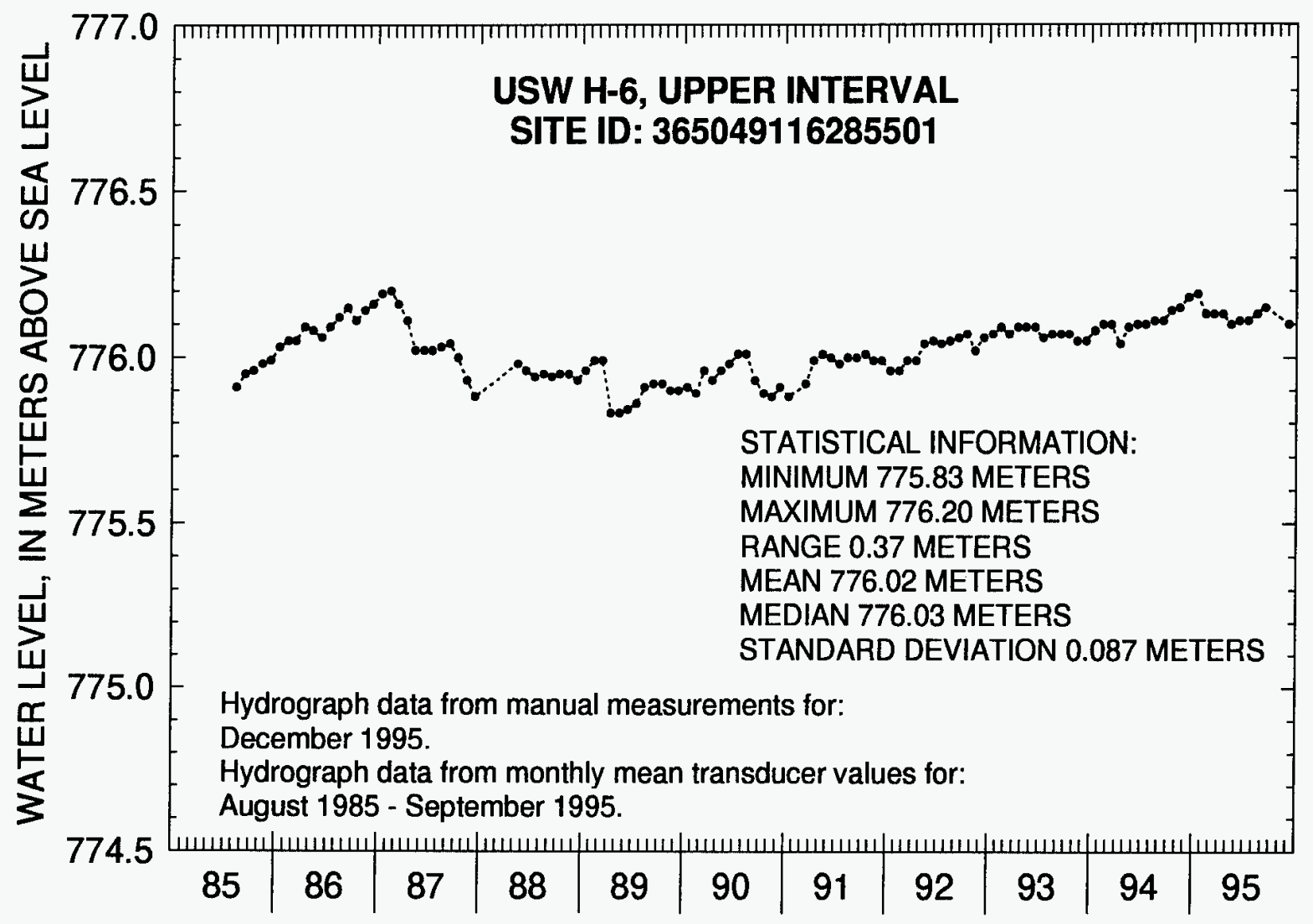

Figure 37. Water-level altitudes, 1985-95, for well USW H-6, upper interval.

\section{Well USW H-6, Lower Interval}

Water-level altitude data are not available for well USW H-6, lower interval from 1985-87. Waterlevel altitudes for well USW H-6, lower interval ranged from 775.71 to $776.08 \mathrm{~m}$ above sea level from 1988-95 (fig. 38). The mean annual water-level altitude for 1988-95 was $775.94 \mathrm{~m}$ above sea level. The median value was $775.95 \mathrm{~m}$. Standard deviation was $0.070 \mathrm{~m}$. The annual mean water-level altitudes for 1988-95 are as follows:

\begin{tabular}{cc}
\hline Year & $\begin{array}{c}\text { Annual mean } \\
\text { water-level altitude } \\
\text { (meters) }\end{array}$ \\
\hline 1985 & Data not available \\
1986 & Data not available \\
1987 & Data not available \\
1988 & 775.89 \\
1989 & 775.93 \\
1990 & 775.89 \\
1991 & 775.91 \\
1992 & 775.93 \\
1993 & 775.97 \\
1994 & 775.99 \\
1995 & 776.01 \\
\hline
\end{tabular}




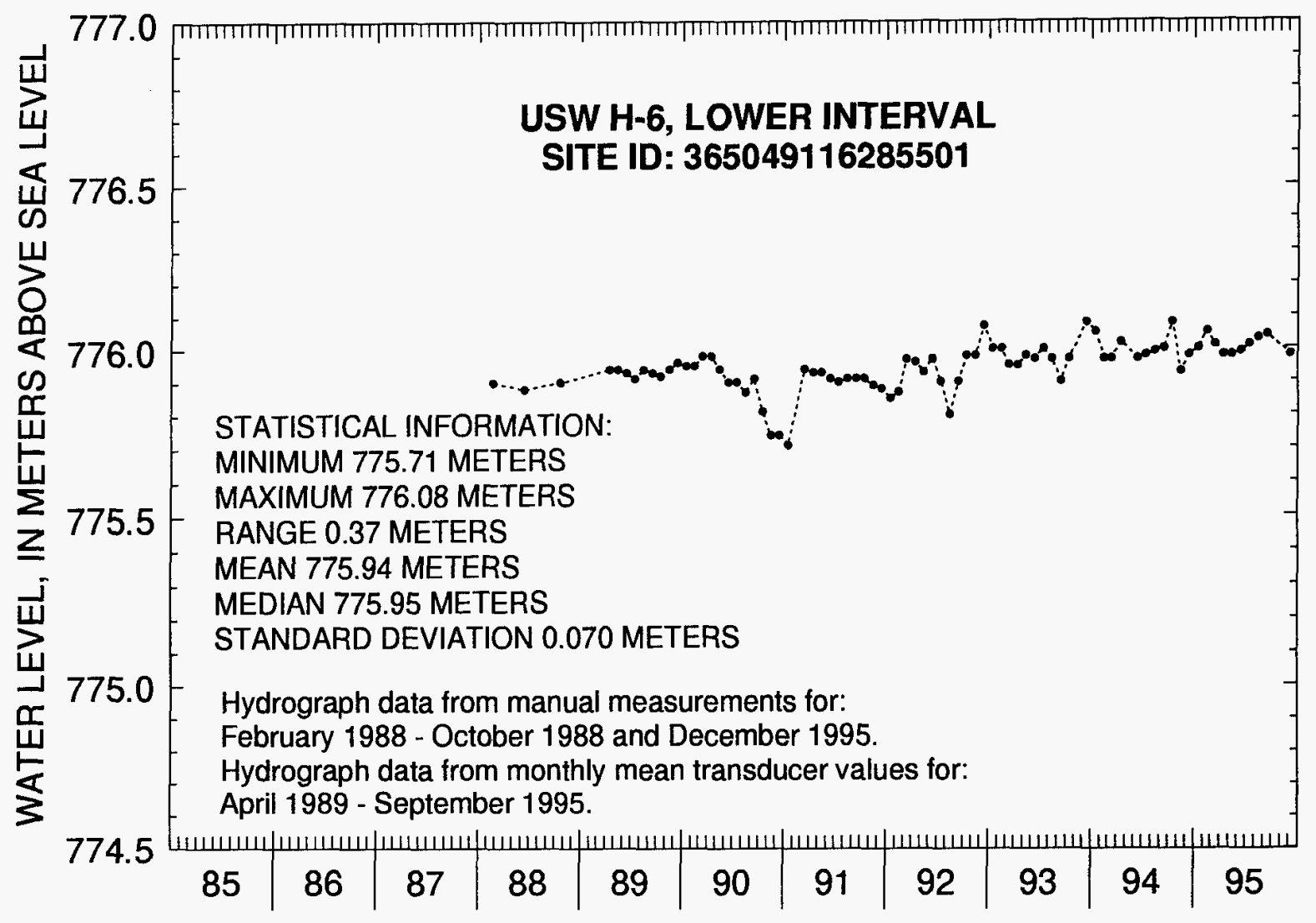

Figure 38. Water-level altitudes, 1985-95, for well USW H-6, lower interval.

Neither distinct seasonal trends in water-level changes or effects due to regional ground-water withdrawals were observed in well USW H-6, lower interval. Most water-level changes can be attributed to barometric and Earth-tide changes. Though slight, over the 8 years of record, there is a gradual rise in water level from 1988-95. Water-level data for 1985 through December 1987 for well USW H-6, lower interval are not available because of questionable transducer data.

\section{WATER-LEVEL TRENDS}

Historically, several reports have been written that discuss trends in ground-water water-level changes in the Yucca Mountain area (Lehman and others, 1990; Ervin and others, 1994; Tucci and Burkhardt, 1995). These reports discuss the following:

\section{Lehman and others (1990):}

The authors analyzed 1981-87 periodic water-level data to determine if the data contained periodic (cosine) components. The authors concluded that there may be periodic components of 2- to 3-year periods in the fluctuation of the ground-water levels. The authors also state that the periodic behavior had a spatial distribution, with wells west of Yucca Mountain having different periods and phase shifts from wells on and east of Yucca Mountain. This relation of spatial distribution was compared to the findings of Matuska (1988), who discussed a similar spatial distribution of ground-water chemistry. Making this comparison, Lehman and others (1990) suggest that the spatial distribution may be due to physical causes and the periodic fluctuations may be due to periodic recharge related to a periodicity in precipitation. 


\section{Ervin and others (1994):}

The authors published a revised potentiometric-surface map and analyzed water-level data collected from 1986-89. Water-level trends were analyzed by a linear least-squares regression of time and water level. The authors concluded that water-level data from 5 of 23 wells analyzed exhibited apparent trends that were both statistically and hydrologically significant. These wells (UE-25 WT-2, UE-25 WT\#6, UE-25 WT\#16, UE-25 p\#1, and USW H-5) all had apparent positive trends. The remaining wells analyzed displayed no trend.

\section{Tucci and Burkhardt (1995):}

The authors published a potentiometric-surface map of 1993 water levels and analyzed water-level data collected from 1986-93. Water-level trends were also analyzed by a linear least-squares regression of time and water level. The authors concluded that water-level data from 3 of 22 wells analyzed exhibited apparent trends that were statistically significant. These wells (UE-25 WT\#3, USW WT-7, and USW WT-10) all had apparent positive trends. The remaining wells had no trend. Of note, neither Ervin and others (1994) nor Tucci and Burkhardt (1995) found the same wells to have positive trends.

For the wells presented in this report, hydrographs have been completed and periods of rising, declining, or stable water levels have been discussed for the 1985-95 water-level data. However, in comparing these hydrographs, few uniform water-level trends were detected. The most significant trend noted was the effect on water-level changes caused by the June 28-29, 1992 earthquakes.

Wells and well intervals thought to be affected by the June 28-29, 1995, earthquakes are UE-25 WT\#4, UE-25 WT\#6, USW WT-11, UE-25 WT\#12, UE-25 WT\#16, UE-25 b\#1 upper interval, and UE-25 p\#1 (fig. 39). Because of the magnitude and abrupt change in water level in wells UE-25 WT\#4, UE-25 WT\#6, and UE-25 p\#1, these wells probably were definitely affected by the earthquakes; however, there is no consistency in the pattern of water-level change in these wells. In well UE-25 WT\#4, the water-level rises about $0.25 \mathrm{~m}$ (730.92 m, 06-25-92 to $731.17 \mathrm{~m}, 07-15-92$, Appendix B) and then declines back to a water level consistent with levels prior to the earthquakes $(730.83 \mathrm{~m}, 08-10-92)$. These water-level changes occurred within about 42 days of the earthquakes.

In well UE-25 WT\#6, there is a maximum rise in water level of about $1.07 \mathrm{~m}(1,035.02 \mathrm{~m}$, 06-23-92, to 1,036.09 m, 07-17-92, Appendix B) followed by a decline in water level of about $2.66 \mathrm{~m}$ $(1,036.09 \mathrm{~m}, 07-17-92$, to $1,034.33 \mathrm{~m}, 09-22-92)$. These water-level changes occurred within about 85 days of the earthquake. The water level continued to decline in well UE-25 WT\#6 (0.07 m more) through October 16, 1992. However, because the water level in this well never recovered to the levels in the well prior to the earthquake, it is believed that water-level changes after September 22, 1992, are normal fluctuations in the well after it reached its new equilibrium.

In well UE-25 p\#1, the water level declined about $0.53 \mathrm{~m}(752.44 \mathrm{~m}, 06-28-92$, to $751.91 \mathrm{~m}$, 07-08-92 ${ }^{1}$. Following this, the water level in well UE-25 $\mathrm{p} \# 1$ began to rise and had fully recovered from the effects of the earthquakes by December 7, 1992 (water level of $752.44 \mathrm{~m}^{2}$ ). This complete cycle of water-level changes occurred within about 191 days of the earthquake.

The water-level change in well USW WT-11 is also thought to be due to the earthquakes. However, because of the gradual change in water level, it is not known if the 9-month cycle following the earthquake is just coincidental or actually due to the earthquakes. In well USW WT-11, the water level declines slowly following the earthquake from July through November 1992, with a maximum change in water level of $0.24 \mathrm{~m}(730.72 \mathrm{~m}, 06-28-92$, to $730.48 \mathrm{~m}, 11-26-92)$. Following this low, the water level

\footnotetext{
${ }^{1}$ Comparative data for well UE-25 $\mathrm{p} \# 1$ are the daily mean values that were obtained from the U.S. Geological Survey data base and used to calculate monthly mean values that are shown in Appendix B.
} 


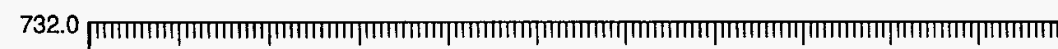

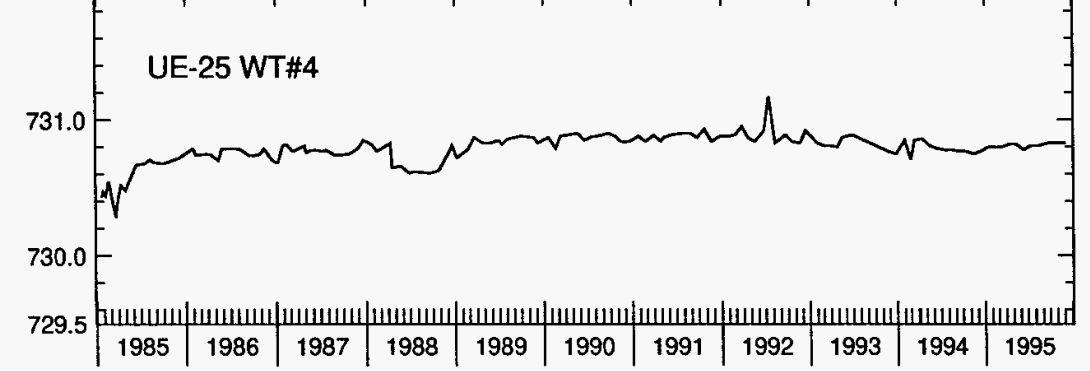

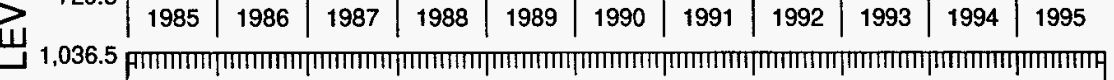
$\varangle 1,036.0$

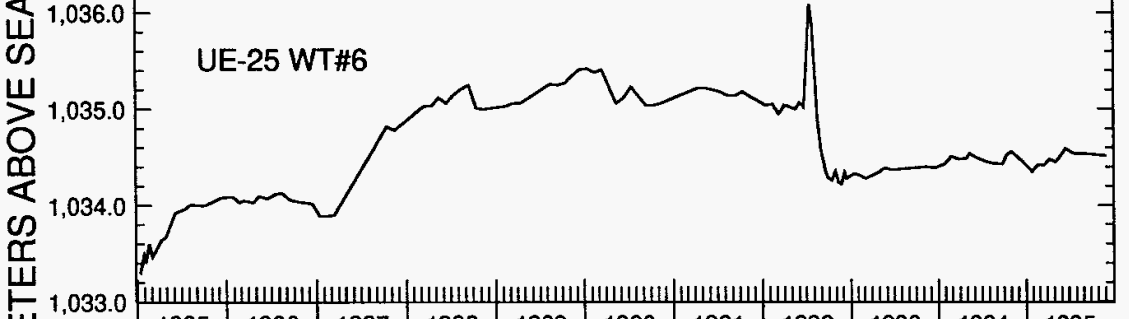

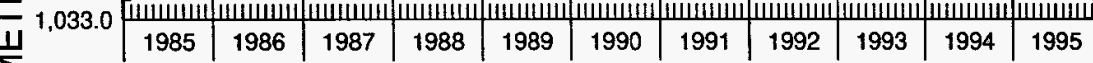

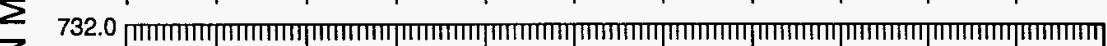

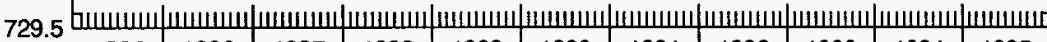
\begin{tabular}{l|l|l|l|l|l|l|l|l|l|l|}
1985 & 1986 & 1987 & 1988 & 1989 & 1990 & 1991 & 1992 & 1993 & 1994 & 1995
\end{tabular}

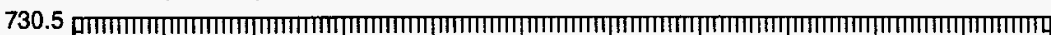

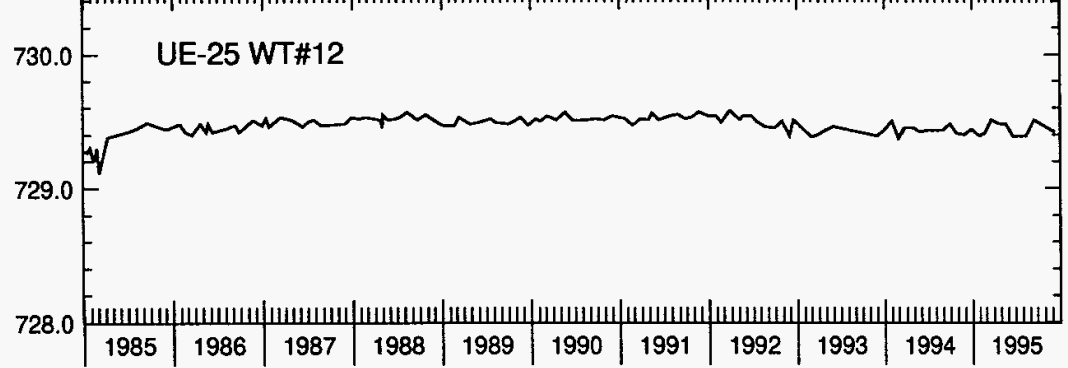

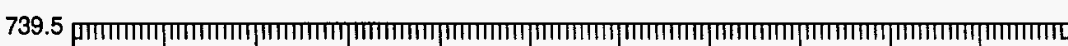

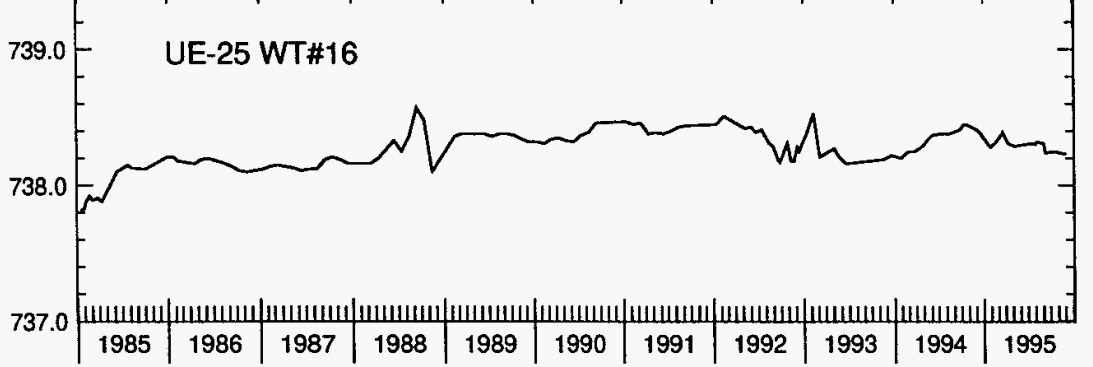

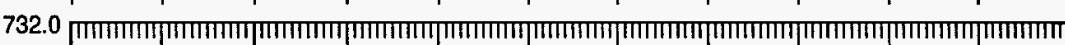

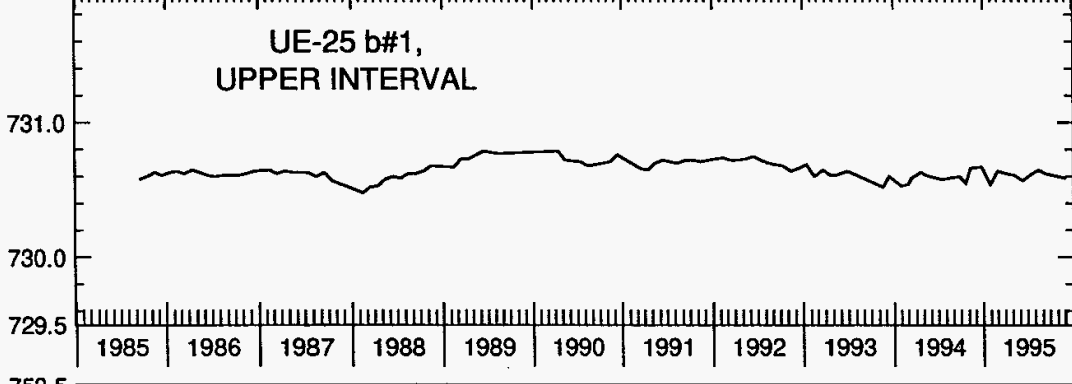

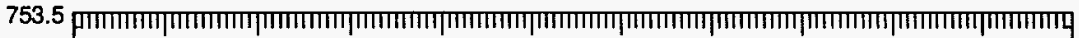

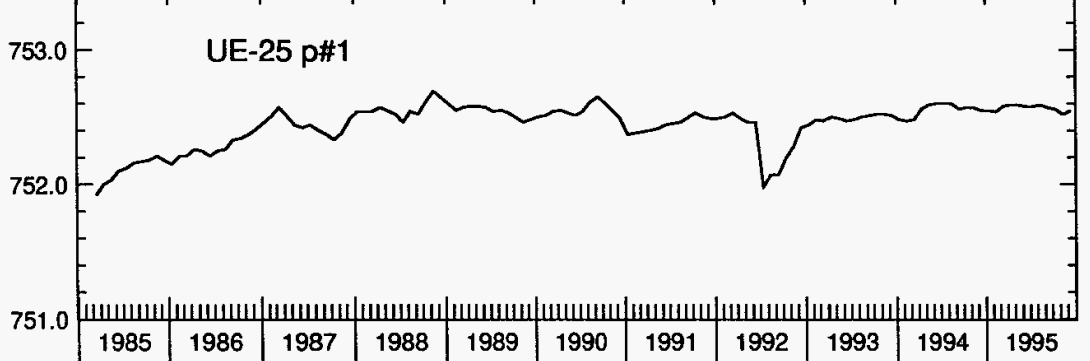

Figure 39. Water-level altitudes, 1985-95, for wells that may have been affected by the June 1992 earthquakes. (Hydrographs plotted as continuous data. Refer to "WATER LEVELS, 1985-95" section of report for data collection frequency of each well) 
slowly rises back to a level consistent with levels prior to the earthquake by April 5, 1993 (730.72 m). This whole cycle of decline and rise in water level occurred within about 9 months of the earthquake (July 1992 through March $1993^{2}$ ).

In wells UE-25 WT\#12, UE-25 WT\#16, and UE-25 b\#1, the water-level change observed during July 1992 following the earthquakes is minimal, either rising or declining slightly in each well (Appendix B). These water-level changes are within the normal month-to-month changes seen in all wells and would not warrant mention here if not for the overall water-level trend seen in each well after the earthquake. Regardless of whether there was an immediate rise or decline in the water levels following the earthquakes, the trend in each of these wells was an overall steady decline in the water level after July 1992, which has continued through December 1995. Because similar trends of declining water levels are seen in other wells that do not coincide with the earthquakes, it is not known if the shift in direction of water movement in these three wells is directly due to the earthquakes or is nothing more than coincidence, with the trend in decline in water level occurring regardless of the earthquake activity.

Well hydrographs were compared to determine if trends in water-level change could be related to wells completed in the same general area (figs. 40-42) or with the same general water-table altitude (figs. 43-45). With the exception of wells located in Crater Flat (fig. 42), no consistent water-level changes could be seen between any two wells. The most comparable wells in Crater Flat are wells USW WT-7 and USW WT-10 (wells which also have similar water-level altitudes in the 776-m range, fig. 45). Water-level fluctuations in these two wells have similar patterns from February 1989 through July 1992. Vague similarities can also be seen between wells USW VH-1 and USW WT-7 from September 1986 through February 1987 and from June 1993 through January 1994. However, these similarities are not as continuous or striking as those seen between USW WT-7 and USW WT-10.

${ }^{2}$ Comparative data for well USW WT-11 are the daily mean values that were obtained from the U.S. Geological Survey data base and used to calculate the monthly mean values that are shown in Appendix B. 


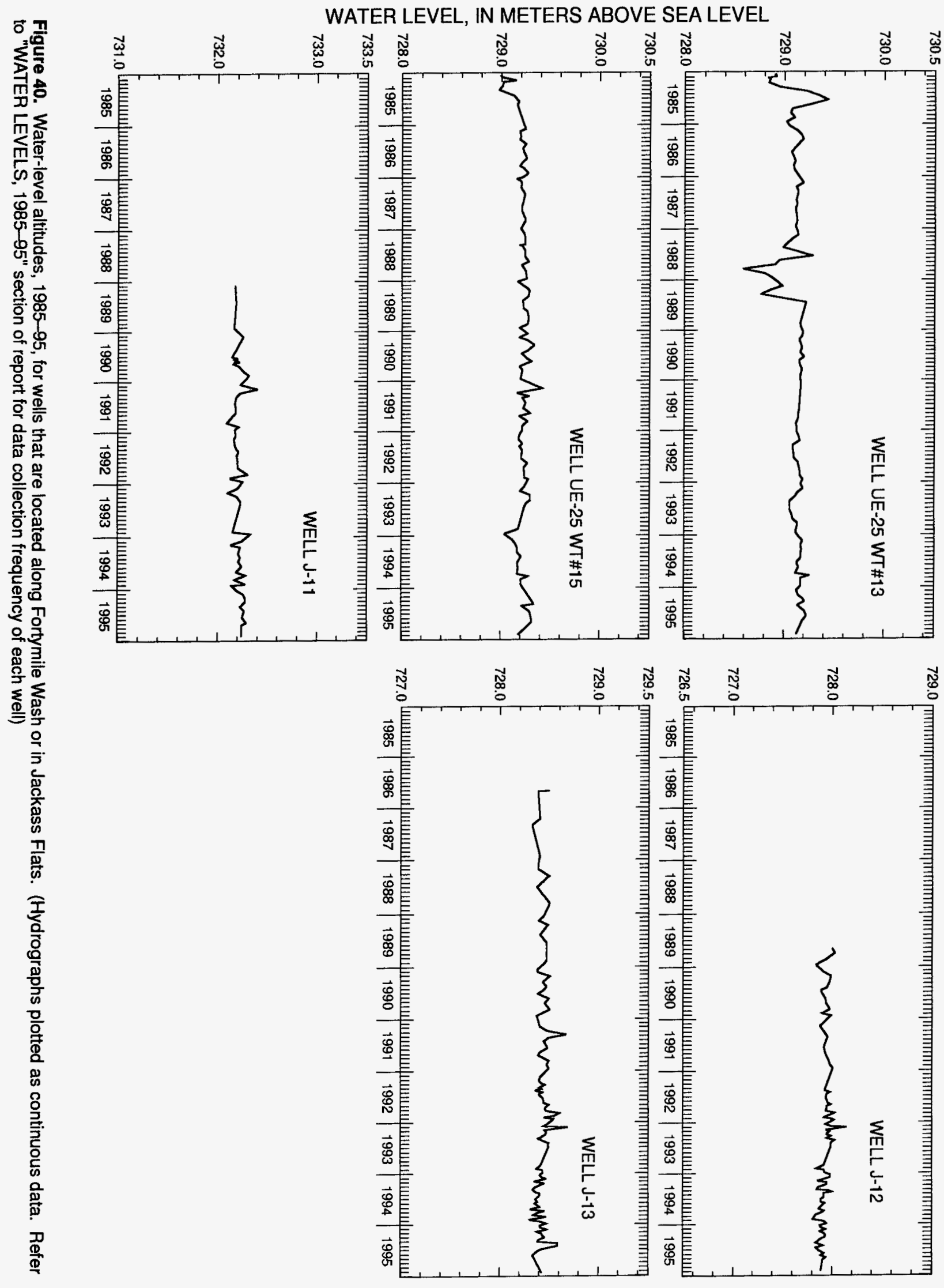




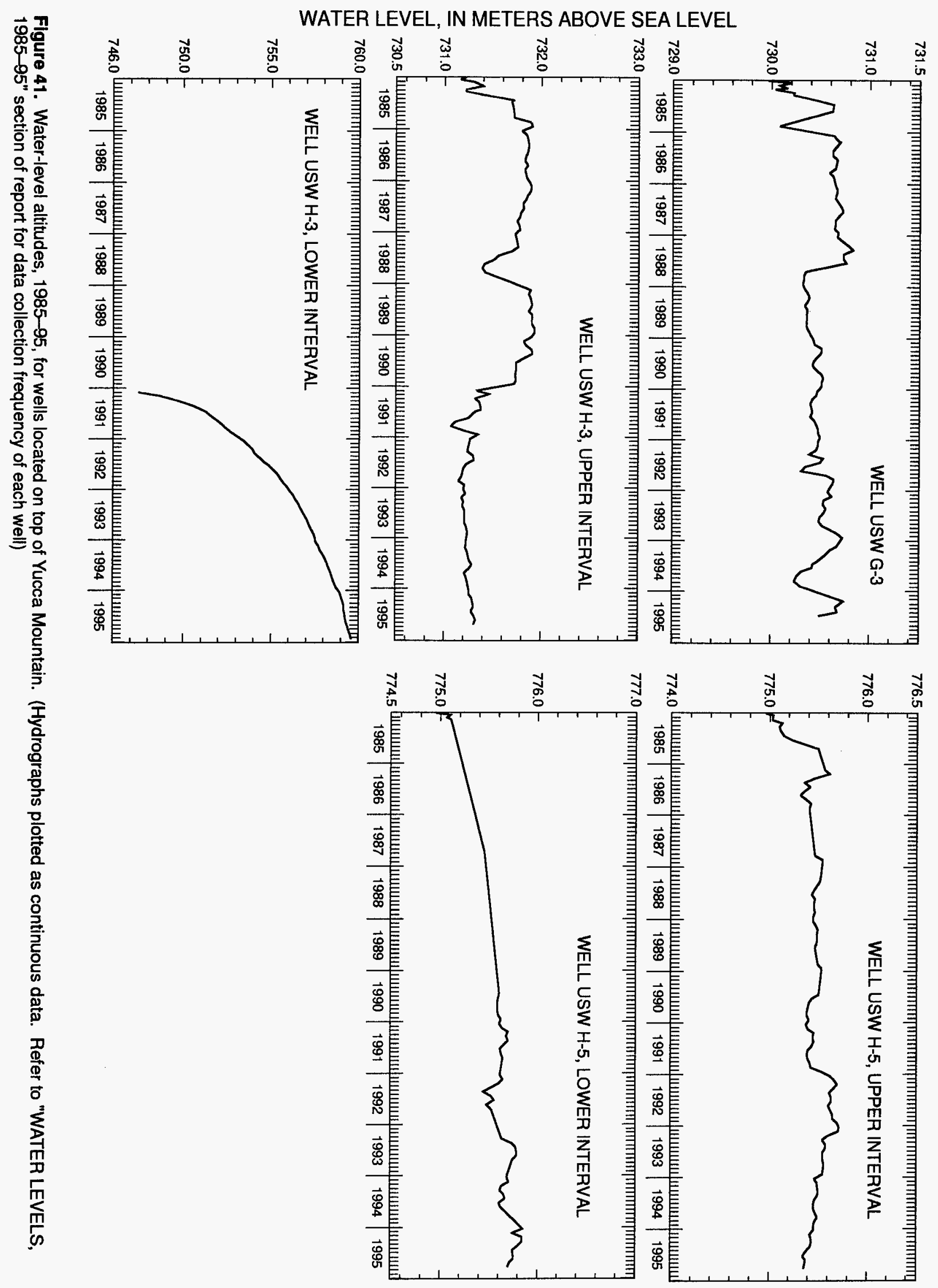




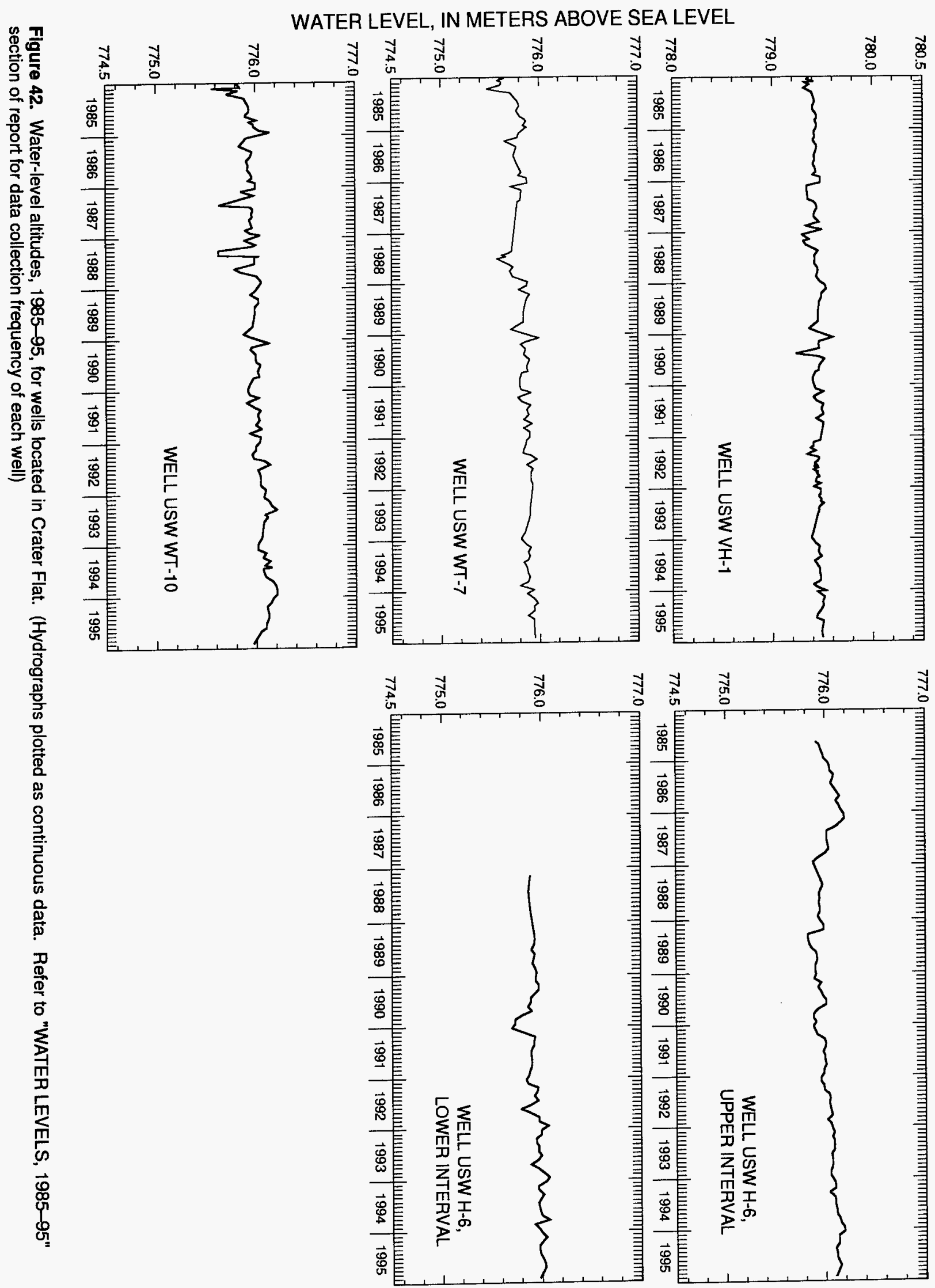



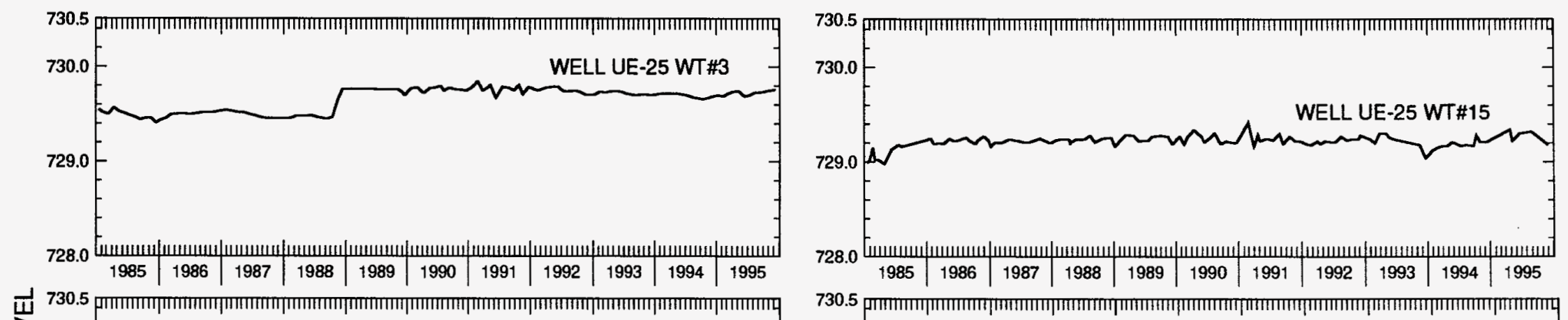

$$
\text { 崖 }
$$

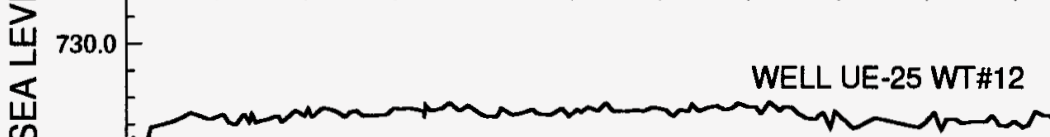

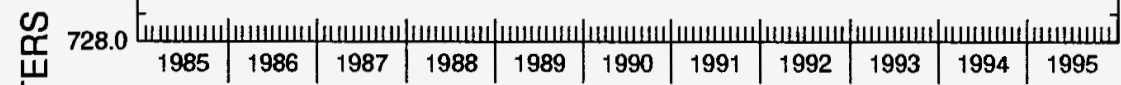

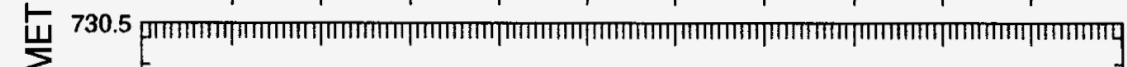

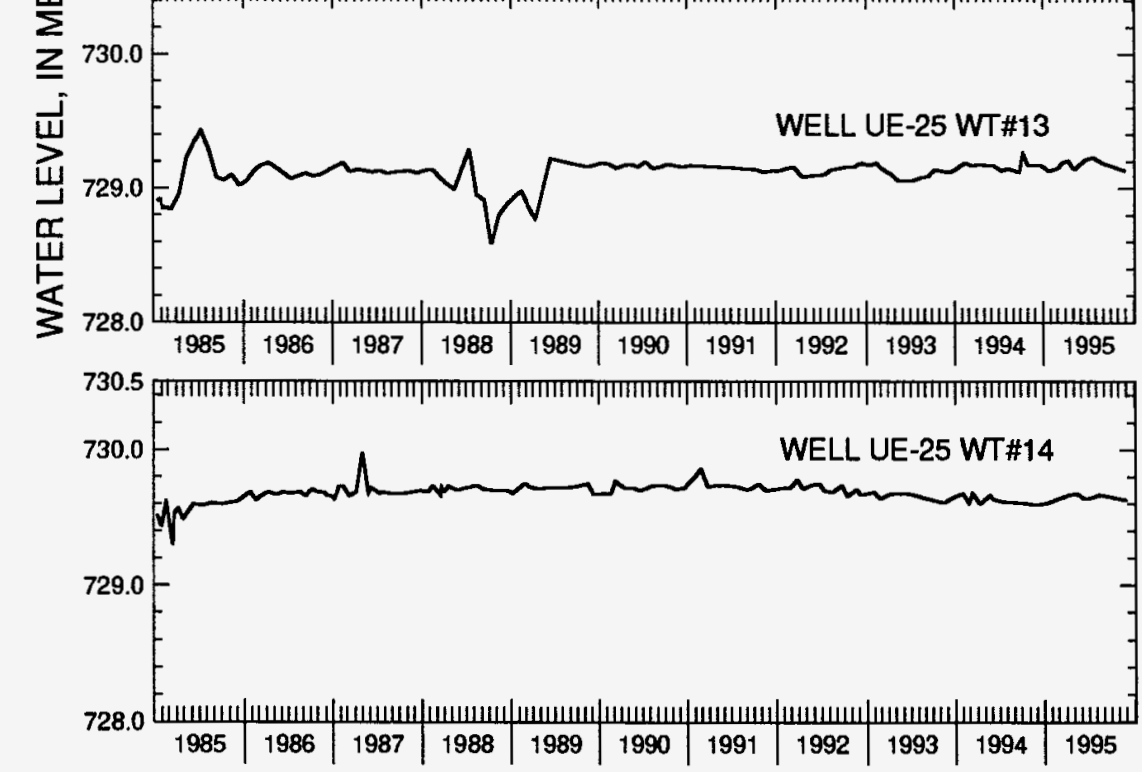

730.5 ExाTाTाTा|

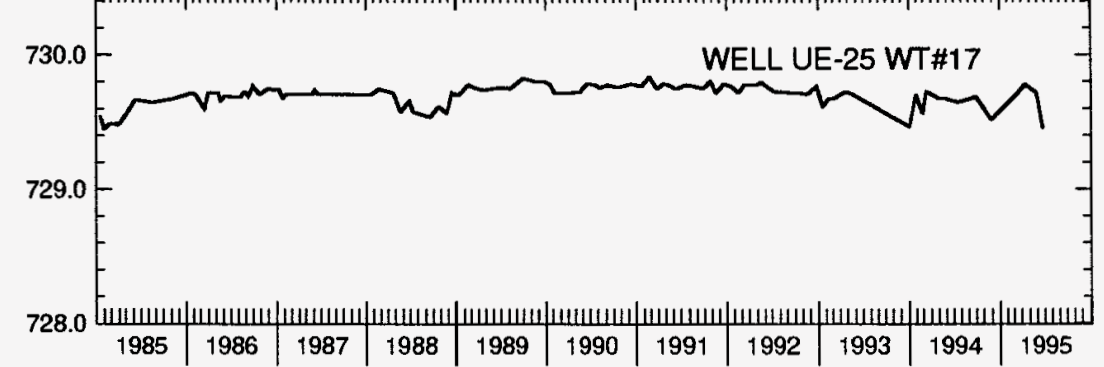

730.5 PाTाTाTा|

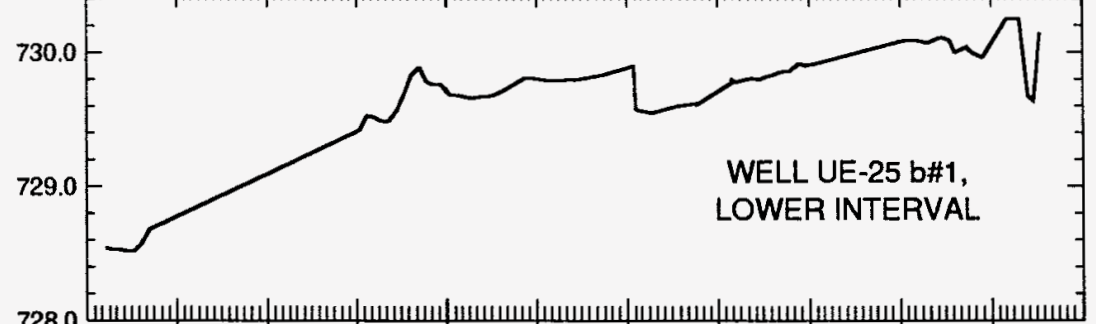

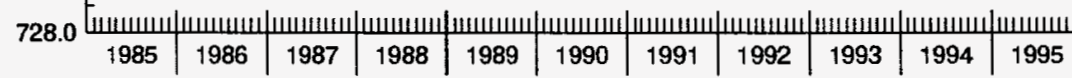

Figure 43. Water-level altitudes, 1985-95, for wells with an approximate water-level altitude of 729 meters. (Hydrographs plotted as continuous data. Refer to "WATER LEVELS, 1985-95" section of report for data collection frequency of each well) 


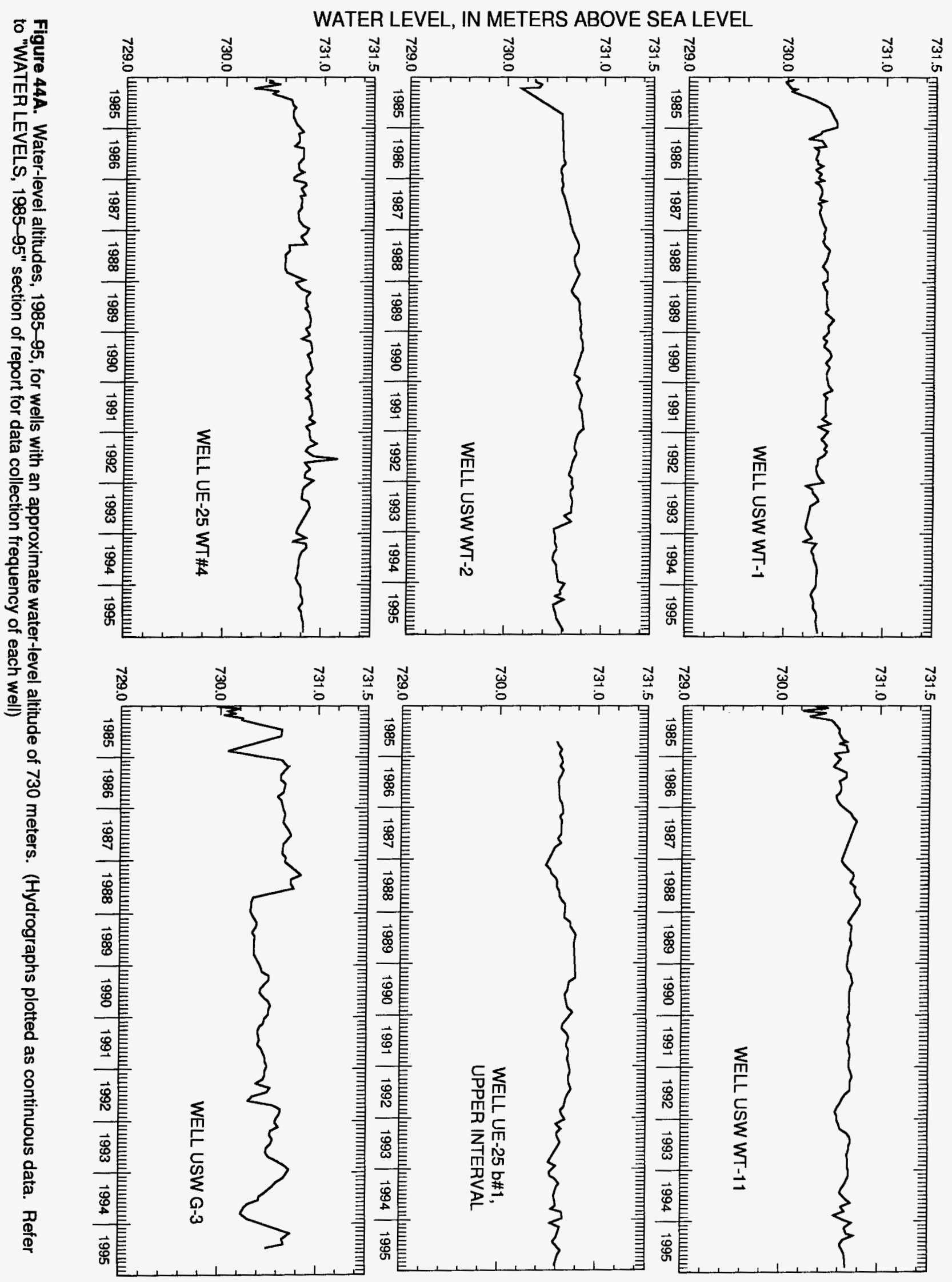




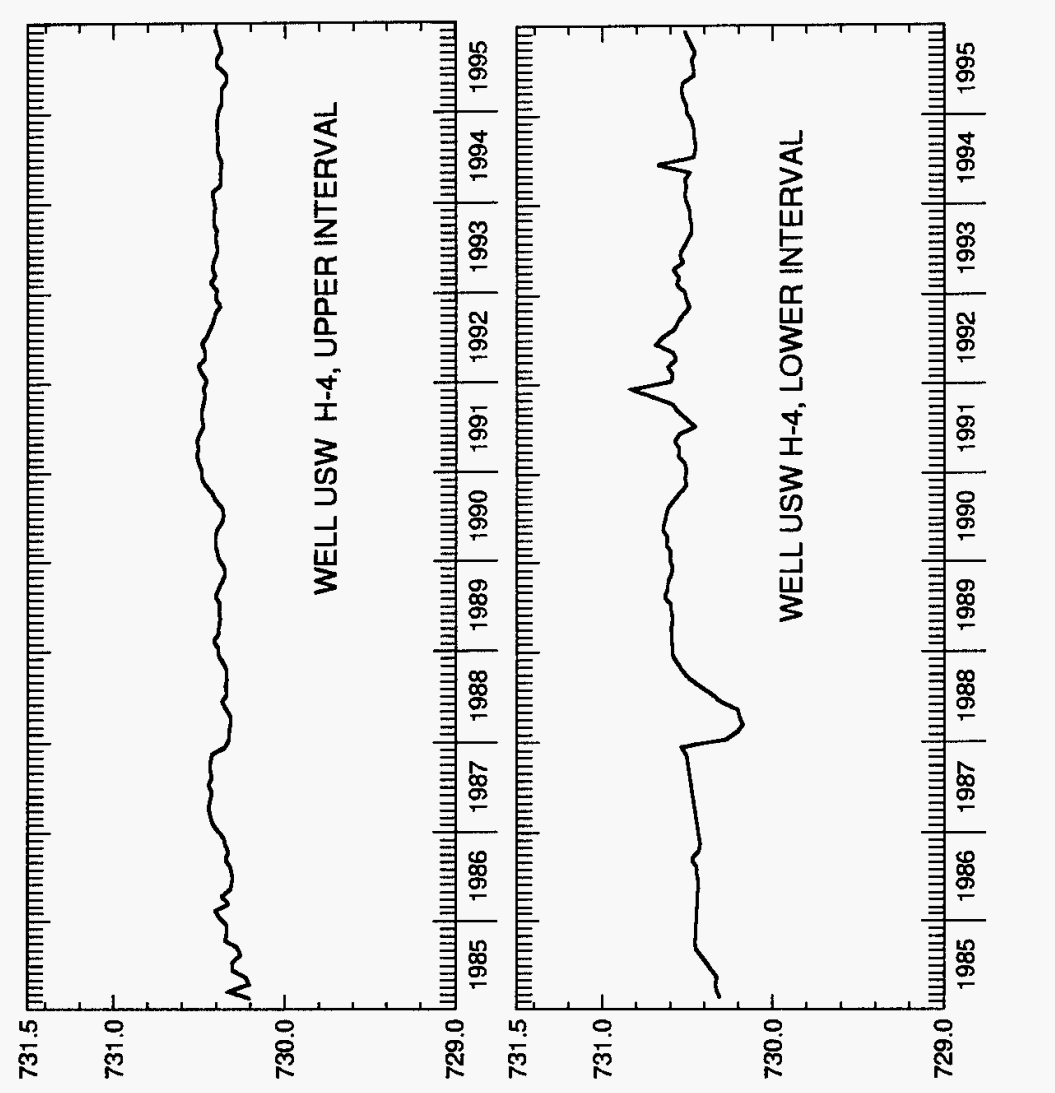

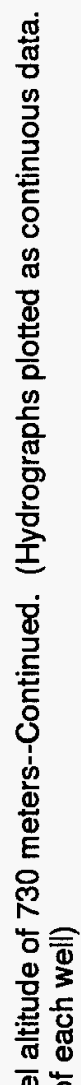

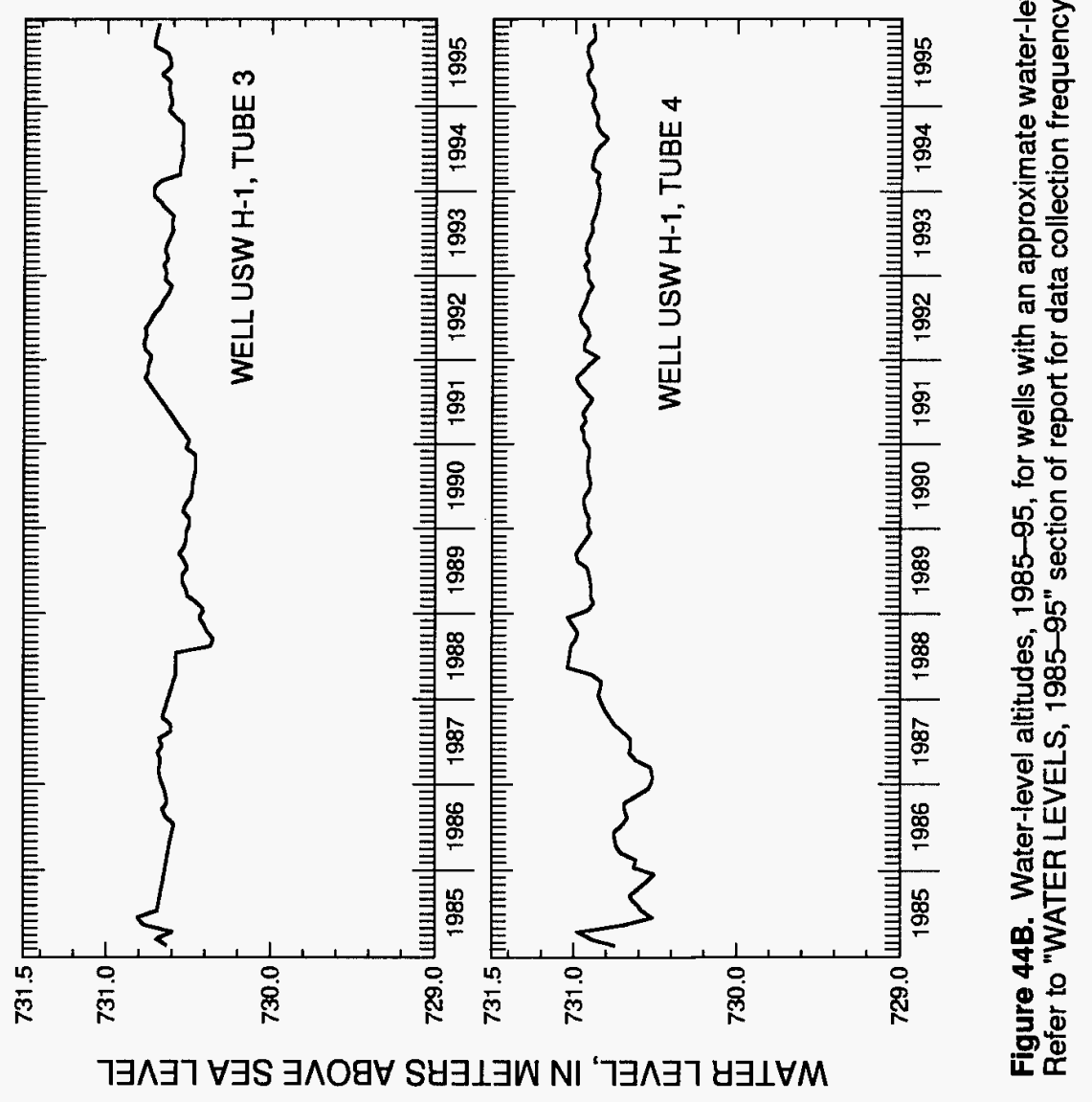




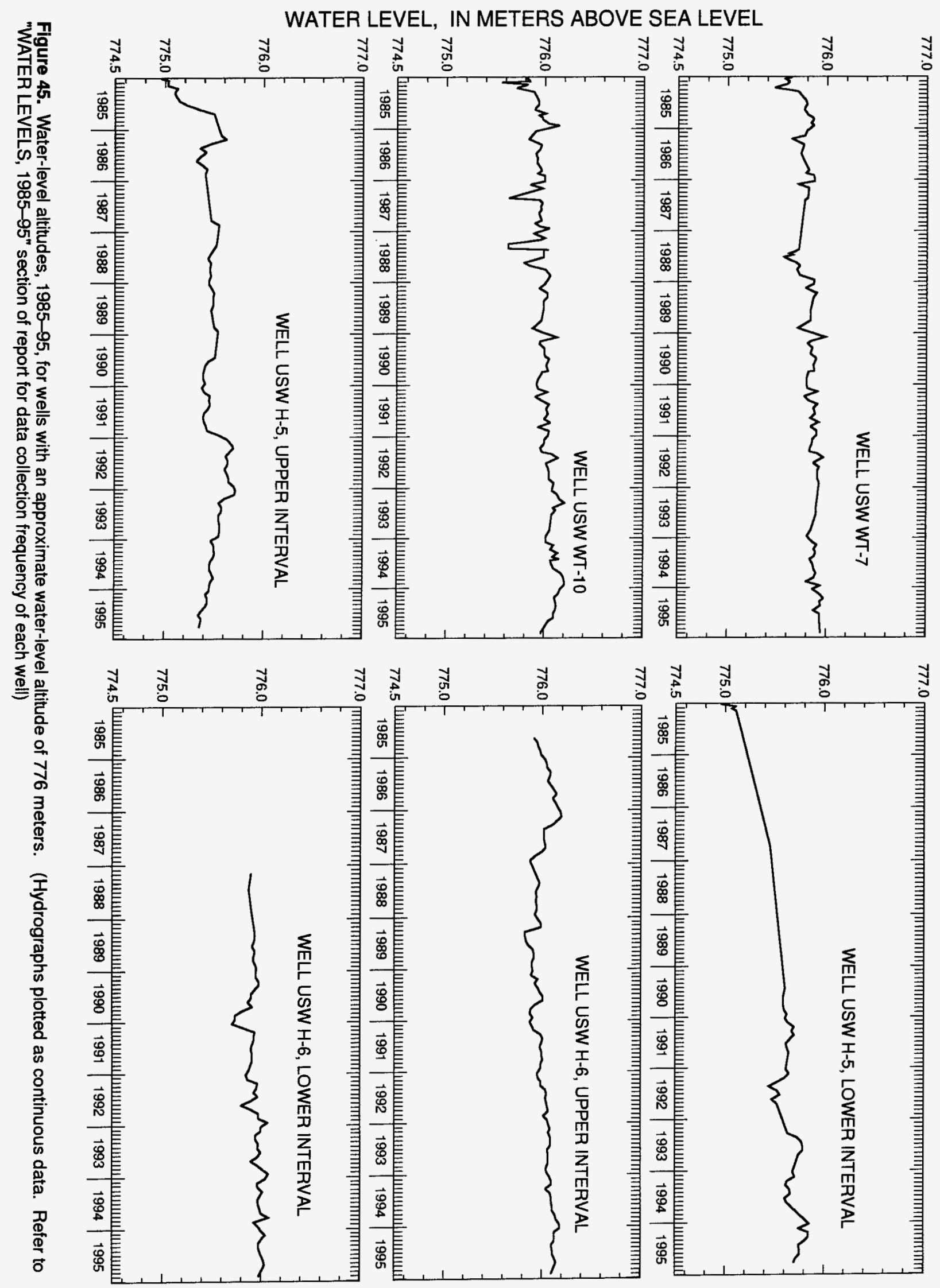




\section{SUMMARY}

From 1985-95, a water-level network that consists of 28 wells for monitoring 36 depth intervals has been maintained in the Yucca Mountain area. The network includes wells that were measured manually, approximately monthly, and/or measured hourly with a transducer/data logger system. Manual water-level measurements were made with either calibrated steel tapes or single or multiconductor-cable units. All wells monitor water levels in Tertiary volcanic rocks, except one that monitors water levels in Paleozoic carbonate rocks.

Mean annual water-level altitudes for all wells for the period 1985-95 ranged from 727.93 to $1,034.60 \mathrm{~m}$. The maximum range in water-level change between monthly measurements and/or monthly mean values was $12.22 \mathrm{~m}$ in well USW H-3, lower interval, and the minimum range was $0.31 \mathrm{~m}$ in wells UE-25 b\#1, upper interval, and J-11. In 31 of the 36 depth intervals monitored, the range of water-level change was less than $1 \mathrm{~m}$. The range of standard deviation of all depth intervals for all wells that were monitored was 0.053 to $3.098 \mathrm{~m}$.

No seasonal water-level trends were detected in any of the wells, and regional ground-water withdrawals did not appear to cause water-level changes. Most annual water-level fluctuations can be attributed to barometric and Earth-tide changes. Regional earthquakes, which occurred on June 28-29, 1992, might have simultaneously affected the water level in seven wells (UE-25 WT\#4, UE-25 WT\#6, USW WT-11, UE-25 WT\#12, UE-25 WT\#16, UE-25 b\#1, upper interval, and UE-25 p\#1); however, the direction of water-level change (water-level rises or declines) was not uniform.

The only consistent water-level changes observed between any two wells were between wells USW WT-7 and USW WT-10, and between USW VH-1 and USW WT-7. Wells USW WT- 7 and USW WT-10 had similar water-level patterns from February 1989 through July 1992. Slight similarities were observed between wells USW VH-1 and USW WT-7 from September 1986 through February 1987, and from June 1993 through January 1994; however, these similarities were not as continuous or striking as those observed between USW WT-7 and USW WT-10.

Periods of rising and declining water levels were observed in most wells. However, 11 years of record was not sufficient to determine if these periods were cyclic. Because a goal of monitoring water levels at Yucca Mountain is to determine if there are water-level trends that could affect the potential repository, observed water-level changes over the period of this report may not be representative of the overall long-term trends in water levels. Subsequently, continuous long-term ground-water-level data need to be collected to determine conclusively if cyclic trends do exist.

\section{REFERENCES}

Bentley, C.B., Robison, J.H., and Spengler, R.W., 1983, Geohydrologic data for test well USW H-5, Yucca Mountain area, Nye County, Nevada: U.S. Geological Survey Open-File Report 83-853, 34 p.

Boucher, M.S., 1994, Water levels in wells J-11 and J-12, 1989-91, Yucca Mountain area, Nevada: U.S. Geological Survey Open-File Report 94-303, 9 p.

Byers, F.M., Jr., Carr, W.J., Orkild, P.P., Quinlivan, W.D., and Sargent, K.A., 1976, Volcanic suites and related cauldrons of Timber Mountain-Oasis Valley caldera complex, southem Nevada: U.S. Geological Survey Professional Paper 919, $70 \mathrm{p}$.

Carr, W.J., 1988, Volcano-tectonic setting of Yucca Mountain and Crater Flat, southwestern Nevada, in Carr, M.D., and Yount, J.C., eds., Geologic and hydrologic investigations of a potential nuclear waste disposal site at Yucca Mountain, southern Nevada: U.S. Geological Survey Bulletin 1790, p. 35-49.

Carr, W.J., Byers, F.M., Jr., and Orkild, P.P., 1986, Stratigraphic and volcano-tectonic relations of Crater Flat Tuff and some older volcanic units, Nye County, Nevada: U.S. Geological Survey Professional Paper 1323, 28 p.

Craig, R.W., and Johnson, K.A., 1984, Geohydrologic data for test well UE-25 p\#1, Yucca Mountain area, Nye County, Nevada: U.S. Geological Survey Open-File Report 84-450, 63 p.

Craig, R.W., Reed, R.L., and Spengler, R.W., 1983, Geohydrologic data for test well USW H-6, Yucca Mountain area, Nye County, Nevada: U.S. Geological Survey Open-File Report 83-856, 35 p. 
Craig, R.W., and Robison, J.H., 1984, Geohydrology of test well UE-25 p\#1, Yucca Mountain area, Nye County, Nevada: U.S. Geological Survey Water-Resources Investigations Report 84-4248, $57 \mathrm{p}$.

Erickson, J.R., and Waddell, R.K., 1985, Identification and characterization of hydrologic properties of fractured tuff using hydraulic and tracer tests-Test well USW H-4, Yucca Mountain, Nye County, Nevada: U.S. Geological Survey WaterResources Investigations Report 85-4066, 30 p.

Ervin, E.M., Luckey, R.R., and Burkhardt, D.J., 1994, Revised potentiometric-surface map, Yucca Mountain and vicinity, Nevada: U.S. Geological Survey Water-Resources Investigations Report 93-4000, 17 p.

Fenix \& Scisson, Inc., 1986a, NNWSI hole histories-_UE-25 WT\#3, UE-25 WT\#4, UE-25 WT\#5, UE-25 WT\#6, UE-25 WT\#12, UE-25 WT\#13, UE-25 WT\#14, UE-25 WT\#15, UE-25 WT\#16, UE-25 WT\#17, UE-25 WT\#18, USW WT-1, USW WT-2, USW WT-7, USW WT-10, USW WT-11: U.S. Department of Energy DOE/NV/10322-10, 111 p. 1986b, NNWSI hole history -UE-25 b\#1: U.S. Department of Energy DOE/NV/10322-13, $37 \mathrm{p}$. 1986c, NNWSI hole history-UE-25 p\#1: U.S. Department of Energy DOE/NV/10322-16, 39 p. 1987a, NNWSI hole histories_-USW H-1, USW H-3, USW H-4, USW H-5, USW H-6: U.S. Department of Energy DOE/NV/10322-18, $99 \mathrm{p}$. 1987b, NNWSI hole histories - USW G-1, USW G-2, USW G-3, USW G-4, USW GA-1, USW GU-3: U.S. Department of Energy DOE/NV/10322-19, $187 \mathrm{p}$. 1987c, NNWSI drilling and mining summary: U.S. Department of Energy DOE/NV/10322-24, 45 p.

Gemmell, J.M., 1990, Water levels in periodically measured wells in the Yucca Mountain area, Nevada, 1988: U.S. Geological Survey Open-File Report 90-113, 47 p.

Graves R.P., Tucci, Patrick, and Goemaat, R.L., 1996, Water levels in the Yucca Mountain area, Nevada, 1994: U.S. Geological Survey Open-File Report 95-757, 101 p.

Lahoud, R.G., Lobmeyer, D.H., and Whitfield, M.S., Jr., 1984, Geohydrology of volcanic tuff penetrated by test well UE-25 b \#1, Yucca Mountain, Nye County, Nevada: U.S. Geological Survey Water-Resources Investigations Report $84-4253,44 \mathrm{p}$.

Lehman, Linda, Rice, Jay, and Keen, Kerry, 1990, Cosine components in water levels, Yucca Mountain, Nevada: Burnsville, Minn., L. Lehman and Associates, 15 p.

Lobmeyer, D.H., Luckey, R.R., O'Brien, G.M., and Burkhardt, D.J., 1995, Water levels in continuously monitored wells in the Yucca Mountain area, Nevada, 1989: U.S. Geological Survey Open-File Report 93-098, 173 p.

Lobmeyer, D.H., Whitfield, M.S., Jr., Lahoud, R.G., and Bruckheimer, Laura, 1983, Geohydrologic data for test well UE-25 b \#1, Nevada Test Site, Nye County, Nevada: U.S. Geological Survey Open-File Report 83-855, 48 p.

Luckey, R.R., Lobmeyer, D.H., and Burkhardt, Douglas, 1993, Water levels in continuously monitored wells in the Yucca Mountain area, Nevada, 1985-88: U.S. Geological Survey Open-File Report 91-493, 252 p.

Maldonado, Florian, and Koether, S.L., 1983, Stratigraphy, structure, and some petrographic features of Tertiary volcanic rocks at the USW G-2 drill hole, Yucca Mountain, Nye County, Nevada: U.S. Geological Survey Open-File Report $83-732,83 \mathrm{p}$.

Matuska, N.A., 1988, Ground-water sampling of NNWSI water table test wells surrounding Yucca Mountain, Nevada: Desert Research Institute, Water Resources Center, report no. NWPO-TR-010-89, 20 p.

Muller, D.C., and Kibler, J.E., 1985, Preliminary analysis of geophysical logs from WT series drill holes, Yucca Mountain, Nye County, Nevada: U.S. Geological Survey Open-File Report 86-46, 29 p.

Nelson, P.H., and Schimschal, Ulrich, 1993, Assessment of geophysical logs from borehole USW G-2, Yucca Mountain, Nevada: U.S. Geological Survey Open-File Report 92-572, 34 p.

O'Brien, G.M., 1991, Water levels in periodically measured wells in the Yucca Mountain area, Nevada, 1989: U.S. Geological Survey Open-File Report 91-178, 51 p. 1993, Earthquake-induced water-level fluctuations at Yucca Mountain, Nevada, June 1992: U.S. Geological Survey Open-File Report 93-73, 12 p.

1994, Equipment and procedures for monitoring deep water levels at Yucca Mountain, Nevada, in Hollett and others, comps., Proceedings of a U.S. Geological Survey workshop on the application and needs of submersible pressure sensors, Denver, Colo., June 7-10, 1994: U.S. Geological Survey Open-File Report 94-531, 53 p.

O'Brien, G.M., Tucci, Patrick, and Burkhardt, D.J., 1995, Water levels in the Yucca Mountain area, Nevada, 1992: U.S. Geological Survey Open-File Report 94-311, 74 p.

Robison, J.H., 1984, Ground-water level data and preliminary potentiometric surface maps, Yucca Mountain and vicinity, Nye County, Nevada: U.S. Geological Survey Water-Resources Investigations Report 84-4197, 8 p.

Robison, J.H., Stephens, D.M., Luckey, R.R., and Baldwin, D.A., 1988, Water levels in periodically measured wells in the Yucca Mountain area, Nevada, 1981-87: U.S. Geological Survey Open-File Report 88-468, 132 p. 
Rush, F.E., Thordarson, William, and Bruckheimer, Laura, 1983, Geohydrologic and drillhole data for test well USW H-1, adjacent to Nevada Test Site, Nye County, Nevada: U.S. Geological Survey Open-File Report 83-141, 38 p.

Rush, F.E., Thordarson, William, and Pyles, D.G., 1984, Geohydrology of test well USW H-1, Yucca Mountain, Nye County, Nevada: U.S. Geological Survey Water-Resources Investigations Report 84-4032, 56 p.

Sawyer, D.A., Fleck, R.J., Lanphere, M.A., Warren, R.G., Broxton, M.R., 1994, Episodic caldera volcanism in the Miocene southwestern Nevada volcanic field-Revised stratigraphic framework, ${ }^{40} \mathrm{Ar} /{ }^{39} \mathrm{Ar}$ geochronology, and implications for magmatism and extension: Geological Society of America Bulletin, v. 106, p. 1304-1418.

Thordarson, William, 1983, Geohydrologic data and test results from well J-13, Nevada Test Site, Nye County, Nevada: U.S. Geological Survey Water-Resources Investigations Report 83-4171, 57 p.

Thordarson, William, and Howells, Lewis, 1987, Hydraulic tests and chemical quality of water at well USW VH-1, Crater Flat, Nye County, Nevada: U.S. Geological Survey Water-Resources Investigations Report 86-4359, 20 p.

Thordarson, William, Rush, F.E., Spengler, R.W., and Waddell, S.J., 1984, Geohydrologic and drillhole data for test well USW H-3, Yucca Mountain, Nye County, Nevada: U.S. Geological Survey Open-File Report 84-149, 54 p.

Thordarson, William, Rush, F.E., and Waddell, S.J., 1984, Geohydrology of test well USW H-3, Yucca Mountain, Nye County, Nevada: U.S. Geological Survey Water-Resources Investigations Report 84-4272, 38 p.

Tucci, Patrick, O’Brien, G.M., and Burkhardt, D.J., 1996, Water levels in the Yucca Mountain area, Nevada, 1990-91: U.S. Geological Survey Open-File Report 94-111, 107 p.

Tucci, Patrick, Goemaat R.L., and Burkhardt, D.J., in 1996, Water levels in the Yucca Mountain area, Nevada, 1993: U.S. Geological Survey Open-File Report 95-159, 94 p.

Tucci, Patrick, and Burkhardt, D.J., 1995, Potentiometric-surface map, 1993, Yucca Mountain and vicinity, Nevada: Water-Resources Investigations Report 95-4149, 15 p.

U.S. Department of Energy, 1988, Site characterization plan, Yucca Mountain site, Nevada research and development area, Nevada: U.S. Department of Energy Report DOE RW/0199, v. 8, variously paged.

Whitfield, M.S., Jr., Eshom, E.P., Thordarson, William, and Schaefer, D.H., 1985, Geohydrology of rocks penetrated by test well USW H-4, Yucca Mountain, Nye County, Nevada: U.S. Geological Survey Water-Resources Investigations Report $85-4030,33 \mathrm{p}$.

Whitfield, M.S., Jr., Thordarson, William, and Eshom, E.P., 1984, Geohydrologic and drillhole data for test well USW H-4, Yucca Mountain, Nye County, Nevada: U.S. Geological Survey Open-File Report 84 449, 39 p.

Winograd, I.J., and Thordarson, William, 1975, Hydrogeologic and hydrochemical framework, south-central Great Basin, Nevada-California, with special reference to the Nevada Test Site: U.S. Geological Survey Professional Paper 712-C, $126 \mathrm{p}$.

Young, R.A., 1972, Water supply for the Nuclear Rocket Development Station at the U.S. Atomic Energy Commission's Nevada Test Site: U.S. Geological Survey Water-Supply Paper 1938, 19 p. 


\section{APPENDIX A}

This section contains information for all wells discussed in this report. Information for each well includes location and identification, drilling and casing information, access to and description of interval for measuring water level, and information for calculation of water-level altitude. Source of information for each well is mostly from published information. These sources are referenced in the discussion of each well. The complete bibliographic citations for all sources are in the "References" section of this report. Borehole-geophysical logs and core-measurement data for the wells are given by Nelson and others (1991). Although water-level altitudes are corrected for borehole deviation, other depth-related values (such as casing or access-tube depths) in this section are uncorrected for borehole deviation. 


\section{Well USW WT-1}

Information about the history of well USW WT-1 and about previous data from the well was obtained from various sources. These sources are: Robison (1984); Robison (U.S. Geological Survey, written commun., 1986); Robison and others (1988); Holmes \& Narver, Inc. (written commun., 1986); and Fenix \& Scisson, Inc. (1986a, 1987c).

Well specifications

1. Location and identification:

Latitude and longitude: $36^{\circ} 49^{\prime} 16^{\prime \prime} \mathrm{N}$; $116^{\circ} 26^{\prime} 56^{\prime \prime} \mathrm{W}$.

Nevada State Central Zone Coordinates (m): N 229,801; E 171,828.

U.S. Geological Survey Site ID: 364916116265601.

2. Drilling and casing information:

Well started: April 28, 1983.

Well completed: May 18, 1983.

Drilling method: Rotary, using rock bits and air, water, and soap-circulating medium; core obtained from bottom of the borehole.

Bit diameter below water level: $222 \mathrm{~mm}$.

Casing: Surface casing only, to a depth of $9.91 \mathrm{~m}$.

Total drilled depth: $515 \mathrm{~m}$.

3. Access to and description of depth interval for measuring water levels:

62-mm inside-diameter tubing that has a 3.7-m-long well screen on the bottom; tubing and attached screen extend from land surface to a depth of $507.5 \mathrm{~m}$; saturated interval of the borehole is within the Calico Hills Formation and Bullfrog Tuff of the Crater Flat Group.

4. Information for calculating water-level altitude:

Reference point: Top of metal tag on well casing, altitude 1,201.11 m (surveyed by U.S. Geological Survey, 1984).

Measuring point: Top of access tube, $0.314 \mathrm{~m}$ above reference point.

Depth correction for borehole deviation from vertical: $0.326 \mathrm{~m}$, based on approximate depth to water of $471 \mathrm{~m}$ (1990 data). 


\section{Well USW WT-2}

Information about the history of well USW WT-2 and about previous data from the well was obtained from various sources. These sources are: Robison (1984); Robison (U.S. Geological Survey, written commun., 1986); Robison and others (1988); and Fenix \& Scisson, Inc. (1986a, 1987c).

Well specifications

1. Location and identification:

Latitude and longitude: $36^{\circ} 50^{\prime} 23^{\prime \prime} \mathrm{N}$.; $116^{\circ} 27^{\prime} 18^{\prime \prime} \mathrm{W}$.

Nevada State Central Zone Coordinates (m): N 231,849; E 171,274.

U.S. Geological Survey Site ID: 365023116271801.

2. Drilling and casing information:

Well started: July 8, 1983.

Well completed: July 16, 1983.

Drilling method: Rotary, using rock bits and air-foam circulating medium; core obtained from bottom of the borehole.

Bit diameter below water level: $222 \mathrm{~mm}$.

Casing: Surface casing only, to a depth of $18 \mathrm{~m}$.

Total drilled depth: $628 \mathrm{~m}$.

3. Access to and description of depth interval for measuring water levels:

62-mm inside-diameter access tubing that has a 3.6-m-long well screen on bottom, extending from land surface to a depth of $622 \mathrm{~m}$; saturated interval of the borehole is within the Prow Pass Tuff of the Crater Flat Group.

4. Information for calculating water-level altitude:

Reference point: Top of metal tag on well casing; altitude $1,301.13 \mathrm{~m}$ (surveyed by U.S. Geological Survey, 1984).

Measuring point: Top of access tube, $0.305 \mathrm{~m}$ after 12/08/93, $0.146 \mathrm{~m}$ between 9/09/93 and $12 / 08 / 93,0.311 \mathrm{~m}$ prior to $9 / 09 / 93$ (all measuring points are above reference point).

Depth correction for borehole deviation from vertical: $0.445 \mathrm{~m}$ after $12 / 08 / 93$ and $0.533 \mathrm{~m}$ prior to $12 / 08 / 93$, based on approximate depth to water of $571 \mathrm{~m}$. 


\section{Well UE-25 WT\#3}

Information about the history of well UE-25 WT\#3 and about previous data from the well was obtained from various sources. These sources are: Robison (1984); Robison (U.S. Geological Survey, written commun., 1986); Robison and others (1988); and Fenix \& Scisson, Inc. (1986a, 1987c).

Well specifications

1. Location and identification:

Latitude and longitude: $36^{\circ} 47^{\prime} 57^{\prime \prime} \mathrm{N} . ; 116^{\circ} 24^{\prime} 58^{\prime \prime} \mathrm{W}$.

Nevada State Central Zone Coordinates (m): N 227,379; E 174,768.

U.S. Geological Survey Site ID: 364757116245801.

2. Drilling and casing information:

Well started: April 29, 1983.

Well completed: May 25, 1983.

Drilling method: Rotary, using rock bits and air-foam circulating medium; core obtained from bottom of the borehole.

Bit diameter below water level: $222 \mathrm{~mm}$.

Casing: Surface casing only, to a depth of $12 \mathrm{~m}$.

Total drilled depth: $348 \mathrm{~m}$.

3. Access to and description of depth interval for measuring water levels:

62-mm inside-diameter tubing that has a 3.6-m-long well screen on bottom, extending from land surface to a depth of $343 \mathrm{~m}$; saturated interval of the borehole is within the Bullfrog Tuff of the Crater Flat Group.

4. Information for calculating water-level altitude:

Reference point: Top of metal tag on well casing; altitude 1,030.11 m (surveyed by U.S. Geological Survey, 1984).

Measuring point: Top of access tubing, $0.155 \mathrm{~m}$ above reference point.

Depth correction for borehole deviation from vertical: $0.271 \mathrm{~m}$, based on approximate depth to water of $300 \mathrm{~m}$ (1990 data). 


\section{Well UE-25 WT\#4}

Information about the history of well UE-25 WT\#4 and about previous data from the well was obtained from various sources. These sources are: Robison (1984); Robison (U.S. Geological Survey, written commun., 1986); Robison and others (1988); Holmes \& Narver, Inc. (written commun., 1986); and Fenix \& Scisson, Inc. (1986a, 1987c).

Well specifications

1. Location and identification:

Latitude and longitude: $36^{\circ} 51^{\prime} 40^{\prime \prime} \mathrm{N}$.; $116^{\circ} 26^{\prime} 03^{\prime \prime} \mathrm{W}$.

Nevada State Central Zone Coordinates (m): N 234,242; E 173,139.

U.S. Geological Survey Site ID: 365140116260301.

2. Drilling and casing information:

Well started: May 28, 1983.

Well completed: June 6, 1983.

Drilling method: Rotary, using rock bits and air-foam circulating medium;

Core obtained from bottom of the borehole.

Bit diameter below water level: $222 \mathrm{~mm}$.

Casing: Surface casing only, to a depth of $14.6 \mathrm{~m}$.

Total drilled depth: $482 \mathrm{~m}$.

3. Access to and description of depth interval for measuring water levels:

62-mm inside-diameter tubing that has a 3.7-m-long well screen on the bottom; tubing and attached screen extend from land surface to a depth of $477.6 \mathrm{~m}$; saturated interval of the borehole is within the Calico Hills Formation.

4. Information for calculating water-level altitude:

Reference point: Top of metal tag on well casing, altitude 1,169.21 m (surveyed by U.S. Geological Survey, 1984).

Measuring point: Top of access tube, $0.311 \mathrm{~m}$ above reference point.

Depth correction for borehole deviation from vertical: $0.454 \mathrm{~m}$, based on approximate depth to water of $438 \mathrm{~m}$ (1990 data). 


\section{Well UE-25 WT\#6}

Information about the history of well UE-25 WT\#6 and about previous data from the well was obtained from various sources. These sources are: Robison (1984); Robison (U.S. Geological Survey, written commun., 1986); Robison and others (1988); and Fenix \& Scisson, Inc. (1986a, 1987c).

\section{Well specifications}

1. Location and identification:

Latitude and longitude: $36^{\circ} 53^{\prime} 40^{\prime \prime} \mathrm{N}$.; $116^{\circ} 26^{\prime} 46^{\prime \prime} \mathrm{W}$.

Nevada State Central Zone Coordinates (m): N 237,920; E 172,067.

U.S. Geological Survey Site ID: 365340116264601.

2. Drilling and casing information:

Well started: June 20, 1983.

Well completed: June 29, 1983.

Drilling method: Rotary, using rock bits and air-foam circulating medium; core obtained from bottom of the borehole.

Bit diameter below water level: $171 \mathrm{~mm}$.

Casing: Surface casing only, to a depth of $76.5 \mathrm{~m}$.

Total drilled depth: $383 \mathrm{~m}$.

3. Access to and description of depth interval for measuring water levels:

62-mm inside-diameter tubing that has a 3.6-m-long well screen on bottom, extending from land surface to a depth of $372 \mathrm{~m}$; saturated interval of the borehole is within the Calico Hills Formation.

4. Information for calculating water-level altitude:

Reference point: Top of metal tag on well casing; altitude 1,314.78 m (surveyed by U.S. Geological Survey, 1984).

Measuring point: Top of access tube, $0.463 \mathrm{~m}$ above reference point.

Depth correction for borehole deviation from vertical: $0.204 \mathrm{~m}$, based on approximate depth to water of $280 \mathrm{~m}$ (1990 data). 


\section{Well USW WT-7}

Information about the history or well USW WT-7 and about previous data from the well was obtained from various sources. These sources are: Robison (1984); Robison (U.S. Geological Survey, written commun., 1986); Robison and others (1988); Holmes \& Narver, Inc. (written commun., 1986); and Fenix \& Scisson, Inc. (1986a, 1987c).

Well specifications

1. Location and identification:

Latitude and longitude: $36^{\circ} 49^{\prime} 33^{\prime \prime} \mathrm{N} . ; 116^{\circ} 28^{\prime} 57^{\prime \prime} \mathrm{W}$.

Nevada State Central Zone Coordinates (m): N 230,298; E 168,826.

U.S. Geological Survey Site ID: 364933116285701.

2. Drilling and casing information:

Well started: July 19, 1983.

Well completed: July 26, 1983.

Drilling method: Rotary, using rock bits and air-foam circulating medium; core obtained from bottom of the borehole.

Bit diameter below water level: $222 \mathrm{~mm}$.

Casing: Surface casing only, to a depth of $15.8 \mathrm{~m}$.

Total drilled depth: $491 \mathrm{~m}$.

3. Access to and description of depth interval for measuring water levels:

62-mm inside-diameter tubing that has a 3.7-m-long well screen on the bottom; tubing and attached screen extend from land surface to a depth of $481.3 \mathrm{~m}$; saturated interval of the borehole is within the Topopah Spring Tuff of the Paintbrush Group and the Prow Pass Tuff of the Crater Flat Group.

4. Information for calculating water-level altitude:

Reference point: Top of metal tag on well casing, altitude 1,196.88 m (surveyed by U.S. Geological Survey, 1984).

Measuring point: Top of access tube, $0.302 \mathrm{~m}$ above reference point.

Depth correction for borehole deviation from vertical: $0.034 \mathrm{~m}$, based on approximate depth to water of $421 \mathrm{~m}$ (1990 data). 


\section{Well USW WT-10}

Information about the history of well USW WT-10 and about previous data from the well was obtained from various sources. These sources are: Robison (1984); Robison (U.S. Geological Survey, written commun., 1986); Robison and others (1988); Holmes \& Narver, Inc. (written commun., 1986); and Fenix \& Scisson, Inc. (1986a, 1987c).

\section{Well specifications}

1. Location and identification:

Latitude and longitude: $36^{\circ} 48^{\prime} 25^{\prime \prime} \mathrm{N}$.; $116^{\circ} 29^{\prime} 05^{\prime \prime} \mathrm{W}$.

Nevada State Central Zone Coordinates (m): N 228,225; E 168,646.

U.S. Geological Survey Site ID: 364825116290501.

2. Drilling and casing information:

Well started: July 26, 1983.

Well completed: August 2, 1983.

Drilling method: Rotary, using rock bits and air-foam circulating medium; core obtained from bottom of the borehole.

Bit diameter below water level: $222 \mathrm{~mm}$.

Casing: Surface casing only, to a depth of $34.7 \mathrm{~m}$.

Total drilled depth: $431 \mathrm{~m}$.

3. Access to and description of depth interval for measuring water levels:

62-mm inside-diameter tubing that has a 3.7- $\mathrm{m}$-long well screen on the bottom; tubing and attached screen extend from land surface to a depth of $402.6 \mathrm{~m}$; saturated interval of the borehole is within the Topopah Spring Tuff of the Paintbrush Group.

4. Information for calculating water-level altitude:

Reference point: Top of metal tag on well casing, altitude $1,123.40 \mathrm{~m}$ (surveyed by U.S. Geological Survey, 1984).

Measuring point: Top of access tube, $0.314 \mathrm{~m}$ above reference point.

Depth correction for borehole deviation from vertical: $0.030 \mathrm{~m}$, based on approximate depth to water of $347 \mathrm{~m}$ (1990 data). 


\section{Well USW WT-11}

Information about the history of well USW WT-11 and about previous data from the well was obtained from various sources. These sources are: Robison (1984); Robison (U.S. Geological Survey, written commun., 1986); Robison and others (1988); and Fenix \& Scisson, Inc. (1986a, 1987c).

\section{Well specifications}

1. Location and identification:

Latitude and longitude: $36^{\circ} 46^{\prime} 49^{\prime \prime} \mathrm{N}$.; $116^{\circ} 28^{\prime} 02^{\prime \prime} \mathrm{W}$.

Nevada State Central Zone Coordinates (m): N 225,269; E 170,193.

U.S. Geological Survey Site ID: 364649116280201.

2. Drilling and casing information:

Well started: August 3, 1983.

Well completed: August 9, 1983.

Drilling method: Rotary, using rock bits and air-foam circulating medium; core obtained from bottom of the borehole.

Bit diameter below water level: $222 \mathrm{~mm}$.

Casing: Surface casing only, to a depth of $14 \mathrm{~m}$.

Total drilled depth: $441 \mathrm{~m}$.

3. Access to and description of depth interval for measuring water levels:

62-mm inside-diameter tubing that has a 3.6-m-long well screen on bottom, extending from land surface to a depth of $416 \mathrm{~m}$; saturated interval of the borehole is within the Topopah Spring Tuff of the Paintbrush Group and the Calico Hills Formation.

4. Information for calculating water-level altitude:

Reference point: Top of metal tag on well casing; altitude 1,094.11 m (surveyed by U.S. Geological Survey, 1984).

Measuring point: Top of access tube, $0.311 \mathrm{~m}$ above reference point.

Depth correction for borehole deviation from vertical: $0.116 \mathrm{~m}$, based on approximate depth to water of $363 \mathrm{~m}$ (1990 data). 


\section{Well UE-25 WT\#12}

Information about the history of well UE-25 WT\#12 and about previous data from the well was obtained from various sources. These sources are: Robison (1984); Robison (U.S. Geological Survey, written commun., 1986); Robison and others (1988); Holmes \& Narver, Inc. (written commun., 1986); and Fenix \& Scisson, Inc. (1986a, 1987c).

Well specifications

1. Location and identification:

Latitude and longitude: $36^{\circ} 46^{\prime} 56^{\prime \prime} \mathrm{N}$.; $116^{\circ} 26^{\prime} 16^{\prime \prime} \mathrm{W}$.

Nevada State Central Zone Coordinates (m): N 225,468; E 172,825.

U.S. Geological Survey Site ID: 364656116261601.

2. Drilling and casing information:

Well started: August 11, 1983.

Well completed: August 16, 1983.

Drilling method: Rotary, using rock bits and air-foam circulating medium; core obtained from bottom of the borehole.

Bit diameter below water level: $222 \mathrm{~mm}$.

Casing: Surface casing only, to a depth of $21.3 \mathrm{~m}$.

Total drilled depth: $399 \mathrm{~m}$.

3. Access to and description of depth interval for measuring water levels:

62-mm inside-diameter tubing that has a 3.7-m-long well screen on the bottom; tubing and attached screen extend from land surface to a depth of $388.9 \mathrm{~m}$; saturated interval of the borehole is within the Topopah Spring Tuff of the Paintbrush Group and the Calico Hills Formation.

4. Information for calculating water-level altitude:

Reference point: Top of metal tag on well casing, altitude 1,074.74 m (surveyed by U.S. Geological Survey, 1984).

Measuring point: Top of access tube, $0.305 \mathrm{~m}$ above reference point.

Depth correction for borehole deviation from vertical: $0.183 \mathrm{~m}$, based on approximate depth to water of $345 \mathrm{~m}$ (1990 data). 


\section{Well UE-25 WT\#13}

Information about the history of well UE-25 WT\#13 and about previous data from the well was obtained from various sources. These sources are: Robison (1984); Robison (U.S. Geological Survey, written commun., 1986); Robison and others (1988); and Fenix \& Scisson, Inc. (1986a, 1987c).

\section{Well specifications}

1. Location and identification:

Latitude and longitude: $36^{\circ} 49^{\prime} 43^{\prime \prime} \mathrm{N}$.; $116^{\circ} 23^{\prime} 51^{\prime \prime} \mathrm{W}$.

Nevada State Central Zone Coordinates (m): N 230,647; E 176,405.

U.S. Geological Survey Site ID: 364945116235001.

2. Drilling and casing information:

Well started: June 29, 1983.

Well completed: July 7, 1983.

Drilling method: Rotary, using rock bits and air-foam circulating medium; core obtained from bottom of the borehole.

Bit diameter below water level: $222 \mathrm{~mm}$.

Casing: Surface casing only, to a depth of $68 \mathrm{~m}$.

Total drilled depth: $354 \mathrm{~m}$.

3. Access to and description of depth interval for measuring water levels:

62-mm inside-diameter tubing that has a 3.6-m-long well screen on bottom, extending from land surface to a depth of $346 \mathrm{~m}$; saturated interval of the borehole is within the Topopah Spring Tuff of the Paintbrush Group.

4. Information for calculating water-level altitude:

Reference point: Top of metal tag on well casing; altitude 1,032.51 m (surveyed by U.S. Geological Survey, 1984).

Measuring point: Top of access tube, $0.305 \mathrm{~m}$ above reference point.

Depth correction for borehole deviation from vertical: $0.012 \mathrm{~m}$, based on approximate depth to water of $304 \mathrm{~m}$ (1990 data). 


\section{Well UE-25 WT\#14}

Information about the history of well UE-25 WT\#14 and about previous data from the well was obtained from various sources. These sources are: Robison (1984); Robison (U.S. Geological Survey, written commun., 1986); Robison and others (1988); Holmes \& Narver, Inc., (written commun., 1986); and Fenix \& Scisson, Inc. (1986a, 1987c).

Well specifications

1. Location and identification:

Latitude and longitude: $36^{\circ} 50^{\prime} 32^{\prime \prime} \mathrm{N}$.; $116^{\circ} 24^{\prime} 35^{\prime \prime} \mathrm{W}$.

Nevada State Central Zone Coordinates (m): N 232,151; E 175,324.

U.S. Geological Survey Site ID: 365032116243501.

2. Drilling and casing information:

Well started: August 17, 1983.

Well completed: September 30, 1983.

Drilling method: Rotary, using rock bits and air-foam circulating medium; core obtained from bottom of the borehole.

Bit diameter below water level: $222 \mathrm{~mm}$.

Casing: Surface casing only, to a depth of $36.6 \mathrm{~m}$.

Total drilled depth: $399 \mathrm{~m}$.

3. Access to and description of depth interval for measuring water levels:

62-mm inside-diameter tubing that has a 3.7-m-long well screen on the bottom; tubing and attached screen extend from land surface to a depth of $397.2 \mathrm{~m}$; saturated interval of the borehole is within the Topopah Spring Tuff of the Paintbrush Group and the Calico Hills Formation.

4. Information for calculating water-level altitude:

Reference point: Top of metal tag on well casing, altitude 1,076.05 m (surveyed by U.S. Geological Survey, 1984).

Measuring point: Top of access tube, $0.311 \mathrm{~m}$ above reference point.

Depth correction for borehole deviation from vertical: $0.085 \mathrm{~m}$, based on approximate depth to water of $346 \mathrm{~m}$ (1990 data). 


\section{Well UE-25 WT\#15}

Information about the history of well UE-25 WT\#15 and about previous data from the well was obtained from various sources. These sources are: Robison (1984); Robison (U.S. Geological Survey, written commun., 1986); Robison and others (1988); Holmes \& Narver, Inc. (written commun., 1986); and Fenix \& Scisson, Inc. (1986a, 1987c).

Well specifications

1. Location and identification:

Latitude and longitude: $36^{\circ} 51^{\prime} 16^{\prime \prime} \mathrm{N}$.; $116^{\circ} 23^{\prime} 38^{\prime \prime} \mathrm{W}$.

Nevada State Central Zone Coordinates (m): N 233,512; E 176,725.

2. Drilling and casing information:

Well started: November 12, 1983.

Well completed: November 22, 1983.

Drilling method: Rotary, using rock bits and air-foam circulating medium; core obtained from bottom of the borehole.

Bit diameter below water level: $222 \mathrm{~mm}$.

Casing: Surface casing only, to a depth of $38.7 \mathrm{~m}$.

Total drilled depth: $415 \mathrm{~m}$.

3. Access to and description of depth interval for measuring water levels:

62-mm inside-diameter tubing that has a 3.7-m-long well screen on the bottom; tubing and attached screen extend from land surface to a depth of $406.9 \mathrm{~m}$; saturated interval of the borehole is within the Topopah Spring Tuff of the Paintbrush Group.

4. Information for calculating water-level altitude:

Reference point: Top of metal tag on well casing, altitude 1,082.94 m (surveyed by U.S. Geological Survey, 1984).

Measuring point: Top of access tube, $0.314 \mathrm{~m}$ above reference point.

Depth correction for borehole deviation from vertical: $0.189 \mathrm{~m}$, based on approximate depth to water of $354 \mathrm{~m}$ (1990 data). 


\section{Well UE-25 WT\#16}

Information about the history of well UE-25 WT\#16 and about previous data from the well was obtained from various sources. These sources are: Robison (1984); Robison (U.S. Geological Survey, written commun., 1986); Robison and others (1988); and Fenix \& Scisson, Inc. (1986a, 1987c).

Well specifications

1. Location and identification:

Latitude and longitude: $36^{\circ} 52^{\prime} 39^{\prime \prime} \mathrm{N}$.; $116^{\circ} 25^{\prime} 34^{\prime \prime} \mathrm{W}$.

Nevada State Central Zone Coordinates (m): N 236,043; E 173,856.

U.S. Geological Survey Site ID: 365239116253401.

2. Drilling and casing information:

Well started: November 2, 1983.

Well completed: November 10, 1983.

Drilling method: Rotary, using rock bits and air-foam circulating medium; core obtained from bottom of the core hole.

Bit diameter below water level: $222 \mathrm{~mm}$.

Casing: Surface casing only, to a depth of $31 \mathrm{~m}$.

Total drilled depth: $521 \mathrm{~m}$.

3. Access to and description of depth interval for measuring water levels:

62-mm inside-diameter tubing that has a 3.6-m-long well screen on bottom, extending from land surface to a depth of $514 \mathrm{~m}$; saturated interval of borehole is within the Calico Hills Formation.

4. Information for calculating water-level altitude:

Reference point: Top of metal tag on well casing; altitude 1,210.63 m (surveyed by U.S. Geological Survey, 1984).

Measuring point: Top of access tube, $0.314 \mathrm{~m}$ above reference point.

Depth correction for borehole deviation from vertical: $0.064 \mathrm{~m}$, based on approximate depth to water of $473 \mathrm{~m}$ (1990 data). 


\section{Well UE-25 WT\#17}

Information about the history of well UE-25 WT\#17 and about previous data from the well was obtained from various sources. These sources are: Robison (1984); Robison (U.S. Geological Survey, written commun., 1986); Robison and others (1988); Holmes \& Narver, Inc. (written commun., 1986); and Fenix \& Scisson, Inc. (1986a, 1987c).

Well specifications

1. Location and identification:

Latitude and longitude: $36^{\circ} 48^{\prime} 22^{\prime \prime} \mathrm{N}$.; $116^{\circ} 26^{\prime} 26^{\prime \prime} \mathrm{W}$.

Nevada State Central Zone Coordinates (m): N 228,118; E 172,581.

U.S. Geological Survey Site ID: 364822116262601.

2. Drilling and casing information:

Well started: October 20, 1983.

Well completed: October 30, 1983.

Drilling method: Rotary, using rock bits and air-foam circulating medium; attempt to obtain bottom-hole core unsuccessful, core not obtained from bottom of borehole.

Bit diameter below water level: $222 \mathrm{~mm}$.

Casing: Surface casing only, to a depth of $16.8 \mathrm{~m}$.

Total drilled depth: $443 \mathrm{~m}$.

3. Access to and description of depth interval for measuring water levels:

62-mm inside-diameter tubing that has a 3.7-m-long well screen on the bottom; tubing and attached screen extend from land surface to a depth of $419.4 \mathrm{~m}$; saturated interval of borehole is within the Prow Pass Tuff of the Crater Flat Group.

4. Information for calculating water-level altitude:

Reference point: Top of metal tag on well casing, altitude $1,124.06 \mathrm{~m}$ (surveyed by U.S. Geological Survey, 1984).

Measuring point: Top of access tube, $0.158 \mathrm{~m}$ above reference point.

Depth correction for borehole deviation from vertical: $0.482 \mathrm{~m}$, based on approximate depth to water of $394 \mathrm{~m}$ (1990 data). 


\section{Well UE-25 WT\#18}

Information about the history of well UE-25 WT\#18 and about previous data from the well was obtained from various sources. These sources are: Fenix \& Scisson, Inc. (1986a); Holmes \& Narver, Inc. (written commun., 1986); and Muller and Kibler (1985).

Well specifications

1. Location and identification:

Latitude and longitude: $36^{\circ} 52^{\prime} 07^{\prime \prime} \mathrm{N} ; 116^{\circ} 26^{\prime} 42^{\prime \prime} \mathrm{W}$.

Nevada State Central Zone Coordinates (m): N 235,052; E 172,168.

U.S. Geological Survey Site ID: 365207116264201.

2. Drilling and casing information:

Well started: May 9, 1984.

Well completed: May 23, 1984.

Drilling method: Rotary using rock bits and air-foam circulating medium; core obtained from bottom of the borehole.

Bit diameter below water level: $222 \mathrm{~mm}$.

Casing: Surface casing only, to a depth of $27 \mathrm{~m}$.

Total depth drilled: $623 \mathrm{~m}$.

3. Access to and description of depth interval for measuring water levels:

62-mm inside-diameter tubing that has a 3.7-m-long well screen on the bottom; tubing and attached screen originally extended from land surface to a depth of $597 \mathrm{~m}$, but tubing was extended to a depth of 609 m, December 1990; saturated interval is within the Calico Hills Formation.

4. Information for calculating water-level altitude:

Reference point: Top of metal tag on well casing, altitude $1336.32 \mathrm{~m}$ (surveyed by U.S. Geological Survey, 1984).

Measuring point: Top of access tube, $0.210 \mathrm{~m}$ above reference point.

Depth correction for borehole deviation from vertical: $0.155 \mathrm{~m}$, based on approximate depth to water of $607 \mathrm{~m}$ (1990 data). 


\section{Well UE-25 b\#1}

Information about the history of well UE-25b \#1 and about previous data from the well was obtained from various sources. These sources are: Lobmeyer and others (1983); Lahoud and others (1984); Robison (1984); Robison (U.S. Geological Survey, written commun., 1986); Robison and others (1988); and Fenix \& Scisson, Inc. (1986b, 1987c).

\section{Well specifications}

1. Location and identification:

Latitude and longitude: $36^{\circ} 51^{\prime} 08^{\prime \prime} \mathrm{N}$.; $116^{\circ} 26^{\prime} 23^{\prime \prime} \mathrm{W}$.

Nevada State Central Zone Coordinates (m): N 233,246; E 172,644.

U.S. Geological Survey Site ID: 365108116262301.

2. Drilling and casing information:

Well started: April 3, 1981.

Well completed: September 22, 1981.

Drilling method: Rotary, using rock bits and air-foam circulating medium; cores obtained from selected intervals.

Bit diameter below water level: $311 \mathrm{~mm}$ to $520 \mathrm{~m} ; 222 \mathrm{~mm}$ to $650 \mathrm{~m} ; 216 \mathrm{~mm}$ from 650 to $1,220 \mathrm{~m}$.

Casing extending below water level: $226-\mathrm{mm}$ inside diameter to $518 \mathrm{~m}$; casing string is tack cemented in and perforated below the water level.

Total drilled depth: $1,220 \mathrm{~m}$.

3. Access to and description of depth interval for measuring water levels:

\section{Upper interval:}

48-mm inside diameter tubing, open ended, to depth of about $488 \mathrm{~m}$; upper interval of borehole, from near water table to top of inflatable packer, is within the Calico Hills Formation, and Prow Pass, Bullfrog, and upper Tram Tuffs of the Crater Flat Group;

\section{Lower interval:}

62-mm inside diameter tubing that has an inflatable packer on bottom end, to depth of $1,199 \mathrm{~m}$; lower interval of borehole, from below packer to bottom of well, is within the lower Tram Tuff of the Crater Flat Group and Lithic Ridge Tuff.

4. Information for calculating water-level altitude:

Reference point: Top of metal tag on well casing; altitude $1,200.73 \mathrm{~m}$ (surveyed by U.S. Geological Survey, 1984).

Measuring point: Top of access tubes, $0.302 \mathrm{~m}$, upper interval; $0.134 \mathrm{~m}$, lower interval (all measuring points are above reference point).

Depth correction for borehole deviation from vertical: $0.244 \mathrm{~m}$, based on approximate depth to water of $470 \mathrm{~m}$ (1990 data). 


\section{Well UE-25 p\#1}

Information about the history of well UE-25p \#1 and about previous data from the well was obtained from various sources. These sources are: Craig and Johnson (1984); Craig and Robison (1984); Robison (1984); Robison (U.S. Geological Survey, written commun., 1986); Robison and others (1988); and Fenix \& Scisson, Inc. (1986c, 1987c).

\section{Well specifications}

1. Location and identification:

Latitude and longitude: $36^{\circ} 49^{\prime} 38^{\prime \prime} \mathrm{N}$.; $116^{\circ} 25^{\prime} 21^{\prime \prime} \mathrm{W}$.

Nevada State Central Zone Coordinates (m): N 230,481; E 174,188.

U.S. Geological Survey Site ID: 364938116252102.

2. Drilling and casing information:

Well started: November 13, 1982.

Well completed: May 24, 1983.

Drilling method: Rotary, using rock bits and air-foam circulating medium; cores obtained from selected intervals.

Bit diameter below water level: $375 \mathrm{~mm}$ to $487 \mathrm{~m} ; 251 \mathrm{~mm}$ from 487 to $1,304 \mathrm{~m}$; $17 \mathrm{~mm}$ from 1,304 to $1,317 \mathrm{~m} ; 171 \mathrm{~mm}$ from 1,317 to $1,798 \mathrm{~m} ; 156 \mathrm{~mm}$ from 1,798 to $1,805 \mathrm{~m}$.

Casing extending below water level: $255-\mathrm{mm}$ inside diameter from land surface to $477 \mathrm{~m} ; 177-\mathrm{mm}$ inside diameter from 453 to $1,297 \mathrm{~m}$; casing string is cemented in, has no perforations.

Total drilled depth: $1,805 \mathrm{~m}$.

3. Access to and description of depth interval for measuring water levels:

38-mm inside-diameter tubing, open end, to depth of $418 \mathrm{~m}$; well construction is such that water level of the tuffs of Tertiary age is not monitored. Only the water level in the underlying carbonate rocks of Palcozoic age is measured (Tertiary-Paleozoic contact is at 1,244 m).

Note: A 38-mm inside-diameter tubing, closed end, and filled with water, to a depth of $413 \mathrm{~m}$ below land surface is also installed in the well to allow access for temperature logging.

4. Information for calculating water-level altitude:

Reference point: Top of metal tag on well casing; altitude 1,114.21 m (surveyed by U.S. Geological Survey, 1984).

Measuring point: Top of access tube, $0.158 \mathrm{~m}$ above reference point.

Depth correction for borehole deviation from vertical: $0.021 \mathrm{~m}$, based on approximate depth to water of $362 \mathrm{~m}$ (1990 data). 


\section{Well USW VH-1}

Information about the history of well USW VH-1 and about previous data from the well was obtained from various sources. These sources are: Robison (1984); Robison (U.S. Geological Survey, written commun., 1986); Robison and others (1988); Holmes \& Narver, Inc. (written commun., 1986); Fenix \& Scisson, Inc. (1986b, 1987c); and Thordarson and Howells (1987).

Well specifications

1. Location and identification:

Latitude and longitude: $36^{\circ} 47^{\prime} 32^{\prime \prime N}$.; $116^{\circ} 33^{\prime} 07^{\prime \prime} \mathrm{W}$.

Nevada State Central Zone Coordinates (m): N 226,575; E 162,649.

U.S. Geological Survey Site ID: 364732116330701.

2. Drilling and casing information:

Well started: October 28, 1980.

Well completed: February 18, 1981.

Drilling method: Rotary, using rock bits, and air-foam and polymer circulating medium.

Bit diameter below water level: $222 \mathrm{~mm}$ to $278 \mathrm{~m} ; 1.59 \mathrm{~mm}$ from $278 \mathrm{~m}$ to total depth.

Casing extending below water level: $177-\mathrm{mm}$ inside diameter to $278 \mathrm{~m}$.

Total drilled depth: $762 \mathrm{~m}$.

3. Access to and description of depth interval for measuring water levels:

48-mm inside-diameter tubing, open ended from land surface to $205.4 \mathrm{~m}$; saturated interval of the well is within the Tiva Canyon and Topopah Spring Tuffs of the Paintbrush Group, and the Prow Pass and Bullfrog Tuffs of the Crater Flat Group. A pump was installed in the well on July 8, 1982, at a depth of $212.8 \mathrm{~m}$.

4. Information for calculating water-level altitude:

Reference point: Top of metal tag on well casing, altitude $963.23 \mathrm{~m}$ (surveyed by

Holmes \& Narver, Inc., March 3, 1986).

Measuring point: Top of access tube, $0.631 \mathrm{~m}$ above reference point.

Depth correction for borehole deviation from vertical: $0.049 \mathrm{~m}$, based on approximate depth to water of $184 \mathrm{~m}$ (1990 data). 


\section{Well USW G-2}

Information about the history of well USW G-2 and about previous data from the well was obtained from various sources. These sources are: Maldonado and Koether (1983); Robison (1984); Robison (U.S. Geological Survey, written commun., 1986); Robison and others (1988); Holmes \& Narver, Inc. (written commun., 1986); Fenix \& Scisson, Inc. (1987b, 1987c); and Nelson and Schimschal (1993).

\section{Well specifications}

1. Location and identification:

Latitude and longitude: $36^{\circ} 53^{\prime} 22^{\prime \prime} \mathrm{N} . ; 116^{\circ} 27^{\prime} 35^{\prime \prime} \mathrm{W}$.

Nevada State Central Zone Coordinates (m): N 778,825; E 560,503.

U.S. Geological Survey Site ID: 365322116273501.

2. Drilling and casing information:

Well started: March 25, 1981.

Well completed: October 24, 1981.

Drilling method: Rotary, using rock bits, with polymer mud to $88 \mathrm{~m}$; cored from $88 \mathrm{~m}$ to total depth.

Bit diameter below water level: $222 \mathrm{~mm}$ to $814 \mathrm{~m} ; 159 \mathrm{~mm}$ from $814 \mathrm{~m}$ to $947 \mathrm{~m}$; $156 \mathrm{~mm}$ from 947 to $1,439 \mathrm{~m} ; 76 \mathrm{~mm}$ from $1,439 \mathrm{~m}$ to total depth.

Casing extending below water level: None (surface casing, $320 \mathrm{~mm}$ inside diameter, $0-85 \mathrm{~m}$ and $276 \mathrm{~mm}$ inside diameter, 0-242 $\mathrm{m}$ ).

Total drilled depth: $1,831 \mathrm{~m}$.

3. Access to and description of depth interval for measuring water levels:

Saturated interval of borehole is within the Topopah Springs Tuff of the Paintbrush Group, the Calico Hills Formation, and Prow Pass, Bullfrog, and Tram Tuffs of the Crater Flat Group, Lithic Ridge Tuff, and older flows and tuffs. Bridge plug at a depth of $806 \mathrm{~m}$. Second bridge plug installed in well on September 29, 1995. Top of second bridge plug at a depth of $792 \mathrm{~m}$.

Until October 1995, measurements were made through the well casing. On October 3, 1995, a $51-\mathrm{mm}$ open-ended tubing extending from land surface to $597 \mathrm{~m}$ was installed in well.

4. Information for calculating water-level altitude:

Reference point: Top of metal tag on well casing, altitude $1,553.86 \mathrm{~m}$ (surveyed by U.S. Geological Survey, 1984).

Measuring point: Top of casing, $0.034 \mathrm{~m}$ before February 3, 1993, $0.332 \mathrm{~m}$ from February 3, 1993 to October 1, 1995. Monitoring tube placed in well on October 3, 1995. Measuring point changed to top of monitoring tube. Measuring point after October 1, 1995, was $0.20 \mathrm{~m}$. All measuring points above reference point.

Depth correction for borehole deviation from vertical: $0.158 \mathrm{~m}$, based on approximate depth to water $524 \mathrm{~m}$ (1984 data) through December 31, 1994. After January 1, 1995, depth correction for borehole deviation from vertical: $0.192 \mathrm{~m}$, based on approximate depth to water of $534 \mathrm{~m}$ (1994 data). 


\section{Well USW G-3}

Information about the history of well USW G-3 and about previous data from the well was obtained from various sources. These sources are: Robison (1984); Robison (U.S. Geological Survey, written commun., 1986); Robison and others (1988); and Fenix \& Scisson, Inc. (1987b, 1987c).

\section{Well specifications}

1. Location and identification:

Latitude and longitude: $36^{\circ} 49^{\prime} 05^{\prime \prime} \mathrm{N}$.; $116^{\circ} 28^{\prime} 01^{\prime \prime} \mathrm{W}$.

Nevada State Central Zone Coordinates (m): N 229,447; E 170,226.

U.S. Geological Survey Site ID: 364905116280101.

2. Drilling and casing information:

Well started: January 8, 1982.

Well completed: March 21, 1982.

Drilling method: Rotary, using mostly air-foam, and occasional polymer added

for circulating medium; many drilling problems encountered in upper part of hole, including lost circulation and lost or stuck tools; hole cored from $795 \mathrm{~m}$ to total drilled depth.

Bit diameter below water level: $222 \mathrm{~mm}$ to $792 \mathrm{~m} ; 121 \mathrm{~mm}$ from 792 to $795 \mathrm{~m}$; $100 \mathrm{~mm}$ from $795 \mathrm{~m}$ to total drilled depth. Casing extending below water level: $126-\mathrm{mm}$ inside diameter to $792 \mathrm{~m}$; bottom casing back cemented; no perforations.

Total drilled depth: $1,533 \mathrm{~m}$.

3. Access to and description of depth interval for measuring water levels:

Casing, 126-mm inside diameter, extending from land surface to a depth of $792 \mathrm{~m}$; saturated interval of borehole is within the Tram Tuff of the Crater Flat Group and the Lithic Ridge Tuff.

4. Information for calculating water-level altitude:

Reference point: Top of metal tag on well casing; altitude 1,480.47 m (surveyed by U.S. Geological Survey, 1984).

Measuring point: Top of access tube, $0.329 \mathrm{~m}$ above reference point.

Depth correction for borehole deviation from vertical: $0.564 \mathrm{~m}$, based on approximate depth to water of $750 \mathrm{~m}$ (1990 data). 


\section{Well J-11}

Information about the history of well USW J-11 and about previous data from the well was obtained from Young, R.A. (1972) and Fenix \& Scisson, Inc. (1987c).

\section{Well specifications}

1. Location and identification:

Latitude and longitude: $36^{\circ} 47^{\prime} 06^{\prime \prime} \mathrm{N}$.; $116^{\circ} 17^{\prime} 06^{\prime \prime} \mathrm{W}$.

Nevada State Central Zone Coordinates (m): N 740,968; E 611,764.

U.S. Geological Survey Site ID: 364706116170601.

2. Drilling and casing information:

Well started: June 4, 1957.

Well completed: July 19, 1957.

Drilling method: Cable-tool.

Bit diameter below water level: $400 \mathrm{~mm}$.

Casing extending below water level: $308-\mathrm{mm}$ inside-diameter casing extends from land surface to $404.5 \mathrm{~m}$.

Total drilled depth: $405 \mathrm{~m}$.

3. Access to and description of depth interval for measuring water levels:

308-mm inside-diameter casing; the casing is perforated from 328.3 to $334.4 \mathrm{~m}$ and from 379.2 to $396.2 \mathrm{~m}$. The well produces water from the basalt of Kiwi Mesa and from the welded-tuff aquifer, located within the Topopah Spring Tuff of the Paintbrush Group.

4. Information for calculating water-level altitude:

Reference point: Chiseled " $X$ " in concrete pad near well; altitude 1,049.45 m (surveyed by U.S. Geological Survey, 1993).

Measuring point: Top of casing, even with top of concrete block, $0.555 \mathrm{~m}$ above reference point.

Depth correction for borehole deviation from vertical is not available. 


\section{Well J-12}

Information about the history of well USW J-12 and about previous data from the well was obtained from Young, R.A. (1972) and Fenix \& Scisson, Inc. (1987c).

Well specifications

1. Location and identification:

Latitude and longitude: $36^{\circ} 45^{\prime} 54^{\prime \prime N}$.; $116^{\circ} 23^{\prime} 24^{\prime \prime} \mathrm{W}$.

Nevada State Central Zone Coordinates (m): N 733,508; E 581,012.

U.S. Geological Survey Site ID: 364554116232401.

2. Drilling and casing information:

Well started: August 4, 1957.

Well completed: October 9, 1957; well was deepened in August 1968.

Drilling method: Cable-tool (1957); unknown 1968.

Bit diameter below water level: $400-\mathrm{mm}$ to $271 \mathrm{~m}, 298-\mathrm{mm}$ to $347 \mathrm{~m}$.

Casing extending below water level: $308-\mathrm{mm}$ inside-diameter casing extending from land surface to $271 \mathrm{~m}$.

Total drilled depth: $271 \mathrm{~m}$ (1957); $347 \mathrm{~m}$ after the deepening in 1968.

3. Access to and description of depth interval for measuring water levels:

308-mm inside-diameter casing; the casing is perforated between $241-264 \mathrm{~m}$; the hole is open from $271 \mathrm{~m}$ to $347 \mathrm{~m}$; access tube is 54-mm outside-diameter. The well produces water from the weldedtuff aquifer, located within the Topopah Spring Tuff of the Paintbrush Group.

4. Information for calculating water-level altitude:

Reference point: Top of well collar, altitude $954.54 \mathrm{~m}$ (surveyed by U.S. Geological Survey, 1993).

Measuring point: Top of the 54-mm outside-diameter access tube, $0.527 \mathrm{~m}$ above reference point.

Depth correction for borehole deviation from vertical is not available. 


\section{Well J-13}

Information about the history of well J-13 and about previous data from the well was obtained from various sources. These sources are: Robison (1984); Robison (U.S. Geological Survey, written commun., 1986); Robison and others (1988); Holmes \& Narver, Inc. (written commun., 1986); Thordarson (1983); Young (1972); and Fenix \& Scisson (1987c).

\section{Well specifications}

1. Location and identification:

Latitude and longitude: $36^{\circ} 48^{\prime} 29^{\prime \prime} \mathrm{N}$.; $116^{\circ} 23^{\prime} 40^{\prime \prime} \mathrm{W}$.

Nevada State Central Zone Coordinates (m): N 228,359; E 176,678.

U.S. Geological Survey Site ID: 364828116234001.

2. Drilling and casing information:

Well started: September 12, 1962.

Well completed: January 8, 1963.

Drilling method: Rotary, using air and aerated mud as circulating medium.

Bit diameter below water level: $438 \mathrm{~mm}$ to $402 \mathrm{~m} ; 380 \mathrm{~mm}$ from $402 \mathrm{~m}$ to $471 \mathrm{~m}$; $194 \mathrm{~mm}$ from $471 \mathrm{~m}$ to total depth.

Casing extending below water level: $323-\mathrm{mm}$ inside diameter, from land surface to $396.5 \mathrm{~m} ; 282$-mm inside diameter from 396.5 to $471.2 \mathrm{~m} ; 126-\mathrm{mm}$ inside diameter from 452.3 to $1,031.7 \mathrm{~m}$; casing perforated from 303.6 to $423.7 \mathrm{~m}$ is within the Topopah Spring Tuff of the Paintbrush Group, and from 819.9 to $1,009.5 \mathrm{~m}$ is within the Tram Tuff of the Crater Flat Group and upper part of the Lithic Ridge Tuff.

Total drilled depth: $1,063 \mathrm{~m}$.

3. Access to and description of depth interval for measuring water levels:

50.8-mm inside-diameter access tube, installed in 1986, in order for measuring equipment to bypass pump assembly.

4. Information for calculating water-level altitude:

Reference point: Chiseled square on concrete well collar, altitude $1,011.47 \mathrm{~m}$ (surveyed by U.S. Geological Survey, 1984).

Measuring point: Top of access tube, $0.165 \mathrm{~m}$ above reference point.

Depth correction for borehole deviation from vertical is not available. 


\section{Well USW H-1}

Information about the history of well USW H-1 and about previous data from the well was obtained from various sources. These sources are: Rush and others (1983); Rush and others (1984); Robison (1984); Robison (U.S. Geological Survey, written commun., 1986); Robison and others (1988); and Fenix \& Scisson, Inc. (1987a, 1987c).

\section{Well specifications}

1. Location and identification:

Latitude and longitude: $36^{\circ} 51^{\prime} 57^{\prime \prime N}$.; $116^{\circ} 27^{\prime} 12^{\prime \prime} \mathrm{W}$.

Nevada State Central Zone Coordinates (m): N 234,774; E 171,416.

U.S. Geological Survey Site ID: 365157116271201.

2. Drilling and casing information:

Well started: September 3, 1980.

Well completed: January 25, 1981 (initial completion, including geophysical logging and hydraulic testing); July 6, 1982 (re-completion; four piezometers installed).

Drilling method: Rotary, using rock bits and air-foam circulating medium; cores obtained from selected intervals.

Bit diameter below water level: $311 \mathrm{~mm}$ to $688 \mathrm{~m} ; 222 \mathrm{~mm}$ from $688 \mathrm{~m}$ to $1,829 \mathrm{~m}$.

Casing extending below water level: 226-mm inside diameter to $687 \mathrm{~m}$. Casing string is tack cemented and perforated below the water table. See section 3 for description of intervals open to water.

Total drilled depth: $1,829 \mathrm{~m}$.

3. Access to and description of depth interval for measuring water levels:

Tube 1:

44-mm inside diameter, that has a 3.6-m-long well screen on bottom, extending from land surface to depth of $1,806 \mathrm{~m}$; responds to depth interval from 1,783 to $1,814 \mathrm{~m}$ within older flows and tuffs beneath the Lithic Ridge Tuff;

\section{Tube 2:}

$44 \mathrm{~mm}$ inside diameter, that has a 3.6-m-long well screen on bottom, extending from land surface to depth of $1,115 \mathrm{~m}$; responds to depth interval from 1,097 to 1,123 m within the Tram Tuff of the Crater Flat Group, and lava flow and flow breccia beneath the Tram Tuff;

\section{Tube 3:}

44-mm inside diameter, that has a 3.6-m-long well screen on bottom, extending from land surface to depth of $741 \mathrm{~m}$; responds to depth interval from 716 to $765 \mathrm{~m}$ within the Bullfrog Tuff of the Crater Flat Group;

Tube 4:

62-mm inside diameter, open ended, extending from land surface to depth of $640 \mathrm{~m}$; responds to depth interval from 572 to $673 \mathrm{~m}$ within the Prow Pass Tuff of the Crater Flat Group. 
Note: During re-completion, a gravel pack was placed in the vicinity of the well screens for tubes 1,2, and 3; and other intervals were grouted with cement to ensure that the piezometers are hydraulically isolated from each other.

4. Information for calculating water-level altitude:

Reference point: Top of metal tag on well casing; altitude 1,303.10 m (surveyed by U.S. Geological Survey, 1984).

Measuring point: Top of access tubes, $0.311 \mathrm{~m}$ above reference point, all intervals.

Depth correction for borehole deviation from vertical: $0.143 \mathrm{~m}$ in tube 1 , based on approximate depth to water of $518 \mathrm{~m}$ (1990 data); $0.171 \mathrm{~m}$ in tube 2, based on approximate depth to water of $567 \mathrm{~m}$ (1993 data); $0.174 \mathrm{~m}$ in tubes 3 and 4 , based on approximate depths to water of $572 \mathrm{~m}$ (1990 data). 


\section{Well USW H-3}

Information about the history of well USW H-3 and about previous data from the well was obtained from various sources. These sources are: Thordarson, Rush, Spengler, and Waddell (1984); Thordarson, Rush, and Waddell (1984); Robison (1984); Robison (U.S. Geological Survey, written commun., 1986); Robison and others (1988); and Fenix \& Scisson, Inc. (1987a, 1987c).

\section{Well specifications}

1. Location and identification:

Latitude and longitude: $36^{\circ} 49^{\prime} 42^{\prime \prime N}$; $116^{\circ} 28^{\prime} 00^{\prime \prime} \mathrm{W}$.

Nevada State Central Zone Coordinates (m): N 230,594; E 170,216.

U.S. Geological Survey Site ID: 364942116280001.

2. Drilling and casing information:

Well started: January 27, 1982.

Well completed: March 19, 1982.

Drilling method: Rotary, using rock bits and air-foam circulating medium.

Bit diameter below water level: $375 \mathrm{~mm}$ to $808 \mathrm{~m} ; 222 \mathrm{~m}$ from $808 \mathrm{~m}$ to $1,219 \mathrm{~m}$.

Casing extending below water level: $253 \mathrm{~mm}$ diameter to $792 \mathrm{~m}$, not perforated below the water level.

Total drilled depth: $1,219 \mathrm{~m}$.

3. Access to and description of depth intervals for measuring water levels:

\section{Upper interval:}

41-mm inside diameter open ended tubing, extending from land surface to depth of about $762 \mathrm{~m}$; upper interval of well, from near water table to top of inflatable packer, is within bedded tuff and the Tram Tuff of the Crater Flat Group;

\section{Lower interval:}

62-mm inside diameter tubing that has an inflatable packer on bottom end extending from land surface to $1,061 \mathrm{~m}$; lower interval from below packer to bottom of well, is within the Tram Member of the Crater Flat Tuff and the Lithic Ridge Tuff.

Note: Inflatable packer installed January 1983 at a depth of $1,190 \mathrm{~m}$; removed late November 1983 during period of additional hydraulic testing; reinstalled during May 1984 at depth of 1,114 m; removed and reinstalled during December 1990 at a depth of $1,061 \mathrm{~m}$.

4. Information for calculating water-level altitude:

Reference point: Top of metal tag on well casing; altitude $1483.47 \mathrm{~m}$ (surveyed by U.S. Geological Survey, 1984).

Measuring point: Top of access tubes, $0.174 \mathrm{~m}$, upper interval; $0.201 \mathrm{~m}$, lower interval (all measuring points are above reference point).

Depth correction for borehole deviation from vertical: $0.079 \mathrm{~m}$, upper interval, based on approximate depth to water of $752 \mathrm{~m}$ (1990 data); $0.058 \mathrm{~m}$, lower interval, based on approximate depth to water of $728 \mathrm{~m}$ (1990 data). 


\section{Well USW H-4}

Information about the history of well USW H-4 and about previous data from the well was obtained from various sources. These sources are: Whitfield and others (1984); Whitfield and others (1985);

Robison (1984); Robison (U.S. Geological Survey, written commun., 1986); Robison and others (1988); Erickson and Waddell (1985); and Fenix \& Scisson, Inc. (1987a, 1987c).

\section{Well specifications}

1. Location and identification:

Latitude and longitude: $36^{\circ} 50^{\prime} 32^{\prime \prime} \mathrm{N} . ; 116^{\circ} 26^{\prime} 54^{\prime \prime} \mathrm{W}$.

Nevada State Central Zone Coordinates (m): N 232,149; E 171,880.

U.S. Geological Survey Site ID: 365032116265401.

2. Drilling and casing information:

Well started: March 22, 1982.

Well completed: June 7, 1982.

Drilling method: Rotary, using rock bits and air-foam circulating medium; cores obtained from selected intervals.

Bit diameter below water level: $375 \mathrm{~mm}$ to $564 \mathrm{~m} ; 222 \mathrm{~mm}$ from $564 \mathrm{~m}$ to $1,219 \mathrm{~m}$.

Casing extending below water level: $253 \mathrm{~mm}$ diameter to $561 \mathrm{~m}$, perforated below the water level.

Total drilled depth: $1,219 \mathrm{~m}$.

3. Access to and description of depth interval for measuring water levels:

\section{Upper interval:}

48-mm inside diameter open-ended tubing, extending from land surface to depth of $525 \mathrm{~m}$; upper interval of well near water table to top of inflatable packer is within the Prow Pass, Bullfrog, and Tram Tuffs of the Crater Flat Group, bedded tuff, and upper Lithic Ridge Tuff;

\section{Lower interval:}

62-mm inside diameter tubing with inflatable packer on bottom end, extending from surface to $1,188 \mathrm{~m}$; lower interval of well is within the Lithic Ridge Tuff.

4. Information for calculating water-level altitude:

Reference point: Top of metal tag on well casing; altitude 1,248.74 m (surveyed by U.S. Geological Survey, 1984).

Measuring point: Top of access tubes, $0.597 \mathrm{~m}$, upper interval; $0.308 \mathrm{~m}$, lower interval all (measuring points are above reference point).

Depth correction for borehole deviation from vertical: $0.064 \mathrm{~m}$, based on approximate depth to water of $518 \mathrm{~m}$ (1990 data). 


\section{Well USW H-5}

Information about the history of well USW H-5 and about previous data from the well was obtained from various sources. These sources are: Bentley and others (1983); Robison (1984); Robison (U.S. Geological Survey, written commun., 1986); Robison and others (1988); and Fenix \& Scisson, Inc. (1987a, 1987c).

\section{Well specifications}

1. Location and identification:

Latitude and longitude: $36^{\circ} 51^{\prime 2} 22^{\prime \prime} \mathrm{N}$.; $116^{\circ} 27^{\prime} 55^{\prime \prime} \mathrm{W}$.

Nevada State Central Zone Coordinates (m): N 233,670; E 170,355.

U.S. Geological Survey Site ID: 365122116275502.

2. Drilling and casing information:

Well started: May 19, 1982.

Well completed: August 1, 1982.

Drilling method: Rotary, using rock bits and air-foam circulating medium; cores obtained from selected intervals.

Bit diameter below water level: $375 \mathrm{~mm}$ to $792 \mathrm{~m} ; 222 \mathrm{~mm}$ from $792 \mathrm{~m}$ to $1,219 \mathrm{~m}$.

Casing extending below water level: $255 \mathrm{~mm}$ diameter to $788 \mathrm{~m}$, perforated below the water level.

Total drilled depth: $1,219 \mathrm{~m}$.

3. Access to and description of depth interval for measuring water levels:

\section{Upper interval:}

48-mm inside-diameter open-ended tubing, extending from land surface to a depth of $709 \mathrm{~m}$; upper saturated interval of the borehole is within the Bullfrog and Tram Tuffs of the Crater Flat Group, bedded tuff, and unnamed lava beneath the Tram Tuff (Carr, 1988, p. 37) (Sawyer and others, 1994, p. 1305);

\section{Lower interval:}

62-mm inside-diameter tubing that has a 3.6-m-long inflatable packer on bottom end, extending from land surface to $846 \mathrm{~m}$; lower interval is within the Tram Tuff of the Crater Flat Group, and within an unnamed lava unit below the Tram Tuff (Carr, 1988, p. 37) (Sawyer and others, 1994, p. 1305).

Note: The packer was reset at its present depth $(846 \mathrm{~m})$ on $3 / 25 / 93$, from its previous depth of 1,091 m (G.M. O’Brien, U.S. Geological Survey, written commun., 1993).

4. Information for calculating water-level altitude:

Reference point: Top of metal tag on well casing; altitude 1,478.94 m (surveyed by U.S. Geological Survey, 1984).

Measuring point: Top of access tubes, $0.329 \mathrm{~m}$, upper interval; $0.235 \mathrm{~m}$, lower interval (all measuring points are above reference point).

Depth correction for borehole deviation from vertical: $0.079 \mathrm{~m}$, based on approximate depth to water of $703 \mathrm{~m}$ (1990 data). 


\section{Well USW H-6}

Information about the history of well USW H-6 and about previous data from the well was obtained from various sources. These sources are: Craig and others (1983); Robison (1984); Robison (U.S. Geological Survey, written commun., 1986); Robison and others (1988); and Fenix \& Scisson, Inc. (1987a, 1987c).

\section{Well specifications}

1. Location and identification:

Latitude and longitude: $36^{\circ} 50^{\prime} 49^{\prime \prime} \mathrm{N}$.; $116^{\circ} 28^{\prime} 55^{\prime \prime} \mathrm{W}$.

Nevada State Central Zone Coordinates (m): N 232,654; E 168,882.

U.S. Geological Survey Site ID: 365049116285501.

2. Drilling and casing information:

Well started: August 7, 1982.

Well completed: October 28, 1982.

Drilling method: Rotary, using rock bits and air-foam circulating medium; cores obtained from selected intervals.

Bit diameter below water level: $375 \mathrm{~mm}$ to $583 \mathrm{~m} ; 222 \mathrm{~mm}$ from 583 to $1,216 \mathrm{~m}$; $156 \mathrm{~mm}$ from $1,216 \mathrm{~m}$ to $1,220 \mathrm{~m}$.

Casing extending below water level: $250-\mathrm{mm}$ diameter to $581 \mathrm{~m}$, perforated below the water level.

Total drilled depth: $1,220 \mathrm{~m}$.

3. Access to and description of depth interval for measuring water levels:

\section{Upper interval:}

48-mm inside diameter open-ended tubing, extending from land surface to $533 \mathrm{~m}$; saturated upper interval is within the Prow Pass, Bullfrog, and Tram Tuffs of the Crater Flat Group, and bedded tuff;

\section{Lower interval:}

62-mm inside diameter tubing with inflatable packer on bottom end, extending from land surface to $752 \mathrm{~m}$; lower interval is within the Tram Tuff of the Crater Flat Group, bedded tuff, an unnamed lava between the Tram Tuff and Lithic Ridge Tuff, (Carr, 1988 p. 37) (Sawyer and others, 1994, p. 1305) and the Lithic Ridge Tuff.

4. Information for calculating water-level altitude:

Reference point: Top of metal tag on well casing; altitude 1,302.06 m (surveyed by U.S. Geological Survey, 1984).

Measuring point: Top of access tubes, $0.207 \mathrm{~m}$, upper interval; $0.235 \mathrm{~m}$, lower interval (all measuring points are above reference point).

Depth correction for borehole deviation from vertical: $0.052 \mathrm{~m}$, based on approximate depth to water of $526 \mathrm{~m}$ (1990 data). 


\section{APPENDIX B}

This section contains all manual water-level measurements and monthly mean water levels used to plot hydrographs in this report. All statistical analyses were derived from this data. Dates are formatted year-month-day. This format was chosen to make the data compatible with the graphics program used to plot the final hydrographs. 


\section{Well USW WT-1}

[M, indicates manual water-level measurement; $\mathrm{H}$, indicates monthly mean water levels averaged from hourly transducer data]

\begin{tabular}{|c|c|c|c|c|c|}
\hline $\begin{array}{c}\text { Date }^{1} \\
\text { (year-month-day) }\end{array}$ & $\begin{array}{c}\text { Water-level } \\
\text { altitude } \\
\text { (meters) }\end{array}$ & $\begin{array}{c}\text { Date }^{1} \\
\text { (year-month-day) }\end{array}$ & $\begin{array}{c}\text { Water-level } \\
\text { altitude } \\
\text { (meters) }\end{array}$ & $\begin{array}{c}\text { Date }^{1} \\
\text { (year-month-day) }\end{array}$ & $\begin{array}{c}\text { Water-level } \\
\text { altitude } \\
\text { (meters) }\end{array}$ \\
\hline $85-01-18$ & $730.06 \mathrm{M}$ & $88-03-21$ & $730.37 \mathrm{M}$ & $93-03-11$ & $730.29 \mathrm{M}$ \\
\hline $85-02-04$ & $729.98 \mathrm{M}$ & $88-04-25$ & $730.40 \mathrm{M}$ & $93-04-23$ & $730.34 \mathrm{M}$ \\
\hline $85-02-26$ & $730.01 \mathrm{M}$ & $88-05-23$ & $730.44 \mathrm{M}$ & $93-05-12$ & $730.35 \mathrm{M}$ \\
\hline $85-03-21$ & $730.04 \mathrm{M}$ & $88-06-28$ & $730.42 \mathrm{M}$ & $93-06-17$ & $730.27 \mathrm{M}$ \\
\hline $85-03-27$ & $730.09 \mathrm{M}$ & $88-07-11$ & $730.42 \mathrm{M}$ & $93-11-19$ & $730.22 \mathrm{M}$ \\
\hline $85-04-11$ & $730.04 \mathrm{M}$ & $88-08-12$ & $730.40 \mathrm{M}$ & $93-12-29$ & $730.25 \mathrm{M}$ \\
\hline $85-06-13$ & $730.28 \mathrm{M}$ & $88-09-14$ & $730.37 \mathrm{M}$ & $94-02-02$ & $730.29 \mathrm{M}$ \\
\hline $85-08-05$ & $730.42 \mathrm{M}$ & $88-10-27$ & $730.42 \mathrm{M}$ & $94-03-01$ & $730.20 \mathrm{M}$ \\
\hline $85-11-20$ & $730.50 \mathrm{M}$ & $88-12-20$ & $730.42 \mathrm{M}$ & $94-03-16$ & $730.33 \mathrm{M}$ \\
\hline $85-12-27$ & $730.50 \mathrm{M}$ & 89-01-09 & $730.37 \mathrm{M}$ & $94-05-02$ & $730.28 \mathrm{M}$ \\
\hline $86-01-27$ & $730.35 \mathrm{M}$ & $89-02-22$ & $730.40 \mathrm{M}$ & $94-05-26$ & $730.29 \mathrm{M}$ \\
\hline $86-02-12$ & $730.34 \mathrm{M}$ & $89-03-13$ & $730.42 \mathrm{M}$ & $94-06-03$ & $730.30 \mathrm{M}$ \\
\hline $86-03-20$ & $730.22 \mathrm{M}$ & $89-04-25$ & $730.41 \mathrm{M}$ & $94-07-15$ & $730.31 \mathrm{H}$ \\
\hline $86-04-03$ & $730.35 \mathrm{M}$ & $89-05-24$ & $730.41 \mathrm{M}$ & $94-08-15$ & $730.33 \mathrm{H}$ \\
\hline $86-05-15$ & $730.39 \mathrm{M}$ & $89-06-30$ & $730.42 \mathrm{M}$ & $94-09-15$ & $730.34 \mathrm{H}$ \\
\hline $86-05-23$ & $730.28 \mathrm{M}$ & $89-07-19$ & $730.43 \mathrm{M}$ & $94-10-15$ & $730.34 \mathrm{H}$ \\
\hline $86-06-12$ & $730.32 \mathrm{M}$ & 89-08-09 & $730.40 \mathrm{M}$ & $94-11-15$ & $730.33 \mathrm{H}$ \\
\hline $86-07-08$ & $730.31 \mathrm{M}$ & $89-10-02$ & $730.49 \mathrm{M}$ & $94-12-15$ & $730.33 \mathrm{H}$ \\
\hline $86-08-11$ & $730.29 \mathrm{M}$ & $89-11-16$ & $730.43 \mathrm{M}$ & $95-01-15$ & $730.33 \mathrm{H}$ \\
\hline $86-08-29$ & $730.31 \mathrm{M}$ & $89-12-27$ & $730.44 \mathrm{M}$ & $95-02-15$ & $730.30 \mathrm{H}$ \\
\hline $86-09-14$ & $730.31 \mathrm{M}$ & $90-01-22$ & $730.41 \mathrm{M}$ & $95-03-15$ & $730.28 \mathrm{H}$ \\
\hline $86-10-01$ & $730.36 \mathrm{M}$ & $90-02-09$ & $730.38 \mathrm{M}$ & $95-04-15$ & $730.30 \mathrm{H}$ \\
\hline $86-10-29$ & $730.29 \mathrm{M}$ & $90-03-06$ & $730.42 \mathrm{M}$ & $95-05-15$ & $730.31 \mathrm{H}$ \\
\hline $86-11-29$ & $730.35 \mathrm{M}$ & $90-04-10$ & $730.39 \mathrm{M}$ & $95-06-15$ & $730.30 \mathrm{H}$ \\
\hline $86-12-11$ & $730.33 \mathrm{M}$ & $90-05-22$ & $730.45 \mathrm{M}$ & $95-07-15$ & $730.33 \mathrm{H}$ \\
\hline $86-12-26$ & $730.32 \mathrm{M}$ & $90-06-21$ & $730.47 \mathrm{M}$ & $95-08-15$ & $730.34 \mathrm{H}$ \\
\hline $87-01-13$ & $730.37 \mathrm{M}$ & $90-07-23$ & $730.44 \mathrm{M}$ & $95-09-27$ & $730.33 \mathrm{M}$ \\
\hline $87-01-26$ & $730.29 \mathrm{M}$ & $90-08-10$ & $730.41 \mathrm{M}$ & $95-12-12$ & $730.35 \mathrm{M}$ \\
\hline $87-02-12$ & $730.33 \mathrm{M}$ & $90-09-13$ & $730.45 \mathrm{M}$ & & \\
\hline $87-03-10$ & $730.35 \mathrm{M}$ & $90-10-22$ & $730.42 \mathrm{M}$ & & \\
\hline $87-04-08$ & $730.36 \mathrm{M}$ & $90-11-30$ & $730.42 \mathrm{M}$ & & \\
\hline $87-05-28$ & $730.33 \mathrm{M}$ & $90-12-14$ & $730.43 \mathrm{M}$ & & \\
\hline $87-06-08$ & $730.39 \mathrm{M}$ & $91-01-24$ & $730.44 \mathrm{M}$ & & \\
\hline $87-06-24$ & $730.32 \mathrm{M}$ & $91-02-27$ & $730.48 \mathrm{M}$ & & \\
\hline $87-07-13$ & $730.35 \mathrm{M}$ & $91-03-29$ & $730.39 \mathrm{M}$ & & \\
\hline $87-07-28$ & $730.35 \mathrm{M}$ & $91-04-25$ & $730.43 \mathrm{M}$ & & \\
\hline $87-08-25$ & $730.33 \mathrm{M}$ & $91-05-13$ & $730.41 \mathrm{M}$ & & \\
\hline $87-10-28$ & $730.36 \mathrm{M}$ & $91-06-14$ & $730.41 \mathrm{M}$ & & \\
\hline $87-11-30$ & $730.38 \mathrm{M}$ & $91-07-24$ & $730.41 \mathrm{M}$ & & \\
\hline $87-12-23$ & $730.40 \mathrm{M}$ & $91-08-26$ & $730.42 \mathrm{M}$ & & \\
\hline $88-01-26$ & $730.38 \mathrm{M}$ & $91-09-25$ & $730.38 \mathrm{M}$ & & \\
\hline $88-02-26$ & $730.39 \mathrm{M}$ & & & & \\
\hline
\end{tabular}

${ }^{1}$ Actual date of measurement applies to manual measurements only. For monthly mean water levels, the 15 th of each month was used. This was done to facilitate the plotting of the hydrographs for this report. 


\section{Well USW WT-2}

[M, indicates manual water-level measurement; $\mathrm{H}$, indicates monthly mean water levels averaged from hourly transducer data]

\begin{tabular}{|c|c|c|c|c|c|}
\hline $\begin{array}{c}\text { Date }^{1} \\
\text { (year-month-day) }\end{array}$ & $\begin{array}{l}\text { Water-level } \\
\text { altitude } \\
\text { (meters) }\end{array}$ & $\begin{array}{c}\text { Date }^{1} \\
\text { (year-month-day) }\end{array}$ & $\begin{array}{c}\text { Water-level } \\
\text { altitude } \\
\text { (meters) }\end{array}$ & $\begin{array}{c}\text { Date }^{1} \\
\text { (year-month-day) }\end{array}$ & $\begin{array}{c}\text { Water-level } \\
\text { altitude } \\
\text { (meters) }\end{array}$ \\
\hline $85-01-15$ & $730.29 \mathrm{M}$ & $90-01-15$ & $730.78 \mathrm{H}$ & $93-09-09$ & $730.62 \mathrm{M}$ \\
\hline $85-01-28$ & $730.28 \mathrm{M}$ & $90-02-15$ & $730.77 \mathrm{H}$ & $93-10-21$ & $730.69 \mathrm{M}$ \\
\hline $85-02-07$ & $730.30 \mathrm{M}$ & $90-03-15$ & $730.79 \mathrm{H}$ & $93-12-15$ & $730.51 \mathrm{H}$ \\
\hline $85-02-19$ & $730.35 \mathrm{M}$ & $90-04-15$ & $730.79 \mathrm{H}$ & $94-01-15$ & $730.52 \mathrm{H}$ \\
\hline $85-03-16$ & $730.32 \mathrm{M}$ & $90-05-15$ & $730.80 \mathrm{H}$ & $94-02-15$ & $730.53 \mathrm{H}$ \\
\hline $85-03-20$ & $730.14 \mathrm{M}$ & $90-06-15$ & $730.78 \mathrm{H}$ & $94-03-15$ & $730.52 \mathrm{H}$ \\
\hline $85-09-23$ & $730.56 \mathrm{M}$ & $90-07-15$ & $730.77 \mathrm{H}$ & $94-04-15$ & $730.54 \mathrm{H}$ \\
\hline $86-08-22$ & $730.58 \mathrm{M}$ & $90-08-15$ & $730.75 \mathrm{H}$ & $94-05-15$ & $730.54 \mathrm{H}$ \\
\hline $86-09-15$ & $730.60 \mathrm{H}$ & $90-09-15$ & $730.74 \mathrm{H}$ & $94-06-02$ & $730.52 \mathrm{M}$ \\
\hline $86-10-15$ & $730.56 \mathrm{H}$ & $90-10-15$ & $730.72 \mathrm{H}$ & $94-07-19$ & $730.50 \mathrm{M}$ \\
\hline $86-11-15$ & $730.55 \mathrm{H}$ & $90-11-15$ & $730.71 \mathrm{H}$ & $94-08-31$ & $730.54 \mathrm{M}$ \\
\hline $86-12-15$ & $730.57 \mathrm{H}$ & $90-12-15$ & $730.77 \mathrm{H}$ & $94-09-27$ & $730.54 \mathrm{M}$ \\
\hline $87-01-15$ & $730.56 \mathrm{H}$ & $91-01-15$ & $730.73 \mathrm{H}$ & $94-12-27$ & $730.56 \mathrm{M}$ \\
\hline $87-02-15$ & $730.58 \mathrm{H}$ & $91-04-15$ & $730.79 \mathrm{H}$ & $95-01-10$ & $730.63 \mathrm{M}$ \\
\hline $87-03-15$ & $730.56 \mathrm{H}$ & $91-05-15$ & $730.78 \mathrm{H}$ & $95-03-02$ & $730.58 \mathrm{M}$ \\
\hline $87-04-15$ & $730.57 \mathrm{H}$ & $91-06-15$ & $730.77 \mathrm{H}$ & $95-03-24$ & $730.59 \mathrm{M}$ \\
\hline $87-05-15$ & $730.59 \mathrm{H}$ & $91-07-15$ & $730.76 \mathrm{H}$ & $95-04-10$ & $730.53 \mathrm{M}$ \\
\hline $87-10-15$ & $730.65 \mathrm{H}$ & $91-08-15$ & $730.79 \mathrm{H}$ & $95-05-04$ & $730.62 \mathrm{M}$ \\
\hline $87-11-15$ & $730.65 \mathrm{H}$ & $91-09-15$ & $730.79 \mathrm{H}$ & $95-06-13$ & $730.51 \mathrm{M}$ \\
\hline $87-12-15$ & $730.67 \mathrm{H}$ & $91-10-15$ & $730.80 \mathrm{H}$ & $95-08-16$ & $730.54 \mathrm{M}$ \\
\hline $88-01-15$ & $730.68 \mathrm{H}$ & $91-11-15$ & $730.80 \mathrm{H}$ & $95-09-06$ & $730.54 \mathrm{M}$ \\
\hline $88-02-15$ & $730.70 \mathrm{H}$ & $91-12-15$ & $730.81 \mathrm{H}$ & $95-12-12$ & $730.62 \mathrm{M}$ \\
\hline $88-03-15$ & $730.72 \mathrm{H}$ & $92-01-15$ & $730.76 \mathrm{H}$ & & \\
\hline $88-04-15$ & $730.74 \mathrm{H}$ & $92-02-15$ & $730.74 \mathrm{H}$ & & \\
\hline $88-05-15$ & $730.74 \mathrm{H}$ & $92-03-15$ & $730.73 \mathrm{H}$ & & \\
\hline $88-06-15$ & $730.73 \mathrm{H}$ & $92-04-15$ & $730.72 \mathrm{H}$ & & \\
\hline $88-07-15$ & $730.70 \mathrm{H}$ & $92-05-15$ & $730.72 \mathrm{H}$ & & \\
\hline $88-08-15$ & $730.70 \mathrm{H}$ & $92-06-15$ & $730.74 \mathrm{H}$ & & \\
\hline $88-09-15$ & $730.71 \mathrm{H}$ & $92-07-15$ & $730.72 \mathrm{H}$ & & \\
\hline $88-10-15$ & $730.73 \mathrm{H}$ & $92-08-15$ & $730.70 \mathrm{H}$ & & \\
\hline $88-11-15$ & $730.75 \mathrm{H}$ & $92-09-15$ & $730.69 \mathrm{H}$ & & \\
\hline $89-02-15$ & $730.69 \mathrm{H}$ & $92-10-15$ & $730.68 \mathrm{H}$ & & \\
\hline $89-03-15$ & $730.67 \mathrm{H}$ & $92-11-15$ & $730.66 \mathrm{H}$ & & \\
\hline $89-04-15$ & $730.70 \mathrm{H}$ & $92-12-15$ & $730.70 \mathrm{H}$ & & \\
\hline $89-05-15$ & $730.74 \mathrm{H}$ & $93-01-15$ & $730.69 \mathrm{H}$ & & \\
\hline $89-06-15$ & $730.76 \mathrm{H}$ & $93-02-15$ & $730.71 \mathrm{H}$ & & \\
\hline $89-07-15$ & $730.75 \mathrm{H}$ & $93-03-15$ & $730.68 \mathrm{H}$ & & \\
\hline $89-08-15$ & $730.76 \mathrm{H}$ & $93-04-15$ & $730.68 \mathrm{H}$ & & \\
\hline $89-09-15$ & $730.76 \mathrm{H}$ & $93-05-15$ & $730.70 \mathrm{H}$ & & \\
\hline $89-10-15$ & $730.77 \mathrm{H}$ & 93-06-15 & $730.70 \mathrm{H}$ & & \\
\hline $89-11-15$ & $730.78 \mathrm{H}$ & $93-07-15$ & $730.69 \mathrm{H}$ & & \\
\hline $89-12-15$ & $730.76 \mathrm{H}$ & $93-08-15$ & $730.69 \mathrm{H}$ & & \\
\hline
\end{tabular}

${ }^{1}$ Actual date of measurement applies to manual measurements only. For monthly mean water levels, the 15 th of each month was used. This was done to facilitate the plotting of the hydrographs for this report. 


\section{Well UE-25 WT\#3}

[M, indicates manual water-level measurement; $\mathrm{H}$, indicates monthly mean water levels averaged from hourly transducer data]

\begin{tabular}{|c|c|c|c|c|c|}
\hline $\begin{array}{c}\text { Date }^{1} \\
\text { (year-month-day) }\end{array}$ & $\begin{array}{c}\text { Water-level } \\
\text { altitude } \\
\text { (meters) }\end{array}$ & $\begin{array}{c}\text { Date }^{1} \\
\text { (year-month-day) }\end{array}$ & $\begin{array}{c}\text { Water-level } \\
\text { altitude } \\
\text { (meters) }\end{array}$ & $\begin{array}{c}\text { Date }^{1} \\
\text { (year-month-day) }\end{array}$ & $\begin{array}{c}\text { Water-level } \\
\text { altitude } \\
\text { (meters) }\end{array}$ \\
\hline $85-01-18$ & $729.55 \mathrm{M}$ & $88-07-15$ & $729.47 \mathrm{H}$ & $92-12-15$ & $729.71 \mathrm{H}$ \\
\hline $85-02-04$ & $729.52 \mathrm{M}$ & $88-08-15$ & $729.46 \mathrm{H}$ & $93-01-15$ & $729.71 \mathrm{H}$ \\
\hline $85-03-15$ & $729.50 \mathrm{H}$ & $88-09-15$ & $729.45 \mathrm{H}$ & $93-02-15$ & $729.74 \mathrm{H}$ \\
\hline $85-04-15$ & $729.57 \mathrm{H}$ & $88-10-15$ & $729.47 \mathrm{H}$ & $93-03-15$ & $729.73 \mathrm{H}$ \\
\hline $85-05-15$ & $729.53 \mathrm{H}$ & $88-11-15$ & $729.65 \mathrm{H}$ & $93-04-15$ & $729.74 \mathrm{H}$ \\
\hline $85-06-15$ & $729.51 \mathrm{H}$ & $88-12-15$ & $729.77 \mathrm{H}$ & $93-05-15$ & $729.74 \mathrm{H}$ \\
\hline $85-07-15$ & $729.49 \mathrm{H}$ & $89-11-14$ & $729.76 \mathrm{M}$ & $93-06-15$ & $729.74 \mathrm{H}$ \\
\hline $85-08-15$ & $729.47 \mathrm{H}$ & $89-12-21$ & $729.70 \mathrm{M}$ & $93-07-15$ & $729.72 \mathrm{H}$ \\
\hline $85-09-15$ & $729.44 \mathrm{H}$ & $90-01-22$ & $729.77 \mathrm{M}$ & $93-08-15$ & $729.71 \mathrm{H}$ \\
\hline $85-10-15$ & $729.46 \mathrm{H}$ & $90-02-16$ & $729.78 \mathrm{M}$ & $93-09-15$ & $729.70 \mathrm{H}$ \\
\hline $85-11-15$ & $729.46 \mathrm{H}$ & $90-03-06$ & $729.78 \mathrm{M}$ & $93-10-15$ & $729.71 \mathrm{H}$ \\
\hline $85-12 \cdot 15$ & $729.41 \mathrm{H}$ & $90-04-10$ & $729.72 \mathrm{M}$ & $93-11-15$ & $729.71 \mathrm{H}$ \\
\hline $86-01-15$ & $729.44 \mathrm{H}$ & $90-05-22$ & $729.78 \mathrm{M}$ & $93-12-15$ & $729.70 \mathrm{H}$ \\
\hline $86-02-15$ & $729.46 \mathrm{H}$ & $90-06-21$ & $729.78 \mathrm{M}$ & $94-01-15$ & $729.71 \mathrm{H}$ \\
\hline $86-03-15$ & $729.50 \mathrm{H}$ & $90-07-23$ & $729.80 \mathrm{M}$ & $94-02-15$ & $729.72 \mathrm{H}$ \\
\hline $86-04-15$ & $729.50 \mathrm{H}$ & $90-08-10$ & $729.75 \mathrm{M}$ & $94-03-15$ & $729.72 \mathrm{H}$ \\
\hline $86-05-15$ & $729.51 \mathrm{H}$ & $90-09-13$ & $729.78 \mathrm{M}$ & $94-04-15$ & $729.72 \mathrm{H}$ \\
\hline $86-06-15$ & $729.50 \mathrm{H}$ & $90-10-22$ & $729.76 \mathrm{M}$ & $94-05-15$ & $729.72 \mathrm{H}$ \\
\hline $86-07-15$ & $729.50 \mathrm{H}$ & $90-11-16$ & $729.76 \mathrm{M}$ & $94-06-15$ & $729.71 \mathrm{H}$ \\
\hline $86-08-15$ & $729.51 \mathrm{H}$ & $90-12-21$ & $729.75 \mathrm{M}$ & $94-07-15$ & $729.70 \mathrm{H}$ \\
\hline $86-09-15$ & $729.52 \mathrm{H}$ & $91-01-24$ & $729.78 \mathrm{M}$ & $94-08-15$ & $729.68 \mathrm{H}$ \\
\hline $86-10-15$ & $729.52 \mathrm{H}$ & $91-02-27$ & $729.85 \mathrm{M}$ & $94-09-15$ & $729.67 \mathrm{H}$ \\
\hline $86-11-15$ & $729.52 \mathrm{H}$ & $91-03-29$ & $729.75 \mathrm{M}$ & $94-10-15$ & $729.66 \mathrm{H}$ \\
\hline $86-12-15$ & $729.53 \mathrm{H}$ & $91-04-25$ & $729.78 \mathrm{M}$ & $94-11-15$ & $729.67 \mathrm{H}$ \\
\hline $87-01-15$ & $729.54 \mathrm{H}$ & $91-05-13$ & $729.81 \mathrm{M}$ & $94-12-15$ & $729.69 \mathrm{H}$ \\
\hline $87-02-15$ & $729.54 \mathrm{H}$ & $91-06-14$ & $729.67 \mathrm{M}$ & $95-01-15$ & $729.70 \mathrm{H}$ \\
\hline $87-03-15$ & $729.53 \mathrm{H}$ & $91-07-24$ & $729.79 \mathrm{M}$ & $95-02-15$ & $729.69 \mathrm{H}$ \\
\hline $87-04-15$ & $729.52 \mathrm{H}$ & $91-08-26$ & $729.78 \mathrm{M}$ & $95-03-15$ & $729.72 \mathrm{H}$ \\
\hline $87-05-15$ & $729.52 \mathrm{H}$ & $91-09-30$ & $729.75 \mathrm{M}$ & $95-04-15$ & $729.74 \mathrm{H}$ \\
\hline $87-06-15$ & $729.50 \mathrm{H}$ & $91-10-29$ & $729.81 \mathrm{M}$ & $95-05-15$ & $729.74 \mathrm{H}$ \\
\hline $87-07-15$ & $729.49 \mathrm{H}$ & $91-11-20$ & $729.71 \mathrm{M}$ & $95-06-15$ & $729.69 \mathrm{H}$ \\
\hline $87-08-15$ & $729.47 \mathrm{H}$ & $91-12-24$ & $729.79 \mathrm{M}$ & $95-07-15$ & $729.70 \mathrm{H}$ \\
\hline $87-09-15$ & $729.46 \mathrm{H}$ & $92-01-28$ & $729.76 \mathrm{M}$ & $95-08-15$ & $729.73 \mathrm{H}$ \\
\hline $87-10-15$ & $729.46 \mathrm{H}$ & $92-02-18$ & $729.75 \mathrm{M}$ & $95-09-15$ & $729.73 \mathrm{H}$ \\
\hline $87-11-15$ & $729.46 \mathrm{H}$ & $92-04-03$ & $729.78 \mathrm{M}$ & $95-12-12$ & $729.76 \mathrm{M}$ \\
\hline $87-12-15$ & $729.46 \mathrm{H}$ & $92-05-15$ & $729.79 \mathrm{H}$ & & \\
\hline $88-01-15$ & $729.46 \mathrm{H}$ & $92-06-15$ & $729.79 \mathrm{H}$ & & \\
\hline $88-02-15$ & $729.46 \mathrm{H}$ & $92-07-15$ & $729.74 \mathrm{H}$ & & \\
\hline $88-03-15$ & $729.48 \mathrm{H}$ & $92-08-15$ & $729.74 \mathrm{H}$ & & \\
\hline $88-04-15$ & $729.48 \mathrm{H}$ & $92-09-15$ & $729.75 \mathrm{H}$ & & \\
\hline $88-05-15$ & $729.48 \mathrm{H}$ & $92-10-15$ & $729.74 \mathrm{H}$ & & \\
\hline $88-06-15$ & $729.49 \mathrm{H}$ & $92-11-15$ & $729.71 \mathrm{H}$ & & \\
\hline
\end{tabular}

${ }^{1}$ Actual date of measurement applies to manual measurements only. For monthly mean water levels, the 15 th of each month was used. This was done to facilitate the plotting of the hydrographs for this report. 


\section{Well UE-25 WT\#4}

$[\mathrm{M}$, indicates manual water-level measurement; $\mathrm{H}$, indicates monthly mean water levels averaged from hourly transducer data]

\begin{tabular}{|c|c|c|c|c|c|}
\hline $\begin{array}{c}\text { Date }^{1} \\
\text { (year-month-day) }\end{array}$ & $\begin{array}{c}\text { Water-level } \\
\text { altitude } \\
\text { (meters) }\end{array}$ & $\begin{array}{c}\text { Date }^{1} \\
\text { (year-month-day) }\end{array}$ & $\begin{array}{c}\text { Water-level } \\
\text { altitude } \\
\text { (meters) }\end{array}$ & $\begin{array}{c}\text { Date }^{1} \\
\text { (year-month-day) }\end{array}$ & $\begin{array}{c}\text { Water-level } \\
\text { altitude } \\
\text { (meters) }\end{array}$ \\
\hline $85-01-21$ & $730.43 \mathrm{M}$ & $88-04-11$ & $730.83 \mathrm{M}$ & $91-12-26$ & $730.88 \mathrm{M}$ \\
\hline $85-01-28$ & $730.47 \mathrm{M}$ & $88-04-18$ & $730.65 \mathrm{M}$ & $92-01-30$ & $730.88 \mathrm{M}$ \\
\hline $85-02-07$ & $730.44 \mathrm{M}$ & 88-04-19 & $730.65 \mathrm{M}$ & $92-02-28$ & $730.89 \mathrm{M}$ \\
\hline 85-02-19 & $730.55 \mathrm{M}$ & $88-05-24$ & $730.66 \mathrm{M}$ & $92-03-26$ & $730.95 \mathrm{M}$ \\
\hline $85-03-20$ & $730.28 \mathrm{M}$ & $88-06-29$ & $730.61 \mathrm{M}$ & $92-04-20$ & $730.87 \mathrm{M}$ \\
\hline $85-03-26$ & $730.39 \mathrm{M}$ & $88-07-14$ & $730.62 \mathrm{M}$ & $92-05-18$ & $730.84 \mathrm{M}$ \\
\hline $85-04-10$ & $730.52 \mathrm{M}$ & $88-09-22$ & $730.61 \mathrm{M}$ & $92-06-25$ & $730.92 \mathrm{M}$ \\
\hline $85-04-29$ & $730.48 \mathrm{M}$ & $88-10-28$ & $730.63 \mathrm{M}$ & $92-07-15$ & $731.17 \mathrm{M}$ \\
\hline $85-06-12$ & $730.67 \mathrm{M}$ & $88-12-20$ & $730.81 \mathrm{M}$ & $92-08-10$ & $730.83 \mathrm{M}$ \\
\hline $85-07-19$ & $730.68 \mathrm{M}$ & 89-01-09 & $730.72 \mathrm{M}$ & $92-09-24$ & $730.89 \mathrm{M}$ \\
\hline $85-08-06$ & $730.71 \mathrm{M}$ & $89-02-22$ & $730.78 \mathrm{M}$ & $92-10-20$ & $730.84 \mathrm{M}$ \\
\hline $85-08-22$ & $730.69 \mathrm{M}$ & $89-03-22$ & $730.87 \mathrm{M}$ & $92-11-24$ & $730.83 \mathrm{M}$ \\
\hline $85-10-03$ & $730.68 \mathrm{M}$ & $89-04-25$ & $730.83 \mathrm{M}$ & $92-12-15$ & $730.92 \mathrm{M}$ \\
\hline $85-12-06$ & $730.72 \mathrm{M}$ & $89-05-24$ & $730.83 \mathrm{M}$ & $93-02-02$ & $730.83 \mathrm{M}$ \\
\hline $86-01-29$ & $730.79 \mathrm{M}$ & $89-06-30$ & $730.85 \mathrm{M}$ & $93-03-03$ & $730.81 \mathrm{M}$ \\
\hline $86-02-12$ & $730.74 \mathrm{M}$ & $89-07-13$ & $730.82 \mathrm{M}$ & $93-03-31$ & $730.81 \mathrm{M}$ \\
\hline 86-03-14 & $730.75 \mathrm{M}$ & $89-07-24$ & $730.84 \mathrm{M}$ & $93-04-28$ & $730.80 \mathrm{M}$ \\
\hline $86-04-11$ & $730.75 \mathrm{M}$ & 89-08-09 & $730.86 \mathrm{M}$ & $93-05-17$ & $730.87 \mathrm{M}$ \\
\hline $86-05-13$ & $730.70 \mathrm{M}$ & $89-10-03$ & $730.88 \mathrm{M}$ & $93-06-28$ & $730.89 \mathrm{M}$ \\
\hline $86-05-27$ & $730.79 \mathrm{M}$ & $89-11-22$ & $730.87 \mathrm{M}$ & $93-11-24$ & $730.77 \mathrm{M}$ \\
\hline $86-08-05$ & $730.79 \mathrm{M}$ & $89-12-08$ & $730.83 \mathrm{M}$ & $93-12-29$ & $730.75 \mathrm{M}$ \\
\hline $86-08-23$ & $730.77 \mathrm{M}$ & $90-01-22$ & $730.87 \mathrm{M}$ & $94-02-03$ & $730.85 \mathrm{M}$ \\
\hline $86-09-14$ & $730.74 \mathrm{M}$ & $90-02-20$ & $730.79 \mathrm{M}$ & $94-03-01$ & $730.71 \mathrm{M}$ \\
\hline $86-10-09$ & $730.74 \mathrm{M}$ & $90-03-12$ & $730.88 \mathrm{M}$ & $94-03-16$ & $730.85 \mathrm{M}$ \\
\hline $86-10-29$ & $730.75 \mathrm{M}$ & $90-04-13$ & $730.89 \mathrm{M}$ & $94-04-14$ & $730.86 \mathrm{M}$ \\
\hline $86-11-14$ & $730.79 \mathrm{M}$ & $90-05-24$ & $730.90 \mathrm{M}$ & $94-05-15$ & $730.81 \mathrm{H}$ \\
\hline $86-12-10$ & $730.72 \mathrm{M}$ & $90-06-18$ & $730.85 \mathrm{M}$ & $94-06-15$ & $730.79 \mathrm{H}$ \\
\hline $86-12-29$ & $730.69 \mathrm{M}$ & $90-07-23$ & $730.88 \mathrm{M}$ & $94-07-15$ & $730.78 \mathrm{H}$ \\
\hline $87-01-10$ & $730.69 \mathrm{M}$ & $90-08-10$ & $730.88 \mathrm{M}$ & $94-08-15$ & $730.78 \mathrm{H}$ \\
\hline $87-01-28$ & $730.81 \mathrm{M}$ & $90-09-27$ & $730.90 \mathrm{M}$ & $94-09-15$ & $730.77 \mathrm{H}$ \\
\hline $87-02-13$ & $730.82 \mathrm{M}$ & $90-10-22$ & $730.88 \mathrm{M}$ & $94-10-15$ & $730.77 \mathrm{H}$ \\
\hline $87-03-11$ & $730.77 \mathrm{M}$ & $90-11-16$ & $730.84 \mathrm{M}$ & $94-11-15$ & $730.75 \mathrm{H}$ \\
\hline $87-04-28$ & $730.81 \mathrm{M}$ & $90-12-21$ & $730.84 \mathrm{M}$ & $94-12-15$ & $730.77 \mathrm{H}$ \\
\hline $87-05-05$ & $730.76 \mathrm{M}$ & $91-01-29$ & $730.88 \mathrm{M}$ & $95-01-15$ & $730.80 \mathrm{H}$ \\
\hline $87-05-28$ & $730.78 \mathrm{M}$ & $91-02-25$ & $730.84 \mathrm{M}$ & $95-02-15$ & $730.80 \mathrm{H}$ \\
\hline $87-06-09$ & $730.78 \mathrm{M}$ & 91-04-01 & $730.89 \mathrm{M}$ & $95-03-15$ & $730.80 \mathrm{H}$ \\
\hline $87-07-13$ & $730.77 \mathrm{M}$ & 91-04-29 & $730.84 \mathrm{M}$ & $95-04-15$ & $730.82 \mathrm{H}$ \\
\hline $87-07-24$ & $730.78 \mathrm{M}$ & 91-05-10 & $730.87 \mathrm{M}$ & $95-05-15$ & $730.82 \mathrm{H}$ \\
\hline $87-08-26$ & $730.74 \mathrm{M}$ & $91-06-12$ & $730.89 \mathrm{M}$ & $95-06-15$ & $730.78 \mathrm{H}$ \\
\hline $87-10-27$ & $730.75 \mathrm{M}$ & $91-07-24$ & $730.90 \mathrm{M}$ & $95-07-15$ & $730.81 \mathrm{H}$ \\
\hline $87-11-30$ & $730.79 \mathrm{M}$ & $91-08-30$ & $730.90 \mathrm{M}$ & $95-08-15$ & $730.81 \mathrm{H}$ \\
\hline $87-12-23$ & $730.85 \mathrm{M}$ & $91-09-24$ & $730.87 \mathrm{M}$ & $95-09-26$ & $730.83 \mathrm{M}$ \\
\hline $88-01-27$ & $730.82 \mathrm{M}$ & $91-10-24$ & $730.93 \mathrm{M}$ & $95-12-05$ & $730.83 \mathrm{M}$ \\
\hline $88-02-17$ & $730.77 \mathrm{M}$ & $91-11-22$ & $730.84 \mathrm{M}$ & & \\
\hline
\end{tabular}

${ }^{1}$ Actual date of measurement applies to manual measurements only. For monthly mean water levels, the 15 th of each month was used. This was done to facilitate the plotting of the hydrographs for this report. 


\section{Well UE-25 WT\#6}

[M, indicates manual water-level measurement; $\mathrm{H}$, indicates monthly mean water levels averaged from hourly transducer data]

\begin{tabular}{|c|c|c|c|c|c|}
\hline $\begin{array}{c}\text { Date }^{1} \\
\text { (year-month-day) }\end{array}$ & $\begin{array}{c}\text { Water-level } \\
\text { altitude } \\
\text { (meters) }\end{array}$ & $\begin{array}{c}\text { Date }^{1} \\
\text { (year-month-day) }\end{array}$ & $\begin{array}{c}\text { Water-level } \\
\text { altltude } \\
\text { (meters) }\end{array}$ & $\begin{array}{c}\text { Date }^{1} \\
\text { (year-month-day) }\end{array}$ & $\begin{array}{c}\text { Water-level } \\
\text { altitude } \\
\text { (meters) }\end{array}$ \\
\hline $85-01-14$ & $1,033.29 \mathrm{M}$ & $89-05-15$ & $1,035.11 \mathrm{H}$ & $92-11-25$ & $1,034.22 \mathrm{M}$ \\
\hline $85-01-30$ & $1,033.49 \mathrm{M}$ & $89-08-15$ & $1,035.26 \mathrm{H}$ & $92-12-08$ & $1,034.34 \mathrm{M}$ \\
\hline $85-02-08$ & $1,033.43 \mathrm{M}$ & $89-09-15$ & $1,035.25 \mathrm{H}$ & $92-12-16$ & $1,034.28 \mathrm{M}$ \\
\hline $85-02-20$ & $1,033.60 \mathrm{M}$ & $89-10-15$ & $1,035.27 \mathrm{H}$ & $93-01-19$ & $1,034.33 \mathrm{M}$ \\
\hline $85-03-04$ & $1,033.46 \mathrm{M}$ & $89-11-15$ & $1,035.35 \mathrm{H}$ & $93-02-12$ & $1,034.31 \mathrm{M}$ \\
\hline $85-03-26$ & $1,033.57 \mathrm{M}$ & $89-12-15$ & $1,035.41 \mathrm{H}$ & $93-03-08$ & $1,034.28 \mathrm{M}$ \\
\hline $85-04-11$ & $1,033.64 \mathrm{M}$ & $90-01-15$ & $1,035.42 \mathrm{H}$ & $93-05-05$ & $1,034.35 \mathrm{M}$ \\
\hline $85-04-29$ & $1,033.67 \mathrm{M}$ & $90-02-15$ & $1,035.38 \mathrm{H}$ & $93-05-24$ & $1,034.39 \mathrm{M}$ \\
\hline $85-06-06$ & $1,033.92 \mathrm{M}$ & $90-03-15$ & $1,035.41 \mathrm{H}$ & $93-06-21$ & $1,034.37 \mathrm{M}$ \\
\hline $85-07-19$ & $1,033.97 \mathrm{M}$ & $90-05-15$ & $1,035.06 \mathrm{H}$ & $93-11-18$ & $1,034.40 \mathrm{M}$ \\
\hline $85-08-08$ & $1,034.01 \mathrm{M}$ & $90-06-15$ & $1,035.12 \mathrm{H}$ & $93-12-22$ & $1,034.39 \mathrm{M}$ \\
\hline $85-10-04$ & $1,034.00 \mathrm{M}$ & $90-07-15$ & $1,035.23 \mathrm{H}$ & $94-01-31$ & $1,034.43 \mathrm{M}$ \\
\hline $85-12-09$ & $1,034.08 \mathrm{M}$ & $90-09-15$ & $1,035.04 \mathrm{H}$ & $94-02-28$ & $1,034.51 \mathrm{M}$ \\
\hline $86-01-28$ & $1,034.09 \mathrm{M}$ & $90-10-15$ & $1,035.04 \mathrm{H}$ & $94-03-28$ & $1,034.48 \mathrm{M}$ \\
\hline $86-02-23$ & $1,034.03 \mathrm{M}$ & $90-11-15$ & $1,035.06 \mathrm{H}$ & $94-04-29$ & $1,034.49 \mathrm{M}$ \\
\hline $86-03-14$ & $1,034.05 \mathrm{M}$ & $91-04-15$ & $1,035.22 \mathrm{H}$ & $94-05-12$ & $1,034.54 \mathrm{M}$ \\
\hline $86-04-21$ & $1,034.03 \mathrm{M}$ & $91-05-15$ & $1,035.22 \mathrm{H}$ & $94-06-07$ & $1,034.50 \mathrm{M}$ \\
\hline $86-05-14$ & $1,034.10 \mathrm{M}$ & $91-06-15$ & $1,035.20 \mathrm{H}$ & $94-07-15$ & $1,034.46 \mathrm{M}$ \\
\hline $86-06-15$ & $1,034.07 \mathrm{M}$ & $91-07-15$ & $1,035.18 \mathrm{H}$ & $94-08-15$ & $1,034.44 \mathrm{M}$ \\
\hline $86-07-21$ & $1,034.12 \mathrm{M}$ & $91-08-15$ & $1,035.14 \mathrm{H}$ & $94-09-28$ & $1,034.43 \mathrm{M}$ \\
\hline $86-08-15$ & $1,034.13 \mathrm{H}$ & $91-09-15$ & $1,035.14 \mathrm{H}$ & $94-10-13$ & $1,034.52 \mathrm{M}$ \\
\hline $86-09-15$ & $1,034.06 \mathrm{H}$ & $91-10-15$ & $1,035.18 \mathrm{H}$ & $94-11-03$ & $1,034.56 \mathrm{M}$ \\
\hline $86-10-15$ & $1,034.04 \mathrm{H}$ & $91-11-15$ & $1,035.13 \mathrm{H}$ & $94-12-13$ & $1,034.47 \mathrm{M}$ \\
\hline $86-11-15$ & $1,034.03 \mathrm{H}$ & $91-12-15$ & $1,035.09 \mathrm{H}$ & $95-01-30$ & $1,034.35 \mathrm{M}$ \\
\hline $86-12-15$ & $1,034.02 \mathrm{H}$ & $92-01-15$ & $1,035.04 \mathrm{H}$ & $95-02-23$ & $1,034.42 \mathrm{M}$ \\
\hline $87-01-15$ & $1,033.89 \mathrm{H}$ & $92-02-15$ & $1,035.05 \mathrm{H}$ & $95-03-22$ & $1,034.42 \mathrm{M}$ \\
\hline $87-02-15$ & $1,033.89 \mathrm{H}$ & $92-03-11$ & $1,034.95 \mathrm{M}$ & $95-04-13$ & $1,034.48 \mathrm{M}$ \\
\hline $87-03-15$ & $1,033.90 \mathrm{H}$ & $92-04-03$ & $1,035.04 \mathrm{M}$ & $95-05-09$ & $1,034.45 \mathrm{M}$ \\
\hline $87-10-15$ & $1,034.82 \mathrm{H}$ & $92-04-10$ & $1,035.03 \mathrm{M}$ & $95-06-20$ & $1,034.59 \mathrm{M}$ \\
\hline $87-11-15$ & $1,034.78 \mathrm{H}$ & $92-04-17$ & $1,035.03 \mathrm{M}$ & $95-07-24$ & $1,034.54 \mathrm{M}$ \\
\hline $88-03-15$ & $1,035.03 \mathrm{H}$ & $92-05-18$ & $1,035.00 \mathrm{M}$ & $95-08-01$ & $1,034.54 \mathrm{M}$ \\
\hline $88-04-15$ & $1,035.03 \mathrm{H}$ & $92-06-04$ & $1,035.07 \mathrm{M}$ & $95-09-05$ & $1,034.54 \mathrm{M}$ \\
\hline $88-05-15$ & $1,035.12 \mathrm{H}$ & $92-06-23$ & $1,035.02 \mathrm{M}$ & $95-12-04$ & $1,034.52 \mathrm{M}$ \\
\hline $88-06-15$ & $1,035.06 \mathrm{H}$ & $92-07-17$ & $1,036.09 \mathrm{M}$ & & \\
\hline $88-07-15$ & $1,035.15 \mathrm{H}$ & $92-07-28$ & $1,035.86 \mathrm{M}$ & & \\
\hline $88-08-15$ & $1,035.21 \mathrm{H}$ & $92-08-18$ & $1,034.89 \mathrm{M}$ & & \\
\hline $88-09-15$ & $1,035.25 \mathrm{H}$ & $92-08-31$ & $1,034.59 \mathrm{M}$ & & \\
\hline $88-10-15$ & $1,035.01 \mathrm{H}$ & $92-09-22$ & $1,034.33 \mathrm{M}$ & & \\
\hline $88-11-15$ & $1,035.00 \mathrm{H}$ & $92-09-29$ & $1,034.29 \mathrm{M}$ & & \\
\hline $89-02-15$ & $1,035.03 \mathrm{H}$ & $92-10-16$ & $1,034.26 \mathrm{M}$ & & \\
\hline $89-03-15$ & $1,035.06 \mathrm{H}$ & $92-10-30$ & $1,034.35 \mathrm{M}$ & & \\
\hline $89-04-15$ & $1,035.06 \mathrm{H}$ & $92-11-13$ & $1,034.24 \mathrm{M}$ & & \\
\hline
\end{tabular}

${ }^{1}$ Actual date of measurement applies to manual measurements only. For monthly mean water levels, the 15 th of each month was used. This was done to facilitate the plotting of the hydrographs for this report. 


\section{Well USW WT-7}

[M, indicates manual water-level measurement; $\mathrm{H}$, indicates monthly mean water levels averaged from hourly transducer data]

\begin{tabular}{|c|c|c|c|c|c|}
\hline $\begin{array}{c}\text { Date }^{1} \\
\text { (year-month-day) }\end{array}$ & $\begin{array}{c}\text { Water-level } \\
\text { altitude } \\
\text { (meters) }\end{array}$ & $\begin{array}{c}\text { Date }^{1} \\
\text { (year-month-day) }\end{array}$ & $\begin{array}{c}\text { Water-level } \\
\text { altitude } \\
\text { (meters) }\end{array}$ & $\begin{array}{c}\text { Date }^{1} \\
\text { (year-month-day) }\end{array}$ & $\begin{array}{l}\text { Water-level } \\
\text { altitude } \\
\text { (meters) }\end{array}$ \\
\hline $85-01-03$ & $775.65 \mathrm{M}$ & 89-01-19 & $775.87 \mathrm{M}$ & $92-11-02$ & $775.91 \mathrm{M}$ \\
\hline $85-01-17$ & $775.58 \mathrm{M}$ & $89-02-16$ & $775.79 \mathrm{M}$ & $92-12-01$ & $775.93 \mathrm{M}$ \\
\hline $85-02-01$ & $775.62 \mathrm{M}$ & $89-03-23$ & $775.90 \mathrm{M}$ & 93-04-09 & $775.91 \mathrm{M}$ \\
\hline $85-02-06$ & $775.62 \mathrm{M}$ & $89-04-21$ & $775.87 \mathrm{M}$ & $93-05-28$ & $775.90 \mathrm{M}$ \\
\hline $85-02-21$ & $775.60 \mathrm{M}$ & $89-05-18$ & $775.86 \mathrm{M}$ & $93-06-14$ & $775.90 \mathrm{M}$ \\
\hline $85-03-18$ & $775.47 \mathrm{M}$ & $89-07-18$ & $775.84 \mathrm{M}$ & $93-07-16$ & $775.90 \mathrm{M}$ \\
\hline $85-04-16$ & $775.71 \mathrm{M}$ & $89-10-04$ & $775.84 \mathrm{M}$ & 93-11-09 & $775.85 \mathrm{M}$ \\
\hline $85-06-21$ & $775.79 \mathrm{M}$ & $89-11-28$ & $775.71 \mathrm{M}$ & $93-12-23$ & $775.81 \mathrm{M}$ \\
\hline $85-07-17$ & $775.80 \mathrm{M}$ & $89-12-21$ & $775.81 \mathrm{M}$ & $94-02-01$ & $775.86 \mathrm{M}$ \\
\hline $85-08-07$ & $775.78 \mathrm{M}$ & $90-01-30$ & $775.99 \mathrm{M}$ & $94-02-25$ & $775.91 \mathrm{M}$ \\
\hline $85-08-21$ & $775.77 \mathrm{M}$ & $90-02-28$ & $775.85 \mathrm{M}$ & $94-03-29$ & $775.88 \mathrm{M}$ \\
\hline $85-09-30$ & $775.81 \mathrm{M}$ & $90-03-16$ & $775.81 \mathrm{M}$ & $94-04-22$ & $775.90 \mathrm{M}$ \\
\hline $85-10-16$ & $775.85 \mathrm{M}$ & $90-04-18$ & $775.86 \mathrm{M}$ & $94-05-24$ & $775.88 \mathrm{M}$ \\
\hline $85-10-31$ & $775.87 \mathrm{M}$ & $90-05-25$ & $775.84 \mathrm{M}$ & $94-06-08$ & $775.84 \mathrm{M}$ \\
\hline $85-11-29$ & $775.84 \mathrm{M}$ & $90-06-15$ & $775.87 \mathrm{M}$ & $94-07-18$ & $775.87 \mathrm{M}$ \\
\hline $85-12-13$ & $775.87 \mathrm{M}$ & $90-07-02$ & $775.90 \mathrm{M}$ & $94-08-25$ & $775.88 \mathrm{M}$ \\
\hline $86-01-22$ & $775.80 \mathrm{M}$ & $90-08-17$ & $775.87 \mathrm{M}$ & $94-09-22$ & $775.90 \mathrm{M}$ \\
\hline $86-02-25$ & $775.78 \mathrm{M}$ & $90-09-26$ & $775.88 \mathrm{M}$ & $94-10-26$ & $775.88 \mathrm{M}$ \\
\hline 86-03-19 & $775.65 \mathrm{M}$ & $90-10-03$ & $775.82 \mathrm{M}$ & $94-11-22$ & $775.80 \mathrm{M}$ \\
\hline $86-04-29$ & $775.77 \mathrm{M}$ & $90-11-21$ & $775.80 \mathrm{M}$ & $94-12-22$ & $775.94 \mathrm{M}$ \\
\hline 86-07-02 & $775.74 \mathrm{M}$ & $90-12-31$ & $775.80 \mathrm{M}$ & $95-01-17$ & $775.87 \mathrm{M}$ \\
\hline 86-08-04 & $775.76 \mathrm{M}$ & $91-01-30$ & $775.81 \mathrm{M}$ & $95-02-21$ & $775.94 \mathrm{M}$ \\
\hline 86-09-04 & $775.78 \mathrm{M}$ & $91-02-21$ & $775.91 \mathrm{M}$ & $95-03-28$ & $775.98 \mathrm{M}$ \\
\hline $86-09-30$ & $775.80 \mathrm{M}$ & $91-03-28$ & $775.78 \mathrm{M}$ & $95-04-19$ & $775.94 \mathrm{M}$ \\
\hline $86-10-31$ & $775.82 \mathrm{M}$ & $91-04-26$ & $775.82 \mathrm{M}$ & $95-05-17$ & $775.95 \mathrm{M}$ \\
\hline $86-11-20$ & $775.79 \mathrm{M}$ & $91-05-21$ & $775.91 \mathrm{M}$ & $95-06-22$ & $775.88 \mathrm{M}$ \\
\hline $86-12-05$ & $775.87 \mathrm{M}$ & $91-06-20$ & $775.87 \mathrm{M}$ & $95-07-19$ & $775.94 \mathrm{M}$ \\
\hline 87-01-14 & $775.88 \mathrm{M}$ & $91-07-29$ & $775.89 \mathrm{M}$ & $95-08-29$ & $775.94 \mathrm{M}$ \\
\hline $87-02-05$ & $775.71 \mathrm{M}$ & $91-08-29$ & $775.84 \mathrm{M}$ & $95-12-06$ & $775.95 \mathrm{M}$ \\
\hline 87-03-05 & $775.82 \mathrm{M}$ & $91-09-27$ & $775.92 \mathrm{M}$ & & \\
\hline $87-05-14$ & $775.81 \mathrm{M}$ & $91-10-28$ & $775.84 \mathrm{M}$ & & \\
\hline $87-05-27$ & $775.78 \mathrm{M}$ & $91-11-25$ & $775.90 \mathrm{M}$ & & \\
\hline $88-05-16$ & $775.72 \mathrm{M}$ & $91-12-30$ & $775.90 \mathrm{M}$ & & \\
\hline $88-06-03$ & $775.67 \mathrm{M}$ & $92-01-27$ & $775.86 \mathrm{M}$ & & \\
\hline $88-06-13$ & $775.62 \mathrm{M}$ & $92-02-24$ & $775.86 \mathrm{M}$ & & \\
\hline $88-06-23$ & $775.66 \mathrm{M}$ & $92-03-24$ & $775.84 \mathrm{M}$ & & \\
\hline $88-07-08$ & $775.57 \mathrm{M}$ & $92-04-23$ & $775.83 \mathrm{M}$ & & \\
\hline $88-08-17$ & $775.69 \mathrm{M}$ & $92-05-08$ & $775.91 \mathrm{M}$ & & \\
\hline $88-09-08$ & $775.73 \mathrm{M}$ & $92-06-05$ & $775.97 \mathrm{M}$ & & \\
\hline $88-10-06$ & $775.70 \mathrm{M}$ & $92-07-13$ & $775.87 \mathrm{M}$ & & \\
\hline $88-11-17$ & $775.73 \mathrm{M}$ & $92-08-12$ & $775.93 \mathrm{M}$ & & \\
\hline $88-12-21$ & $775.88 \mathrm{M}$ & $92-09-08$ & $775.91 \mathrm{M}$ & & \\
\hline
\end{tabular}

${ }^{1}$ Actual date of measurement applies to manual measurements only. For monthly mean water levels, the 15 th of each month was used. This was done to facilitate the plotting of the hydrographs for this report. 
Well USW WT-10

[M. indicates manual water-level measurement; $\mathrm{H}$, indicates monthly mean water levels averaged from hourly transducer data]

\begin{tabular}{|c|c|c|c|c|c|}
\hline $\begin{array}{c}\text { Date }^{1} \\
\text { (year-month-day) }\end{array}$ & $\begin{array}{c}\text { Water-level } \\
\text { altitude } \\
\text { (meters) }\end{array}$ & $\begin{array}{c}\text { Date }^{1} \\
\text { (year-month-day) }\end{array}$ & $\begin{array}{c}\text { Water-level } \\
\text { altitude } \\
\text { (meters) }\end{array}$ & $\begin{array}{c}\text { Date }^{1} \\
\text { (year-month-day) }\end{array}$ & $\begin{array}{l}\text { Water-level } \\
\text { altitude } \\
\text { (meters) }\end{array}$ \\
\hline $85-01-03$ & $775.81 \mathrm{M}$ & $88-04-05$ & $775.63 \mathrm{M}$ & $92-02-24$ & $776.00 \mathrm{M}$ \\
\hline $85-01-17$ & $775.83 \mathrm{M}$ & 88-05-09 & $775.63 \mathrm{M}$ & $92-03-24$ & $775.96 \mathrm{M}$ \\
\hline $85-02-01$ & $775.85 \mathrm{M}$ & $88-05-17$ & $776.04 \mathrm{M}$ & $92-04-23$ & $775.98 \mathrm{M}$ \\
\hline $85-02-06$ & $775.56 \mathrm{M}$ & $88-05-18$ & $775.99 \mathrm{M}$ & $92-05-08$ & $776.08 \mathrm{M}$ \\
\hline $85-02-21$ & $775.83 \mathrm{M}$ & $88-06-23$ & $775.99 \mathrm{M}$ & $92-06-05$ & $776.14 \mathrm{M}$ \\
\hline $85-03-18$ & $775.71 \mathrm{M}$ & 88-07-08 & $775.99 \mathrm{M}$ & $92-07-13$ & $776.02 \mathrm{M}$ \\
\hline $85-04-16$ & $775.89 \mathrm{M}$ & $88-08-17$ & $775.79 \mathrm{M}$ & $92-08-12$ & $776.04 \mathrm{M}$ \\
\hline $85-06-21$ & $775.94 \mathrm{M}$ & 88-09-08 & $775.85 \mathrm{M}$ & $92-09-08$ & $776.05 \mathrm{M}$ \\
\hline $85-07-17$ & $775.94 \mathrm{M}$ & $88-10-06$ & $776.01 \mathrm{M}$ & $92-11-02$ & $776.05 \mathrm{M}$ \\
\hline $85-08-07$ & $775.91 \mathrm{M}$ & $88-11-17$ & $776.06 \mathrm{M}$ & $92-12-01$ & $776.10 \mathrm{M}$ \\
\hline $85-08-21$ & $775.90 \mathrm{M}$ & $88-12-21$ & $776.03 \mathrm{M}$ & $93-01-25$ & $776.08 \mathrm{M}$ \\
\hline $85-09-18$ & $776.01 \mathrm{M}$ & 89-01-19 & $776.00 \mathrm{M}$ & $93-02-18$ & $776.13 \mathrm{M}$ \\
\hline $85-09-30$ & $775.94 \mathrm{M}$ & $89-02-16$ & $775.95 \mathrm{M}$ & $93-03-26$ & $776.16 \mathrm{M}$ \\
\hline $85-10-16$ & $775.98 \mathrm{M}$ & $89-03-23$ & $776.03 \mathrm{M}$ & $93-04-22$ & $776.21 \mathrm{M}$ \\
\hline $85-10-31$ & $775.98 \mathrm{M}$ & $89-04-21$ & $776.03 \mathrm{M}$ & $93-05-28$ & $776.09 \mathrm{M}$ \\
\hline $85-11-29$ & $776.04 \mathrm{M}$ & $89-05-18$ & $775.99 \mathrm{M}$ & $93-06-14$ & $776.12 \mathrm{M}$ \\
\hline $85-12-13$ & $776.15 \mathrm{M}$ & $89-07-18$ & $775.99 \mathrm{M}$ & $93-07-16$ & $776.08 \mathrm{M}$ \\
\hline $86-01-22$ & $775.91 \mathrm{M}$ & $89-10-04$ & $775.97 \mathrm{M}$ & $93-11-09$ & $776.06 \mathrm{M}$ \\
\hline 86-03-19 & $775.84 \mathrm{M}$ & $89-11-28$ & $775.88 \mathrm{M}$ & $93-12-23$ & $776.02 \mathrm{M}$ \\
\hline $86-04-29$ & $775.97 \mathrm{M}$ & $89-12-21$ & $775.96 \mathrm{M}$ & $94-02-01$ & $776.02 \mathrm{M}$ \\
\hline $86-06-04$ & $775.95 \mathrm{M}$ & $90-01-30$ & $776.13 \mathrm{M}$ & $94-02-25$ & $776.10 \mathrm{M}$ \\
\hline $86-07-02$ & $775.91 \mathrm{M}$ & $90-02-28$ & $775.96 \mathrm{M}$ & $94-03-29$ & $776.07 \mathrm{M}$ \\
\hline $86-08-04$ & $775.93 \mathrm{M}$ & $90-03-16$ & $775.95 \mathrm{M}$ & $94-04-22$ & $776.14 \mathrm{M}$ \\
\hline $86-09-04$ & $775.92 \mathrm{M}$ & $90-04-18$ & $776.00 \mathrm{M}$ & $94-05-24$ & $776.09 \mathrm{M}$ \\
\hline $86-09-30$ & $775.95 \mathrm{M}$ & $90-05-25$ & $776.00 \mathrm{M}$ & $94-06-08$ & $776.16 \mathrm{M}$ \\
\hline $86-10-31$ & $775.97 \mathrm{M}$ & $90-06-15$ & $776.01 \mathrm{M}$ & $94-06-16$ & $776.07 \mathrm{M}$ \\
\hline $86-11-20$ & $775.93 \mathrm{M}$ & $90-07-02$ & $776.05 \mathrm{M}$ & $94-07-15$ & $776.08 \mathrm{H}$ \\
\hline $86-12-05$ & $776.00 \mathrm{M}$ & $90-08-17$ & $776.02 \mathrm{M}$ & $94-08-15$ & $776.10 \mathrm{H}$ \\
\hline $87-01-14$ & $776.00 \mathrm{M}$ & $90-09-26$ & $776.04 \mathrm{M}$ & $94-09-15$ & $776.17 \mathrm{H}$ \\
\hline $87-02-05$ & $775.85 \mathrm{M}$ & $90-10-03$ & $775.98 \mathrm{M}$ & $94-10-15$ & $776.20 \mathrm{H}$ \\
\hline $87-03-05$ & $775.98 \mathrm{M}$ & $90-11-21$ & $775.94 \mathrm{M}$ & $94-11-15$ & $776.21 \mathrm{H}$ \\
\hline $87-05-14$ & $775.63 \mathrm{M}$ & $90-12-31$ & $775.92 \mathrm{M}$ & $94-12-15$ & $776.21 \mathrm{H}$ \\
\hline $87-05-27$ & $775.95 \mathrm{M}$ & $91-01-30$ & $775.94 \mathrm{M}$ & $95-01-15$ & $776.17 \mathrm{H}$ \\
\hline $87-06-17$ & $775.98 \mathrm{M}$ & $91-02-21$ & $776.03 \mathrm{M}$ & $95-02-15$ & $776.15 \mathrm{H}$ \\
\hline $87-07-14$ & $775.96 \mathrm{M}$ & $91-03-28$ & $775.91 \mathrm{M}$ & $95-03-15$ & $776.11 \mathrm{H}$ \\
\hline $87-08-06$ & $775.97 \mathrm{M}$ & $91-04-26$ & $775.98 \mathrm{M}$ & $95-04-15$ & $776.12 \mathrm{H}$ \\
\hline $87-08-27$ & $775.94 \mathrm{M}$ & $91-05-21$ & $776.05 \mathrm{M}$ & $95-05-15$ & $776.13 \mathrm{H}$ \\
\hline $87-09-17$ & $775.95 \mathrm{M}$ & $91-06-20$ & $776.02 \mathrm{M}$ & $95-06-15$ & $776.12 \mathrm{H}$ \\
\hline $87-10-21$ & $775.97 \mathrm{M}$ & $91-07-29$ & $776.04 \mathrm{M}$ & $95-07-15$ & $776.10 \mathrm{H}$ \\
\hline $87-11-08$ & $775.90 \mathrm{M}$ & $91-08-29$ & $776.00 \mathrm{M}$ & $95-08-15$ & $776.10 \mathrm{H}$ \\
\hline $87-12-03$ & $775.95 \mathrm{M}$ & $91-09-27$ & $776.06 \mathrm{M}$ & $95-09-05$ & $776.05 \mathrm{M}$ \\
\hline $87-12-16$ & $776.05 \mathrm{M}$ & $91-10-28$ & $775.94 \mathrm{M}$ & $95-12-06$ & $775.97 \mathrm{M}$ \\
\hline $88-01-22$ & $775.89 \mathrm{M}$ & $91-11-25$ & $776.05 \mathrm{M}$ & & \\
\hline $88-02-24$ & $776.00 \mathrm{M}$ & $91-12-30$ & $776.04 \mathrm{M}$ & & \\
\hline 88-03-07 & $775.96 \mathrm{M}$ & $92-01-27$ & $776.00 \mathrm{M}$ & & \\
\hline
\end{tabular}

${ }^{1}$ Actual date of measurement applies to manual measurements only. For monthly mean water levels, the 15 th of each month was used. This was done to facilitate the plotting of the hydrographs for this report. 
Well USW WT-11

[M, indicates manual water-level measurement; $H$, indicates monthly mean water levels averaged from hourly transducer data]

\begin{tabular}{|c|c|c|c|c|c|}
\hline $\begin{array}{c}\text { Date }^{1} \\
\text { (year-month-day) }\end{array}$ & $\begin{array}{c}\text { Water-level } \\
\text { altitude } \\
\text { (meters) }\end{array}$ & $\begin{array}{c}\text { Date }^{1} \\
\text { (year-month-day) }\end{array}$ & $\begin{array}{c}\text { Water-level } \\
\text { altitude } \\
\text { (meters) }\end{array}$ & $\begin{array}{c}\text { Date }^{1} \\
\text { (year-month-day) }\end{array}$ & $\begin{array}{c}\text { Water-level } \\
\text { altitude } \\
\text { (meters) }\end{array}$ \\
\hline $85-01-03$ & $730.34 \mathrm{M}$ & $88-11-15$ & $730.81 \mathrm{H}$ & $92-10-15$ & $730.59 \mathrm{H}$ \\
\hline $85-01-17$ & $730.47 \mathrm{M}$ & $89-03-15$ & $730.69 \mathrm{H}$ & $92-11-15$ & $730.57 \mathrm{H}$ \\
\hline $85-02-01$ & $730.23 \mathrm{M}$ & $89-04-15$ & $730.73 \mathrm{H}$ & $92-12-15$ & $730.59 \mathrm{H}$ \\
\hline $85-02-06$ & $730.21 \mathrm{M}$ & $89-05-15$ & $730.72 \mathrm{H}$ & $93-01-15$ & $730.59 \mathrm{H}$ \\
\hline $85-02-21$ & $730.45 \mathrm{M}$ & $89-06-15$ & $730.72 \mathrm{H}$ & $93-02-15$ & $730.61 \mathrm{H}$ \\
\hline $85-03-18$ & $730.28 \mathrm{M}$ & $89-07-15$ & $730.71 \mathrm{H}$ & $93-03-15$ & $730.62 \mathrm{H}$ \\
\hline $85-04-16$ & $730.51 \mathrm{M}$ & $89-08-15$ & $730.73 \mathrm{H}$ & $93-04-15$ & $730.69 \mathrm{H}$ \\
\hline $85-06-21$ & $730.59 \mathrm{M}$ & $89-09-15$ & $730.71 \mathrm{H}$ & 93-05-15 & $730.72 \mathrm{H}$ \\
\hline $85-07-17$ & $730.58 \mathrm{M}$ & $89-10-15$ & $730.70 \mathrm{H}$ & $93-06-15$ & $730.73 \mathrm{H}$ \\
\hline $85-09-03$ & $730.62 \mathrm{M}$ & $89-11-15$ & $730.69 \mathrm{H}$ & $93-07-15$ & $730.71 \mathrm{H}$ \\
\hline $85-09-18$ & $730.66 \mathrm{M}$ & $89-12-15$ & $730.69 \mathrm{H}$ & $93-08-15$ & $730.71 \mathrm{H}$ \\
\hline $85-09-30$ & $730.58 \mathrm{M}$ & $90-01-15$ & $730.68 \mathrm{H}$ & $93-09-15$ & $730.69 \mathrm{H}$ \\
\hline $85-10-16$ & $730.66 \mathrm{M}$ & $90-02-15$ & $730.69 \mathrm{H}$ & $93-10-15$ & $730.70 \mathrm{H}$ \\
\hline $85-10-31$ & $730.66 \mathrm{M}$ & $90-03-15$ & $730.72 \mathrm{H}$ & $93-11-15$ & $730.70 \mathrm{H}$ \\
\hline $85-11-29$ & $730.68 \mathrm{M}$ & $90-04-15$ & $730.73 \mathrm{H}$ & $93-12-15$ & $730.70 \mathrm{H}$ \\
\hline $85-12-13$ & $730.54 \mathrm{M}$ & $90-05-15$ & $730.74 \mathrm{H}$ & $94-01-15$ & $730.71 \mathrm{H}$ \\
\hline $86-01-22$ & $730.60 \mathrm{M}$ & $90-06-15$ & $730.72 \mathrm{H}$ & $94-02-15$ & $730.71 \mathrm{H}$ \\
\hline $86-03-19$ & $730.53 \mathrm{M}$ & $90-07-15$ & $730.71 \mathrm{H}$ & $94-03-15$ & $730.69 \mathrm{H}$ \\
\hline $86-04-29$ & $730.66 \mathrm{M}$ & $90-08-15$ & $730.71 \mathrm{H}$ & $94-04-15$ & $730.67 \mathrm{H}$ \\
\hline $86-06-04$ & $730.66 \mathrm{M}$ & $90-09-15$ & $730.71 \mathrm{H}$ & $94-05-15$ & $730.64 \mathrm{H}$ \\
\hline $86-07-02$ & $730.59 \mathrm{M}$ & $90-12-15$ & $730.71 \mathrm{H}$ & $94-06-15$ & $730.62 \mathrm{H}$ \\
\hline 86-08-04 & $730.61 \mathrm{M}$ & $91-01-15$ & $730.69 \mathrm{H}$ & $94-07-29$ & $730.68 \mathrm{M}$ \\
\hline 86-09-04 & $730.61 \mathrm{M}$ & $91-02-15$ & $730.70 \mathrm{H}$ & $94-08-25$ & $730.73 \mathrm{M}$ \\
\hline $86-09-30$ & $730.59 \mathrm{M}$ & $91-03-15$ & $730.72 \mathrm{H}$ & $94-09-22$ & $730.63 \mathrm{M}$ \\
\hline $86-10-15$ & $730.56 \mathrm{M}$ & $91-04-15$ & $730.70 \mathrm{H}$ & $94-10-26$ & $730.67 \mathrm{M}$ \\
\hline $86-11-15$ & $730.57 \mathrm{H}$ & $91-05-15$ & $730.71 \mathrm{H}$ & $94-11-22$ & $730.56 \mathrm{M}$ \\
\hline $86-12-15$ & $730.60 \mathrm{H}$ & $91-06-15$ & $730.70 \mathrm{H}$ & $94-12-22$ & $730.65 \mathrm{M}$ \\
\hline $87-01-15$ & $730.65 \mathrm{H}$ & $91-07-15$ & $730.69 \mathrm{H}$ & $95-01-17$ & $730.74 \mathrm{M}$ \\
\hline $87-02-15$ & $730.71 \mathrm{H}$ & $91-08-15$ & $730.71 \mathrm{H}$ & $95-02-21$ & $730.67 \mathrm{M}$ \\
\hline $87-03-15$ & $730.73 \mathrm{H}$ & $91-09-15$ & $730.71 \mathrm{H}$ & $95-04-05$ & $730.69 \mathrm{M}$ \\
\hline $87-04-15$ & $730.77 \mathrm{H}$ & $91-10-15$ & $730.72 \mathrm{H}$ & $95-04-19$ & $730.76 \mathrm{M}$ \\
\hline $87-05-15$ & $730.75 \mathrm{H}$ & $91-11-15$ & $730.71 \mathrm{H}$ & $95-05-17$ & $730.66 \mathrm{M}$ \\
\hline $88-01-15$ & $730.62 \mathrm{H}$ & $91-12-15$ & $730.71 \mathrm{H}$ & $95-06-22$ & $730.62 \mathrm{M}$ \\
\hline $88-02-15$ & $730.65 \mathrm{H}$ & $92-01-15$ & $730.71 \mathrm{H}$ & $95-08-29$ & $730.67 \mathrm{M}$ \\
\hline $88-03-15$ & $730.69 \mathrm{H}$ & $92-02-15$ & $730.73 \mathrm{H}$ & $95-12-06$ & $730.68 \mathrm{M}$ \\
\hline $88-04-15$ & $730.74 \mathrm{H}$ & $92-03-15$ & $730.74 \mathrm{H}$ & & \\
\hline $88-05-15$ & $730.74 \mathrm{H}$ & $92-04-15$ & $730.72 \mathrm{H}$ & & \\
\hline $88-06-15$ & $730.71 \mathrm{H}$ & $92-05-15$ & $730.72 \mathrm{H}$ & & \\
\hline $88-07-15$ & $730.76 \mathrm{H}$ & $92-06-15$ & $730.72 \mathrm{H}$ & & \\
\hline $88-08-15$ & $730.75 \mathrm{H}$ & $92-07-15$ & $730.67 \mathrm{H}$ & & \\
\hline $88-09-15$ & $730.77 \mathrm{H}$ & $92-08-15$ & $730.64 \mathrm{H}$ & & \\
\hline $88-10-15$ & $730.81 \mathrm{H}$ & $92-09-15$ & $730.62 \mathrm{H}$ & & \\
\hline
\end{tabular}

${ }^{1}$ Actual date of measurement applies to manual measurements only. For monthly mean water levels, the 15 th of each month was used. This was done to facilitate the plotting of the hydrographs for this report. 


\section{Well UE-25 WT\#12}

[M, indicates manual water-level measurement; $\mathrm{H}$, indicates monthly mean water levels averaged from hourly transducer data]

\begin{tabular}{|c|c|c|c|c|c|}
\hline $\begin{array}{c}\text { Date }^{1} \\
\text { (year-month-day) }\end{array}$ & $\begin{array}{l}\text { Water-level } \\
\text { altitude } \\
\text { (meters) }\end{array}$ & $\begin{array}{c}\text { Date }^{t} \\
\text { (year-month-day) }\end{array}$ & $\begin{array}{c}\text { Water-level } \\
\text { altitude } \\
\text { (meters) }\end{array}$ & $\begin{array}{c}\text { Date }^{1} \\
\text { (year-month-day) }\end{array}$ & $\begin{array}{l}\text { Water-level } \\
\text { altitude } \\
\text { (meters) }\end{array}$ \\
\hline $85-01-03$ & $729.28 \mathrm{M}$ & $88-05-25$ & $729.51 \mathrm{M}$ & $92-03-27$ & $729.58 \mathrm{M}$ \\
\hline $85-01-17$ & $729.27 \mathrm{M}$ & $88-06-27$ & $729.52 \mathrm{M}$ & $92-05-07$ & $729.51 \mathrm{M}$ \\
\hline $85-01-28$ & $729.30 \mathrm{M}$ & $88-07-15$ & $729.53 \mathrm{M}$ & $92-05-20$ & $729.54 \mathrm{M}$ \\
\hline $85-02-11$ & $729.20 \mathrm{M}$ & $88-08-12$ & $729.57 \mathrm{M}$ & $92-06-25$ & $729.54 \mathrm{M}$ \\
\hline $85-02-25$ & $729.30 \mathrm{M}$ & $88-09-23$ & $729.51 \mathrm{M}$ & $92-07-16$ & $729.50 \mathrm{M}$ \\
\hline $85-03-05$ & $729.11 \mathrm{M}$ & $88-10-27$ & $729.55 \mathrm{M}$ & $92-08-19$ & $729.46 \mathrm{M}$ \\
\hline $85-03-28$ & $729.29 \mathrm{M}$ & $88-12-23$ & $729.48 \mathrm{M}$ & $92-09-28$ & $729.45 \mathrm{M}$ \\
\hline $85-04-10$ & $729.38 \mathrm{M}$ & $89-01-09$ & $729.47 \mathrm{M}$ & $92-10-29$ & $729.50 \mathrm{M}$ \\
\hline $85-07-16$ & $729.43 \mathrm{M}$ & $89-02-22$ & $729.47 \mathrm{M}$ & $92-11-30$ & $729.39 \mathrm{M}$ \\
\hline $85-08-08$ & $729.45 \mathrm{M}$ & $89-03-13$ & $729.53 \mathrm{M}$ & $92-12-17$ & $729.51 \mathrm{M}$ \\
\hline $85-09-17$ & $729.49 \mathrm{M}$ & $89-04-26$ & $729.48 \mathrm{M}$ & $93-02-02$ & $729.43 \mathrm{M}$ \\
\hline $85-12-06$ & $729.44 \mathrm{M}$ & $89-05-30$ & $729.49 \mathrm{M}$ & $93-03-04$ & $729.38 \mathrm{M}$ \\
\hline $86-01-29$ & $729.48 \mathrm{M}$ & $89-07-21$ & $729.52 \mathrm{M}$ & $93-03-30$ & $729.40 \mathrm{M}$ \\
\hline $86-02-20$ & $729.42 \mathrm{M}$ & $89-08-11$ & $729.49 \mathrm{M}$ & $93-04-29$ & $729.43 \mathrm{M}$ \\
\hline $86-03-20$ & $729.40 \mathrm{M}$ & $89-10-05$ & $729.48 \mathrm{M}$ & $93-06-02$ & $729.46 \mathrm{M}$ \\
\hline $86-04-23$ & $729.48 \mathrm{M}$ & $89-11-21$ & $729.53 \mathrm{M}$ & $93-06-29$ & $729.45 \mathrm{M}$ \\
\hline $86-05-16$ & $729.42 \mathrm{M}$ & $89-12-20$ & $729.47 \mathrm{M}$ & $93-12-01$ & $729.39 \mathrm{M}$ \\
\hline $86-05-23$ & $729.48 \mathrm{M}$ & $90-01-23$ & $729.52 \mathrm{M}$ & $93-12-30$ & $729,43 \mathrm{M}$ \\
\hline $86-06-10$ & $729.42 \mathrm{M}$ & $90-02-08$ & $729.50 \mathrm{M}$ & $94-02-02$ & $729.50 \mathrm{M}$ \\
\hline $86-08-11$ & $729.45 \mathrm{M}$ & 90-03-09 & $729.54 \mathrm{M}$ & 94-03-01 & $729.37 \mathrm{M}$ \\
\hline $86-08-21$ & $729.46 \mathrm{M}$ & $90-04-17$ & $729.51 \mathrm{M}$ & $94-03-24$ & $729.45 \mathrm{M}$ \\
\hline $86-09-12$ & $729.47 \mathrm{M}$ & $90-05-23$ & $729.57 \mathrm{M}$ & $94-05-02$ & $729.45 \mathrm{M}$ \\
\hline $86-09-26$ & $729.42 \mathrm{M}$ & $90-06-20$ & $729.51 \mathrm{M}$ & $94-05-27$ & $729.42 \mathrm{M}$ \\
\hline $86-10-29$ & $729.47 \mathrm{M}$ & $90-07-11$ & $729.51 \mathrm{M}$ & $94-06-24$ & $729.43 \mathrm{M}$ \\
\hline $86-11-21$ & $729.51 \mathrm{M}$ & $90-08-20$ & $729.51 \mathrm{M}$ & $94-07-27$ & $729.43 \mathrm{M}$ \\
\hline $86-12-30$ & $729.47 \mathrm{M}$ & $90-09-28$ & $729.52 \mathrm{M}$ & $94-08-31$ & $729.43 \mathrm{M}$ \\
\hline $87-01-13$ & $729.52 \mathrm{M}$ & $90-10-29$ & $729.51 \mathrm{M}$ & $94-09-30$ & $729.48 \mathrm{M}$ \\
\hline $87-01-26$ & $729.46 \mathrm{M}$ & $90-11-30$ & $729.54 \mathrm{M}$ & $94-10-27$ & $729.41 \mathrm{M}$ \\
\hline $87-03-13$ & $729.53 \mathrm{M}$ & $91-01-24$ & $729.52 \mathrm{M}$ & $94-11-29$ & $729.40 \mathrm{M}$ \\
\hline $87-05-01$ & $729.51 \mathrm{M}$ & $91-02-25$ & $729.47 \mathrm{M}$ & $94-12-29$ & $729.44 \mathrm{M}$ \\
\hline $87-05-28$ & $729.48 \mathrm{M}$ & $91-03-27$ & $729.52 \mathrm{M}$ & $95-01-30$ & $729.39 \mathrm{M}$ \\
\hline $87-06-12$ & $729.46 \mathrm{M}$ & $91-04-30$ & $729.51 \mathrm{M}$ & $95-02-24$ & $729.41 \mathrm{M}$ \\
\hline $87-07-06$ & $729.50 \mathrm{M}$ & $91-05-14$ & $729.56 \mathrm{M}$ & $95-03-23$ & $729.51 \mathrm{M}$ \\
\hline $87-07-28$ & $729.51 \mathrm{M}$ & $91-06-11$ & $729.51 \mathrm{M}$ & $95-04-24$ & $729.48 \mathrm{M}$ \\
\hline $87-08-26$ & $729.47 \mathrm{M}$ & $91-07-25$ & $729.54 \mathrm{M}$ & $95-05-22$ & $729.48 \mathrm{M}$ \\
\hline $87-11-30$ & $729.48 \mathrm{M}$ & $91-08-27$ & $729.55 \mathrm{M}$ & $95-06-21$ & $729.39 \mathrm{M}$ \\
\hline $87-12-28$ & $729.53 \mathrm{M}$ & $91-09-25$ & $729.52 \mathrm{M}$ & $95-08-17$ & $729.39 \mathrm{M}$ \\
\hline $88-01-28$ & $729.52 \mathrm{M}$ & $91-10-25$ & $729.53 \mathrm{M}$ & $95-09-19$ & $729.51 \mathrm{M}$ \\
\hline $88-02-26$ & $729.53 \mathrm{M}$ & $91-11-21$ & $729.57 \mathrm{M}$ & $95-12-13$ & $729.42 \mathrm{M}$ \\
\hline $88-04-25$ & $729.51 \mathrm{M}$ & $91-12-31$ & $729.54 \mathrm{M}$ & & \\
\hline $88-05-02$ & $729.45 \mathrm{M}$ & $92-01-31$ & $729.54 \mathrm{M}$ & & \\
\hline $88-05-03$ & $729.55 \mathrm{M}$ & $92-02-21$ & $729.49 \mathrm{M}$ & & \\
\hline
\end{tabular}

${ }^{1}$ Actual date of measurement applies to manual measurements only. For monthly mean water levels, the 15 th of each month was used. This was done to facilitate the plotting of the hydrographs for this report. 


\section{Well UE-25 WT\#13}

[M, indicates manual water-level measurement; $\mathrm{H}$, indicates monthly mean water levels averaged from hourly transducer data]

\begin{tabular}{|c|c|c|c|c|c|}
\hline $\begin{array}{c}\text { Date }^{1} \\
\text { (year-month-day) }\end{array}$ & $\begin{array}{l}\text { Water-level } \\
\text { altitude } \\
\text { (meters) }\end{array}$ & $\begin{array}{c}\text { Date }^{1} \\
\text { (year-month-day) }\end{array}$ & $\begin{array}{c}\text { Water-level } \\
\text { altitude } \\
\text { (meters) }\end{array}$ & $\begin{array}{c}\text { Date }^{1} \\
\text { (year-month-day) }\end{array}$ & $\begin{array}{l}\text { Water-level } \\
\text { altitude } \\
\text { (meters) }\end{array}$ \\
\hline $85-01-14$ & $728.90 \mathrm{M}$ & $88-07-15$ & $729.29 \mathrm{H}$ & $92-12-15$ & $729.19 \mathrm{H}$ \\
\hline $85-01-30$ & $728.92 \mathrm{M}$ & $88-08-15$ & $728.95 \mathrm{H}$ & $93-01-15$ & $729.17 \mathrm{H}$ \\
\hline $85-02-04$ & $728.90 \mathrm{M}$ & $88-09-15$ & $728.91 \mathrm{H}$ & $93-02-15$ & $729.19 \mathrm{H}$ \\
\hline $85-02-11$ & $728.83 \mathrm{M}$ & $88-10-15$ & $728.53 \mathrm{H}$ & $93-03-15$ & $729.14 \mathrm{H}$ \\
\hline $85-02-12$ & $728.86 \mathrm{M}$ & $88-11-15$ & $728.80 \mathrm{H}$ & $93-04-15$ & $729.11 \mathrm{H}$ \\
\hline $85-03-15$ & $728.84 \mathrm{H}$ & $88-12-15$ & $728.87 \mathrm{H}$ & $93-05-15$ & $729.06 \mathrm{H}$ \\
\hline $85-04-15$ & $728.95 \mathrm{H}$ & $89-01-15$ & $728.93 \mathrm{H}$ & $93-06-15$ & $729.06 \mathrm{H}$ \\
\hline $85-05-15$ & $729.22 \mathrm{H}$ & $89-02-15$ & $728.98 \mathrm{H}$ & $93-07-15$ & $729.06 \mathrm{H}$ \\
\hline $85-06-15$ & $729.34 \mathrm{H}$ & $89-03-15$ & $728.86 \mathrm{H}$ & $93-08-15$ & $729.08 \mathrm{H}$ \\
\hline $85-07-15$ & $729.43 \mathrm{H}$ & $89-04-15$ & $728.77 \mathrm{H}$ & $93-09-15$ & $729.09 \mathrm{H}$ \\
\hline $85-08-15$ & $729.28 \mathrm{H}$ & $89-06-15$ & $729.22 \mathrm{H}$ & $93-10-15$ & $729.14 \mathrm{H}$ \\
\hline $85-09-15$ & $729.08 \mathrm{H}$ & $89-11-15$ & $729.16 \mathrm{H}$ & $93-11-15$ & $729.13 \mathrm{H}$ \\
\hline $85-10-15$ & $729.06 \mathrm{H}$ & $89-12-15$ & $729.17 \mathrm{H}$ & $93-12-15$ & $729.12 \mathrm{H}$ \\
\hline $85-11-15$ & $729.10 \mathrm{H}$ & $90-01-15$ & $729.19 \mathrm{H}$ & $94-01-15$ & $729.15 \mathrm{H}$ \\
\hline $85-12-15$ & $729.02 \mathrm{H}$ & $90-02-15$ & $729.18 \mathrm{H}$ & $94-02-15$ & $729.19 \mathrm{H}$ \\
\hline $86-01-15$ & $729.05 \mathrm{H}$ & $90-03-15$ & $729.15 \mathrm{H}$ & $94-03-15$ & $729.17 \mathrm{H}$ \\
\hline $86-02-15$ & $729.13 \mathrm{H}$ & $90-04-15$ & $729.17 \mathrm{H}$ & $94-04-15$ & $729.18 \mathrm{H}$ \\
\hline $86-03-15$ & $729.17 \mathrm{H}$ & $90-05-15$ & $729.18 \mathrm{H}$ & $94-05-15$ & $729.17 \mathrm{H}$ \\
\hline $86-04-15$ & $729.19 \mathrm{H}$ & $90-06-15$ & $729.16 \mathrm{H}$ & $94-06-15$ & $729.17 \mathrm{H}$ \\
\hline $86-07-15$ & $729.07 \mathrm{H}$ & $90-07-15$ & $729.20 \mathrm{H}$ & $94-07-15$ & $729.13 \mathrm{M}$ \\
\hline $86-08-15$ & $729.09 \mathrm{H}$ & $90-08-15$ & $729.15 \mathrm{H}$ & $94-08-15$ & $729.15 \mathrm{M}$ \\
\hline $86-09-15$ & $729.11 \mathrm{H}$ & $90-09-15$ & $729.16 \mathrm{H}$ & $94-09-28$ & $729.12 \mathrm{M}$ \\
\hline $86-10-15$ & $729.09 \mathrm{H}$ & $90-10-15$ & $729.18 \mathrm{H}$ & $94-10-13$ & $729.26 \mathrm{M}$ \\
\hline $86-11-15$ & $729.10 \mathrm{H}$ & $90-11-15$ & $729.17 \mathrm{H}$ & $94-11-03$ & $729.17 \mathrm{M}$ \\
\hline $86-12-15$ & $729.13 \mathrm{H}$ & $90-12-15$ & $729.16 \mathrm{H}$ & $94-12-29$ & $729.17 \mathrm{M}$ \\
\hline $87-01-15$ & $729.16 \mathrm{H}$ & $91-01-15$ & $729.17 \mathrm{H}$ & $95-01-26$ & $729.13 \mathrm{M}$ \\
\hline $87-02-15$ & $729.19 \mathrm{H}$ & $91-08-15$ & $729.15 \mathrm{H}$ & $95-03-03$ & $729.15 \mathrm{M}$ \\
\hline $87-03-15$ & $729.12 \mathrm{H}$ & $91-09-15$ & $729.14 \mathrm{H}$ & $95-03-22$ & $729.19 \mathrm{M}$ \\
\hline $87-04-15$ & $729.14 \mathrm{H}$ & $91-10-15$ & $729.14 \mathrm{H}$ & $95-04-13$ & $729.21 \mathrm{M}$ \\
\hline $87-05-15$ & $729.13 \mathrm{H}$ & $91-11-15$ & $729.12 \mathrm{H}$ & $95-05-10$ & $729.14 \mathrm{M}$ \\
\hline $87-06-15$ & $729.12 \mathrm{H}$ & $91-12-15$ & $729.13 \mathrm{H}$ & $95-06-20$ & $729.21 \mathrm{M}$ \\
\hline $87-07-15$ & $729.13 \mathrm{H}$ & $92-01-15$ & $729.13 \mathrm{H}$ & $95-07-24$ & $729.23 \mathrm{M}$ \\
\hline $87-08-15$ & $729.11 \mathrm{H}$ & $92-02-15$ & $729.15 \mathrm{H}$ & $95-08-30$ & $729.19 \mathrm{M}$ \\
\hline $87-09-15$ & $729.12 \mathrm{H}$ & $92-03-15$ & $729.16 \mathrm{H}$ & $95-12-04$ & $729.13 \mathrm{M}$ \\
\hline $87-11-15$ & $729.13 \mathrm{H}$ & $92-04-15$ & $729.09 \mathrm{H}$ & & \\
\hline $87-12-15$ & $729.11 \mathrm{H}$ & $92-05-15$ & $729.09 \mathrm{H}$ & & \\
\hline $88-01-15$ & $729.13 \mathrm{H}$ & $92-06-15$ & $729.10 \mathrm{H}$ & & \\
\hline $88-02-15$ & $729.14 \mathrm{H}$ & $92-07-15$ & $729.10 \mathrm{H}$ & & \\
\hline $88-03-15$ & $729.08 \mathrm{H}$ & $92-08-15$ & $729.14 \mathrm{H}$ & & \\
\hline $88-04-15$ & $729.03 \mathrm{H}$ & $92-09-15$ & $729.15 \mathrm{H}$ & & \\
\hline $88-05-15$ & $728.99 \mathrm{H}$ & $92-10-15$ & $729.16 \mathrm{H}$ & & \\
\hline 88-06-15 & $729.14 \mathrm{H}$ & $92-11-15$ & $729.16 \mathrm{H}$ & & \\
\hline
\end{tabular}

${ }^{1}$ Actual date of measurement applies to manual measurements only. For monthly mean water levels, the 15 th of each month was used. This was done to facilitate the plotting of the hydrographs for this report. 


\section{Well UE-25 WT\#14}

$[M$, indicates manual water-level measurement; $\mathrm{H}$, indicates monthly mean water levels averaged from hourly transducer data]

\begin{tabular}{|c|c|c|c|c|c|}
\hline $\begin{array}{c}\text { Date }^{1} \\
\text { (year-month-day) }\end{array}$ & $\begin{array}{c}\text { Water-level } \\
\text { altitude } \\
\text { (meters) }\end{array}$ & $\begin{array}{c}\text { Date }^{1} \\
\text { (year-month-day) }\end{array}$ & $\begin{array}{c}\text { Water-level } \\
\text { altitude } \\
\text { (meters) }\end{array}$ & $\begin{array}{c}\text { Date }^{\top} \\
\text { (year-month-day) }\end{array}$ & $\begin{array}{c}\text { Water-level } \\
\text { altitude } \\
\text { (meters) }\end{array}$ \\
\hline $85-01-15$ & $729.52 \mathrm{M}$ & $88-03-18$ & $729.67 \mathrm{M}$ & $91-11-22$ & $729.70 \mathrm{M}$ \\
\hline $85-01-30$ & $729.43 \mathrm{M}$ & $88-03-21$ & $729.72 \mathrm{M}$ & $91-12-26$ & $729.71 \mathrm{M}$ \\
\hline $85-02-08$ & $729.51 \mathrm{M}$ & $88-03-31$ & $729.69 \mathrm{M}$ & $92-01-30$ & $729.72 \mathrm{M}$ \\
\hline 85-02-19 & $729.63 \mathrm{M}$ & 88-04-01 & $729.69 \mathrm{M}$ & $92-02-28$ & $729.72 \mathrm{M}$ \\
\hline $85-03-20$ & $729.29 \mathrm{M}$ & $88-04-19$ & $729.73 \mathrm{M}$ & $92-03-26$ & $729.78 \mathrm{M}$ \\
\hline $85-03-25$ & $729.53 \mathrm{M}$ & $88-05-26$ & $729.70 \mathrm{M}$ & $92-04-20$ & $729.71 \mathrm{M}$ \\
\hline $85-04-10$ & $729.57 \mathrm{M}$ & $88-06-28$ & $729.72 \mathrm{M}$ & $92-05-19$ & $729.74 \mathrm{M}$ \\
\hline $85-04-29$ & $729.49 \mathrm{M}$ & $88-07-11$ & $729.72 \mathrm{M}$ & $92-06-25$ & $729.75 \mathrm{M}$ \\
\hline $85-06-11$ & $729.60 \mathrm{M}$ & $88-08-10$ & $729.74 \mathrm{M}$ & $92-07-15$ & $729.70 \mathrm{M}$ \\
\hline $85-07-19$ & $729.59 \mathrm{M}$ & $88-09-14$ & $729.71 \mathrm{M}$ & $92-08-18$ & $729.69 \mathrm{M}$ \\
\hline 85-08-09 & $729.60 \mathrm{M}$ & $88-10-28$ & $729.70 \mathrm{M}$ & $92-09-24$ & $729.74 \mathrm{M}$ \\
\hline $85-08-22$ & $729.61 \mathrm{M}$ & $88-12-20$ & $729.70 \mathrm{M}$ & $92-10-16$ & $729.66 \mathrm{M}$ \\
\hline $85-10-03$ & $729.60 \mathrm{M}$ & 89-01-09 & $729.68 \mathrm{M}$ & $92-11-23$ & $729.71 \mathrm{M}$ \\
\hline $85-12-06$ & $729.62 \mathrm{M}$ & $89-02-27$ & $729.75 \mathrm{M}$ & $92-12-08$ & $729.67 \mathrm{M}$ \\
\hline $86-01-28$ & $729.69 \mathrm{M}$ & $89-03-14$ & $729.73 \mathrm{M}$ & $93-02-01$ & $729.69 \mathrm{M}$ \\
\hline $86-02-20$ & $729.63 \mathrm{M}$ & $89-04-25$ & $729.71 \mathrm{M}$ & $93-03-01$ & $729.64 \mathrm{M}$ \\
\hline $86-03-14$ & $729.66 \mathrm{M}$ & $89-05-24$ & $729.72 \mathrm{M}$ & $93-03-29$ & $729.67 \mathrm{M}$ \\
\hline $86-04-11$ & $729.69 \mathrm{M}$ & $89-06-30$ & $729.72 \mathrm{M}$ & $93-04-21$ & $729.68 \mathrm{M}$ \\
\hline $86-05-13$ & $729.67 \mathrm{M}$ & $89-07-19$ & $729.72 \mathrm{M}$ & $93-06-01$ & $729.68 \mathrm{M}$ \\
\hline $86-06-12$ & $729.69 \mathrm{M}$ & $89-08-14$ & $729.72 \mathrm{M}$ & $93-06-21$ & $729.68 \mathrm{M}$ \\
\hline $86-07-08$ & $729.68 \mathrm{M}$ & $89-10-03$ & $729.73 \mathrm{M}$ & $93-11-19$ & $729.61 \mathrm{M}$ \\
\hline $86-07-16$ & $729.68 \mathrm{M}$ & $89-11-16$ & $729.75 \mathrm{M}$ & $93-12-13$ & $729.64 \mathrm{M}$ \\
\hline $86-08-14$ & $729.69 \mathrm{M}$ & $89-12-11$ & $729.67 \mathrm{M}$ & $94-02-03$ & $729.68 \mathrm{M}$ \\
\hline $86-08-23$ & $729.69 \mathrm{M}$ & $90-01-25$ & $729.68 \mathrm{M}$ & $94-02-28$ & $729.61 \mathrm{M}$ \\
\hline $86-09-14$ & $729.66 \mathrm{M}$ & $90-02-20$ & $729.68 \mathrm{M}$ & $94-03-15$ & $729.68 \mathrm{M}$ \\
\hline $86-10-10$ & $729.71 \mathrm{M}$ & 90-03-09 & $729.77 \mathrm{M}$ & $94-04-15$ & $729.60 \mathrm{M}$ \\
\hline $86-10-30$ & $729.69 \mathrm{M}$ & $90-04-13$ & $729.72 \mathrm{M}$ & $94-05-26$ & $729.67 \mathrm{M}$ \\
\hline $86-11-24$ & $729.69 \mathrm{M}$ & $90-05-24$ & $729.72 \mathrm{M}$ & $94-06-07$ & $729.64 \mathrm{M}$ \\
\hline $86-12-10$ & $729.66 \mathrm{M}$ & $90-06-18$ & $729.70 \mathrm{M}$ & $94-06-22$ & $729.63 \mathrm{M}$ \\
\hline $86-12-30$ & $729.66 \mathrm{M}$ & $90-07-23$ & $729.72 \mathrm{M}$ & $94-07-15$ & $729.62 \mathrm{H}$ \\
\hline $87-01-10$ & $729.64 \mathrm{M}$ & $90-08-15$ & $729.74 \mathrm{M}$ & $94-08-15$ & $729.62 \mathrm{H}$ \\
\hline $87-01-28$ & $729.73 \mathrm{M}$ & $90-09-27$ & $729.74 \mathrm{M}$ & $94-09-15$ & $729.61 \mathrm{H}$ \\
\hline $87-02-13$ & $729.73 \mathrm{M}$ & $90-10-22$ & $729.73 \mathrm{M}$ & $94-10-15$ & $729.61 \mathrm{H}$ \\
\hline $87-03-11$ & $729.66 \mathrm{M}$ & $90-11-16$ & $729.71 \mathrm{M}$ & $94-11-15$ & $729.60 \mathrm{H}$ \\
\hline 87-04-08 & $729.69 \mathrm{M}$ & $90-12-21$ & $729.72 \mathrm{M}$ & $94-12-15$ & $729.60 \mathrm{H}$ \\
\hline $87-05-05$ & $729.98 \mathrm{M}$ & $91-01-28$ & $729.79 \mathrm{M}$ & $95-01-15$ & $729.61 \mathrm{H}$ \\
\hline $87-05-29$ & $729.68 \mathrm{M}$ & $91-02-28$ & $729.86 \mathrm{M}$ & $95-02-15$ & $729.63 \mathrm{H}$ \\
\hline $87-06-09$ & $729.72 \mathrm{M}$ & $91-03-27$ & $729.73 \mathrm{M}$ & $95-03-15$ & $729.65 \mathrm{H}$ \\
\hline $87-07-13$ & $729.68 \mathrm{M}$ & $91-04-29$ & $729.74 \mathrm{M}$ & $95-04-15$ & $729.67 \mathrm{H}$ \\
\hline $87-07-24$ & $729.69 \mathrm{M}$ & $91-05-07$ & $729.74 \mathrm{M}$ & $95-05-15$ & $729.68 \mathrm{H}$ \\
\hline $87-08-26$ & $729.68 \mathrm{M}$ & $91-06-13$ & $729.74 \mathrm{M}$ & $95-06-15$ & $729.64 \mathrm{H}$ \\
\hline $87-10-27$ & $729.68 \mathrm{M}$ & $91-07-23$ & $729.73 \mathrm{M}$ & $95-07-15$ & $729.65 \mathrm{H}$ \\
\hline $87-12-28$ & $729.70 \mathrm{M}$ & $91-08-30$ & $729.71 \mathrm{M}$ & $95-08-15$ & $729.67 \mathrm{H}$ \\
\hline $88-01-26$ & $729.69 \mathrm{M}$ & $91-09-16$ & $729.71 \mathrm{M}$ & $95-09-15$ & $729.66 \mathrm{H}$ \\
\hline $88-02-16$ & $729.73 \mathrm{M}$ & $91-10-24$ & $729.75 \mathrm{M}$ & $95-12-04$ & $729.63 \mathrm{M}$ \\
\hline
\end{tabular}

${ }^{1}$ Actual date of measurement applies to manual measurements only. For monthly mean water levels, the 15 th of each month was used. This was done to facilitate the plotting of the hydrographs for this report. 


\section{Well UE-25 WT\#15}

[M, indicates manual water-level measurement; $\mathrm{H}$, indicates monthly mean water levels averaged from hourly transcucer data]

\begin{tabular}{|c|c|c|c|c|c|}
\hline $\begin{array}{c}\text { Date }^{1} \\
\text { (year-month-day) }\end{array}$ & $\begin{array}{c}\text { Water-level } \\
\text { altitude } \\
\text { (meters) }\end{array}$ & $\begin{array}{c}\text { Date }^{1} \\
\text { (year-month-day) }\end{array}$ & $\begin{array}{l}\text { Water-level } \\
\text { altitude } \\
\text { (meters) }\end{array}$ & $\begin{array}{c}\text { Date }^{1} \\
\text { (year-month-day) }\end{array}$ & $\begin{array}{l}\text { Water-level } \\
\text { altitude } \\
\text { (meters) }\end{array}$ \\
\hline $85-01-14$ & $728.99 \mathrm{M}$ & $88-04-25$ & $729.18 \mathrm{M}$ & $91-11-26$ & $729.22 \mathrm{M}$ \\
\hline $85-01-30$ & $729.01 \mathrm{M}$ & $88-04-26$ & $729.21 \mathrm{M}$ & $91-12-26$ & $729.22 \mathrm{M}$ \\
\hline $85-02-08$ & $729.07 \mathrm{M}$ & $88-05-26$ & $729.24 \mathrm{M}$ & $92-01-30$ & $729.19 \mathrm{M}$ \\
\hline $85-02-20$ & $729.15 \mathrm{M}$ & $88-06-30$ & $729.24 \mathrm{M}$ & $92-02-28$ & $729.18 \mathrm{M}$ \\
\hline 85-03-04 & $729.02 \mathrm{M}$ & $88-07-14$ & $729.24 \mathrm{M}$ & $92-04-03$ & $729.22 \mathrm{M}$ \\
\hline $85-03-26$ & $729.02 \mathrm{M}$ & $88-08-19$ & $729.28 \mathrm{M}$ & $92-04-20$ & $729.19 \mathrm{M}$ \\
\hline $85-04-11$ & $729.00 \mathrm{M}$ & $88-09-14$ & $729.21 \mathrm{M}$ & $92-05-18$ & $729.22 \mathrm{M}$ \\
\hline $85-04-29$ & $728.98 \mathrm{M}$ & $88-10-28$ & $729.25 \mathrm{M}$ & $92-06-25$ & $729.21 \mathrm{M}$ \\
\hline $85-06-11$ & $729.13 \mathrm{M}$ & $88-12-20$ & $729.26 \mathrm{M}$ & $92-07-15$ & $729.21 \mathrm{M}$ \\
\hline $85-07-23$ & $729.18 \mathrm{M}$ & 89-01-09 & $729.17 \mathrm{M}$ & $92-08-18$ & $729.27 \mathrm{M}$ \\
\hline $85-08-09$ & $729.16 \mathrm{M}$ & $89-02-23$ & $729.26 \mathrm{M}$ & $92-09-22$ & $729.23 \mathrm{M}$ \\
\hline $85-12-30$ & $729.23 \mathrm{M}$ & 89-03-13 & $729.29 \mathrm{M}$ & $92-10-16$ & $729.24 \mathrm{M}$ \\
\hline $86-01-28$ & $729.25 \mathrm{M}$ & $89-04-26$ & $729.28 \mathrm{M}$ & $92-11-25$ & $729.24 \mathrm{M}$ \\
\hline $86-02-13$ & $729.19 \mathrm{M}$ & $89-05-30$ & $729.22 \mathrm{M}$ & $92-12-08$ & $729.28 \mathrm{M}$ \\
\hline $86-03-24$ & $729.20 \mathrm{M}$ & $89-06-30$ & $729.23 \mathrm{M}$ & $93-02-01$ & $729.24 \mathrm{M}$ \\
\hline $86-04-11$ & $729.19 \mathrm{M}$ & $89-07-24$ & $729.23 \mathrm{M}$ & 93-03-01 & $729.20 \mathrm{M}$ \\
\hline $86-05-15$ & $729.25 \mathrm{M}$ & 89-08-14 & $729.27 \mathrm{M}$ & $93-03-29$ & $729.30 \mathrm{M}$ \\
\hline $86-06-12$ & $729.22 \mathrm{M}$ & $89-10-03$ & $729.28 \mathrm{M}$ & $93-05-05$ & $729.30 \mathrm{M}$ \\
\hline $86-07-08$ & $729.23 \mathrm{M}$ & $89-11-16$ & $729.27 \mathrm{M}$ & $93-05-24$ & $729.26 \mathrm{M}$ \\
\hline 86-08-05 & $729.25 \mathrm{M}$ & $89-12-11$ & $729.19 \mathrm{M}$ & $93-06-21$ & $729.24 \mathrm{M}$ \\
\hline $86-08-23$ & $729.26 \mathrm{M}$ & $90-01-23$ & $729.27 \mathrm{M}$ & $93-11-18$ & $729.18 \mathrm{M}$ \\
\hline $86-09-14$ & $729.22 \mathrm{M}$ & $90-02-20$ & $729.19 \mathrm{M}$ & $93-12-22$ & $729.04 \mathrm{M}$ \\
\hline $86-10-14$ & $729.19 \mathrm{M}$ & $90-03-12$ & $729.27 \mathrm{M}$ & $94-01-31$ & $729.12 \mathrm{M}$ \\
\hline $86-10-30$ & $729.23 \mathrm{M}$ & $90-04-16$ & $729.34 \mathrm{M}$ & $94-02-28$ & $729.15 \mathrm{M}$ \\
\hline $86-11-29$ & $729.27 \mathrm{M}$ & $90-05-30$ & $729.27 \mathrm{M}$ & $94-03-28$ & $729.17 \mathrm{M}$ \\
\hline 86-12-11 & $729.26 \mathrm{M}$ & $90-06-18$ & $729.21 \mathrm{M}$ & $94-04-29$ & $729.17 \mathrm{M}$ \\
\hline $86-12-30$ & $729.22 \mathrm{M}$ & $90-07-23$ & $729.26 \mathrm{M}$ & $94-05-26$ & $729.21 \mathrm{M}$ \\
\hline $87-01-10$ & $729.16 \mathrm{M}$ & $90-08-15$ & $729.31 \mathrm{M}$ & $94-06-07$ & $729.20 \mathrm{M}$ \\
\hline $87-01-28$ & $729.20 \mathrm{M}$ & $90-09-21$ & $729.19 \mathrm{M}$ & $94-07-15$ & $729.17 \mathrm{M}$ \\
\hline $87-02-13$ & $729.21 \mathrm{M}$ & $90-10-22$ & $729.22 \mathrm{M}$ & $94-08-15$ & $729.18 \mathrm{M}$ \\
\hline $87-03-12$ & $729.20 \mathrm{M}$ & $90-11-16$ & $729.21 \mathrm{M}$ & $94-09-28$ & $729.17 \mathrm{M}$ \\
\hline $87-04-28$ & $729.24 \mathrm{M}$ & $90-12-21$ & $729.20 \mathrm{M}$ & $94-10-13$ & $729.28 \mathrm{M}$ \\
\hline $87-05-05$ & $729.24 \mathrm{M}$ & $91-01-28$ & $729.32 \mathrm{M}$ & $94-11-03$ & $729.21 \mathrm{M}$ \\
\hline $87-05-29$ & $729.23 \mathrm{M}$ & $91-02-28$ & $729.42 \mathrm{M}$ & $94-12-13$ & $729.21 \mathrm{M}$ \\
\hline $87-06-10$ & $729.23 \mathrm{M}$ & $91-04-02$ & $729.16 \mathrm{M}$ & $95-01-11$ & $729.24 \mathrm{M}$ \\
\hline $87-07-22$ & $729.21 \mathrm{M}$ & $91-04-25$ & $729.29 \mathrm{M}$ & $95-04-27$ & $729.34 \mathrm{M}$ \\
\hline $87-08-26$ & $729.21 \mathrm{M}$ & $91-05-07$ & $729.22 \mathrm{M}$ & $95-05-09$ & $729.22 \mathrm{M}$ \\
\hline $87-10-27$ & $729.25 \mathrm{M}$ & $91-06-13$ & $729.25 \mathrm{M}$ & $95-06-20$ & $729.30 \mathrm{M}$ \\
\hline $87-12-28$ & $729.20 \mathrm{M}$ & $91-07-23$ & $729.23 \mathrm{M}$ & $95-08-29$ & $729.32 \mathrm{M}$ \\
\hline $88-01-27$ & $729.23 \mathrm{M}$ & $91-08-27$ & $729.30 \mathrm{M}$ & $95-12-04$ & $729.18 \mathrm{M}$ \\
\hline $88-02-16$ & $729.24 \mathrm{M}$ & $91-09-16$ & $729.19 \mathrm{M}$ & & \\
\hline 88-04-18 & $729.24 \mathrm{M}$ & $91-10-25$ & $729.27 \mathrm{M}$ & & \\
\hline
\end{tabular}

${ }^{1}$ Actual date of measurement applies to manual measurements only. For monthly mean water levels, the 15 th of each month was used. This was done to facilitate the plotting of the hydrographs for this report. 


\section{Well UE-25 WT\#16}

[M, indicates manual water-level measurement; $\mathrm{H}$, indicates monthly mean water levels averaged from hourly transducer data]

\begin{tabular}{|c|c|c|c|c|c|}
\hline $\begin{array}{c}\text { Date }^{1} \\
\text { (year-month-day) }\end{array}$ & $\begin{array}{l}\text { Water-level } \\
\text { altitude } \\
\text { (meters) }\end{array}$ & $\begin{array}{c}\text { Date }^{1} \\
\text { (year-month-day) }\end{array}$ & $\begin{array}{c}\text { Water-level } \\
\text { altitude } \\
\text { (meters) }\end{array}$ & $\begin{array}{c}\text { Date }^{1} \\
\text { (year-month-day) }\end{array}$ & $\begin{array}{c}\text { Water-level } \\
\text { altitude } \\
\text { (meters) }\end{array}$ \\
\hline $85-01-14$ & $737.82 \mathrm{M}$ & $88-11-15$ & $738.10 \mathrm{H}$ & $92-10-30$ & $738.31 \mathrm{M}$ \\
\hline $85-01-30$ & $737.83 \mathrm{M}$ & $89-02-15$ & $738.36 \mathrm{H}$ & $92-11-13$ & $738.18 \mathrm{M}$ \\
\hline $85-02-08$ & $737.89 \mathrm{M}$ & $89-03-15$ & $738.38 \mathrm{H}$ & $92-11-25$ & $738.18 \mathrm{M}$ \\
\hline $85-02-20$ & $737.92 \mathrm{M}$ & $89-04-15$ & $738.38 \mathrm{H}$ & $92-12-08$ & $738.28 \mathrm{M}$ \\
\hline $85-03-04$ & $737.89 \mathrm{M}$ & $89-05-15$ & $738.38 \mathrm{H}$ & $92-12-16$ & $738.25 \mathrm{M}$ \\
\hline $85-03-26$ & $737.91 \mathrm{M}$ & $89-06-15$ & $738.38 \mathrm{H}$ & $93-01-19$ & $738.40 \mathrm{M}$ \\
\hline $85-04-11$ & $737.88 \mathrm{M}$ & $89-07-15$ & $738.36 \mathrm{H}$ & $93-02-12$ & $738.53 \mathrm{M}$ \\
\hline $85-06-11$ & $738.10 \mathrm{M}$ & $89-08-15$ & $738.38 \mathrm{H}$ & $93-03-08$ & $738.21 \mathrm{M}$ \\
\hline $85-07-23$ & $738.15 \mathrm{M}$ & $89-09-15$ & $738.38 \mathrm{H}$ & $93-05-05$ & $738.27 \mathrm{M}$ \\
\hline $85-08-08$ & $738.13 \mathrm{M}$ & $89-10-15$ & $738.37 \mathrm{H}$ & $93-05-24$ & $738.21 \mathrm{M}$ \\
\hline $85-10-04$ & $738.12 \mathrm{M}$ & $89-11-15$ & $738.34 \mathrm{H}$ & $93-06-21$ & $738.16 \mathrm{M}$ \\
\hline $85-12-30$ & $738.21 \mathrm{M}$ & $89-12-15$ & $738.32 \mathrm{H}$ & $93-11-18$ & $738.19 \mathrm{M}$ \\
\hline $86-01-28$ & $738.21 \mathrm{M}$ & $90-01-15$ & $738.32 \mathrm{H}$ & $93-12-22$ & $738.22 \mathrm{M}$ \\
\hline $86-02-13$ & $738.18 \mathrm{M}$ & $90-02-15$ & $738.31 \mathrm{H}$ & $94-01-31$ & $738.20 \mathrm{M}$ \\
\hline $86-03-24$ & $738.17 \mathrm{M}$ & $90-03-15$ & $738.34 \mathrm{H}$ & $94-02-28$ & $738.25 \mathrm{M}$ \\
\hline $86-04-21$ & $738.16 \mathrm{M}$ & $90-04-15$ & $738.35 \mathrm{H}$ & $94-03-28$ & $738.25 \mathrm{M}$ \\
\hline $86-05-14$ & $738.19 \mathrm{M}$ & $90-05-15$ & $738.33 \mathrm{H}$ & $94-04-29$ & $738.29 \mathrm{M}$ \\
\hline $86-06-12$ & $738.20 \mathrm{M}$ & $90-06-15$ & $738.32 \mathrm{H}$ & $94-05-12$ & $738.32 \mathrm{M}$ \\
\hline $86-08-06$ & $738.17 \mathrm{M}$ & $90-07-15$ & $738.37 \mathrm{H}$ & $94-06-07$ & $738.37 \mathrm{M}$ \\
\hline $86-09-15$ & $738.14 \mathrm{H}$ & $90-08-15$ & $738.39 \mathrm{H}$ & $94-07-15$ & $738.38 \mathrm{M}$ \\
\hline $86-10-15$ & $738.11 \mathrm{H}$ & $90-09-15$ & $738.46 \mathrm{H}$ & $94-08-15$ & $738.38 \mathrm{M}$ \\
\hline $86-11-15$ & $738.10 \mathrm{H}$ & $91-01-15$ & $738.47 \mathrm{H}$ & $94-09-28$ & $738.41 \mathrm{M}$ \\
\hline $86-12-15$ & $738.11 \mathrm{H}$ & $91-02-15$ & $738.45 \mathrm{H}$ & $94-10-13$ & $738.45 \mathrm{M}$ \\
\hline $87-01-15$ & $738.12 \mathrm{H}$ & $91-03-15$ & $738.46 \mathrm{H}$ & $94-11-03$ & $738.44 \mathrm{M}$ \\
\hline $87-02-15$ & $738.14 \mathrm{H}$ & $91-04-15$ & $738.38 \mathrm{H}$ & $94-12-13$ & $738.40 \mathrm{M}$ \\
\hline 87-03-15 & $738.15 \mathrm{H}$ & $91-05-15$ & $738.39 \mathrm{H}$ & $95-01-30$ & $738.28 \mathrm{M}$ \\
\hline $87-04-15$ & $738.14 \mathrm{H}$ & $91-06-15$ & $738.38 \mathrm{H}$ & $95-02-23$ & $738.32 \mathrm{M}$ \\
\hline $87-05-15$ & $738.13 \mathrm{H}$ & $91-07-15$ & $738.40 \mathrm{H}$ & $95-03-22$ & $738.39 \mathrm{M}$ \\
\hline $87-06-15$ & $738.11 \mathrm{H}$ & $91-08-15$ & $738.43 \mathrm{H}$ & $95-04-13$ & $738.31 \mathrm{M}$ \\
\hline $87-07-15$ & $738.12 \mathrm{H}$ & $91-09-15$ & $738.44 \mathrm{H}$ & $95-05-09$ & $738.29 \mathrm{M}$ \\
\hline $87-08-15$ & $738.12 \mathrm{H}$ & $92-01-15$ & $738.45 \mathrm{H}$ & $95-06-20$ & $738.30 \mathrm{M}$ \\
\hline $87-09-15$ & $738.19 \mathrm{H}$ & $92-02-15$ & $738.51 \mathrm{H}$ & $95-07-24$ & $738.31 \mathrm{M}$ \\
\hline $87-10-15$ & $738.21 \mathrm{H}$ & $92-05-11$ & $738.42 \mathrm{M}$ & $95-08-02$ & $738.30 \mathrm{M}$ \\
\hline $87-11-15$ & $738.19 \mathrm{H}$ & $92-06-04$ & $738.43 \mathrm{M}$ & $95-08-03$ & $738.30 \mathrm{M}$ \\
\hline $87-12-15$ & $738.16 \mathrm{H}$ & $92-06-23$ & $738.39 \mathrm{M}$ & 95-08-09 & $738.32 \mathrm{M}$ \\
\hline 88-03-15 & $738.16 \mathrm{H}$ & $92-07-17$ & $738.41 \mathrm{M}$ & 95-09-05 & $738.31 \mathrm{M}$ \\
\hline $88-04-15$ & $738.20 \mathrm{H}$ & $92-07-28$ & $738.37 \mathrm{M}$ & $95-09-12$ & $738.24 \mathrm{M}$ \\
\hline $88-06-15$ & $738.33 \mathrm{H}$ & $92-08-17$ & $738.31 \mathrm{M}$ & $95-10-23$ & $738.25 \mathrm{M}$ \\
\hline $88-07-15$ & $738.25 \mathrm{H}$ & $92-08-31$ & $738.29 \mathrm{M}$ & $95-12-04$ & $738.23 \mathrm{M}$ \\
\hline $88-08-15$ & $738.36 \mathrm{H}$ & $92-09-22$ & $738.19 \mathrm{M}$ & & \\
\hline $88-09-15$ & $738.57 \mathrm{H}$ & $92-09-29$ & $738.17 \mathrm{M}$ & & \\
\hline $88-10-15$ & $738.48 \mathrm{H}$ & $92-10-16$ & $738.25 \mathrm{M}$ & & \\
\hline
\end{tabular}

${ }^{1}$ Actual date of measurement applies to manual measurements only. For monthly mean water levels, the 15 th of each month was used. This was done to facilitate the plotting of the hydrographs for this report. 


\section{Well UE-25 WT\#17}

[M, indicates manual water-level measurement; $\mathrm{H}$, indicates monthly mean water levels averaged from hourly transducer data]

\begin{tabular}{|c|c|c|c|c|c|}
\hline $\begin{array}{c}\text { Date }^{1} \\
\text { (year-month-day) }\end{array}$ & $\begin{array}{c}\text { Water-level } \\
\text { altitude } \\
\text { (meters) }\end{array}$ & $\begin{array}{c}\text { Date }^{1} \\
\text { (year-month-day) }\end{array}$ & $\begin{array}{l}\text { Water-level } \\
\text { altitude } \\
\text { (meters) }\end{array}$ & $\begin{array}{c}\text { Date }^{1} \\
\text { (year-month-day) }\end{array}$ & $\begin{array}{l}\text { Water-level } \\
\text { altitude } \\
\text { (meters) }\end{array}$ \\
\hline $85-01-18$ & $729.55 \mathrm{M}$ & $88-05-24$ & $729.58 \mathrm{M}$ & $92-01-28$ & $729.76 \mathrm{M}$ \\
\hline $85-02-04$ & $729.45 \mathrm{M}$ & $88-06-29$ & $729.66 \mathrm{M}$ & $92-02-18$ & $729.72 \mathrm{M}$ \\
\hline $85-02-26$ & $729.49 \mathrm{M}$ & $88-07-13$ & $729.58 \mathrm{M}$ & $92-03-12$ & $729.78 \mathrm{M}$ \\
\hline $85-03-21$ & $729.49 \mathrm{M}$ & $88-09-22$ & $729.54 \mathrm{M}$ & $92-05-04$ & $729.78 \mathrm{M}$ \\
\hline $85-03-27$ & $729.48 \mathrm{M}$ & $88-10-27$ & $729.62 \mathrm{M}$ & $92-05-19$ & $729.80 \mathrm{M}$ \\
\hline $85-04-11$ & $729.50 \mathrm{M}$ & $88-11-28$ & $729.57 \mathrm{M}$ & $92-06-17$ & $729.76 \mathrm{M}$ \\
\hline $85-06-12$ & $729.67 \mathrm{M}$ & $88-12-20$ & $729.72 \mathrm{M}$ & $92-07-14$ & $729.73 \mathrm{M}$ \\
\hline $85-08-19$ & $729.65 \mathrm{M}$ & 89-01-09 & $729.70 \mathrm{M}$ & $92-08-19$ & $729.73 \mathrm{M}$ \\
\hline $85-11-20$ & $729.68 \mathrm{M}$ & $89-02-21$ & $729.78 \mathrm{M}$ & $92-09-10$ & $729.72 \mathrm{M}$ \\
\hline $86-01-27$ & $729.72 \mathrm{M}$ & $89-03-14$ & $729.76 \mathrm{M}$ & $92-10-20$ & $729.72 \mathrm{M}$ \\
\hline $86-02-12$ & $729.71 \mathrm{M}$ & $89-04-25$ & $729.74 \mathrm{M}$ & $92-11-19$ & $729.71 \mathrm{M}$ \\
\hline $86-03-20$ & $729.60 \mathrm{M}$ & $89-05-24$ & $729.75 \mathrm{M}$ & $92-12-28$ & $729.77 \mathrm{M}$ \\
\hline $86-04-03$ & $729.72 \mathrm{M}$ & $89-06-30$ & $729.76 \mathrm{M}$ & $93-01-20$ & $729.62 \mathrm{M}$ \\
\hline $86-05-15$ & $729.72 \mathrm{M}$ & 89-07-19 & $729.76 \mathrm{M}$ & $93-02-17$ & $729.68 \mathrm{M}$ \\
\hline $86-05-23$ & $729.66 \mathrm{M}$ & 89-08-09 & $729.75 \mathrm{M}$ & $93-03-11$ & $729.68 \mathrm{M}$ \\
\hline $86-06-12$ & $729.70 \mathrm{M}$ & $89-10-02$ & $729.83 \mathrm{M}$ & $93-04-23$ & $729.73 \mathrm{M}$ \\
\hline $86-07-08$ & $729.69 \mathrm{M}$ & $89-11-16$ & $729.81 \mathrm{M}$ & $93-05-12$ & $729.72 \mathrm{M}$ \\
\hline $86-08-11$ & $729.69 \mathrm{M}$ & $89-12-27$ & $729.81 \mathrm{M}$ & $94-01-06$ & $729.47 \mathrm{M}$ \\
\hline $86-08-29$ & $729.73 \mathrm{M}$ & $90-01-22$ & $729.78 \mathrm{M}$ & $94-02-02$ & $729.71 \mathrm{M}$ \\
\hline $86-09-14$ & $729.70 \mathrm{M}$ & $90-02-09$ & $729.72 \mathrm{M}$ & $94-03-01$ & $729.56 \mathrm{M}$ \\
\hline $86-10-01$ & $729.77 \mathrm{M}$ & $90-03-06$ & $729.72 \mathrm{M}$ & $94-03-16$ & $729.73 \mathrm{M}$ \\
\hline $86-10-29$ & $729.71 \mathrm{M}$ & $90-04-10$ & $729.72 \mathrm{M}$ & $94-05-02$ & $729.68 \mathrm{M}$ \\
\hline $86-11-29$ & $729.75 \mathrm{M}$ & $90-05-22$ & $729.73 \mathrm{M}$ & $94-05-26$ & $729.68 \mathrm{M}$ \\
\hline $86-12-11$ & $729.75 \mathrm{M}$ & $90-06-21$ & $729.79 \mathrm{M}$ & $94-06-30$ & $729.66 \mathrm{M}$ \\
\hline $86-12-26$ & $729.74 \mathrm{M}$ & $90-07-23$ & $729.78 \mathrm{M}$ & $94-07-19$ & $729.65 \mathrm{M}$ \\
\hline $87-01-13$ & $729.75 \mathrm{M}$ & $90-08-10$ & $729.76 \mathrm{M}$ & $94-08-31$ & $729.67 \mathrm{M}$ \\
\hline $87-01-26$ & $729.68 \mathrm{M}$ & $90-09-13$ & $729.78 \mathrm{M}$ & $94-09-30$ & $729.69 \mathrm{M}$ \\
\hline $87-02-12$ & $729.71 \mathrm{M}$ & $90-10-22$ & $729.76 \mathrm{M}$ & $94-10-20$ & $729.64 \mathrm{M}$ \\
\hline $87-03-10$ & $729.71 \mathrm{M}$ & $90-11-30$ & $729.78 \mathrm{M}$ & $94-12-02$ & $729.52 \mathrm{M}$ \\
\hline $87-04-08$ & $729.71 \mathrm{M}$ & $90-12-14$ & $729.79 \mathrm{M}$ & $95-03-15$ & $729.71 \mathrm{M}$ \\
\hline $87-05-28$ & $729.71 \mathrm{M}$ & $91-01-24$ & $729.77 \mathrm{M}$ & $95-04-17$ & $729.78 \mathrm{M}$ \\
\hline $87-06-08$ & $729.74 \mathrm{M}$ & $91-02-27$ & $729.84 \mathrm{M}$ & $95-06-01$ & $729.72 \mathrm{M}$ \\
\hline $87-06-24$ & $729.71 \mathrm{M}$ & $91-03-29$ & $729.75 \mathrm{M}$ & $95-06-28$ & $729.45 \mathrm{M}$ \\
\hline $87-07-13$ & $729.71 \mathrm{M}$ & $91-04-25$ & $729.79 \mathrm{M}$ & & \\
\hline $87-07-29$ & $729.71 \mathrm{M}$ & $91-05-13$ & $729.78 \mathrm{M}$ & & \\
\hline $87-08-25$ & $729.71 \mathrm{M}$ & $91-06-14$ & $729.75 \mathrm{M}$ & & \\
\hline $87-10-28$ & $729.71 \mathrm{M}$ & $91-07-24$ & $729.78 \mathrm{M}$ & & \\
\hline $87-11-27$ & $729.71 \mathrm{M}$ & $91-08-26$ & $729.77 \mathrm{M}$ & & \\
\hline $87-12-23$ & $729.71 \mathrm{M}$ & $91-09-30$ & $729.75 \mathrm{M}$ & & \\
\hline $88-01-26$ & $729.71 \mathrm{M}$ & $91-10-29$ & $729.81 \mathrm{M}$ & & \\
\hline $88-02-26$ & $729.75 \mathrm{M}$ & $91-11-20$ & $729.72 \mathrm{M}$ & & \\
\hline $88-04-25$ & $729.72 \mathrm{M}$ & $91-12-24$ & $729.79 \mathrm{M}$ & & \\
\hline
\end{tabular}

${ }^{1}$ Actual date of measurement applies to manual measurements only. For monthly mean water levels, the 15 th of each month was used. This was done to facilitate the plotting of the hydrographs for this report. 


\section{Well UE-25 WT\#18}

[M, indicates manual water-level measurement; $H$, indicates monthly mean water levels averaged from hourly transducer data]

\begin{tabular}{|c|c|}
\hline $\begin{array}{c}\text { Date }^{\top} \\
\text { (year-month-day) }\end{array}$ & $\begin{array}{c}\begin{array}{c}\text { Water-level altitude } \\
\text { (meters) }\end{array} \\
\end{array}$ \\
\hline $91-11-22$ & $730.79 \mathrm{M}$ \\
\hline $91-12-12$ & $730.86 \mathrm{M}$ \\
\hline $92-01-30$ & $730.85 \mathrm{M}$ \\
\hline $92-02-28$ & $730.85 \mathrm{M}$ \\
\hline $92-03-26$ & $730.92 \mathrm{M}$ \\
\hline $92-04-20$ & $730.87 \mathrm{M}$ \\
\hline $92-05-18$ & $730.87 \mathrm{M}$ \\
\hline $92-06-25$ & $730.87 \mathrm{M}$ \\
\hline $92-07-15$ & $730.85 \mathrm{M}$ \\
\hline $92-08-10$ & $730.80 \mathrm{M}$ \\
\hline $92-09-28$ & $730.76 \mathrm{M}$ \\
\hline $92-10-20$ & $730.77 \mathrm{M}$ \\
\hline $92-11-24$ & $730.78 \mathrm{M}$ \\
\hline $92-12-16$ & $730.76 \mathrm{M}$ \\
\hline $93-02-02$ & $730.75 \mathrm{M}$ \\
\hline $93-03-03$ & $730.77 \mathrm{M}$ \\
\hline $93-03-31$ & $730.77 \mathrm{M}$ \\
\hline $93-04-28$ & $730.76 \mathrm{M}$ \\
\hline $93-05-17$ & $730.75 \mathrm{M}$ \\
\hline $93-06-28$ & $730.78 \mathrm{M}$ \\
\hline $93-11-24$ & $730.80 \mathrm{M}$ \\
\hline $93-12-29$ & $730.81 \mathrm{M}$ \\
\hline $94-02-03$ & $730.75 \mathrm{M}$ \\
\hline 94-03-01 & $730.71 \mathrm{M}$ \\
\hline $94-03-16$ & $730.76 \mathrm{M}$ \\
\hline $94-04-21$ & $730.76 \mathrm{M}$ \\
\hline $94-05-26$ & $730.75 \mathrm{M}$ \\
\hline $94-06-30$ & $730.73 \mathrm{M}$ \\
\hline $94-07-19$ & $730.69 \mathrm{M}$ \\
\hline $94-08-31$ & $730.77 \mathrm{M}$ \\
\hline $94-09-23$ & $730.74 \mathrm{M}$ \\
\hline $94-10-24$ & $730.52 \mathrm{M}$ \\
\hline $94-11-10$ & $730.66 \mathrm{M}$ \\
\hline $94-12-14$ & $730.57 \mathrm{M}$ \\
\hline $95-01-30$ & $730.68 \mathrm{M}$ \\
\hline $95-03-02$ & $730.57 \mathrm{M}$ \\
\hline $95-03-22$ & $730.55 \mathrm{M}$ \\
\hline $95-04-10$ & $730.57 \mathrm{M}$ \\
\hline
\end{tabular}

${ }^{1}$ Actual date of measurement applies to manual measurements only. For monthly mean water levels, the 15 th of each month was used. This was done to facilitate the plotting of the hydrographs for this report. 


\section{Well UE-25 b\#1, Upper Zone}

[M, indicates manual water-level measurement; $\mathrm{H}$, indicates monthly mean water levels averaged from hourly transducer data]

\begin{tabular}{|c|c|c|c|c|c|}
\hline $\begin{array}{c}\text { Date }^{1} \\
\text { (year-month-day) }\end{array}$ & $\begin{array}{c}\text { Water-level } \\
\text { altitude } \\
\text { (meters) }\end{array}$ & $\begin{array}{c}\text { Date }^{1} \\
\text { (year-month-day) }\end{array}$ & $\begin{array}{l}\text { Water-level } \\
\text { altitude } \\
\text { (meters) }\end{array}$ & $\begin{array}{c}\text { Date }^{1} \\
\text { (year-month-day) }\end{array}$ & $\begin{array}{c}\text { Water-level } \\
\text { altitude } \\
\text { (meters) }\end{array}$ \\
\hline $85-09-15$ & $730.58 \mathrm{H}$ & $90-04-15$ & $730.79 \mathrm{H}$ & $94-07-19$ & $730.58 \mathrm{M}$ \\
\hline $85-10-15$ & $730.60 \mathrm{H}$ & $90-05-15$ & $730.72 \mathrm{H}$ & $94-08-18$ & $730.59 \mathrm{M}$ \\
\hline $85-11-15$ & $730.63 \mathrm{H}$ & $90-07-15$ & $730.71 \mathrm{H}$ & $94-09-27$ & $730.60 \mathrm{M}$ \\
\hline $85-12-15$ & $730.61 \mathrm{H}$ & $90-08-15$ & $730.68 \mathrm{H}$ & $94-10-20$ & $730.55 \mathrm{M}$ \\
\hline $86-01-15$ & $730.63 \mathrm{H}$ & $90-11-15$ & $730.71 \mathrm{H}$ & $94-11-09$ & $730.66 \mathrm{M}$ \\
\hline $86-02-15$ & $730.64 \mathrm{H}$ & $90-12-15$ & $730.76 \mathrm{H}$ & $94-12-27$ & $730.67 \mathrm{M}$ \\
\hline $86-03-15$ & $730.62 \mathrm{H}$ & $91-03-15$ & $730.66 \mathrm{H}$ & $95-01-30$ & $730.54 \mathrm{M}$ \\
\hline $86-04-15$ & $730.65 \mathrm{H}$ & $91-04-15$ & $730.65 \mathrm{H}$ & $95-03-02$ & $730.64 \mathrm{M}$ \\
\hline $86-05-15$ & $730.63 \mathrm{H}$ & $91-05-15$ & $730.70 \mathrm{H}$ & $95-04-10$ & $730.62 \mathrm{M}$ \\
\hline $86-06-15$ & $730.61 \mathrm{H}$ & $91-06-15$ & $730.72 \mathrm{H}$ & $95-05-10$ & $730.61 \mathrm{M}$ \\
\hline $86-07-15$ & $730.60 \mathrm{H}$ & $91-07-15$ & $730.71 \mathrm{H}$ & $95-06-13$ & $730.57 \mathrm{M}$ \\
\hline $86-08-15$ & $730.61 \mathrm{H}$ & $91-08-15$ & $730.70 \mathrm{H}$ & $95-07-12$ & $730.61 \mathrm{M}$ \\
\hline $86-09-15$ & $730.61 \mathrm{H}$ & $91-09-15$ & $730.72 \mathrm{H}$ & $95-08-16$ & $730.65 \mathrm{M}$ \\
\hline $86-10-15$ & $730.61 \mathrm{H}$ & $91-10-15$ & $730.72 \mathrm{H}$ & $95-09-14$ & $730.62 \mathrm{M}$ \\
\hline $86-11-15$ & $730.62 \mathrm{H}$ & $91-11-15$ & $730.71 \mathrm{H}$ & $95-12-05$ & $730.59 \mathrm{M}$ \\
\hline $86-12-15$ & $730.64 \mathrm{H}$ & $91-12-15$ & $730.72 \mathrm{H}$ & & \\
\hline $87-02-15$ & $730.65 \mathrm{H}$ & $92-01-15$ & $730.73 \mathrm{H}$ & & \\
\hline $87-03-15$ & $730.62 \mathrm{H}$ & $92-02-15$ & $730.74 \mathrm{H}$ & & \\
\hline $87-04-15$ & $730.64 \mathrm{H}$ & $92-03-15$ & $730.72 \mathrm{H}$ & & \\
\hline $87-05-15$ & $730.63 \mathrm{H}$ & $92-04-15$ & $730.72 \mathrm{H}$ & & \\
\hline $87-06-15$ & $730.63 \mathrm{H}$ & $92-05-15$ & $730.73 \mathrm{H}$ & & \\
\hline $87-07-15$ & $730.63 \mathrm{H}$ & $92-06-15$ & $730.75 \mathrm{H}$ & & \\
\hline $87-08-15$ & $730.60 \mathrm{H}$ & $92-07-15$ & $730.72 \mathrm{H}$ & & \\
\hline $87-09-15$ & $730.63 \mathrm{H}$ & $92-08-15$ & $730.70 \mathrm{H}$ & & \\
\hline $87-10-15$ & $730.57 \mathrm{H}$ & $92-09-15$ & $730.69 \mathrm{H}$ & & \\
\hline $88-02-15$ & $730.48 \mathrm{H}$ & $92-10-15$ & $730.68 \mathrm{H}$ & & \\
\hline $88-03-15$ & $730.52 \mathrm{H}$ & $92-11-15$ & $730.64 \mathrm{H}$ & & \\
\hline $88-04-15$ & $730.53 \mathrm{H}$ & $92-12-15$ & $730.66 \mathrm{H}$ & & \\
\hline $88-05-15$ & $730.58 \mathrm{H}$ & $93-01-15$ & $730.69 \mathrm{H}$ & & \\
\hline $88-06-15$ & $730.60 \mathrm{H}$ & $93-02-17$ & $730.60 \mathrm{M}$ & & \\
\hline $88-07-15$ & $730.59 \mathrm{H}$ & $93-03-24$ & $730.65 \mathrm{M}$ & & \\
\hline $88-08-15$ & $730.62 \mathrm{H}$ & $93-04-21$ & $730.61 \mathrm{M}$ & & \\
\hline $88-09-15$ & $730.62 \mathrm{H}$ & $93-05-13$ & $730.61 \mathrm{M}$ & & \\
\hline $88-10-15$ & $730.64 \mathrm{H}$ & $93-06-28$ & $730.64 \mathrm{M}$ & & \\
\hline $88-11-15$ & $730.68 \mathrm{H}$ & $93-11-19$ & $730.52 \mathrm{M}$ & & \\
\hline $89-02-15$ & $730.67 \mathrm{H}$ & $93-12-13$ & $730.60 \mathrm{M}$ & & \\
\hline $89-03-15$ & $730.73 \mathrm{H}$ & $94-01-31$ & $730.53 \mathrm{M}$ & & \\
\hline 89-04-15 & $730.73 \mathrm{H}$ & $94-02-28$ & $730.54 \mathrm{M}$ & & \\
\hline $89-05-15$ & $730.76 \mathrm{H}$ & $94-03-15$ & $730.59 \mathrm{M}$ & & \\
\hline $89-06-15$ & $730.79 \mathrm{H}$ & $94-04-21$ & $730.63 \mathrm{M}$ & & \\
\hline $89-07-15$ & $730.78 \mathrm{H}$ & $94-05-12$ & $730.61 \mathrm{M}$ & & \\
\hline $89-08-15$ & $730.77 \mathrm{H}$ & $94-06-24$ & $730.59 \mathrm{M}$ & & \\
\hline
\end{tabular}

${ }^{1}$ Actual date of measurement applies to manual measurements only. For monthly mean water levels, the 15 th of each month was used. This was done to facilitate the plotting of the hydrographs for this report. 


\section{Well UE-25 b\#1, Lower Zone}

$[\mathrm{M}$, indicates manual water-level measurement; $\mathrm{H}$, indicates monthly mean water levels averaged from hourly transducer data]

\begin{tabular}{|c|c|c|c|}
\hline $\begin{array}{c}\text { Date }^{1} \\
\text { (year-month-day) }\end{array}$ & $\begin{array}{l}\text { Water-level } \\
\text { altitude } \\
\text { (meters) }\end{array}$ & $\begin{array}{c}\text { Date }^{1} \\
\text { (year-month-day) }\end{array}$ & $\begin{array}{l}\text { Water-level } \\
\text { altitude } \\
\text { (meters) }\end{array}$ \\
\hline $85-03-15$ & $728.54 \mathrm{H}$ & $92-05-15$ & $729.81 \mathrm{H}$ \\
\hline $85-04-15$ & $728.53 \mathrm{H}$ & $92-06-15$ & $729.80 \mathrm{H}$ \\
\hline $85-05-15$ & $728.53 \mathrm{H}$ & $92-07-15$ & $729.82 \mathrm{H}$ \\
\hline $85-06-15$ & $728.52 \mathrm{H}$ & $92-08-15$ & $729.83 \mathrm{H}$ \\
\hline $85-07-15$ & $728.52 \mathrm{H}$ & $92-09-15$ & $729.86 \mathrm{H}$ \\
\hline $85-08-15$ & $728.58 \mathrm{H}$ & $92-10-15$ & $729.86 \mathrm{H}$ \\
\hline $85-09-15$ & $728.68 \mathrm{H}$ & $92-11-24$ & $729.92 \mathrm{M}$ \\
\hline $88-01-15$ & $729.42 \mathrm{H}$ & $92-12-15$ & $729.90 \mathrm{M}$ \\
\hline $88-02-15$ & $729.53 \mathrm{H}$ & $93-02-02$ & $729.92 \mathrm{M}$ \\
\hline $88-03-15$ & $729.52 \mathrm{H}$ & $94-01-19$ & $730.09 \mathrm{M}$ \\
\hline $88-04-15$ & $729.49 \mathrm{H}$ & $94-03-17$ & $730.09 \mathrm{M}$ \\
\hline $88-05-15$ & $729.49 \mathrm{H}$ & $94-04-25$ & $730.07 \mathrm{M}$ \\
\hline $88-06-15$ & $729.57 \mathrm{H}$ & $94-05-31$ & $730.10 \mathrm{M}$ \\
\hline $88-07-15$ & $729.69 \mathrm{H}$ & $94-06-23$ & $730.11 \mathrm{M}$ \\
\hline $88-08-15$ & $729.84 \mathrm{H}$ & $94-07-21$ & $730.09 \mathrm{M}$ \\
\hline $88-09-15$ & $729.89 \mathrm{H}$ & $94-08-12$ & $730.00 \mathrm{M}$ \\
\hline $88-10-15$ & $729.78 \mathrm{H}$ & $94-09-27$ & $730.04 \mathrm{M}$ \\
\hline $88-11-15$ & $729.76 \mathrm{H}$ & $94-10-19$ & $730.00 \mathrm{M}$ \\
\hline $88-12-15$ & $729.76 \mathrm{H}$ & $94-11-30$ & $729.96 \mathrm{M}$ \\
\hline $89-01-15$ & $729.68 \mathrm{H}$ & $95-03-08$ & $730.25 \mathrm{M}$ \\
\hline $89-02-15$ & $729.68 \mathrm{H}$ & $95-04-25$ & $730.25 \mathrm{M}$ \\
\hline $89-03-15$ & $729.67 \mathrm{H}$ & $95-05-31$ & $729.68 \mathrm{M}$ \\
\hline $89-04-15$ & $729.66 \mathrm{H}$ & $95-06-22$ & $729.64 \mathrm{M}$ \\
\hline $89-05-15$ & $729.67 \mathrm{H}$ & $95-07-18$ & $730.14 \mathrm{M}$ \\
\hline $89-06-15$ & $729.67 \mathrm{H}$ & & \\
\hline $89-07-15$ & $729.68 \mathrm{H}$ & & \\
\hline $89-08-15$ & $729.71 \mathrm{H}$ & & \\
\hline $89-09-15$ & $729.74 \mathrm{H}$ & & \\
\hline $89-11-15$ & $729.81 \mathrm{H}$ & & \\
\hline $89-12-15$ & $729.81 \mathrm{H}$ & & \\
\hline $90-02-27$ & $729.79 \mathrm{M}$ & & \\
\hline $90-06-12$ & $729.80 \mathrm{M}$ & & \\
\hline $90-10-01$ & $729.83 \mathrm{M}$ & & \\
\hline $91-01-31$ & $729.90 \mathrm{M}$ & & \\
\hline $91-02-06$ & $729.59 \mathrm{M}$ & & \\
\hline $91-02-08$ & $729.57 \mathrm{M}$ & & \\
\hline $91-04-16$ & $729.55 \mathrm{M}$ & & \\
\hline $91-07-17$ & $729.60 \mathrm{M}$ & & \\
\hline $91-10-08$ & $729.62 \mathrm{M}$ & & \\
\hline $91-10-09$ & $729.61 \mathrm{M}$ & & \\
\hline $92-02-26$ & $729.77 \mathrm{M}$ & & \\
\hline $92-02-27$ & $729.80 \mathrm{M}$ & & \\
\hline $92-03-10$ & $729.78 \mathrm{M}$ & & \\
\hline
\end{tabular}

${ }^{1}$ Actual date of measurement applies to manual measurements only. For monthly mean water levels, the 15 th of each month was used. This was done to facilitate the plotting of the hydrographs for this report. 


\section{Well UE-25 p\#1}

[M, indicates manual water-level measurement; $\mathrm{H}$, indicates monthly mean water levels averaged from hourly transducer data]

\begin{tabular}{|c|c|c|c|c|c|}
\hline $\begin{array}{c}\text { Date }^{1} \\
\text { (year-month-day) }\end{array}$ & $\begin{array}{c}\text { Water-level } \\
\text { altitude } \\
\text { (meters) }\end{array}$ & $\begin{array}{c}\text { Date }^{t} \\
\text { (year-month-day) }\end{array}$ & $\begin{array}{c}\text { Water-level } \\
\text { altitude } \\
\text { (meters) }\end{array}$ & $\begin{array}{c}\text { Date }^{1} \\
\text { (year-month-day) }\end{array}$ & $\begin{array}{c}\text { Water-level } \\
\text { altitude } \\
\text { (meters) }\end{array}$ \\
\hline $85-03-15$ & $751.92 \mathrm{H}$ & $88-11-15$ & $752.69 \mathrm{H}$ & $93-01-15$ & $752.44 \mathrm{H}$ \\
\hline $85-04-15$ & $752.00 \mathrm{H}$ & $89-02-15$ & $752.55 \mathrm{H}$ & $93-02-15$ & $752.48 \mathrm{H}$ \\
\hline $85-05-15$ & $752.03 \mathrm{H}$ & $89-03-15$ & $752.57 \mathrm{H}$ & $93-03-15$ & $752.47 \mathrm{H}$ \\
\hline $85-06-15$ & $752.10 \mathrm{H}$ & $89-04-15$ & $752.58 \mathrm{H}$ & $93-04-15$ & $752.50 \mathrm{H}$ \\
\hline $85-07-15$ & $752.12 \mathrm{H}$ & $89-05-15$ & $752.58 \mathrm{H}$ & $93-05-15$ & $752.49 \mathrm{H}$ \\
\hline $85-08-15$ & $752.16 \mathrm{H}$ & $89-06-15$ & $752.57 \mathrm{H}$ & $93-06-15$ & $752.47 \mathrm{H}$ \\
\hline $85-09-15$ & $752.17 \mathrm{H}$ & $89-07-15$ & $752.54 \mathrm{H}$ & $93-07-15$ & $752.48 \mathrm{H}$ \\
\hline $85-10-15$ & $752.18 \mathrm{H}$ & $89-08-15$ & $752.55 \mathrm{H}$ & $93-08-15$ & $752.50 \mathrm{H}$ \\
\hline $85-11-15$ & $752.21 \mathrm{H}$ & $89-09-15$ & $752.53 \mathrm{H}$ & $93-09-15$ & $752.51 \mathrm{H}$ \\
\hline $85-12-15$ & $752.18 \mathrm{H}$ & $89-11-15$ & $752.46 \mathrm{H}$ & $93-10-15$ & $752.52 \mathrm{H}$ \\
\hline $86-01-15$ & $752.15 \mathrm{H}$ & $89-12-15$ & $752.48 \mathrm{H}$ & $93-11-15$ & $752.52 \mathrm{H}$ \\
\hline $86-02-15$ & $752.21 \mathrm{H}$ & $90-01-15$ & $752.50 \mathrm{H}$ & $93-12-15$ & $752.51 \mathrm{H}$ \\
\hline $86-03-15$ & $752.21 \mathrm{H}$ & $90-02-15$ & $752.51 \mathrm{H}$ & $94-01-15$ & $752.48 \mathrm{H}$ \\
\hline $86-04-15$ & $752.26 \mathrm{H}$ & $90-03-15$ & $752.54 \mathrm{H}$ & $94-02-15$ & $752.47 \mathrm{H}$ \\
\hline $86-05-15$ & $752.25 \mathrm{H}$ & $90-04-15$ & $752.55 \mathrm{H}$ & $94-03-15$ & $752.48 \mathrm{H}$ \\
\hline $86-06-15$ & $752.21 \mathrm{H}$ & $90-06-15$ & $752.51 \mathrm{H}$ & $94-04-15$ & $752.56 \mathrm{H}$ \\
\hline $86-07-15$ & $752.25 \mathrm{H}$ & $90-07-15$ & $752.54 \mathrm{H}$ & $94-05-15$ & $752.59 \mathrm{H}$ \\
\hline $86-08-15$ & $752.26 \mathrm{H}$ & $90-08-15$ & $752.61 \mathrm{H}$ & $94-06-15$ & $752.60 \mathrm{H}$ \\
\hline $86-09-15$ & $752.33 \mathrm{H}$ & $90-09-15$ & $752.65 \mathrm{H}$ & $94-07-15$ & $752.60 \mathrm{H}$ \\
\hline $86-10-15$ & $752.34 \mathrm{H}$ & $90-11-15$ & $752.55 \mathrm{H}$ & $94-08-15$ & $752.60 \mathrm{H}$ \\
\hline $86-11-15$ & $752.37 \mathrm{H}$ & $90-12-15$ & $752.49 \mathrm{H}$ & $94-09-15$ & $752.56 \mathrm{H}$ \\
\hline $86-12-15$ & $752.41 \mathrm{H}$ & $91-01-15$ & $752.37 \mathrm{H}$ & $94-10-15$ & $752.57 \mathrm{H}$ \\
\hline $87-01-15$ & $752.46 \mathrm{H}$ & $91-04-15$ & $752.40 \mathrm{H}$ & $94-11-15$ & $752.57 \mathrm{H}$ \\
\hline $87-02-15$ & $752.51 \mathrm{H}$ & $91-05-15$ & $752.41 \mathrm{H}$ & $94-12-15$ & $752.55 \mathrm{H}$ \\
\hline $87-03-15$ & $752.57 \mathrm{H}$ & $91-06-15$ & $752.44 \mathrm{H}$ & $95-01-15$ & $752.55 \mathrm{H}$ \\
\hline $87-05-15$ & $752.44 \mathrm{H}$ & $91-07-15$ & $752.45 \mathrm{H}$ & $95-02-15$ & $752.54 \mathrm{H}$ \\
\hline $87-06-15$ & $752.42 \mathrm{H}$ & $91-08-15$ & $752.46 \mathrm{H}$ & $95-03-15$ & $752.58 \mathrm{H}$ \\
\hline $87-07-15$ & $752.44 \mathrm{H}$ & $91-10-15$ & $752.53 \mathrm{H}$ & $95-04-15$ & $752.59 \mathrm{H}$ \\
\hline $87-08-15$ & $752.40 \mathrm{H}$ & $91-11-15$ & $752.50 \mathrm{H}$ & $95-05-15$ & $752.59 \mathrm{H}$ \\
\hline $87-09-15$ & $752.37 \mathrm{H}$ & $91-12-15$ & $752.49 \mathrm{H}$ & $95-06-15$ & $752.58 \mathrm{H}$ \\
\hline $87-10-15$ & $752.33 \mathrm{H}$ & $92-01-15$ & $752.49 \mathrm{H}$ & $95-07-15$ & $752.58 \mathrm{H}$ \\
\hline $87-11-15$ & $752.38 \mathrm{H}$ & $92-02-15$ & $752.50 \mathrm{H}$ & $95-08-15$ & $752.59 \mathrm{H}$ \\
\hline $87-12-15$ & $752.48 \mathrm{H}$ & $92-03-15$ & $752.53 \mathrm{H}$ & $95-09-15$ & $752.57 \mathrm{H}$ \\
\hline $88-01-15$ & $752.54 \mathrm{H}$ & $92-04-15$ & $752.49 \mathrm{H}$ & $95-10-15$ & $752.56 \mathrm{H}$ \\
\hline $88-02-15$ & $752.54 \mathrm{H}$ & $92-05-15$ & $752.46 \mathrm{H}$ & $95-11-15$ & $752.52 \mathrm{H}$ \\
\hline $88-03-15$ & $752.54 \mathrm{H}$ & $92-06-15$ & $752.46 \mathrm{H}$ & $95-12-15$ & $752.55 \mathrm{H}$ \\
\hline $88-04-15$ & $752.57 \mathrm{H}$ & $92-07-15$ & $751.98 \mathrm{H}$ & & \\
\hline $88-06-15$ & $752.52 \mathrm{H}$ & $92-08-15$ & $752.07 \mathrm{H}$ & & \\
\hline $88-07-15$ & $752.46 \mathrm{H}$ & $92-09-15$ & $752.07 \mathrm{H}$ & & \\
\hline $88-08-15$ & $752.54 \mathrm{H}$ & $92-10-15$ & $752.19 \mathrm{H}$ & & \\
\hline $88-09-15$ & $752.52 \mathrm{H}$ & $92-11-15$ & $752.28 \mathrm{H}$ & & \\
\hline $88-10-15$ & $752.61 \mathrm{H}$ & $92-12-15$ & $752.42 \mathrm{H}$ & & \\
\hline
\end{tabular}

${ }^{1}$ Actual date of measurement applies to manual measurements only. For monthly mean water levels, the 15 th of each month was used. This was done to facilitate the plotting of the hydrographs for this report. 


\section{Well USW VH-1}

$[\mathrm{M}$, indicates manual water-level measurement; $\mathrm{H}$, indicates monthly mean water levels averaged from hourly transducer data]

\begin{tabular}{|c|c|c|c|c|c|}
\hline $\begin{array}{c}\text { Date }^{1} \\
\text { (year-month-day) }\end{array}$ & $\begin{array}{l}\text { Water-level } \\
\text { altitude } \\
\text { (meters) }\end{array}$ & $\begin{array}{c}\text { Date }^{1} \\
\text { (year-month-day) }\end{array}$ & $\begin{array}{l}\text { Water-level } \\
\text { altitude } \\
\text { (meters) }\end{array}$ & $\begin{array}{c}\text { Date }^{1} \\
\text { (year-month-day) }\end{array}$ & $\begin{array}{l}\text { Water-level } \\
\text { altitude } \\
\text { (meters) }\end{array}$ \\
\hline $85-01-03$ & $779.37 \mathrm{M}$ & $87-12-03$ & $779.41 \mathrm{M}$ & $91-09-27$ & $779.51 \mathrm{M}$ \\
\hline $85-01-17$ & $779.35 \mathrm{M}$ & $87-12-16$ & $779.50 \mathrm{M}$ & $92-01-28$ & $779.48 \mathrm{M}$ \\
\hline $85-02-01$ & $779.42 \mathrm{M}$ & $88-01-22$ & $779.30 \mathrm{M}$ & $92-02-14$ & $779.41 \mathrm{M}$ \\
\hline $85-02-06$ & $779.33 \mathrm{M}$ & $88-02-24$ & $779.37 \mathrm{M}$ & $92-02-24$ & $779.41 \mathrm{M}$ \\
\hline $85-02-21$ & $779.37 \mathrm{M}$ & 88-03-07 & $779.31 \mathrm{M}$ & $92-03-12$ & $779.41 \mathrm{M}$ \\
\hline $85-03-18$ & $779.32 \mathrm{M}$ & $88-04-05$ & $779.34 \mathrm{M}$ & $92-03-24$ & $779.38 \mathrm{M}$ \\
\hline $85-04-16$ & $779.40 \mathrm{M}$ & $88-05-17$ & $779.46 \mathrm{M}$ & $92-04-13$ & $779.43 \mathrm{M}$ \\
\hline $85-06-21$ & $779.43 \mathrm{M}$ & $88-06-23$ & $779.42 \mathrm{M}$ & $92-04-23$ & $779.39 \mathrm{M}$ \\
\hline $85-07-17$ & $779.41 \mathrm{M}$ & $88-07-08$ & $779.43 \mathrm{M}$ & $92-05-08$ & $779.35 \mathrm{M}$ \\
\hline $85-08-07$ & $779.41 \mathrm{M}$ & $88-08-17$ & $779.42 \mathrm{M}$ & $92-05-26$ & $779.45 \mathrm{M}$ \\
\hline $85-08-21$ & $779.41 \mathrm{M}$ & $88-09-15$ & $779.45 \mathrm{M}$ & $92-06-05$ & $779.47 \mathrm{M}$ \\
\hline $85-09-03$ & $779.43 \mathrm{M}$ & $88-10-06$ & $779.46 \mathrm{M}$ & $92-06-18$ & $779.46 \mathrm{M}$ \\
\hline $85-09-30$ & $779.45 \mathrm{M}$ & $88-11-17$ & $779.44 \mathrm{M}$ & $92-07-13$ & $779.42 \mathrm{M}$ \\
\hline $85-10-16$ & $779.45 \mathrm{M}$ & $88-12-21$ & $779.47 \mathrm{M}$ & $92-07-29$ & $779.45 \mathrm{M}$ \\
\hline $85-10-31$ & $779.43 \mathrm{M}$ & 89-01-19 & $779.53 \mathrm{M}$ & $92-07-31$ & $779.41 \mathrm{M}$ \\
\hline $85-11-29$ & $779.45 \mathrm{M}$ & $89-02-16$ & $779.54 \mathrm{M}$ & $92-08-12$ & $779.45 \mathrm{M}$ \\
\hline $85-12-13$ & $779.45 \mathrm{M}$ & $89-03-23$ & $779.49 \mathrm{M}$ & $92-08-27$ & $779.41 \mathrm{M}$ \\
\hline $86-01-22$ & $779.42 \mathrm{M}$ & $89-04-21$ & $779.49 \mathrm{M}$ & $92-09-08$ & $779.45 \mathrm{M}$ \\
\hline $86-02-25$ & $779.43 \mathrm{M}$ & $89-05-18$ & $779.47 \mathrm{M}$ & $92-09-18$ & $779.44 \mathrm{M}$ \\
\hline 86-03-19 & $779.41 \mathrm{M}$ & $89-07-18$ & $779.46 \mathrm{M}$ & $92-10-14$ & $779.47 \mathrm{M}$ \\
\hline $86-04-17$ & $779.44 \mathrm{M}$ & $89-10-04$ & $779.46 \mathrm{M}$ & $92-10-23$ & $779.44 \mathrm{M}$ \\
\hline $86-04-29$ & $779.45 \mathrm{M}$ & $89-11-28$ & $779.37 \mathrm{M}$ & $92-11-02$ & $779.44 \mathrm{M}$ \\
\hline 86-06-04 & $779.44 \mathrm{M}$ & $89-12-21$ & $779.45 \mathrm{M}$ & $92-11-20$ & $779.43 \mathrm{M}$ \\
\hline $86-07-02$ & $779.42 \mathrm{M}$ & $90-01-30$ & $779.60 \mathrm{M}$ & $92-12-01$ & $779.48 \mathrm{M}$ \\
\hline $86-08-04$ & $779.43 \mathrm{M}$ & $90-02-28$ & $779.47 \mathrm{M}$ & $92-12-23$ & $779.41 \mathrm{M}$ \\
\hline $86-09-04$ & $779.41 \mathrm{M}$ & $90-03-16$ & $779.46 \mathrm{M}$ & $93-01-13$ & $779.48 \mathrm{M}$ \\
\hline $86-09-30$ & $779.43 \mathrm{M}$ & $90-04-18$ & $779.47 \mathrm{M}$ & $93-02-04$ & $779.48 \mathrm{M}$ \\
\hline $86-10-31$ & $779.44 \mathrm{M}$ & $90-06-15$ & $779.46 \mathrm{M}$ & $93-02-18$ & $779.48 \mathrm{M}$ \\
\hline $86-11-20$ & $779.41 \mathrm{M}$ & $90-07-02$ & $779.52 \mathrm{M}$ & $93-03-02$ & $779.46 \mathrm{M}$ \\
\hline $86-12-05$ & $779.48 \mathrm{M}$ & $90-08-17$ & $779.47 \mathrm{M}$ & $93-03-26$ & $779.49 \mathrm{M}$ \\
\hline $87-01-14$ & $779.48 \mathrm{M}$ & $90-09-26$ & $779.46 \mathrm{M}$ & 93-04-09 & $779.48 \mathrm{M}$ \\
\hline $87-02-05$ & $779.35 \mathrm{M}$ & $90-10-03$ & $779.43 \mathrm{M}$ & $93-04-22$ & $779.51 \mathrm{M}$ \\
\hline $87-03-05$ & $779.35 \mathrm{M}$ & $90-11-21$ & $779.40 \mathrm{M}$ & $93-05-11$ & $779.48 \mathrm{M}$ \\
\hline $87-05-14$ & $779.36 \mathrm{M}$ & $90-12-21$ & $779.41 \mathrm{M}$ & $93-05-28$ & $779.46 \mathrm{M}$ \\
\hline $87-05-27$ & $779.41 \mathrm{M}$ & $91-01-30$ & $779.43 \mathrm{M}$ & $93-06-14$ & $779.47 \mathrm{M}$ \\
\hline $87-06-17$ & $779.44 \mathrm{M}$ & $91-02-21$ & $779.51 \mathrm{M}$ & $93-06-25$ & $779.46 \mathrm{M}$ \\
\hline $87-07-14$ & $779.45 \mathrm{M}$ & $91-03-28$ & $779.41 \mathrm{M}$ & $93-07-16$ & $779.45 \mathrm{M}$ \\
\hline $87-08-06$ & $779.43 \mathrm{M}$ & $91-04-26$ & $779.44 \mathrm{M}$ & $93-11-09$ & $779.41 \mathrm{M}$ \\
\hline $87-08-27$ & $779.42 \mathrm{M}$ & $91-05-21$ & $779.51 \mathrm{M}$ & $93-12-23$ & $779.39 \mathrm{M}$ \\
\hline $87-09-17$ & $779.42 \mathrm{M}$ & $91-06-20$ & $779.49 \mathrm{M}$ & $94-02-01$ & $779.43 \mathrm{M}$ \\
\hline $87-10-21$ & $779.47 \mathrm{M}$ & $91-07-29$ & $779.51 \mathrm{M}$ & $94-02-25$ & $779.47 \mathrm{M}$ \\
\hline $87-11-18$ & $779.34 \mathrm{M}$ & $91-08-29$ & $779.44 \mathrm{M}$ & & \\
\hline
\end{tabular}

${ }^{1}$ Actual date of measurement applies to manual measurements only. For monthly mean water levels, the 15 th of each month was used. This was done to facilitate the plotting of the hydrographs for this report. 


\section{Well USW VH-1-Continued}

[M, indicates manual water-level measurement; $\mathrm{H}$, indicates monthly mean water levels averaged from hourly transducer data]

\begin{tabular}{cc}
\hline $\begin{array}{c}\text { Date } \\
\text { (year-month-day) }\end{array}$ & $\begin{array}{c}\text { Water-level altitude } \\
\text { (meters) }\end{array}$ \\
\hline $94-03-29$ & $779.46 \mathrm{M}$ \\
$94-04-22$ & $779.47 \mathrm{M}$ \\
$94-05-05$ & $779.49 \mathrm{M}$ \\
$94-06-08$ & $779.42 \mathrm{M}$ \\
$94-07-29$ & $779.47 \mathrm{M}$ \\
$94-08-25$ & $779.47 \mathrm{M}$ \\
$94-09-22$ & $779.48 \mathrm{M}$ \\
$94-10-26$ & $779.48 \mathrm{M}$ \\
$94-11-22$ & $779.41 \mathrm{M}$ \\
$94-12-09$ & $779.44 \mathrm{M}$ \\
$94-12-09$ & $779.44 \mathrm{M}$ \\
$95-01-05$ & $779.53 \mathrm{M}$ \\
$95-01-12$ & $779.45 \mathrm{M}$ \\
$95-02-21$ & $779.52 \mathrm{M}$ \\
$95-03-28$ & $779.50 \mathrm{M}$ \\
$95-04-19$ & $779.51 \mathrm{M}$ \\
$95-05-17$ & $779.49 \mathrm{M}$ \\
$95-06-22$ & $779.45 \mathrm{M}$ \\
$95-07-19$ & $779.44 \mathrm{M}$ \\
$95-08-10$ & $779.51 \mathrm{M}$ \\
$95-10-24$ & $779.49 \mathrm{M}$ \\
$95-12-06$ & $779.50 \mathrm{M}$ \\
\hline 19601 &
\end{tabular}

${ }^{1}$ Actual date of measurement applies to manual measurements only. For monthly mean water levels, the 15 th of each month was used. This was done to facilitate the plotting of the hydrographs for this report. 


\section{Well USW G-2}

$[M$, indicates manual water-level measurement; $H$, indicates monthly mean water levels averaged from hourly transducer data]

\begin{tabular}{|c|c|}
\hline $\begin{array}{c}\text { Date' }^{\prime} \\
\text { (year-month-day) }\end{array}$ & $\begin{array}{c}\text { Water-level altitude } \\
\text { (meters) }\end{array}$ \\
\hline $92-09-28$ & $1,020.51 \mathrm{M}$ \\
\hline $92-10-20$ & $1,020.56 \mathrm{M}$ \\
\hline $92-11-24$ & $1,020.54 \mathrm{M}$ \\
\hline $92-12-16$ & $1,020.47 \mathrm{M}$ \\
\hline $93-02-03$ & $1,020.38 \mathrm{M}$ \\
\hline $93-03-10$ & $1,020.36 \mathrm{M}$ \\
\hline $93-04-19$ & $1,020.34 \mathrm{M}$ \\
\hline $93-05-07$ & $1,020.37 \mathrm{M}$ \\
\hline $93-06-28$ & $1,020.37 \mathrm{M}$ \\
\hline $93-10-20$ & $1,020.17 \mathrm{M}$ \\
\hline $93-11-24$ & $1,020.18 \mathrm{M}$ \\
\hline $93-12-29$ & $1,020.11 \mathrm{M}$ \\
\hline $94-02-03$ & $1,020.18 \mathrm{M}$ \\
\hline $94-02-18$ & $1,020.30 \mathrm{M}$ \\
\hline $94-03-15$ & $1,020.12 \mathrm{H}$ \\
\hline $94-04-15$ & $1,020.11 \mathrm{H}$ \\
\hline $94-05-15$ & $1,020.09 \mathrm{H}$ \\
\hline $94-06-15$ & $1,020.09 \mathrm{H}$ \\
\hline $94-07-15$ & $1,020.11 \mathrm{H}$ \\
\hline $94-08-15$ & $1,020.10 \mathrm{H}$ \\
\hline $94-09-15$ & $1,020.09 \mathrm{H}$ \\
\hline $94-10-15$ & $1,020.10 \mathrm{H}$ \\
\hline $94-11-14$ & $1,019.98 \mathrm{M}$ \\
\hline $94-12-14$ & $1,020.04 \mathrm{M}$ \\
\hline $95-10-10$ & $1,019.91 \mathrm{M}$ \\
\hline $95-11-02$ & $1,019.58 \mathrm{M}$ \\
\hline $95-12-05$ & $1,019.74 \mathrm{M}$ \\
\hline $95-12-11$ & $1,019.75 \mathrm{M}$ \\
\hline
\end{tabular}

${ }^{1}$ Actual date of measurement applies to manual measurements only. For monthly mean water levels, the 15 th of each month was used. This was done to facilitate the plotting of the hydrographs for this report. 


\section{Well USW G-3}

[M, indicates manual water-level measurement; $\mathrm{H}$, indicates monthly mean water levels averaged from hourly transducer data]

\begin{tabular}{|c|c|c|c|c|c|}
\hline $\begin{array}{c}\text { Date }^{1} \\
\text { (year-month-day) }\end{array}$ & $\begin{array}{l}\text { Water-level } \\
\text { altitude } \\
\text { (meters) }\end{array}$ & $\begin{array}{c}\text { Date }^{1} \\
\text { (year-month-day) }\end{array}$ & $\begin{array}{c}\text { Water-level } \\
\text { altitude } \\
\text { (meters) }\end{array}$ & $\begin{array}{c}\text { Date }^{1} \\
\text { (year-month-day) }\end{array}$ & $\begin{array}{c}\text { Water-level } \\
\text { altitude } \\
\text { (meters) }\end{array}$ \\
\hline $85-01-04$ & $729.96 \mathrm{M}$ & $89-02-15$ & $730.37 \mathrm{H}$ & $92-11-15$ & $730.63 \mathrm{H}$ \\
\hline $85-01-18$ & $730.20 \mathrm{M}$ & $89-03-15$ & $730.39 \mathrm{H}$ & $92-12-15$ & $730.60 \mathrm{H}$ \\
\hline $85-02-05$ & $730.08 \mathrm{M}$ & $89-04-15$ & $730.37 \mathrm{H}$ & $93-01-15$ & $730.58 \mathrm{H}$ \\
\hline $85-02-25$ & $730.16 \mathrm{M}$ & $89-05-15$ & $730.34 \mathrm{H}$ & $93-02-15$ & $730.62 \mathrm{H}$ \\
\hline $85-03-05$ & $730.03 \mathrm{M}$ & $89-06-15$ & $730.37 \mathrm{H}$ & $93-03-15$ & $730.54 \mathrm{H}$ \\
\hline $85-03-29$ & $730.23 \mathrm{M}$ & $89-07-15$ & $730.36 \mathrm{H}$ & $93-04-15$ & $730.53 \mathrm{H}$ \\
\hline $85-04-12$ & $730.22 \mathrm{M}$ & $89-09-15$ & $730.36 \mathrm{H}$ & $93-05-15$ & $730.56 \mathrm{H}$ \\
\hline $85-06-20$ & $730.63 \mathrm{M}$ & $89-10-15$ & $730.36 \mathrm{H}$ & $93-06-15$ & $730.54 \mathrm{H}$ \\
\hline $85-08-06$ & $730.62 \mathrm{M}$ & $90-01-15$ & $730.43 \mathrm{H}$ & $93-07-15$ & $730.50 \mathrm{H}$ \\
\hline $85-11-20$ & $730.08 \mathrm{M}$ & $90-02-15$ & $730.44 \mathrm{H}$ & $93-08-15$ & $730.49 \mathrm{H}$ \\
\hline $86-01-27$ & $730.63 \mathrm{M}$ & $90-03-15$ & $730.51 \mathrm{H}$ & $93-09-15$ & $730.52 \mathrm{H}$ \\
\hline $86-02-11$ & $730.65 \mathrm{M}$ & $90-04-15$ & $730.51 \mathrm{H}$ & $93-10-15$ & $730.60 \mathrm{H}$ \\
\hline $86-03-12$ & $730.69 \mathrm{M}$ & $90-05-15$ & $730.47 \mathrm{H}$ & $93-11-15$ & $730.68 \mathrm{H}$ \\
\hline $86-03-13$ & $730.70 \mathrm{M}$ & $90-06-15$ & $730.43 \mathrm{H}$ & $93-12-15$ & $730.73 \mathrm{H}$ \\
\hline $86-05-15$ & $730.62 \mathrm{H}$ & $90-07-15$ & $730.42 \mathrm{H}$ & $94-01-15$ & $730.70 \mathrm{H}$ \\
\hline $86-06-15$ & $730.62 \mathrm{H}$ & $90-08-15$ & $730.46 \mathrm{H}$ & $94-02-15$ & $730.67 \mathrm{H}$ \\
\hline $86-07-15$ & $730.67 \mathrm{H}$ & $90-09-15$ & $730.51 \mathrm{H}$ & $94-03-15$ & $730.60 \mathrm{H}$ \\
\hline $86-09-15$ & $730.65 \mathrm{H}$ & $90-10-15$ & $730.53 \mathrm{H}$ & $94-04-15$ & $730.56 \mathrm{H}$ \\
\hline $86-10-15$ & $730.59 \mathrm{H}$ & $90-11-15$ & $730.51 \mathrm{H}$ & $94-05-31$ & $730.48 \mathrm{M}$ \\
\hline $86-11-15$ & $730.63 \mathrm{H}$ & $90-12-15$ & $730.51 \mathrm{H}$ & $94-06-24$ & $730.43 \mathrm{M}$ \\
\hline $87-01-15$ & $730.65 \mathrm{H}$ & $91-01-15$ & $730.47 \mathrm{H}$ & $94-07-20$ & $730.42 \mathrm{M}$ \\
\hline $87-02-15$ & $730.67 \mathrm{H}$ & $91-02-15$ & $730.46 \mathrm{H}$ & $94-08-17$ & $730.31 \mathrm{M}$ \\
\hline $87-03-15$ & $730.66 \mathrm{H}$ & $91-03-15$ & $730.42 \mathrm{H}$ & $94-09-14$ & $730.27 \mathrm{M}$ \\
\hline $87-04-15$ & $730.65 \mathrm{H}$ & $91-04-15$ & $730.40 \mathrm{H}$ & $94-10-24$ & $730.24 \mathrm{M}$ \\
\hline $87-05-15$ & $730.68 \mathrm{H}$ & $91-05-15$ & $730.41 \mathrm{H}$ & $94-12-01$ & $730.31 \mathrm{M}$ \\
\hline $87-06-15$ & $730.71 \mathrm{H}$ & $91-06-15$ & $730.42 \mathrm{H}$ & $95-03-15$ & $730.74 \mathrm{M}$ \\
\hline $87-07-15$ & $730.73 \mathrm{H}$ & $91-07-15$ & $730.40 \mathrm{H}$ & $95-04-27$ & $730.66 \mathrm{M}$ \\
\hline $87-09-15$ & $730.65 \mathrm{H}$ & $91-08-15$ & $730.44 \mathrm{H}$ & $95-06-01$ & $730.68 \mathrm{M}$ \\
\hline $87-10-15$ & $730.65 \mathrm{H}$ & $91-09-15$ & $730.46 \mathrm{H}$ & $95-06-27$ & $730.49 \mathrm{M}$ \\
\hline $87-11-15$ & $730.64 \mathrm{H}$ & $91-10-15$ & $730.48 \mathrm{H}$ & & \\
\hline $87-12-15$ & $730.68 \mathrm{H}$ & $91-11-15$ & $730.48 \mathrm{H}$ & & \\
\hline $88-01-15$ & $730.67 \mathrm{H}$ & $91-12-15$ & $730.50 \mathrm{H}$ & & \\
\hline 88-03-15 & $730.78 \mathrm{H}$ & $92-01-15$ & $730.48 \mathrm{H}$ & & \\
\hline $88-04-15$ & $730.83 \mathrm{H}$ & $92-02-15$ & $730.48 \mathrm{H}$ & & \\
\hline $88-05-15$ & $730.73 \mathrm{H}$ & $92-03-15$ & $730.46 \mathrm{H}$ & & \\
\hline $88-06-15$ & $730.73 \mathrm{H}$ & $92-04-15$ & $730.39 \mathrm{H}$ & & \\
\hline $88-07-15$ & $730.76 \mathrm{H}$ & $92-05-15$ & $730.53 \mathrm{H}$ & & \\
\hline $88-09-15$ & $730.35 \mathrm{H}$ & $92-06-15$ & $730.50 \mathrm{H}$ & & \\
\hline $88-10-15$ & $730.33 \mathrm{H}$ & $92-07-15$ & $730.35 \mathrm{H}$ & & \\
\hline $88-11-15$ & $730.33 \mathrm{H}$ & $92-08-15$ & $730.31 \mathrm{H}$ & & \\
\hline $88-12-15$ & $730.32 \mathrm{H}$ & $92-09-15$ & $730.56 \mathrm{H}$ & & \\
\hline $89-01-15$ & $730.34 \mathrm{H}$ & $92-10-15$ & $730.64 \mathrm{H}$ & & \\
\hline
\end{tabular}

${ }^{1}$ Actual date of measurement applies to manual measurements only. For monthly mean water levels, the 15 th of each month was used. This was done to facilitate the plotting of the hydrographs for this report. 


\section{Well J-11}

$[\mathrm{M}$, indicates manual water-level measurement; $\mathrm{H}$, indicates monthly mean water levels averaged from hourly transducer data]

\begin{tabular}{|c|c|c|c|}
\hline $\begin{array}{c}\text { Date }^{1} \\
\text { (year-month-day) }\end{array}$ & $\begin{array}{c}\text { Water-level } \\
\text { altitude } \\
\text { (møters) }\end{array}$ & $\begin{array}{c}\text { Date }^{1} \\
\text { (year-month-day) }\end{array}$ & $\begin{array}{c}\text { Water-level } \\
\text { altitude } \\
\text { (meters) }\end{array}$ \\
\hline $89-01-30$ & $732.17 \mathrm{M}$ & $93-03-04$ & $732.10 \mathrm{M}$ \\
\hline $89-06-12$ & $732.18 \mathrm{M}$ & $93-03-30$ & $732.19 \mathrm{M}$ \\
\hline 89-12-08 & $732.16 \mathrm{M}$ & $93-05-05$ & $732.23 \mathrm{M}$ \\
\hline $90-02-12$ & $732.25 \mathrm{M}$ & 93-06-01 & $732.23 \mathrm{M}$ \\
\hline $90-07-10$ & $732.14 \mathrm{M}$ & $93-06-21$ & $732.22 \mathrm{M}$ \\
\hline $90-07-20$ & $732.20 \mathrm{M}$ & $93-12-01$ & $732.15 \mathrm{M}$ \\
\hline $90-07-27$ & $732.16 \mathrm{M}$ & $93-12-15$ & $732.33 \mathrm{M}$ \\
\hline $90-07-31$ & $732.19 \mathrm{M}$ & $94-02-03$ & $732.24 \mathrm{M}$ \\
\hline $90-08-09$ & $732.17 \mathrm{M}$ & 94-03-01 & $732.13 \mathrm{M}$ \\
\hline $90-08-15$ & $732.22 \mathrm{M}$ & $94-03-15$ & $732.23 \mathrm{M}$ \\
\hline $90-08-21$ & $732.17 \mathrm{M}$ & 94-05-02 & $732.21 \mathrm{M}$ \\
\hline $90-08-27$ & $732.15 \mathrm{M}$ & $94-05-27$ & $732.23 \mathrm{M}$ \\
\hline $90-09-14$ & $732.21 \mathrm{M}$ & $94-06-24$ & $732.21 \mathrm{M}$ \\
\hline $90-10-19$ & $732.25 \mathrm{M}$ & $94-07-27$ & $732.24 \mathrm{M}$ \\
\hline $90-11-19$ & $732.31 \mathrm{M}$ & $94-09-06$ & $732.19 \mathrm{M}$ \\
\hline $90-12-13$ & $732.29 \mathrm{M}$ & $94-09-30$ & $732.28 \mathrm{M}$ \\
\hline $91-01-24$ & $732.23 \mathrm{M}$ & $94-10-27$ & $732.17 \mathrm{M}$ \\
\hline $91-02-28$ & $732.40 \mathrm{M}$ & $94-12-02$ & $732.28 \mathrm{M}$ \\
\hline $91-03-27$ & $732.23 \mathrm{M}$ & $94-12-08$ & $732.14 \mathrm{M}$ \\
\hline $91-04-19$ & $732.19 \mathrm{M}$ & $95-01-13$ & $732.20 \mathrm{M}$ \\
\hline $91-05-07$ & $732.18 \mathrm{M}$ & $95-02-10$ & $732.26 \mathrm{M}$ \\
\hline $91-06-10$ & $732.17 \mathrm{M}$ & 95-03-09 & $732.28 \mathrm{M}$ \\
\hline $91-07-23$ & $732.18 \mathrm{M}$ & $95-04-05$ & $732.28 \mathrm{M}$ \\
\hline $91-08-22$ & $732.18 \mathrm{M}$ & $95-05-08$ & $732.23 \mathrm{M}$ \\
\hline $91-09-16$ & $732.14 \mathrm{M}$ & $95-06-06$ & $732.27 \mathrm{M}$ \\
\hline $91-10-31$ & $732.09 \mathrm{M}$ & $95-07-13$ & $732.25 \mathrm{M}$ \\
\hline $91-11-26$ & $732.21 \mathrm{M}$ & $95-07-24$ & $732.25 \mathrm{M}$ \\
\hline $91-12-16$ & $732.17 \mathrm{M}$ & $95-08-29$ & $732.29 \mathrm{M}$ \\
\hline $92-01-31$ & $732.18 \mathrm{M}$ & $95-09-14$ & $732.24 \mathrm{M}$ \\
\hline $92-02-20$ & $732.16 \mathrm{M}$ & $95-12-04$ & $732.24 \mathrm{M}$ \\
\hline $92-04-06$ & $732.17 \mathrm{M}$ & & \\
\hline $92-05-04$ & $732.19 \mathrm{M}$ & & \\
\hline $92-05-21$ & $732.21 \mathrm{M}$ & & \\
\hline $92-06-17$ & $732.19 \mathrm{M}$ & & \\
\hline $92-07-16$ & $732.20 \mathrm{M}$ & & \\
\hline $92-08-19$ & $732.20 \mathrm{M}$ & & \\
\hline $92-09-11$ & $732.20 \mathrm{M}$ & & \\
\hline $92-10-30$ & $732.30 \mathrm{M}$ & & \\
\hline $92-11-25$ & $732.12 \mathrm{M}$ & & \\
\hline $92-12-17$ & $732.25 \mathrm{M}$ & & \\
\hline $93-02-02$ & $732.20 \mathrm{M}$ & & \\
\hline
\end{tabular}

${ }^{1}$ Actual date of measurement applies to manual measurements only. For monthly mean water levels, the 15 th of each month was used. This was done to facilitate the plotting of the hydrographs for this report. 
Well J-12

[M, indicates manual water-level measurement; $\mathrm{H}$, indicates monthly mean water levels averaged from hourly transducer data]

\begin{tabular}{|c|c|c|c|c|c|}
\hline $\begin{array}{c}\text { Date }^{1} \\
\text { (year-month-day) }\end{array}$ & $\begin{array}{c}\text { Water-level } \\
\text { altitude } \\
\text { (meters) }\end{array}$ & $\begin{array}{c}\text { Date }^{1} \\
\text { (year-month-day) }\end{array}$ & $\begin{array}{c}\text { Water-level } \\
\text { altitude } \\
\text { (meters) }\end{array}$ & $\begin{array}{c}\text { Date }^{1} \\
\text { (year-month-day) }\end{array}$ & $\begin{array}{l}\text { Water-level } \\
\text { altitude } \\
\text { (meters) }\end{array}$ \\
\hline $89-08-28$ & $728.00 \mathrm{M}$ & $93-02-01$ & $727.99 \mathrm{M}$ & $95-02-10$ & $727.94 \mathrm{M}$ \\
\hline $89-10-02$ & $728.03 \mathrm{M}$ & $93-02-08$ & $728.15 \mathrm{M}$ & $95-02-24$ & $727.88 \mathrm{M}$ \\
\hline $89-11-16$ & $727.94 \mathrm{M}$ & $93-03-01$ & $727.94 \mathrm{M}$ & 95-03-09 & $727.92 \mathrm{M}$ \\
\hline $89-12-22$ & $727.84 \mathrm{M}$ & $93-03-08$ & $727.98 \mathrm{M}$ & $95-03-24$ & $727.94 \mathrm{M}$ \\
\hline $90-01-25$ & $727.89 \mathrm{M}$ & $93-03-30$ & $727.95 \mathrm{M}$ & $95-04-05$ & $727.93 \mathrm{M}$ \\
\hline $90-02-08$ & $727.91 \mathrm{M}$ & $93-03-31$ & $727.95 \mathrm{M}$ & $95-04-24$ & $727.88 \mathrm{M}$ \\
\hline 90-03-09 & $727.99 \mathrm{M}$ & $93-04-12$ & $727.99 \mathrm{M}$ & $95-05-08$ & $727.86 \mathrm{M}$ \\
\hline $90-04-17$ & $727.98 \mathrm{M}$ & $93-04-28$ & $727.95 \mathrm{M}$ & $95-05-18$ & $727.84 \mathrm{M}$ \\
\hline $90-05-30$ & $727.95 \mathrm{M}$ & $93-05-11$ & $728.03 \mathrm{M}$ & $95-06-06$ & $727.91 \mathrm{M}$ \\
\hline $90-06-18$ & $727.89 \mathrm{M}$ & $93-06-01$ & $727.99 \mathrm{M}$ & $95-06-21$ & $727.84 \mathrm{M}$ \\
\hline $90-07-10$ & $727.90 \mathrm{M}$ & $93-06-11$ & $727.99 \mathrm{M}$ & $95-07-10$ & $727.87 \mathrm{M}$ \\
\hline $90-08-20$ & $727.94 \mathrm{M}$ & $93-06-29$ & $727.99 \mathrm{M}$ & $95-07-31$ & $727.92 \mathrm{M}$ \\
\hline $90-09-14$ & $727.94 \mathrm{M}$ & $93-11-08$ & $727.92 \mathrm{M}$ & $95-08-15$ & $727.89 \mathrm{M}$ \\
\hline $90-10-29$ & $727.98 \mathrm{M}$ & $93-12-01$ & $727.84 \mathrm{M}$ & $95-08-30$ & $727.94 \mathrm{M}$ \\
\hline $90-11-27$ & $727.90 \mathrm{M}$ & $93-12-10$ & $727.92 \mathrm{M}$ & $95-09-14$ & $727.91 \mathrm{M}$ \\
\hline $90-12-13$ & $727.99 \mathrm{M}$ & $93-12-30$ & $727.93 \mathrm{M}$ & $95-12-04$ & $727.89 \mathrm{M}$ \\
\hline $91-02-25$ & $727.88 \mathrm{M}$ & $94-01-14$ & $727.99 \mathrm{M}$ & & \\
\hline $91-04-24$ & $727.94 \mathrm{M}$ & $94-02-02$ & $727.98 \mathrm{M}$ & & \\
\hline $91-05-14$ & $727.96 \mathrm{M}$ & $94-02-10$ & $727.94 \mathrm{M}$ & & \\
\hline $91-06-10$ & $727.94 \mathrm{M}$ & 94-03-01 & $727.85 \mathrm{M}$ & & \\
\hline $91-07-23$ & $727.92 \mathrm{M}$ & $94-03-10$ & $727.95 \mathrm{M}$ & & \\
\hline $91-08-21$ & $727.93 \mathrm{M}$ & $94-03-24$ & $727.95 \mathrm{M}$ & & \\
\hline $91-09-12$ & $727.94 \mathrm{M}$ & $94-04-15$ & $727.86 \mathrm{M}$ & & \\
\hline $91-10-25$ & $727.97 \mathrm{M}$ & $94-04-29$ & $727.85 \mathrm{M}$ & & \\
\hline $91-11-21$ & $727.98 \mathrm{M}$ & $94-05-05$ & $727.96 \mathrm{M}$ & & \\
\hline $91-12-17$ & $728.01 \mathrm{M}$ & $94-05-16$ & $728.00 \mathrm{M}$ & & \\
\hline $92-05-22$ & $727.93 \mathrm{M}$ & $94-05-27$ & $727.92 \mathrm{M}$ & & \\
\hline $92-06-04$ & $727.98 \mathrm{M}$ & $94-06-10$ & $727.92 \mathrm{M}$ & & \\
\hline $92-06-17$ & $727.95 \mathrm{M}$ & $94-06-24$ & $727.92 \mathrm{M}$ & & \\
\hline $92-07-16$ & $727.94 \mathrm{M}$ & $94-07-08$ & $727.89 \mathrm{M}$ & & \\
\hline $92-07-28$ & $727.95 \mathrm{M}$ & $94-07-28$ & $727.89 \mathrm{M}$ & & \\
\hline $92-08-18$ & $727.96 \mathrm{M}$ & $94-08-05$ & $727.93 \mathrm{M}$ & & \\
\hline $92-08-31$ & $727.99 \mathrm{M}$ & $94-08-31$ & $727.89 \mathrm{M}$ & & \\
\hline $92-09-11$ & $727.95 \mathrm{M}$ & $94-09-16$ & $727.87 \mathrm{M}$ & & \\
\hline $92-09-28$ & $727.95 \mathrm{M}$ & $94-09-30$ & $727.92 \mathrm{M}$ & & \\
\hline $92-10-15$ & $727.94 \mathrm{M}$ & $94-10-11$ & $727.90 \mathrm{M}$ & & \\
\hline $92-10-29$ & $728.03 \mathrm{M}$ & $94-10-27$ & $727.84 \mathrm{M}$ & & \\
\hline $92-11-19$ & $727.96 \mathrm{M}$ & $94-11-29$ & $727.81 \mathrm{M}$ & & \\
\hline $92-11-30$ & $727.92 \mathrm{M}$ & $94-12-13$ & $727.92 \mathrm{M}$ & & \\
\hline $92-12-08$ & $727.99 \mathrm{M}$ & $94-12-29$ & $727.95 \mathrm{M}$ & & \\
\hline $92-12-17$ & $728.02 \mathrm{M}$ & $95-01-12$ & $727.88 \mathrm{M}$ & & \\
\hline $93-01-19$ & $727.94 \mathrm{M}$ & $95-01-26$ & $727.89 \mathrm{M}$ & & \\
\hline
\end{tabular}

${ }^{1}$ Actual date of measurement applies to manual measurements only. For monthly mean water levels, the 15 th of each month was used. This was done to facilitate the plotting of the hydrographs for this report. 
Well J-13

[M, indicates manual water-level measurement; $\mathrm{H}$, indicates monthly mean water levels averaged from hourly transducer data]

\begin{tabular}{|c|c|c|c|c|c|}
\hline $\begin{array}{c}\text { Date }^{1} \\
\text { (year-month-day) }\end{array}$ & $\begin{array}{c}\text { Water-level } \\
\text { altitude } \\
\text { (meters) }\end{array}$ & $\begin{array}{c}\text { Date }^{1} \\
\text { (year-month-day) }\end{array}$ & $\begin{array}{c}\text { Water-level } \\
\text { altitude } \\
\text { (meters) }\end{array}$ & $\begin{array}{c}\text { Date }^{1} \\
\text { (year-month-day) }\end{array}$ & $\begin{array}{l}\text { Water-level } \\
\text { altitude } \\
\text { (meters) }\end{array}$ \\
\hline $86-09-09$ & $728.50 \mathrm{M}$ & $92-01-28$ & $728.44 \mathrm{M}$ & $94-03-01$ & $728.35 \mathrm{M}$ \\
\hline $86-09-11$ & $728.39 \mathrm{M}$ & $92-02-20$ & $728.41 \mathrm{M}$ & $94-03-15$ & $728.46 \mathrm{M}$ \\
\hline $87-03-24$ & $728.41 \mathrm{M}$ & $92-02-28$ & $728.41 \mathrm{M}$ & $94-03-24$ & $728.42 \mathrm{M}$ \\
\hline $87-05-08$ & $728.33 \mathrm{M}$ & $92-03-11$ & $728.40 \mathrm{M}$ & $94-04-15$ & $728.36 \mathrm{M}$ \\
\hline $87-12-09$ & $728.41 \mathrm{M}$ & $92-04-03$ & $728.43 \mathrm{M}$ & $94-04-29$ & $728.34 \mathrm{M}$ \\
\hline $87-12-31$ & $728.40 \mathrm{M}$ & $92-04-10$ & $728.46 \mathrm{M}$ & $94-05-18$ & $728.37 \mathrm{M}$ \\
\hline $88-03-04$ & $728.39 \mathrm{M}$ & $92-05-04$ & $728.40 \mathrm{M}$ & $94-05-27$ & $728.41 \mathrm{M}$ \\
\hline $88-04-21$ & $728.50 \mathrm{M}$ & $92-05-13$ & $728.44 \mathrm{M}$ & $94-06-10$ & $728.41 \mathrm{M}$ \\
\hline 88-07-07 & $728.38 \mathrm{M}$ & $92-05-22$ & $728.36 \mathrm{M}$ & $94-06-24$ & $728.39 \mathrm{M}$ \\
\hline $88-10-26$ & $728.51 \mathrm{M}$ & $92-06-04$ & $728.44 \mathrm{M}$ & $94-07-08$ & $728.37 \mathrm{M}$ \\
\hline $89-01-18$ & $728.45 \mathrm{M}$ & $92-06-17$ & $728.40 \mathrm{M}$ & $94-07-27$ & $728.39 \mathrm{M}$ \\
\hline $89-02-22$ & $728.40 \mathrm{M}$ & $92-07-14$ & $728.44 \mathrm{M}$ & $94-08-05$ & $728.36 \mathrm{M}$ \\
\hline $89-03-22$ & $728.49 \mathrm{M}$ & $92-07-28$ & $728.45 \mathrm{M}$ & $94-08-31$ & $728.41 \mathrm{M}$ \\
\hline $89-05-30$ & $728.41 \mathrm{M}$ & $92-08-18$ & $728.45 \mathrm{M}$ & $94-09-16$ & $728.31 \mathrm{M}$ \\
\hline $89-07-21$ & $728.48 \mathrm{M}$ & $92-08-31$ & $728.50 \mathrm{M}$ & $94-09-30$ & $728.46 \mathrm{M}$ \\
\hline $89-08-14$ & $728.48 \mathrm{M}$ & $92-09-11$ & $728.48 \mathrm{M}$ & $94-10-12$ & $728.39 \mathrm{M}$ \\
\hline $89-11-21$ & $728.48 \mathrm{M}$ & $92-09-29$ & $728.46 \mathrm{M}$ & $94-10-27$ & $728.35 \mathrm{M}$ \\
\hline $89-12-20$ & $728.44 \mathrm{M}$ & $92-10-15$ & $728.48 \mathrm{M}$ & $94-11-10$ & $728.48 \mathrm{M}$ \\
\hline $90-01-25$ & $728.38 \mathrm{M}$ & $92-10-29$ & $728.61 \mathrm{M}$ & $94-11-29$ & $728.30 \mathrm{M}$ \\
\hline $90-02-09$ & $728.39 \mathrm{M}$ & $92-11-19$ & $728.55 \mathrm{M}$ & $94-12-13$ & $728.41 \mathrm{M}$ \\
\hline $90-03-09$ & $728.51 \mathrm{M}$ & $92-11-30$ & $728.45 \mathrm{M}$ & $94-12-29$ & $728.48 \mathrm{M}$ \\
\hline $90-04-20$ & $728.44 \mathrm{M}$ & $92-12-08$ & $728.55 \mathrm{M}$ & $95-01-12$ & $728.41 \mathrm{M}$ \\
\hline $90-05-23$ & $728.48 \mathrm{M}$ & $92-12-17$ & $728.54 \mathrm{M}$ & $95-01-26$ & $728.42 \mathrm{M}$ \\
\hline $90-06-20$ & $728.44 \mathrm{M}$ & $93-01-19$ & $728.48 \mathrm{M}$ & $95-02-10$ & $728.48 \mathrm{M}$ \\
\hline $90-07-10$ & $728.39 \mathrm{M}$ & $93-02-01$ & $728.45 \mathrm{M}$ & $95-02-24$ & $728.38 \mathrm{M}$ \\
\hline $90-08-15$ & $728.50 \mathrm{M}$ & $93-02-08$ & $728.69 \mathrm{M}$ & $95-03-09$ & $728.43 \mathrm{M}$ \\
\hline $90-09-14$ & $728.46 \mathrm{M}$ & $93-03-01$ & $728.46 \mathrm{M}$ & $95-03-24$ & $728.44 \mathrm{M}$ \\
\hline $90-10-29$ & $728.51 \mathrm{M}$ & $93-03-15$ & $728.48 \mathrm{M}$ & $95-04-05$ & $728.46 \mathrm{M}$ \\
\hline $90-11-27$ & $728.42 \mathrm{M}$ & $93-03-30$ & $728.47 \mathrm{M}$ & $95-04-24$ & $728.40 \mathrm{M}$ \\
\hline $90-12-13$ & $728.38 \mathrm{M}$ & $93-04-21$ & $728.42 \mathrm{M}$ & $95-05-08$ & $728.39 \mathrm{M}$ \\
\hline $91-01-31$ & $728.40 \mathrm{M}$ & $93-04-28$ & $728.39 \mathrm{M}$ & $95-05-18$ & $728.59 \mathrm{M}$ \\
\hline $91-02-25$ & $728.41 \mathrm{M}$ & $93-05-14$ & $728.44 \mathrm{M}$ & $95-06-06$ & $728.59 \mathrm{M}$ \\
\hline $91-03-27$ & $728.48 \mathrm{M}$ & $93-06-01$ & $728.50 \mathrm{M}$ & $95-06-29$ & $728.43 \mathrm{M}$ \\
\hline $91-04-24$ & $728.68 \mathrm{M}$ & $93-06-11$ & $728.49 \mathrm{M}$ & $95-07-12$ & $728.39 \mathrm{M}$ \\
\hline $91-05-16$ & $728.50 \mathrm{M}$ & $93-06-29$ & $728.50 \mathrm{M}$ & $95-07-31$ & $728.36 \mathrm{M}$ \\
\hline $91-06-10$ & $728.45 \mathrm{M}$ & $93-11-08$ & $728.42 \mathrm{M}$ & $95-08-15$ & $728.34 \mathrm{M}$ \\
\hline $91-07-25$ & $728.49 \mathrm{M}$ & $93-12-01$ & $728.38 \mathrm{M}$ & $95-12-12$ & $728.43 \mathrm{M}$ \\
\hline $91-08-22$ & $728.42 \mathrm{M}$ & $93-12-10$ & $728.44 \mathrm{M}$ & & \\
\hline $91-09-16$ & $728.39 \mathrm{M}$ & $93-12-30$ & $728.44 \mathrm{M}$ & & \\
\hline $91-10-25$ & $728.50 \mathrm{M}$ & $94-01-14$ & $728.41 \mathrm{M}$ & & \\
\hline $91-11-21$ & $728.48 \mathrm{M}$ & $94-02-02$ & $728.44 \mathrm{M}$ & & \\
\hline $91-12-17$ & $728.50 \mathrm{M}$ & $94-02-10$ & $728.48 \mathrm{M}$ & & \\
\hline
\end{tabular}

${ }^{1}$ Actual date of measurement applies to manual measurements only. For monthly mean water levels, the 15 th of each month was used. This was done to facilitate the plotting of the hydrographs for this report. 


\section{Well USW H-1, Tube 1}

[M, indicates manual water-level measurement; $\mathrm{H}$, indicates monthly mean water levels averaged from hourly transducer data]

\begin{tabular}{|c|c|c|c|c|c|}
\hline $\begin{array}{c}\text { Date }^{1} \\
\text { (year-month-day) }\end{array}$ & $\begin{array}{c}\text { Water-level } \\
\text { altitude } \\
\text { (meters) }\end{array}$ & $\begin{array}{c}\text { Date }^{1} \\
\text { (year-month-day) }\end{array}$ & $\begin{array}{c}\text { Water-level } \\
\text { altitude } \\
\text { (meters) }\end{array}$ & $\begin{array}{c}\text { Date }^{1} \\
\text { (year-month-day) }\end{array}$ & $\begin{array}{l}\text { Water-level } \\
\text { altitude } \\
\text { (meters) }\end{array}$ \\
\hline $85-02-13$ & $785.09 \mathrm{M}$ & $90-08-15$ & $785.43 \mathrm{H}$ & $94-06-23$ & $785.78 \mathrm{M}$ \\
\hline $85-08-20$ & $785.21 \mathrm{M}$ & $90-09-15$ & $785.44 \mathrm{H}$ & $94-07-27$ & $785.78 \mathrm{M}$ \\
\hline $85-08-23$ & $785.21 \mathrm{M}$ & $90-10-15$ & $785.45 \mathrm{H}$ & $94-08-18$ & $785.88 \mathrm{M}$ \\
\hline $85-10-15$ & $785.19 \mathrm{H}$ & $90-11-15$ & $785.47 \mathrm{H}$ & $94-09-27$ & $785.83 \mathrm{M}$ \\
\hline $85-11-15$ & $785.21 \mathrm{H}$ & $90-12-15$ & $785.47 \mathrm{H}$ & $94-10-19$ & $785.89 \mathrm{M}$ \\
\hline $86-04-15$ & $785.26 \mathrm{H}$ & $91-01-15$ & $785.47 \mathrm{H}$ & $94-11-09$ & $785.85 \mathrm{M}$ \\
\hline $86-05-15$ & $785.26 \mathrm{H}$ & $91-02-15$ & $785.49 \mathrm{H}$ & $94-12-27$ & $785.73 \mathrm{M}$ \\
\hline $86-06-15$ & $785.27 \mathrm{H}$ & $91-03-15$ & $785.55 \mathrm{H}$ & $95-01-26$ & $785.86 \mathrm{M}$ \\
\hline $86-07-15$ & $785.30 \mathrm{H}$ & $91-04-15$ & $785.61 \mathrm{H}$ & $95-03-02$ & $785.94 \mathrm{M}$ \\
\hline $86-08-15$ & $785.27 \mathrm{H}$ & $91-05-15$ & $785.62 \mathrm{H}$ & $95-03-24$ & $785.95 \mathrm{M}$ \\
\hline $86-09-15$ & $785.28 \mathrm{H}$ & $91-06-15$ & $785.61 \mathrm{H}$ & $95-04-11$ & $786.01 \mathrm{M}$ \\
\hline $86-10-15$ & $785.26 \mathrm{H}$ & $91-07-15$ & $785.60 \mathrm{H}$ & $95-05-04$ & $786.05 \mathrm{M}$ \\
\hline $86-11-15$ & $785.20 \mathrm{H}$ & $91-08-15$ & $785.61 \mathrm{H}$ & $95-06-13$ & $786.02 \mathrm{M}$ \\
\hline $86-12-15$ & $785.10 \mathrm{H}$ & $91-09-15$ & $785.61 \mathrm{H}$ & $95-07-12$ & $785.99 \mathrm{M}$ \\
\hline $87-01-15$ & $785.19 \mathrm{H}$ & $91-10-15$ & $785.60 \mathrm{H}$ & $95-08-16$ & $786.00 \mathrm{M}$ \\
\hline $87-02-15$ & $785.23 \mathrm{H}$ & $91-11-15$ & $785.59 \mathrm{H}$ & $95-09-14$ & $786.01 \mathrm{M}$ \\
\hline $87-03-15$ & $785.29 \mathrm{H}$ & $91-12-15$ & $785.63 \mathrm{H}$ & $95-12-05$ & $785.91 \mathrm{M}$ \\
\hline $87-04-15$ & $785.27 \mathrm{H}$ & $92-01-15$ & $785.66 \mathrm{H}$ & & \\
\hline $87-05-15$ & $785.26 \mathrm{H}$ & $92-02-15$ & $785.67 \mathrm{H}$ & & \\
\hline $87-06-15$ & $785.20 \mathrm{H}$ & $92-03-15$ & $785.73 \mathrm{H}$ & & \\
\hline $87-07-15$ & $785.19 \mathrm{H}$ & $92-04-15$ & $785.73 \mathrm{H}$ & & \\
\hline $87-09-15$ & $785.19 \mathrm{H}$ & $92-05-15$ & $785.70 \mathrm{H}$ & & \\
\hline $87-10-15$ & $785.16 \mathrm{H}$ & $92-06-15$ & $785.70 \mathrm{H}$ & & \\
\hline $87-11-15$ & $785.22 \mathrm{H}$ & $92-07-15$ & $785.76 \mathrm{H}$ & & \\
\hline 88-04-06 & $785.10 \mathrm{M}$ & $92-08-15$ & $785.74 \mathrm{H}$ & & \\
\hline $88-08-22$ & $785.15 \mathrm{M}$ & $92-09-15$ & $785.51 \mathrm{H}$ & & \\
\hline $88-11-22$ & $785.00 \mathrm{M}$ & $92-10-15$ & $785.50 \mathrm{H}$ & & \\
\hline $89-03-15$ & $785.04 \mathrm{H}$ & $92-11-24$ & $785.48 \mathrm{M}$ & & \\
\hline 89-04-15 & $785.06 \mathrm{H}$ & $92-12-15$ & $785.43 \mathrm{M}$ & & \\
\hline $89-05-15$ & $785.11 \mathrm{H}$ & $93-01-21$ & $785.49 \mathrm{M}$ & & \\
\hline $89-06-15$ & $785.15 \mathrm{H}$ & $93-02-17$ & $785.51 \mathrm{M}$ & & \\
\hline $89-07-15$ & $785.15 \mathrm{H}$ & $93-03-24$ & $785.50 \mathrm{M}$ & & \\
\hline $89-10-15$ & $785.38 \mathrm{H}$ & $93-04-21$ & $785.55 \mathrm{M}$ & & \\
\hline $89-11-15$ & $785.35 \mathrm{H}$ & $93-05-13$ & $785.64 \mathrm{M}$ & & \\
\hline $89-12-15$ & $785.29 \mathrm{H}$ & $93-06-24$ & $785.56 \mathrm{M}$ & & \\
\hline $90-01-15$ & $785.23 \mathrm{H}$ & $93-11-19$ & $785.70 \mathrm{M}$ & & \\
\hline $90-02-15$ & $785.20 \mathrm{H}$ & $93-12-13$ & $785.67 \mathrm{M}$ & & \\
\hline $90-03-15$ & $785.18 \mathrm{H}$ & $94-01-31$ & $785.60 \mathrm{M}$ & & \\
\hline $90-04-15$ & $785.23 \mathrm{H}$ & $94-02-28$ & $785.62 \mathrm{M}$ & & \\
\hline $90-05-15$ & $785.37 \mathrm{H}$ & $94-03-15$ & $785.59 \mathrm{M}$ & & \\
\hline $90-06-15$ & $785.45 \mathrm{H}$ & $94-04-21$ & $785.71 \mathrm{M}$ & & \\
\hline $90-07-15$ & $785.45 \mathrm{H}$ & $94-05-12$ & $785.67 \mathrm{M}$ & & \\
\hline
\end{tabular}

${ }^{1}$ Actual date of measurement applies to manual measurements only. For monthly mean water levels, the 15 th of each month was used. This was done to facilitate the plotting of the hydrographs for this report. 


\section{Well USW H-1, Tube 2}

[M, indicates manual water-level measurement; $\mathrm{H}$, indicates monthly mean water levels averaged from hourly transducer data]

\begin{tabular}{|c|c|c|c|}
\hline $\begin{array}{c}\text { Date }^{1} \\
\text { (year-month-day) }\end{array}$ & $\begin{array}{l}\text { Water-level } \\
\text { altitude } \\
\text { (meters) }\end{array}$ & $\begin{array}{c}\text { Date }^{1} \\
\text { (year-month-day) }\end{array}$ & $\begin{array}{l}\text { Water-level } \\
\text { altitude } \\
\text { (meters) }\end{array}$ \\
\hline $85-08-26$ & $736.26 \mathrm{M}$ & $92-11-15$ & $735.97 \mathrm{H}$ \\
\hline $85-08-27$ & $736.26 \mathrm{M}$ & $92-12-15$ & $735.97 \mathrm{H}$ \\
\hline $87-09-11$ & $736.28 \mathrm{M}$ & $93-01-15$ & $735.93 \mathrm{H}$ \\
\hline 88-04-07 & $736.19 \mathrm{M}$ & $93-02-15$ & $735.92 \mathrm{H}$ \\
\hline $88-08-22$ & $736.23 \mathrm{M}$ & $93-03-15$ & $735.93 \mathrm{H}$ \\
\hline $88-11-25$ & $735.92 \mathrm{M}$ & $93-04-15$ & $735.90 \mathrm{H}$ \\
\hline $89-01-15$ & $735.90 \mathrm{H}$ & $93-05-15$ & $735.87 \mathrm{H}$ \\
\hline $89-02-15$ & $735.89 \mathrm{H}$ & $93-06-24$ & $736.06 \mathrm{M}$ \\
\hline 89-03-15 & $735.89 \mathrm{H}$ & $93-11-19$ & $735.87 \mathrm{M}$ \\
\hline 89-04-15 & $735.89 \mathrm{H}$ & $93-12-13$ & $736.04 \mathrm{M}$ \\
\hline $89-05-15$ & $735.89 \mathrm{H}$ & $94-01-31$ & $735.84 \mathrm{M}$ \\
\hline $89-06-15$ & $735.89 \mathrm{H}$ & $94-02-28$ & $736.01 \mathrm{M}$ \\
\hline $89-07-15$ & $735.88 \mathrm{H}$ & $94-03-15$ & $736.02 \mathrm{M}$ \\
\hline $89-10-15$ & $736.25 \mathrm{H}$ & $94-04-21$ & $736.01 \mathrm{M}$ \\
\hline $89-12-15$ & $736.20 \mathrm{H}$ & $94-05-12$ & $735.90 \mathrm{M}$ \\
\hline $90-01-15$ & $736.19 \mathrm{H}$ & $94-06-23$ & $735.82 \mathrm{M}$ \\
\hline $90-02-15$ & $736.14 \mathrm{H}$ & $94-07-27$ & $735.80 \mathrm{M}$ \\
\hline $90-03-15$ & $736.13 \mathrm{H}$ & $94-07-28$ & $735.81 \mathrm{M}$ \\
\hline $90-04-15$ & $736.13 \mathrm{H}$ & $94-08-01$ & $735.82 \mathrm{M}$ \\
\hline $90-05-15$ & $736.14 \mathrm{H}$ & $94-08-18$ & $735.80 \mathrm{M}$ \\
\hline $90-06-15$ & $736.15 \mathrm{H}$ & $94-09-27$ & $735.77 \mathrm{M}$ \\
\hline $90-07-15$ & $736.15 \mathrm{H}$ & $94-11-09$ & $735.78 \mathrm{M}$ \\
\hline $90-08-15$ & $736.16 \mathrm{H}$ & $94-12-27$ & $735.75 \mathrm{M}$ \\
\hline $90-09-15$ & $736.16 \mathrm{H}$ & $95-01-26$ & $735.70 \mathrm{M}$ \\
\hline $90-10-15$ & $736.16 \mathrm{H}$ & $95-03-02$ & $735.74 \mathrm{M}$ \\
\hline $90-11-15$ & $736.17 \mathrm{H}$ & $95-03-24$ & $735.74 \mathrm{M}$ \\
\hline $90-12-15$ & $736.17 \mathrm{H}$ & $95-04-11$ & $735.78 \mathrm{M}$ \\
\hline $91-01-15$ & $736.16 \mathrm{H}$ & $95-05-04$ & $735.78 \mathrm{M}$ \\
\hline $91-04-11$ & $736.03 \mathrm{M}$ & $95-06-13$ & $735.71 \mathrm{M}$ \\
\hline $91-10-24$ & $736.09 \mathrm{M}$ & $95-07-12$ & $735.77 \mathrm{M}$ \\
\hline $91-11-15$ & $736.07 \mathrm{H}$ & $95-08-16$ & $735.77 \mathrm{M}$ \\
\hline $91-12-15$ & $736.05 \mathrm{H}$ & $95-09-14$ & $735.76 \mathrm{M}$ \\
\hline $92-01-15$ & $736.03 \mathrm{H}$ & $95-12-05$ & $735.67 \mathrm{M}$ \\
\hline $92-02-15$ & $736.02 \mathrm{H}$ & & \\
\hline $92-03-15$ & $736.01 \mathrm{H}$ & & \\
\hline $92-04-15$ & $736.00 \mathrm{H}$ & & \\
\hline $92-05-15$ & $735.97 \mathrm{H}$ & & \\
\hline $92-06-15$ & $735.95 \mathrm{H}$ & & \\
\hline $92-07-15$ & $735.95 \mathrm{H}$ & & \\
\hline $92-08-15$ & $735.95 \mathrm{H}$ & & \\
\hline $92-09-15$ & $735.94 \mathrm{H}$ & & \\
\hline $92-10-15$ & $735.96 \mathrm{H}$ & & \\
\hline
\end{tabular}

${ }^{1}$ Actual date of measurement applies to manual measurements only. For monthly mean water levels, the 15 th of each month was used. This was done to facilitate the plotting of the hydrographs for this report. 


\section{Well USW H-1, Tube 3}

[M, indicates manual water-level measurement; $\mathrm{H}$, indicates monthly mean water levels averaged from hourly transducer data]

\begin{tabular}{|c|c|c|c|c|c|}
\hline $\begin{array}{c}\text { Date }^{1} \\
\text { (year-month-day) }\end{array}$ & $\begin{array}{l}\text { Water-level } \\
\text { altitude } \\
\text { (meters) }\end{array}$ & $\begin{array}{c}\text { Date }^{1} \\
\text { (year-month-day) }\end{array}$ & $\begin{array}{l}\text { Water-level } \\
\text { altitude } \\
\text { (meters) }\end{array}$ & $\begin{array}{c}\text { Date }^{1} \\
\text { (year-month-day) }\end{array}$ & $\begin{array}{c}\text { Water-level } \\
\text { altitude } \\
\text { (meters) }\end{array}$ \\
\hline $85-02-15$ & $730.63 \mathrm{H}$ & $89-10-15$ & $730.53 \mathrm{H}$ & $93-11-15$ & $730.68 \mathrm{H}$ \\
\hline $85-03-15$ & $730.69 \mathrm{H}$ & $89-11-15$ & $730.52 \mathrm{H}$ & $93-12-15$ & $730.72 \mathrm{H}$ \\
\hline $85-04-15$ & $730.60 \mathrm{H}$ & $89-12-15$ & $730.52 \mathrm{H}$ & $94-01-15$ & $730.72 \mathrm{H}$ \\
\hline $85-05-15$ & $730.77 \mathrm{H}$ & $90-01-15$ & $730.50 \mathrm{H}$ & $94-02-15$ & $730.68 \mathrm{H}$ \\
\hline $85-06-15$ & $730.81 \mathrm{H}$ & $90-02-15$ & $730.50 \mathrm{H}$ & $94-03-15$ & $730.56 \mathrm{H}$ \\
\hline $85-07-15$ & $730.69 \mathrm{H}$ & $90-03-15$ & $730.54 \mathrm{H}$ & $94-04-15$ & $730.56 \mathrm{H}$ \\
\hline $86-05-15$ & $730.61 \mathrm{H}$ & $90-04-15$ & $730.52 \mathrm{H}$ & $94-05-15$ & $730.55 \mathrm{H}$ \\
\hline $86-06-15$ & $730.60 \mathrm{H}$ & $90-05-15$ & $730.49 \mathrm{H}$ & $94-06-15$ & $730.54 \mathrm{H}$ \\
\hline $86-07-15$ & $730.59 \mathrm{H}$ & $90-06-15$ & $730.48 \mathrm{H}$ & $94-07-15$ & $730.55 \mathrm{H}$ \\
\hline $86-08-15$ & $730.64 \mathrm{H}$ & $90-07-15$ & $730.48 \mathrm{H}$ & $94-08-15$ & $730.54 \mathrm{H}$ \\
\hline $86-09-15$ & $730.66 \mathrm{H}$ & $90-08-15$ & $730.47 \mathrm{H}$ & $94-09-15$ & $730.54 \mathrm{H}$ \\
\hline $86-10-15$ & $730.63 \mathrm{H}$ & $90-09-15$ & $730.46 \mathrm{H}$ & $94-10-15$ & $730.54 \mathrm{H}$ \\
\hline $86-11-15$ & $730.64 \mathrm{H}$ & $90-10-15$ & $730.46 \mathrm{H}$ & $94-11-15$ & $730.59 \mathrm{H}$ \\
\hline $86-12-15$ & $730.65 \mathrm{H}$ & $90-11-15$ & $730.46 \mathrm{H}$ & $94-12-15$ & $730.63 \mathrm{H}$ \\
\hline $87-01-15$ & $730.67 \mathrm{H}$ & $90-12-15$ & $730.52 \mathrm{H}$ & $95-01-15$ & $730.61 \mathrm{H}$ \\
\hline $87-02-15$ & $730.68 \mathrm{H}$ & $91-01-15$ & $730.50 \mathrm{H}$ & $95-02-15$ & $730.62 \mathrm{H}$ \\
\hline $87-03-15$ & $730.68 \mathrm{H}$ & $91-09-15$ & $730.74 \mathrm{H}$ & $95-03-15$ & $730.63 \mathrm{H}$ \\
\hline $87-04-15$ & $730.67 \mathrm{H}$ & $91-10-15$ & $730.77 \mathrm{H}$ & $95-04-15$ & $730.62 \mathrm{H}$ \\
\hline $87-05-15$ & $730.69 \mathrm{H}$ & $91-11-15$ & $730.75 \mathrm{H}$ & $95-05-15$ & $730.67 \mathrm{H}$ \\
\hline $87-06-15$ & $730.66 \mathrm{H}$ & $91-12-15$ & $730.75 \mathrm{H}$ & $95-06-15$ & $730.62 \mathrm{H}$ \\
\hline $87-07-15$ & $730.68 \mathrm{H}$ & $92-01-15$ & $730.73 \mathrm{H}$ & $95-07-15$ & $730.62 \mathrm{H}$ \\
\hline $87-08-15$ & $730.61 \mathrm{H}$ & $92-02-15$ & $730.77 \mathrm{H}$ & $95-08-15$ & $730.64 \mathrm{H}$ \\
\hline $87-09-15$ & $730.61 \mathrm{H}$ & $92-03-15$ & $730.78 \mathrm{H}$ & $95-09-15$ & $730.72 \mathrm{H}$ \\
\hline $87-10-15$ & $730.66 \mathrm{H}$ & $92-04-15$ & $730.76 \mathrm{H}$ & $95-12-05$ & $730.69 \mathrm{M}$ \\
\hline $88-04-15$ & $730.58 \mathrm{H}$ & $92-05-15$ & $730.77 \mathrm{H}$ & & \\
\hline $88-05-15$ & $730.58 \mathrm{H}$ & $92-06-15$ & $730.74 \mathrm{H}$ & & \\
\hline $88-06-15$ & $730.58 \mathrm{H}$ & $92-07-15$ & $730.72 \mathrm{H}$ & & \\
\hline $88-07-15$ & $730.58 \mathrm{H}$ & $92-08-15$ & $730.68 \mathrm{H}$ & & \\
\hline $88-08-15$ & $730.37 \mathrm{H}$ & $92-09-15$ & $730.66 \mathrm{H}$ & & \\
\hline $88-09-15$ & $730.35 \mathrm{H}$ & $92-10-15$ & $730.63 \mathrm{H}$ & & \\
\hline $88-10-15$ & $730.39 \mathrm{H}$ & $92-11-15$ & $730.61 \mathrm{H}$ & & \\
\hline $88-11-15$ & $730.41 \mathrm{H}$ & $92-12-15$ & $730.65 \mathrm{H}$ & & \\
\hline $88-12-15$ & $730.44 \mathrm{H}$ & $93-01-15$ & $730.64 \mathrm{H}$ & & \\
\hline 89-01-15 & $730.41 \mathrm{H}$ & $93-02-15$ & $730.66 \mathrm{H}$ & & \\
\hline $89-02-15$ & $730.45 \mathrm{H}$ & $93-03-15$ & $730.63 \mathrm{H}$ & & \\
\hline 89-03-15 & $730.51 \mathrm{H}$ & $93-04-15$ & $730.65 \mathrm{H}$ & & \\
\hline $89-04-15$ & $730.52 \mathrm{H}$ & $93-05-15$ & $730.64 \mathrm{H}$ & & \\
\hline $89-05-15$ & $730.54 \mathrm{H}$ & $93-06-15$ & $730.62 \mathrm{H}$ & & \\
\hline $89-06-15$ & $730.54 \mathrm{H}$ & $93-07-15$ & $730.60 \mathrm{H}$ & & \\
\hline $89-07-15$ & $730.51 \mathrm{H}$ & $93-08-15$ & $730.61 \mathrm{H}$ & & \\
\hline 89-08-15 & $730.53 \mathrm{H}$ & $93-09-15$ & $730.60 \mathrm{H}$ & & \\
\hline $89-09-15$ & $730.56 \mathrm{H}$ & $93-10-15$ & $730.64 \mathrm{H}$ & & \\
\hline
\end{tabular}

${ }^{1}$ Actual date of measurement applies to manual measurements only. For monthly mean water levels, the 15 th of each month was used. This was done to facilitate the plotting of the hydrographs for this report. 


\section{Well USW H-1, Tube 4}

[M, indicates manual water-level measurement; $\mathrm{H}$, indicates monthly mean water levels averaged from hourly transducer data]

\begin{tabular}{|c|c|c|c|c|c|}
\hline $\begin{array}{c}\text { Date }^{1} \\
\text { (year-month-day) }\end{array}$ & $\begin{array}{l}\text { Water-level } \\
\text { altitude } \\
\text { (meters) }\end{array}$ & $\begin{array}{c}\text { Date }^{1} \\
\text { (year-month-day) }\end{array}$ & $\begin{array}{c}\text { Water-level } \\
\text { altitude } \\
\text { (meters) }\end{array}$ & $\begin{array}{c}\text { Date }^{1} \\
\text { (year-month-day) }\end{array}$ & $\begin{array}{c}\text { Water-level } \\
\text { altitude } \\
\text { (moters) }\end{array}$ \\
\hline $85-02-15$ & $730.74 \mathrm{H}$ & $89-01-15$ & $730.92 \mathrm{H}$ & $92-08-15$ & $730.95 \mathrm{H}$ \\
\hline $85-03-15$ & $730.89 \mathrm{H}$ & $89-02-15$ & $730.88 \mathrm{H}$ & $92-09-15$ & $730.93 \mathrm{H}$ \\
\hline $85-04-15$ & $730.97 \mathrm{H}$ & $89-03-15$ & $730.90 \mathrm{H}$ & $92-10-15$ & $730.92 \mathrm{H}$ \\
\hline $85-05-15$ & $730.70 \mathrm{H}$ & $89-04-15$ & $730.90 \mathrm{H}$ & $92-11-15$ & $730.89 \mathrm{H}$ \\
\hline $85-06-15$ & $730.52 \mathrm{H}$ & $89-05-15$ & $730.90 \mathrm{H}$ & $92-12-15$ & $730.92 \mathrm{H}$ \\
\hline $85-07-15$ & $730.58 \mathrm{H}$ & $89-06-15$ & $730.91 \mathrm{H}$ & $93-01-15$ & $730.92 \mathrm{H}$ \\
\hline $85-09-15$ & $730.66 \mathrm{H}$ & $89-07-15$ & $730.92 \mathrm{H}$ & $93-02-15$ & $730.94 \mathrm{H}$ \\
\hline $85-11-15$ & $730.55 \mathrm{H}$ & $89-08-15$ & $730.98 \mathrm{H}$ & $93-03-15$ & $730.91 \mathrm{H}$ \\
\hline $85-12-15$ & $730.51 \mathrm{H}$ & $89-09-15$ & $730.99 \mathrm{H}$ & $93-04-15$ & $730.93 \mathrm{H}$ \\
\hline $86-01-15$ & $730.63 \mathrm{H}$ & $89-10-15$ & $730.96 \mathrm{H}$ & $93-05-15$ & $730.93 \mathrm{H}$ \\
\hline $86-02-15$ & $730.62 \mathrm{H}$ & $89-11-15$ & $730.93 \mathrm{H}$ & $93-06-15$ & $730.91 \mathrm{H}$ \\
\hline $86-03-15$ & $730.71 \mathrm{H}$ & $89-12-15$ & $730.90 \mathrm{H}$ & $93-07-15$ & $730.89 \mathrm{H}$ \\
\hline $86-04-15$ & $730.74 \mathrm{H}$ & $90-01-15$ & $730.92 \mathrm{H}$ & $93-08-15$ & $730.90 \mathrm{H}$ \\
\hline $86-05-15$ & $730.75 \mathrm{H}$ & $90-02-15$ & $730.91 \mathrm{H}$ & $93-09-15$ & $730.88 \mathrm{H}$ \\
\hline $86-06-15$ & $730.75 \mathrm{H}$ & $90-03-15$ & $730.93 \mathrm{H}$ & $93-10-15$ & $730.87 \mathrm{H}$ \\
\hline $86-07-15$ & $730.70 \mathrm{H}$ & $90-04-15$ & $730.94 \mathrm{H}$ & $93-11-15$ & $730.86 \mathrm{H}$ \\
\hline $86-08-15$ & $730.67 \mathrm{H}$ & $90-05-15$ & $730.94 \mathrm{H}$ & $93-12-15$ & $730.85 \mathrm{H}$ \\
\hline $86-09-15$ & $730.69 \mathrm{H}$ & $90-06-15$ & $730.91 \mathrm{H}$ & $94-01-15$ & $730.85 \mathrm{H}$ \\
\hline $86-10-15$ & $730.69 \mathrm{H}$ & $90-07-15$ & $730.90 \mathrm{H}$ & $94-02-15$ & $730.87 \mathrm{H}$ \\
\hline $86-11-15$ & $730.61 \mathrm{H}$ & $90-08-15$ & $730.91 \mathrm{H}$ & $94-03-15$ & $730.85 \mathrm{H}$ \\
\hline $86-12-15$ & $730.54 \mathrm{H}$ & $90-09-15$ & $730.92 \mathrm{H}$ & $94-04-15$ & $730.90 \mathrm{H}$ \\
\hline $87-01-15$ & $730.52 \mathrm{H}$ & $90-10-15$ & $730.92 \mathrm{H}$ & $94-05-15$ & $730.89 \mathrm{H}$ \\
\hline $87-02-15$ & $730.52 \mathrm{H}$ & $90-11-15$ & $730.91 \mathrm{H}$ & $94-06-15$ & $730.88 \mathrm{H}$ \\
\hline $87-03-15$ & $730.53 \mathrm{H}$ & $90-12-15$ & $730.91 \mathrm{H}$ & $94-07-15$ & $730.85 \mathrm{H}$ \\
\hline $87-04-15$ & $730.62 \mathrm{H}$ & $91-01-15$ & $730.94 \mathrm{H}$ & $94-08-15$ & $730.80 \mathrm{H}$ \\
\hline $87-05-15$ & $730.66 \mathrm{H}$ & $91-02-15$ & $730.94 \mathrm{H}$ & $94-09-15$ & $730.85 \mathrm{H}$ \\
\hline $87-06-15$ & $730.65 \mathrm{H}$ & $91-03-15$ & $730.96 \mathrm{H}$ & $94-10-15$ & $730.87 \mathrm{H}$ \\
\hline $87-07-15$ & $730.65 \mathrm{H}$ & $91-04-15$ & $730.93 \mathrm{H}$ & $94-11-15$ & $730.86 \mathrm{H}$ \\
\hline $87-08-15$ & $730.70 \mathrm{H}$ & $91-05-15$ & $730.95 \mathrm{H}$ & $94-12-15$ & $730.88 \mathrm{H}$ \\
\hline $87-09-15$ & $730.75 \mathrm{H}$ & $91-06-15$ & $730.92 \mathrm{H}$ & $95-01-15$ & $730.90 \mathrm{H}$ \\
\hline $87-10-15$ & $730.78 \mathrm{H}$ & $91-07-15$ & $730.89 \mathrm{H}$ & $95-02-15$ & $730.88 \mathrm{H}$ \\
\hline $87-11-15$ & $730.81 \mathrm{H}$ & $91-09-15$ & $730.97 \mathrm{H}$ & $95-03-15$ & $730.89 \mathrm{H}$ \\
\hline $87-12-15$ & $730.83 \mathrm{H}$ & $91-10-15$ & $730.99 \mathrm{H}$ & $95-04-15$ & $730.92 \mathrm{H}$ \\
\hline $88-01-15$ & $730.85 \mathrm{H}$ & $91-11-15$ & $730.95 \mathrm{H}$ & $95-05-15$ & $730.93 \mathrm{H}$ \\
\hline $88-02-15$ & $730.84 \mathrm{H}$ & $91-12-15$ & $730.91 \mathrm{H}$ & $95-06-15$ & $730.90 \mathrm{H}$ \\
\hline $88-03-15$ & $730.83 \mathrm{H}$ & $92-01-15$ & $730.86 \mathrm{H}$ & $95-07-15$ & $730.91 \mathrm{H}$ \\
\hline $88-04-15$ & $730.89 \mathrm{H}$ & $92-02-15$ & $730.94 \mathrm{H}$ & $95-08-15$ & $730.93 \mathrm{H}$ \\
\hline $88-05-15$ & $731.04 \mathrm{H}$ & $92-03-15$ & $730.94 \mathrm{H}$ & $95-09-15$ & $730.92 \mathrm{H}$ \\
\hline $88-08-15$ & $731.02 \mathrm{H}$ & $92-04-15$ & $730.91 \mathrm{H}$ & $95-10-25$ & $730.88 \mathrm{M}$ \\
\hline $88-09-15$ & $730.99 \mathrm{H}$ & $92-05-15$ & $730.92 \mathrm{H}$ & $95-12-05$ & $730.89 \mathrm{M}$ \\
\hline $88-10-15$ & $730.98 \mathrm{H}$ & $92-06-15$ & $730.96 \mathrm{H}$ & & \\
\hline $88-12-15$ & $731.04 \mathrm{H}$ & $92-07-15$ & $730.97 \mathrm{H}$ & & \\
\hline
\end{tabular}

${ }^{1}$ Actual date of measurement applies to manual measurements only. For monthly mean water levels, the 15 th of each month was used. This was done to facilitate the plotting of the hydrographs for this report. 


\section{Well USW H-3, Upper Zone}

[M, indicates manual water-level measurement; $\mathrm{H}$, indicates monthly mean water levels averaged from hourly transducer data]

\begin{tabular}{|c|c|c|c|c|c|}
\hline $\begin{array}{c}\text { Date }^{1} \\
\text { (year-month-day) }\end{array}$ & $\begin{array}{c}\text { Water-level } \\
\text { altltude } \\
\text { (meters) }\end{array}$ & $\begin{array}{c}\text { Date }^{1} \\
\text { (year-month-day) }\end{array}$ & $\begin{array}{c}\text { Water-level } \\
\text { altitude } \\
\text { (meters) }\end{array}$ & $\begin{array}{c}\text { Date }^{1} \\
\text { (year-month-day) }\end{array}$ & $\begin{array}{l}\text { Water-level } \\
\text { altitude } \\
\text { (meters) }\end{array}$ \\
\hline $85-01-04$ & $731.22 \mathrm{M}$ & $88-08-15$ & $731.41 \mathrm{H}$ & $92-04-15$ & $731.24 \mathrm{H}$ \\
\hline $85-01-19$ & $731.16 \mathrm{M}$ & $88-09-15$ & $731.39 \mathrm{H}$ & $92-05-15$ & $731.30 \mathrm{H}$ \\
\hline $85-02-05$ & $731.31 \mathrm{M}$ & $88-10-15$ & $731.42 \mathrm{H}$ & $92-06-15$ & $731.31 \mathrm{H}$ \\
\hline $85-03-05$ & $731.40 \mathrm{M}$ & $88-11-15$ & $731.54 \mathrm{H}$ & $92-07-15$ & $731.23 \mathrm{H}$ \\
\hline $85-03-29$ & $731.22 \mathrm{M}$ & $88-12-15$ & $731.66 \mathrm{H}$ & $92-08-15$ & $731.20 \mathrm{H}$ \\
\hline $85-04-12$ & $731.22 \mathrm{M}$ & $89-02-15$ & $731.89 \mathrm{H}$ & $92-09-15$ & $731.19 \mathrm{H}$ \\
\hline $85-04-25$ & $731.32 \mathrm{M}$ & $89-03-15$ & $731.87 \mathrm{H}$ & $92-10-15$ & $731.18 \mathrm{H}$ \\
\hline $85-06-13$ & $731.72 \mathrm{M}$ & $89-04-15$ & $731.89 \mathrm{H}$ & $92-11-15$ & $731.15 \mathrm{H}$ \\
\hline $85-06-18$ & $731.69 \mathrm{M}$ & $89-05-15$ & $731.90 \mathrm{H}$ & $92-12-15$ & $731.21 \mathrm{H}$ \\
\hline $85-07-09$ & $731.70 \mathrm{M}$ & $89-06-15$ & $731.90 \mathrm{H}$ & $93-01-15$ & $731.20 \mathrm{H}$ \\
\hline $85-08-05$ & $731.71 \mathrm{M}$ & $89-07-15$ & $731.87 \mathrm{H}$ & $93-02-15$ & $731.22 \mathrm{H}$ \\
\hline $85-10-15$ & $731.72 \mathrm{M}$ & $89-08-15$ & $731.91 \mathrm{H}$ & $93-03-15$ & $731.18 \mathrm{H}$ \\
\hline $85-11-15$ & $731.89 \mathrm{H}$ & $89-09-15$ & $731.90 \mathrm{H}$ & $93-04-15$ & $731.20 \mathrm{H}$ \\
\hline $85-12-15$ & $731.91 \mathrm{H}$ & $89-10-15$ & $731.90 \mathrm{H}$ & $93-05-15$ & $731.20 \mathrm{H}$ \\
\hline $86-01-15$ & $731.80 \mathrm{H}$ & $89-11-15$ & $731.93 \mathrm{H}$ & $93-06-15$ & $731.19 \mathrm{H}$ \\
\hline $86-02-15$ & $731.85 \mathrm{H}$ & $89-12-15$ & $731.93 \mathrm{H}$ & $93-07-15$ & $731.21 \mathrm{H}$ \\
\hline $86-03-15$ & $731.86 \mathrm{H}$ & $90-01-15$ & $731.90 \mathrm{H}$ & $93-08-15$ & $731.21 \mathrm{H}$ \\
\hline $86-04-15$ & $731.87 \mathrm{H}$ & $90-02-15$ & $731.82 \mathrm{H}$ & $93-09-15$ & $731.21 \mathrm{H}$ \\
\hline $86-05-15$ & $731.87 \mathrm{H}$ & $90-03-15$ & $731.84 \mathrm{H}$ & $93-10-15$ & $731.23 \mathrm{H}$ \\
\hline $86-06-15$ & $731.86 \mathrm{H}$ & $90-04-15$ & $731.90 \mathrm{H}$ & $93-11-15$ & $731.24 \mathrm{H}$ \\
\hline $86-07-15$ & $731.84 \mathrm{H}$ & $90-05-15$ & $731.91 \mathrm{H}$ & $93-12-15$ & $731.24 \mathrm{H}$ \\
\hline $86-08-15$ & $731.83 \mathrm{H}$ & $90-06-15$ & $731.82 \mathrm{H}$ & $94-01-15$ & $731.23 \mathrm{H}$ \\
\hline $86-09-15$ & $731.86 \mathrm{H}$ & $90-07-15$ & $731.74 \mathrm{H}$ & $94-02-15$ & $731.23 \mathrm{H}$ \\
\hline $86-10-15$ & $731.83 \mathrm{H}$ & $90-08-15$ & $731.74 \mathrm{H}$ & $94-03-15$ & $731.22 \mathrm{H}$ \\
\hline $86-11-15$ & $731.84 \mathrm{H}$ & $90-09-15$ & $731.74 \mathrm{H}$ & $94-04-15$ & $731.24 \mathrm{H}$ \\
\hline $86-12-15$ & $731.85 \mathrm{H}$ & $90-10-15$ & $731.73 \mathrm{H}$ & $94-05-15$ & $731.25 \mathrm{H}$ \\
\hline $87-01-15$ & $731.88 \mathrm{H}$ & $90-11-15$ & $731.74 \mathrm{H}$ & $94-06-15$ & $731.26 \mathrm{H}$ \\
\hline $87-02-15$ & $731.90 \mathrm{H}$ & $90-12-15$ & $731.72 \mathrm{H}$ & $94-07-15$ & $731.29 \mathrm{H}$ \\
\hline $87-03-15$ & $731.89 \mathrm{H}$ & 91-02-01 & $731.33 \mathrm{M}$ & $94-08-15$ & $731.26 \mathrm{H}$ \\
\hline $87-04-15$ & $731.86 \mathrm{H}$ & $91-02-27$ & $731.46 \mathrm{M}$ & $94-09-15$ & $731.21 \mathrm{H}$ \\
\hline $87-05-15$ & $731.84 \mathrm{H}$ & 91-03-29 & $731.32 \mathrm{M}$ & $94-10-15$ & $731.23 \mathrm{H}$ \\
\hline $87-06-15$ & $731.81 \mathrm{H}$ & $91-04-22$ & $731.36 \mathrm{M}$ & $94-11-15$ & $731.24 \mathrm{H}$ \\
\hline $87-07-15$ & $731.82 \mathrm{H}$ & $91-05-14$ & $731.37 \mathrm{M}$ & $94-12-15$ & $731.25 \mathrm{H}$ \\
\hline $87-08-15$ & $731.79 \mathrm{H}$ & $91-06-19$ & $731.38 \mathrm{M}$ & $95-01-15$ & $731.26 \mathrm{H}$ \\
\hline $87-09-15$ & $731.78 \mathrm{H}$ & $91-07-02$ & $731.32 \mathrm{M}$ & $95-02-15$ & $731.26 \mathrm{H}$ \\
\hline $87-10-15$ & $731.75 \mathrm{H}$ & $91-08-15$ & $731.25 \mathrm{H}$ & $95-03-15$ & $731.29 \mathrm{H}$ \\
\hline $87-11-15$ & $731.77 \mathrm{H}$ & $91-09-15$ & $731.11 \mathrm{H}$ & $95-04-15$ & $731.30 \mathrm{H}$ \\
\hline $87-12-15$ & $731.78 \mathrm{H}$ & $91-10-15$ & $731.07 \mathrm{H}$ & $95-05-15$ & $731.31 \mathrm{H}$ \\
\hline $88-01-15$ & $731.73 \mathrm{H}$ & $91-11-15$ & $731.20 \mathrm{H}$ & $95-06-15$ & $731.28 \mathrm{H}$ \\
\hline $88-04-15$ & $731.76 \mathrm{H}$ & $91-12-15$ & $731.35 \mathrm{H}$ & $95-07-15$ & $731.31 \mathrm{H}$ \\
\hline $88-05-15$ & $731.70 \mathrm{H}$ & $92-01-15$ & $731.27 \mathrm{H}$ & $95-08-15$ & $731.33 \mathrm{H}$ \\
\hline $88-06-15$ & $731.56 \mathrm{H}$ & $92-02-15$ & $731.26 \mathrm{H}$ & $95-09-15$ & $731.31 \mathrm{H}$ \\
\hline $88-07-15$ & $731.51 \mathrm{H}$ & $92-03-15$ & $731.25 \mathrm{H}$ & & \\
\hline
\end{tabular}

${ }^{1}$ Actual date of measurement applies to manual measurements only. For monthly mean water levels, the 15 th of each month was used. This was done to facilitate the plotting of the hydrographs for this report. 


\section{Well USW H-3, Lower Zone}

$[M$, indicates manual water-level measurement; $\mathrm{H}$, indicates monthly mean water levels averaged from hourly transducer data]

\begin{tabular}{|c|c|c|c|}
\hline $\begin{array}{c}\text { Date }^{1} \\
\text { (year-month-day) }\end{array}$ & $\begin{array}{c}\text { Water-level } \\
\text { altitude } \\
\text { (meters) }\end{array}$ & $\begin{array}{c}\text { Date }^{1} \\
\text { (year-month-day) }\end{array}$ & $\begin{array}{l}\text { Water-level } \\
\text { altitude } \\
\text { (meters) }\end{array}$ \\
\hline $91-02-01$ & $747.39 \mathrm{M}$ & $94-07-15$ & $758.26 \mathrm{H}$ \\
\hline $91-02-27$ & $748.58 \mathrm{M}$ & $94-08-15$ & $758.35 \mathrm{H}$ \\
\hline $91-03-29$ & $749.49 \mathrm{M}$ & $94-09-15$ & $758.45 \mathrm{H}$ \\
\hline $91-04-22$ & $750.05 \mathrm{M}$ & $94-10-15$ & $758.53 \mathrm{H}$ \\
\hline $91-05-14$ & $750.59 \mathrm{M}$ & $94-11-15$ & $758.62 \mathrm{H}$ \\
\hline 91-06-19 & $751.24 \mathrm{M}$ & $94-12-15$ & $758.74 \mathrm{H}$ \\
\hline $91-07-15$ & $751.52 \mathrm{H}$ & $95-01-15$ & $758.92 \mathrm{H}$ \\
\hline $91-08-15$ & $751.83 \mathrm{H}$ & $95-02-15$ & $758.99 \mathrm{H}$ \\
\hline $91-09-15$ & $752.11 \mathrm{H}$ & $95-03-15$ & $759.07 \mathrm{H}$ \\
\hline $91-10-15$ & $752.39 \mathrm{H}$ & $95-04-15$ & $759.15 \mathrm{H}$ \\
\hline $91-11-15$ & $752.69 \mathrm{H}$ & $95-05-15$ & $759.17 \mathrm{H}$ \\
\hline $91-12-15$ & $753.03 \mathrm{H}$ & $95-06-15$ & $759.22 \mathrm{H}$ \\
\hline $92-01-15$ & $753.37 \mathrm{H}$ & $95-07-15$ & $759.25 \mathrm{H}$ \\
\hline $92-02-15$ & $753.68 \mathrm{H}$ & $95-08-15$ & $759.29 \mathrm{H}$ \\
\hline $92-03-15$ & $753.90 \mathrm{H}$ & $95-09-15$ & $759.38 \mathrm{H}$ \\
\hline $92-04-15$ & $754.05 \mathrm{H}$ & $95-10-25$ & $759.47 \mathrm{M}$ \\
\hline $92-05-15$ & $754.32 \mathrm{H}$ & $95-12-12$ & $759.61 \mathrm{M}$ \\
\hline $92-06-15$ & $754.54 \mathrm{H}$ & & \\
\hline $92-07-15$ & $754.90 \mathrm{H}$ & & \\
\hline $92-08-15$ & $755.10 \mathrm{H}$ & & \\
\hline $92-09-15$ & $755.34 \mathrm{H}$ & & \\
\hline $92-10-15$ & $755.50 \mathrm{H}$ & & \\
\hline $92-11-15$ & $755.69 \mathrm{H}$ & & \\
\hline $92-12-15$ & $755.91 \mathrm{H}$ & & \\
\hline $93-01-15$ & $756.07 \mathrm{H}$ & & \\
\hline $93-02-15$ & $756.26 \mathrm{H}$ & & \\
\hline $93-03-15$ & $756.35 \mathrm{H}$ & & \\
\hline $93-04-15$ & $756.54 \mathrm{H}$ & & \\
\hline $93-05-15$ & $756.66 \mathrm{H}$ & & \\
\hline $93-06-15$ & $756.80 \mathrm{H}$ & & \\
\hline $93-07-15$ & $756.92 \mathrm{H}$ & & \\
\hline $93-08-15$ & $757.06 \mathrm{H}$ & & \\
\hline 93-09-15 & $757.16 \mathrm{H}$ & & \\
\hline $93-10-15$ & $757.27 \mathrm{H}$ & & \\
\hline $93-11-15$ & $757.40 \mathrm{H}$ & & \\
\hline $93-12-15$ & $757.50 \mathrm{H}$ & & \\
\hline $94-01-15$ & $757.54 \mathrm{H}$ & & \\
\hline $94-02-15$ & $757.70 \mathrm{H}$ & & \\
\hline $94-03-15$ & $757.77 \mathrm{H}$ & & \\
\hline $94-04-15$ & $757.93 \mathrm{H}$ & & \\
\hline $94-05-15$ & $758.08 \mathrm{H}$ & & \\
\hline $94-06-15$ & $758.17 \mathrm{H}$ & & \\
\hline
\end{tabular}

${ }^{1}$ Actual date of measurement applies to manual measurements only. For monthly mean water levels, the 15th of each month was used. This was done to facilitate the plotting of the hydrographs for this report. 


\section{Well USW H-4, Upper Zone}

[M, indicates manual water-level measurement; $\mathrm{H}$, indicates monthly mean water levels averaged from hourly transducer data]

\begin{tabular}{|c|c|c|c|c|c|}
\hline $\begin{array}{c}\text { Date }^{1} \\
\text { (year-month-day) }\end{array}$ & $\begin{array}{l}\text { Water-level } \\
\text { altitude } \\
\text { (meters) }\end{array}$ & $\begin{array}{c}\text { Date }^{1} \\
\text { (year-month-day) }\end{array}$ & $\begin{array}{l}\text { Water-level } \\
\text { altitude } \\
\text { (meters) }\end{array}$ & $\begin{array}{c}\text { Date }^{1} \\
\text { (year-month-day) }\end{array}$ & $\begin{array}{l}\text { Water-level } \\
\text { altitude } \\
\text { (meters) }\end{array}$ \\
\hline $85-02-14$ & $730.20 \mathrm{M}$ & $88-10-15$ & $730.34 \mathrm{H}$ & $92-05-15$ & $730.47 \mathrm{H}$ \\
\hline $85-03-15$ & $730.33 \mathrm{H}$ & $88-11-15$ & $730.36 \mathrm{H}$ & $92-06-15$ & $730.49 \mathrm{H}$ \\
\hline $85-04-15$ & $730.21 \mathrm{H}$ & $88-12-15$ & $730.39 \mathrm{H}$ & $92-07-15$ & $730.46 \mathrm{H}$ \\
\hline $85-05-15$ & $730.23 \mathrm{H}$ & $89-01-15$ & $730.39 \mathrm{H}$ & $92-08-15$ & $730.44 \mathrm{H}$ \\
\hline $85-06-15$ & $730.31 \mathrm{H}$ & $89-02-15$ & $730.42 \mathrm{H}$ & $92-09-15$ & $730.42 \mathrm{H}$ \\
\hline $85-07-15$ & $730.31 \mathrm{H}$ & $89-03-15$ & $730.39 \mathrm{H}$ & $92-10-15$ & $730.41 \mathrm{H}$ \\
\hline $85-08-15$ & $730.26 \mathrm{H}$ & $89-04-15$ & $730.39 \mathrm{H}$ & $92-11-15$ & $730.38 \mathrm{H}$ \\
\hline $85-09-15$ & $730.28 \mathrm{H}$ & 89-05-15 & $730.38 \mathrm{H}$ & $92-12-15$ & $730.41 \mathrm{H}$ \\
\hline $85-10-15$ & $730.35 \mathrm{H}$ & $89-06-15$ & $730.39 \mathrm{H}$ & $93-01-15$ & $730.40 \mathrm{H}$ \\
\hline $85-11-15$ & $730.34 \mathrm{H}$ & $89-07-15$ & $730.38 \mathrm{H}$ & $93-02-15$ & $730.44 \mathrm{H}$ \\
\hline $85-12-15$ & $730.34 \mathrm{H}$ & $89-08-15$ & $730.41 \mathrm{H}$ & $93-03-15$ & $730.41 \mathrm{H}$ \\
\hline $86-01-15$ & $730.38 \mathrm{H}$ & $89-09-15$ & $730.39 \mathrm{H}$ & $93-04-15$ & $730.43 \mathrm{H}$ \\
\hline $86-02-15$ & $730.41 \mathrm{H}$ & $89-10-15$ & $730.37 \mathrm{H}$ & $93-05-15$ & $730.42 \mathrm{H}$ \\
\hline $86-03-15$ & $730.33 \mathrm{H}$ & $89-11-15$ & $730.35 \mathrm{H}$ & $93-06-15$ & $730.40 \mathrm{H}$ \\
\hline $86-04-15$ & $730.37 \mathrm{H}$ & $89-12-15$ & $730.36 \mathrm{H}$ & $93-07-15$ & $730.40 \mathrm{H}$ \\
\hline $86-05-15$ & $730.32 \mathrm{H}$ & $90-01-15$ & $730.39 \mathrm{H}$ & $93-08-15$ & $730.41 \mathrm{H}$ \\
\hline $86-06-15$ & $730.31 \mathrm{H}$ & $90-02-15$ & $730.40 \mathrm{H}$ & 93-09-15 & $730.40 \mathrm{H}$ \\
\hline $86-07-15$ & $730.31 \mathrm{H}$ & $90-03-15$ & $730.41 \mathrm{H}$ & $93-10-15$ & $730.42 \mathrm{H}$ \\
\hline $86-08-15$ & $730.32 \mathrm{H}$ & $90-04-15$ & $730.41 \mathrm{H}$ & $93-11-15$ & $730.42 \mathrm{H}$ \\
\hline $86-09-15$ & $730.35 \mathrm{H}$ & $90-05-15$ & $730.40 \mathrm{H}$ & $93-12-15$ & $730.41 \mathrm{H}$ \\
\hline $86-10-15$ & $730.33 \mathrm{H}$ & $90-06-15$ & $730.37 \mathrm{H}$ & $94-01-15$ & $730.42 \mathrm{H}$ \\
\hline $86-11-15$ & $730.35 \mathrm{H}$ & $90-07-15$ & $730.36 \mathrm{H}$ & $94-02-15$ & $730.43 \mathrm{H}$ \\
\hline $86-12-15$ & $730.36 \mathrm{H}$ & $90-08-15$ & $730.37 \mathrm{H}$ & $94-03-15$ & $730.38 \mathrm{H}$ \\
\hline $87-01-15$ & $730.40 \mathrm{H}$ & $90-09-15$ & $730.41 \mathrm{H}$ & $94-04-15$ & $730.38 \mathrm{H}$ \\
\hline $87-02-15$ & $730.43 \mathrm{H}$ & $90-10-15$ & $730.43 \mathrm{H}$ & $94-05-15$ & $730.38 \mathrm{H}$ \\
\hline $87-03-15$ & $730.44 \mathrm{H}$ & $90-11-15$ & $730.47 \mathrm{H}$ & $94-06-15$ & $730.37 \mathrm{H}$ \\
\hline $87-04-15$ & $730.45 \mathrm{H}$ & $90-12-15$ & $730.49 \mathrm{H}$ & $94-07-15$ & $730.39 \mathrm{H}$ \\
\hline $87-05-15$ & $730.44 \mathrm{H}$ & $91-01-15$ & $730.49 \mathrm{H}$ & $94-08-15$ & $730.40 \mathrm{H}$ \\
\hline $87-06-15$ & $730.43 \mathrm{H}$ & $91-02-15$ & $730.51 \mathrm{H}$ & $94-09-15$ & $730.39 \mathrm{H}$ \\
\hline $87-07-15$ & $730.45 \mathrm{H}$ & $91-03-15$ & $730.52 \mathrm{H}$ & $94-10-15$ & $730.40 \mathrm{H}$ \\
\hline $87-08-15$ & $730.43 \mathrm{H}$ & $91-04-15$ & $730.51 \mathrm{H}$ & $94-11-15$ & $730.40 \mathrm{H}$ \\
\hline $87-09-15$ & $730.44 \mathrm{H}$ & $91-05-15$ & $730.52 \mathrm{H}$ & $94-12-15$ & $730.40 \mathrm{H}$ \\
\hline $87-10-15$ & $730.44 \mathrm{H}$ & $91-06-15$ & $730.50 \mathrm{H}$ & $95-01-15$ & $730.39 \mathrm{H}$ \\
\hline $87-11-15$ & $730.43 \mathrm{H}$ & $91-07-15$ & $730.48 \mathrm{H}$ & $95-02-15$ & $730.37 \mathrm{H}$ \\
\hline $87-12-15$ & $730.35 \mathrm{H}$ & $91-08-15$ & $730.49 \mathrm{H}$ & $95-03-15$ & $730.37 \mathrm{H}$ \\
\hline $88-01-15$ & $730.33 \mathrm{H}$ & $91-09-15$ & $730.49 \mathrm{H}$ & $95-04-15$ & $730.37 \mathrm{H}$ \\
\hline $88-02-15$ & $730.33 \mathrm{H}$ & $91-10-15$ & $730.48 \mathrm{H}$ & $95-05-15$ & $730.34 \mathrm{H}$ \\
\hline 88-03-15 & $730.32 \mathrm{H}$ & $91-11-15$ & $730.47 \mathrm{H}$ & $95-06-15$ & $730.35 \mathrm{H}$ \\
\hline $88-04-15$ & $730.32 \mathrm{H}$ & $91-12-15$ & $730.48 \mathrm{H}$ & $95-07-15$ & $730.40 \mathrm{H}$ \\
\hline $88-06-15$ & $730.37 \mathrm{H}$ & $92-01-15$ & $730.46 \mathrm{H}$ & $95-08-15$ & $730.40 \mathrm{H}$ \\
\hline $88-07-15$ & $730.34 \mathrm{H}$ & $92-02-15$ & $730.49 \mathrm{H}$ & $95-09-15$ & $730.37 \mathrm{H}$ \\
\hline 88-08-15 & $730.35 \mathrm{H}$ & $92-03-15$ & $730.51 \mathrm{H}$ & $95-12-12$ & $730.41 \mathrm{M}$ \\
\hline $88-09-15$ & $730.34 \mathrm{H}$ & $92-04-15$ & $730.47 \mathrm{H}$ & & \\
\hline
\end{tabular}

${ }^{1}$ Actual date of measurement applies to manual measurements only. For monthly mean water levels, the 15 th of each month was used. This was done to facilitate the plotting of the hydrographs for this report. 


\section{Well USW H-4, Lower Zone}

$[\mathrm{M}$, indicates manual water-level measurement; $\mathrm{H}$, indicates monthly mean water levels averaged from hourly transducer data]

\begin{tabular}{|c|c|c|c|c|c|}
\hline $\begin{array}{c}\text { Date }^{1} \\
\text { (year-month-day) }\end{array}$ & $\begin{array}{l}\text { Water-level } \\
\text { altitude } \\
\text { (meters) }\end{array}$ & $\begin{array}{c}\text { Date }^{1} \\
\text { (year-month-day) }\end{array}$ & $\begin{array}{l}\text { Water-level } \\
\text { altitude } \\
\text { (meters) }\end{array}$ & $\begin{array}{c}\text { Date }^{1} \\
\text { (year-month-day) }\end{array}$ & $\begin{array}{l}\text { Water-level } \\
\text { altitude } \\
\text { (meters) }\end{array}$ \\
\hline $85-02-15$ & $730.31 \mathrm{H}$ & $90-10-15$ & $730.55 \mathrm{H}$ & $94-06-15$ & $730.48 \mathrm{H}$ \\
\hline $85-03-15$ & $730.33 \mathrm{H}$ & $90-11-15$ & $730.51 \mathrm{H}$ & $94-07-15$ & $730.47 \mathrm{H}$ \\
\hline $85-04-15$ & $730.34 \mathrm{H}$ & $90-12-15$ & $730.52 \mathrm{H}$ & $94-08-15$ & $730.46 \mathrm{H}$ \\
\hline $85-05-15$ & $730.33 \mathrm{H}$ & $91-01-15$ & $730.51 \mathrm{H}$ & $94-09-15$ & $730.46 \mathrm{H}$ \\
\hline $85-09-15$ & $730.46 \mathrm{H}$ & $91-02-15$ & $730.52 \mathrm{H}$ & $94-10-15$ & $730.47 \mathrm{H}$ \\
\hline $86-06-15$ & $730.44 \mathrm{H}$ & $91-03-15$ & $730.56 \mathrm{H}$ & $94-11-15$ & $730.47 \mathrm{H}$ \\
\hline $86-07-15$ & $730.45 \mathrm{H}$ & $91-04-15$ & $730.55 \mathrm{H}$ & $94-12-15$ & $730.48 \mathrm{H}$ \\
\hline $86-08-15$ & $730.45 \mathrm{H}$ & $91-05-15$ & $730.58 \mathrm{H}$ & $95-01-15$ & $730.51 \mathrm{H}$ \\
\hline $86-09-15$ & $730.48 \mathrm{H}$ & $91-06-15$ & $730.55 \mathrm{H}$ & $95-02-15$ & $730.51 \mathrm{H}$ \\
\hline $86-10-15$ & $730.44 \mathrm{H}$ & $91-07-15$ & $730.46 \mathrm{H}$ & $95-03-15$ & $730.53 \mathrm{H}$ \\
\hline $86-11-15$ & $730.43 \mathrm{H}$ & $91-08-15$ & $730.51 \mathrm{H}$ & $95-04-15$ & $730.54 \mathrm{H}$ \\
\hline $87-11-15$ & $730.51 \mathrm{H}$ & $91-09-15$ & $730.56 \mathrm{H}$ & $95-05-15$ & $730.53 \mathrm{H}$ \\
\hline $87-12-15$ & $730.54 \mathrm{H}$ & $91-10-15$ & $730.59 \mathrm{H}$ & $95-06-15$ & $730.47 \mathrm{H}$ \\
\hline $88-01-15$ & $730.28 \mathrm{H}$ & $91-11-15$ & $730.71 \mathrm{H}$ & $95-07-15$ & $730.47 \mathrm{H}$ \\
\hline $88-02-15$ & $730.21 \mathrm{H}$ & $91-12-15$ & $730.83 \mathrm{H}$ & $95-08-15$ & $730.48 \mathrm{H}$ \\
\hline $88-03-15$ & $730.18 \mathrm{H}$ & $92-01-15$ & $730.60 \mathrm{H}$ & $95-09-15$ & $730.46 \mathrm{H}$ \\
\hline $88-04-15$ & $730.20 \mathrm{H}$ & $92-02-15$ & $730.59 \mathrm{H}$ & $95-12-12$ & $730.52 \mathrm{M}$ \\
\hline $88-05-15$ & $730.21 \mathrm{H}$ & $92-03-15$ & $730.62 \mathrm{H}$ & & \\
\hline 88-06-15 & $730.31 \mathrm{H}$ & $92-04-15$ & $730.57 \mathrm{H}$ & & \\
\hline $88-07-15$ & $730.36 \mathrm{H}$ & $92-05-15$ & $730.59 \mathrm{H}$ & & \\
\hline $88-08-15$ & $730.43 \mathrm{H}$ & $92-06-15$ & $730.69 \mathrm{H}$ & & \\
\hline $88-09-15$ & $730.49 \mathrm{H}$ & $92-07-15$ & $730.65 \mathrm{H}$ & & \\
\hline $88-10-15$ & $730.53 \mathrm{H}$ & $92-08-15$ & $730.58 \mathrm{H}$ & & \\
\hline $88-12-15$ & $730.59 \mathrm{H}$ & $92-09-15$ & $730.56 \mathrm{H}$ & & \\
\hline $88-11-15$ & $730.56 \mathrm{H}$ & $92-10-15$ & $730.53 \mathrm{H}$ & & \\
\hline $89-04-15$ & $730.60 \mathrm{H}$ & $92-11-15$ & $730.49 \mathrm{H}$ & & \\
\hline $89-05-15$ & $730.59 \mathrm{H}$ & $92-12-15$ & $730.51 \mathrm{H}$ & & \\
\hline $89-06-15$ & $730.60 \mathrm{H}$ & $93-01-15$ & $730.52 \mathrm{H}$ & & \\
\hline $89-07-15$ & $730.60 \mathrm{H}$ & 93-02-15 & $730.57 \mathrm{H}$ & & \\
\hline $89-08-15$ & $730.64 \mathrm{H}$ & $93-03-15$ & $730.55 \mathrm{H}$ & & \\
\hline $89-09-15$ & $730.62 \mathrm{H}$ & $93-04-15$ & $730.59 \mathrm{H}$ & & \\
\hline $89-10-15$ & $730.62 \mathrm{H}$ & $93-05-15$ & $730.53 \mathrm{H}$ & & \\
\hline $89-11-15$ & $730.60 \mathrm{H}$ & $93-06-15$ & $730.55 \mathrm{H}$ & & \\
\hline $89-12-15$ & $730.59 \mathrm{H}$ & $93-09-15$ & $730.48 \mathrm{H}$ & & \\
\hline $90-01-15$ & $730.61 \mathrm{H}$ & $93-10-15$ & $730.48 \mathrm{H}$ & & \\
\hline $90-02-15$ & $730.60 \mathrm{H}$ & $93-11-15$ & $730.49 \mathrm{H}$ & & \\
\hline $90-03-15$ & $730.63 \mathrm{H}$ & $93-12-15$ & $730.49 \mathrm{H}$ & & \\
\hline $90-04-15$ & $730.62 \mathrm{H}$ & $94-01-15$ & $730.51 \mathrm{H}$ & & \\
\hline $90-05-15$ & $730.65 \mathrm{H}$ & $94-02-15$ & $730.52 \mathrm{H}$ & & \\
\hline $90-06-15$ & $730.64 \mathrm{H}$ & $94-03-15$ & $730.51 \mathrm{H}$ & & \\
\hline $90-07-15$ & $730.63 \mathrm{H}$ & $94-04-15$ & $730.52 \mathrm{H}$ & & \\
\hline $90-08-15$ & $730.62 \mathrm{H}$ & $94-05-15$ & $730.49 \mathrm{H}$ & & \\
\hline
\end{tabular}

${ }^{1}$ Actual date of measurement applies to manual measurements only. For monthly mean water levels, the 15 th of each month was used. This was done to facilitate the plotting of the hydrographs for this report. 


\section{Well USW H-5, Upper Zone}

[M, indicates manual water-level measurement; $\mathrm{H}$, indicates monthly mean water levels averaged from hourly transducer data]

\begin{tabular}{|c|c|c|c|c|c|}
\hline $\begin{array}{c}\text { Date }^{1} \\
\text { (year-month-day) }\end{array}$ & $\begin{array}{c}\text { Water-level } \\
\text { altitude } \\
\text { (meters) }\end{array}$ & $\begin{array}{c}\text { Date }^{1} \\
\text { (year-month-day) }\end{array}$ & $\begin{array}{c}\text { Water-level } \\
\text { altitude } \\
\text { (meters) }\end{array}$ & $\begin{array}{c}\text { Date }^{1} \\
\text { (year-month-day) }\end{array}$ & $\begin{array}{l}\text { Water-level } \\
\text { altitude } \\
\text { (meters) }\end{array}$ \\
\hline $85-01-04$ & $774.96 \mathrm{M}$ & $90-07-15$ & $775.44 \mathrm{H}$ & $94-01-15$ & $775.47 \mathrm{H}$ \\
\hline $85-01-19$ & $775.04 \mathrm{M}$ & $90-08-15$ & $775.41 \mathrm{H}$ & $94-02-15$ & $775.50 \mathrm{H}$ \\
\hline $85-02-22$ & $775.03 \mathrm{M}$ & $90-09-15$ & $775.40 \mathrm{H}$ & $94-03-15$ & $775.50 \mathrm{H}$ \\
\hline $85-03-15$ & $775.13 \mathrm{H}$ & $90-10-15$ & $775.39 \mathrm{H}$ & $94-04-15$ & $775.51 \mathrm{H}$ \\
\hline $85-04-15$ & $775.10 \mathrm{H}$ & $90-11-15$ & $775.39 \mathrm{H}$ & $94-05-15$ & $775.50 \mathrm{H}$ \\
\hline $85-05-15$ & $775.12 \mathrm{H}$ & $90-12-15$ & $775.41 \mathrm{H}$ & $94-06-15$ & $775.47 \mathrm{H}$ \\
\hline $85-06-15$ & $775.15 \mathrm{H}$ & $91-01-15$ & $775.38 \mathrm{H}$ & $94-07-15$ & $775.46 \mathrm{H}$ \\
\hline $85-07-15$ & $775.23 \mathrm{H}$ & $91-02-15$ & $775.40 \mathrm{H}$ & $94-08-15$ & $775.46 \mathrm{H}$ \\
\hline $85-08-15$ & $775.36 \mathrm{H}$ & $91-03-15$ & $775.46 \mathrm{H}$ & $94-09-15$ & $775.48 \mathrm{H}$ \\
\hline $85-09-15$ & $775.50 \mathrm{H}$ & $91-04-15$ & $775.45 \mathrm{H}$ & $94-10-15$ & $775.50 \mathrm{H}$ \\
\hline $86-02-15$ & $775.57 \mathrm{H}$ & $91-05-15$ & $775.46 \mathrm{H}$ & $94-11-15$ & $775.47 \mathrm{H}$ \\
\hline $86-03-15$ & $775.62 \mathrm{H}$ & $91-06-15$ & $775.44 \mathrm{H}$ & $94-12-15$ & $775.46 \mathrm{H}$ \\
\hline $86-04-15$ & $775.47 \mathrm{H}$ & $91-07-15$ & $775.40 \mathrm{H}$ & $95-01-15$ & $775.46 \mathrm{H}$ \\
\hline $86-05-15$ & $775.36 \mathrm{H}$ & $91-08-15$ & $775.39 \mathrm{H}$ & $95-02-15$ & $775.42 \mathrm{H}$ \\
\hline $86-06-15$ & $775.42 \mathrm{H}$ & $91-09-15$ & $775.40 \mathrm{H}$ & $95-03-15$ & $775.44 \mathrm{H}$ \\
\hline $86-07-15$ & $775.36 \mathrm{H}$ & $91-10-15$ & $775.42 \mathrm{H}$ & $95-04-15$ & $775.44 \mathrm{H}$ \\
\hline $86-08-15$ & $775.32 \mathrm{H}$ & $91-11-15$ & $775.43 \mathrm{H}$ & $95-05-15$ & $775.42 \mathrm{H}$ \\
\hline $86-09-15$ & $775.38 \mathrm{H}$ & $91-12-15$ & $775.54 \mathrm{H}$ & $95-06-15$ & $775.38 \mathrm{H}$ \\
\hline $86-10-15$ & $775.43 \mathrm{H}$ & $92-01-15$ & $775.63 \mathrm{H}$ & $95-07-15$ & $775.35 \mathrm{H}$ \\
\hline $86-11-15$ & $775.41 \mathrm{H}$ & $92-02-15$ & $775.67 \mathrm{H}$ & $95-08-15$ & $775.38 \mathrm{H}$ \\
\hline $87-10-15$ & $775.47 \mathrm{H}$ & $92-03-15$ & $775.70 \mathrm{H}$ & $95-09-15$ & $775.37 \mathrm{H}$ \\
\hline $87-11-15$ & $775.55 \mathrm{H}$ & $92-04-15$ & $775.66 \mathrm{H}$ & $95-10-15$ & $775.36 \mathrm{H}$ \\
\hline $88-03-15$ & $775.53 \mathrm{H}$ & $92-05-15$ & $775.62 \mathrm{H}$ & $95-12-18$ & $775.40 \mathrm{M}$ \\
\hline $88-04-15$ & $775.52 \mathrm{H}$ & $92-06-15$ & $775.64 \mathrm{H}$ & & \\
\hline $88-05-15$ & $775.49 \mathrm{H}$ & $92-07-15$ & $775.64 \mathrm{H}$ & & \\
\hline $88-06-15$ & $775.46 \mathrm{H}$ & $92-08-15$ & $775.61 \mathrm{H}$ & & \\
\hline $88-07-15$ & $775.44 \mathrm{H}$ & $92-09-15$ & $775.63 \mathrm{H}$ & & \\
\hline $88-08-15$ & $775.47 \mathrm{H}$ & $92-10-15$ & $775.65 \mathrm{H}$ & & \\
\hline $88-09-15$ & $775.46 \mathrm{H}$ & $92-11-15$ & $775.65 \mathrm{H}$ & & \\
\hline $88-10-15$ & $775.46 \mathrm{H}$ & $92-12-15$ & $775.70 \mathrm{H}$ & & \\
\hline $88-11-15$ & $775.47 \mathrm{H}$ & $93-01-15$ & $775.72 \mathrm{H}$ & & \\
\hline $88-12-15$ & $775.45 \mathrm{H}$ & $93-02-15$ & $775.71 \mathrm{H}$ & & \\
\hline $89-01-15$ & $775.45 \mathrm{H}$ & $93-03-15$ & $775.61 \mathrm{H}$ & & \\
\hline $89-02-15$ & $775.48 \mathrm{H}$ & $93-04-15$ & $775.55 \mathrm{H}$ & & \\
\hline $89-03-15$ & $775.50 \mathrm{H}$ & $93-05-15$ & $775.58 \mathrm{H}$ & & \\
\hline $89-04-15$ & $775.49 \mathrm{H}$ & $93-06-15$ & $775.58 \mathrm{H}$ & & \\
\hline $89-05-15$ & $775.49 \mathrm{H}$ & $93-07-15$ & $775.55 \mathrm{H}$ & & \\
\hline $89-06-15$ & $775.49 \mathrm{H}$ & $93-08-15$ & $775.55 \mathrm{H}$ & & \\
\hline $89-07-15$ & $775.47 \mathrm{H}$ & $93-09-15$ & $775.56 \mathrm{H}$ & & \\
\hline $89-11-15$ & $775.50 \mathrm{H}$ & $93-10-15$ & $775.56 \mathrm{H}$ & & \\
\hline $89-12-15$ & $775.54 \mathrm{H}$ & $93-11-15$ & $775.56 \mathrm{H}$ & & \\
\hline $90-06-15$ & $775.51 \mathrm{H}$ & $93-12-15$ & $775.55 \mathrm{H}$ & & \\
\hline
\end{tabular}

${ }^{1}$ Actual date of measurement applies to manual measurements only. For monthly mean water levels, the 15 th of each month was used. This was done to facilitate the plotting of the hydrographs for this report. 


\section{Well USW H-5, Lower Zone}

$[M$, indicates manual water-level measurement; $H$, indicates monthly mean water levels averaged from hourly transducer data]

\begin{tabular}{|c|c|c|c|}
\hline $\begin{array}{c}\text { Date }^{1} \\
\text { (year-month-day) }\end{array}$ & $\begin{array}{c}\text { Water-level } \\
\text { altitude } \\
\text { (meters) }\end{array}$ & $\begin{array}{c}\text { Date }^{1} \\
\text { (year-month-day) }\end{array}$ & $\begin{array}{l}\text { Water-level } \\
\text { altitude } \\
\text { (meters) }\end{array}$ \\
\hline $85-01-04$ & $774.95 \mathrm{M}$ & $94-07-15$ & $775.61 \mathrm{H}$ \\
\hline $85-01-19$ & $775.10 \mathrm{M}$ & $94-08-15$ & $775.63 \mathrm{H}$ \\
\hline $85-02-05$ & $775.07 \mathrm{M}$ & $95-01-15$ & $775.86 \mathrm{H}$ \\
\hline $85-02-22$ & $775.11 \mathrm{M}$ & $95-02-15$ & $775.75 \mathrm{H}$ \\
\hline $87-09-24$ & $775.46 \mathrm{M}$ & $95-03-15$ & $775.85 \mathrm{H}$ \\
\hline $90-06-15$ & $775.61 \mathrm{H}$ & $95-04-15$ & $775.85 \mathrm{H}$ \\
\hline $90-07-15$ & $775.60 \mathrm{H}$ & $95-05-15$ & $775.81 \mathrm{H}$ \\
\hline $90-08-15$ & $775.59 \mathrm{H}$ & $95-06-15$ & $775.75 \mathrm{H}$ \\
\hline $90-09-15$ & $775.59 \mathrm{H}$ & $95-07-15$ & $775.76 \mathrm{H}$ \\
\hline $90-10-15$ & $775.59 \mathrm{H}$ & $95-08-15$ & $775.76 \mathrm{H}$ \\
\hline $90-11-15$ & $775.60 \mathrm{H}$ & $95-09-15$ & $775.72 \mathrm{H}$ \\
\hline $90-12-15$ & $775.63 \mathrm{H}$ & $95-10-15$ & $775.70 \mathrm{H}$ \\
\hline $91-01-15$ & $775.61 \mathrm{H}$ & $95-12-15$ & $775.76 \mathrm{H}$ \\
\hline $91-02-15$ & $775.64 \mathrm{H}$ & & \\
\hline $91-03-15$ & $775.70 \mathrm{H}$ & & \\
\hline $91-04-15$ & $775.68 \mathrm{H}$ & & \\
\hline $91-05-15$ & $775.70 \mathrm{H}$ & & \\
\hline $91-06-15$ & $775.66 \mathrm{H}$ & & \\
\hline $91-07-15$ & $775.62 \mathrm{H}$ & & \\
\hline $91-08-15$ & $775.63 \mathrm{H}$ & & \\
\hline $91-09-15$ & $775.65 \mathrm{H}$ & & \\
\hline $92-01-15$ & $775.62 \mathrm{H}$ & & \\
\hline $92-02-15$ & $775.65 \mathrm{H}$ & & \\
\hline $92-03-15$ & $775.61 \mathrm{H}$ & & \\
\hline $92-04-15$ & $775.53 \mathrm{H}$ & & \\
\hline $92-05-15$ & $775.45 \mathrm{H}$ & & \\
\hline $92-06-15$ & $775.53 \mathrm{H}$ & & \\
\hline $92-07-15$ & $775.56 \mathrm{H}$ & & \\
\hline $92-08-15$ & $775.48 \mathrm{H}$ & & \\
\hline $92-09-15$ & $775.53 \mathrm{H}$ & & \\
\hline 93-04-15 & $775.64 \mathrm{H}$ & & \\
\hline $93-05-15$ & $775.74 \mathrm{H}$ & & \\
\hline $93-06-15$ & $775.78 \mathrm{H}$ & & \\
\hline $93-07-15$ & $775.79 \mathrm{H}$ & & \\
\hline $93-08-15$ & $775.79 \mathrm{H}$ & & \\
\hline $93-09-15$ & $775.75 \mathrm{H}$ & & \\
\hline $94-01-15$ & $775.69 \mathrm{H}$ & & \\
\hline $94-02-15$ & $775.71 \mathrm{H}$ & & \\
\hline $94-03-15$ & $775.64 \mathrm{H}$ & & \\
\hline $94-04-15$ & $775.62 \mathrm{H}$ & & \\
\hline $94-05-15$ & $775.66 \mathrm{H}$ & & \\
\hline $94-06-15$ & $775.67 \mathrm{H}$ & & \\
\hline
\end{tabular}

${ }^{1}$ Actual date of measurement applies to manual measurements only. For monthly mean water levels, the 15 th of each month was used. This was done to facilitate the plotting of the hydrographs for this report. 


\section{Well USW H-6, Upper Zone}

[M, indicates manual water-level measurement; $\mathrm{H}$, indicates monthly mean water levels averaged from hourly transducer data]

\begin{tabular}{|c|c|c|c|c|c|}
\hline $\begin{array}{c}\text { Date }^{\top} \\
\text { (year-month-day) }\end{array}$ & $\begin{array}{l}\text { Water-level } \\
\text { altitude } \\
\text { (meters) }\end{array}$ & $\begin{array}{c}\text { Date }^{1} \\
\text { (year-month-day) }\end{array}$ & $\begin{array}{c}\text { Water-level } \\
\text { altitude } \\
\text { (meters) }\end{array}$ & $\begin{array}{c}\text { Date }^{1} \\
\text { (year-month-day) }\end{array}$ & $\begin{array}{l}\text { Water-level } \\
\text { altitude } \\
\text { (meters) }\end{array}$ \\
\hline $85-08-15$ & $775.91 \mathrm{H}$ & $89-06-15$ & $775.84 \mathrm{H}$ & $93-01-15$ & $776.07 \mathrm{H}$ \\
\hline $85-09-15$ & $775.95 \mathrm{H}$ & $89-07-15$ & $775.86 \mathrm{H}$ & $93-02-15$ & $776.09 \mathrm{H}$ \\
\hline $85-10-15$ & $775.96 \mathrm{H}$ & $89-08-15$ & $775.91 \mathrm{H}$ & $93-03-15$ & $776.07 \mathrm{H}$ \\
\hline $85-11-15$ & $775.98 \mathrm{H}$ & $89-09-15$ & $775.92 \mathrm{H}$ & $93-04-15$ & $776.09 \mathrm{H}$ \\
\hline $85-12-15$ & $775.99 \mathrm{H}$ & $89-10-15$ & $775.92 \mathrm{H}$ & $93-05-15$ & $776.09 \mathrm{H}$ \\
\hline $86-01-15$ & $776.03 \mathrm{H}$ & $89-11-15$ & $775.90 \mathrm{H}$ & $93-06-15$ & $776.09 \mathrm{H}$ \\
\hline $86-02-15$ & $776.05 \mathrm{H}$ & $89-12-15$ & $775.90 \mathrm{H}$ & $93-07-15$ & $776.06 \mathrm{H}$ \\
\hline $86-03-15$ & $776.05 \mathrm{H}$ & $90-01-15$ & $775.91 \mathrm{H}$ & $93-08-15$ & $776.07 \mathrm{H}$ \\
\hline $86-04-15$ & $776.09 \mathrm{H}$ & $90-02-15$ & $775.89 \mathrm{H}$ & $93-09-15$ & $776.07 \mathrm{H}$ \\
\hline $86-05-15$ & $776.08 \mathrm{H}$ & $90-03-15$ & $775.96 \mathrm{H}$ & $93-10-15$ & $776.07 \mathrm{H}$ \\
\hline $86-06-15$ & $776.06 \mathrm{H}$ & $90-04-15$ & $775.93 \mathrm{H}$ & $93-11-15$ & $776.05 \mathrm{H}$ \\
\hline $86-07-15$ & $776.09 \mathrm{H}$ & $90-05-15$ & $775.96 \mathrm{H}$ & $93-12-15$ & $776.05 \mathrm{H}$ \\
\hline $86-08-15$ & $776.12 \mathrm{H}$ & $90-06-15$ & $775.98 \mathrm{H}$ & $94-01-15$ & $776.08 \mathrm{H}$ \\
\hline $86-09-15$ & $776.15 \mathrm{H}$ & $90-07-15$ & $776.01 \mathrm{H}$ & $94-02-15$ & $776.10 \mathrm{H}$ \\
\hline $86-10-15$ & $776.11 \mathrm{H}$ & $90-08-15$ & $776.01 \mathrm{H}$ & $94-03-15$ & $776.10 \mathrm{H}$ \\
\hline $86-11-15$ & $776.14 \mathrm{H}$ & $90-09-15$ & $775.93 \mathrm{H}$ & $94-04-15$ & $776.04 \mathrm{H}$ \\
\hline $86-12-15$ & $776.16 \mathrm{H}$ & $90-10-15$ & $775.89 \mathrm{H}$ & $94-05-15$ & $776.09 \mathrm{H}$ \\
\hline $87-01-15$ & $776.19 \mathrm{H}$ & $90-11-15$ & $775.88 \mathrm{H}$ & $94-06-15$ & $776.10 \mathrm{H}$ \\
\hline $87-02-15$ & $776.20 \mathrm{H}$ & $90-12-15$ & $775.91 \mathrm{H}$ & $94-07-15$ & $776.10 \mathrm{H}$ \\
\hline $87-03-15$ & $776.16 \mathrm{H}$ & $91-01-15$ & $775.88 \mathrm{H}$ & $94-08-15$ & $776.11 \mathrm{H}$ \\
\hline $87-04-15$ & $776.11 \mathrm{H}$ & $91-03-15$ & $775.92 \mathrm{H}$ & $94-09-15$ & $776.11 \mathrm{H}$ \\
\hline $87-05-15$ & $776.02 \mathrm{H}$ & 91-04-15 & $775.99 \mathrm{H}$ & $94-10-15$ & $776.14 \mathrm{H}$ \\
\hline $87-06-15$ & $776.02 \mathrm{H}$ & $91-05-15$ & $776.01 \mathrm{H}$ & $94-11-15$ & $776.15 \mathrm{H}$ \\
\hline $87-07-15$ & $776.02 \mathrm{H}$ & $91-06-15$ & $776.00 \mathrm{H}$ & $94-12-15$ & $776.18 \mathrm{H}$ \\
\hline $87-08-15$ & $776.03 \mathrm{H}$ & $91-07-15$ & $775.98 \mathrm{H}$ & $95-01-15$ & $776.19 \mathrm{H}$ \\
\hline $87-09-15$ & $776.04 \mathrm{H}$ & $91-08-15$ & $776.00 \mathrm{H}$ & $95-02-15$ & $776.13 \mathrm{H}$ \\
\hline $87-10-15$ & $776.00 \mathrm{H}$ & $91-09-15$ & $776.00 \mathrm{H}$ & $95-03-15$ & $776.13 \mathrm{H}$ \\
\hline $87-11-15$ & $775.93 \mathrm{H}$ & $91-10-15$ & $776.01 \mathrm{H}$ & $95-04-15$ & $776.13 \mathrm{H}$ \\
\hline $87-12-15$ & $775.88 \mathrm{H}$ & $91-11-15$ & $775.99 \mathrm{H}$ & $95-05-15$ & $776.10 \mathrm{H}$ \\
\hline $88-05-15$ & $775.98 \mathrm{H}$ & $91-12-15$ & $775.99 \mathrm{H}$ & $95-06-15$ & $776.11 \mathrm{H}$ \\
\hline $88-06-15$ & $775.96 \mathrm{H}$ & $92-01-15$ & $775.96 \mathrm{H}$ & $95-07-15$ & $776.11 \mathrm{H}$ \\
\hline $88-07-15$ & $775.94 \mathrm{H}$ & $92-02-15$ & $775.96 \mathrm{H}$ & $95-08-15$ & $776.13 \mathrm{H}$ \\
\hline $88-08-15$ & $775.95 \mathrm{H}$ & $92-03-15$ & $775.99 \mathrm{H}$ & $95-09-15$ & $776.15 \mathrm{H}$ \\
\hline $88-09-15$ & $775.94 \mathrm{H}$ & $92-04-15$ & $775.99 \mathrm{H}$ & $95-12-06$ & $776.10 \mathrm{M}$ \\
\hline $88-10-15$ & $775.95 \mathrm{H}$ & $92-05-15$ & $776.04 \mathrm{H}$ & & \\
\hline $88-11-15$ & $775.95 \mathrm{H}$ & $92-06-15$ & $776.05 \mathrm{H}$ & & \\
\hline $88-12-15$ & $775.93 \mathrm{H}$ & $92-07-15$ & $776.04 \mathrm{H}$ & & \\
\hline $89-01-15$ & $775.96 \mathrm{H}$ & $92-08-15$ & $776.05 \mathrm{H}$ & & \\
\hline $89-02-15$ & $775.99 \mathrm{H}$ & $92-09-15$ & $776.06 \mathrm{H}$ & & \\
\hline $89-03-15$ & $775.99 \mathrm{H}$ & $92-10-15$ & $776.07 \mathrm{H}$ & & \\
\hline $89-04-15$ & $775.83 \mathrm{H}$ & $92-11-15$ & $776.02 \mathrm{H}$ & & \\
\hline $89-05-15$ & $775.83 \mathrm{H}$ & $92-12-15$ & $776.06 \mathrm{H}$ & & \\
\hline
\end{tabular}

${ }^{1}$ Actual date of measurement applies to manual measurements only. For monthly mean water levels, the 15 th of each month was used. This was done to facilitate the plotting of the hydrographs for this report. 
Well USW H-6, Lower Zone

$[\mathrm{M}$, indicates manual water-level measurement; $\mathrm{H}$, indicates monthly mean water levels averaged from hourly transducer data]

\begin{tabular}{|c|c|c|c|}
\hline $\begin{array}{c}\text { Date }^{1} \\
\text { (year-month-day) }\end{array}$ & $\begin{array}{c}\text { Water-level } \\
\text { altitude } \\
\text { (meters) }\end{array}$ & $\begin{array}{c}\text { Date }^{1} \\
\text { (year-month-day) }\end{array}$ & $\begin{array}{l}\text { Water-level } \\
\text { altitude } \\
\text { (meters) }\end{array}$ \\
\hline $88-02-23$ & $775.90 \mathrm{M}$ & $92-08-15$ & $775.80 \mathrm{H}$ \\
\hline $88-06-13$ & $775.88 \mathrm{M}$ & $92-09-15$ & $775.90 \mathrm{H}$ \\
\hline $88-10-21$ & $775.90 \mathrm{M}$ & $92-10-15$ & $775.98 \mathrm{H}$ \\
\hline $89-04-15$ & $775.94 \mathrm{H}$ & $92-11-15$ & $775.98 \mathrm{H}$ \\
\hline $89-05-15$ & $775.94 \mathrm{H}$ & $92-12-15$ & $776.07 \mathrm{H}$ \\
\hline $89-06-15$ & $775.93 \mathrm{H}$ & $93-01-15$ & $776.00 \mathrm{H}$ \\
\hline $89-07-15$ & $775.91 \mathrm{H}$ & $93-02-15$ & $776.00 \mathrm{H}$ \\
\hline 89-08-15 & $775.94 \mathrm{H}$ & $93-03-15$ & $775.95 \mathrm{H}$ \\
\hline 89-09-15 & $775.93 \mathrm{H}$ & $93-04-15$ & $775.95 \mathrm{H}$ \\
\hline $89-10-15$ & $775.92 \mathrm{H}$ & $93-05-15$ & $775.98 \mathrm{H}$ \\
\hline $89-11-15$ & $775.94 \mathrm{H}$ & $93-06-15$ & $775.97 \mathrm{H}$ \\
\hline $89-12-15$ & $775.96 \mathrm{H}$ & $93-07-15$ & $776.00 \mathrm{H}$ \\
\hline $90-01-15$ & $775.95 \mathrm{H}$ & $93-08-15$ & $775.97 \mathrm{H}$ \\
\hline $90-02-15$ & $775.95 \mathrm{H}$ & $93-09-15$ & $775.90 \mathrm{H}$ \\
\hline $90-03-15$ & $775.98 \mathrm{H}$ & $93-10-15$ & $775.97 \mathrm{H}$ \\
\hline $90-04-15$ & $775.98 \mathrm{H}$ & $93-12-15$ & $776.08 \mathrm{H}$ \\
\hline $90-05-15$ & $775.94 \mathrm{H}$ & $94-01-15$ & $776.05 \mathrm{H}$ \\
\hline $90-06-15$ & $775.90 \mathrm{H}$ & $94-02-15$ & $775.97 \mathrm{H}$ \\
\hline $90-07-15$ & $775.90 \mathrm{H}$ & $94-03-15$ & $775.97 \mathrm{H}$ \\
\hline $90-08-15$ & $775.87 \mathrm{H}$ & $94-04-15$ & $776.02 \mathrm{H}$ \\
\hline $90-09-15$ & $775.91 \mathrm{H}$ & $94-06-15$ & $775.97 \mathrm{H}$ \\
\hline $90-10-15$ & $775.81 \mathrm{H}$ & $94-07-15$ & $775.98 \mathrm{H}$ \\
\hline $90-11-15$ & $775.74 \mathrm{H}$ & $94-08-15$ & $775.99 \mathrm{H}$ \\
\hline $90-12-15$ & $775.74 \mathrm{H}$ & $94-09-15$ & $776.00 \mathrm{H}$ \\
\hline $91-01-15$ & $775.71 \mathrm{H}$ & $94-10-15$ & $776.08 \mathrm{H}$ \\
\hline $91-03-15$ & $775.94 \mathrm{H}$ & $94-11-15$ & $775.93 \mathrm{H}$ \\
\hline $91-04-15$ & $775.93 \mathrm{H}$ & $94-12-15$ & $775.98 \mathrm{H}$ \\
\hline $91-05-15$ & $775.93 \mathrm{H}$ & $95-01-15$ & $776.00 \mathrm{H}$ \\
\hline $91-06-15$ & $775.91 \mathrm{H}$ & $95-02-15$ & $776.05 \mathrm{H}$ \\
\hline $91-07-15$ & $775.90 \mathrm{H}$ & $95-03-15$ & $776.01 \mathrm{H}$ \\
\hline $91-08-15$ & $775.91 \mathrm{H}$ & $95-04-15$ & $775.98 \mathrm{H}$ \\
\hline $91-09-15$ & $775.91 \mathrm{H}$ & $95-05-15$ & $775.98 \mathrm{H}$ \\
\hline $91-10-15$ & $775.91 \mathrm{H}$ & $95-06-15$ & $775.99 \mathrm{H}$ \\
\hline $91-11-15$ & $775.89 \mathrm{H}$ & $95-07-15$ & $776.01 \mathrm{H}$ \\
\hline $91-12-15$ & $775.88 \mathrm{H}$ & $95-08-15$ & $776.03 \mathrm{H}$ \\
\hline $92-01-15$ & $775.85 \mathrm{H}$ & $95-09-15$ & $776.04 \mathrm{H}$ \\
\hline $92-02-15$ & $775.87 \mathrm{H}$ & $95-12-06$ & $775.98 \mathrm{M}$ \\
\hline $92-03-15$ & $775.97 \mathrm{H}$ & & \\
\hline $92-04-15$ & $775.96 \mathrm{H}$ & & \\
\hline $92-05-15$ & $775.93 \mathrm{H}$ & & \\
\hline $92-06-15$ & $775.97 \mathrm{H}$ & & \\
\hline $92-07-15$ & $775.90 \mathrm{H}$ & & \\
\hline
\end{tabular}

${ }^{1}$ Actual date of measurement applies to manual measurements only. For monthly mean water levels, the 15th of each month was used. This was done to facilitate the plotting of the hydrographs for this report. 


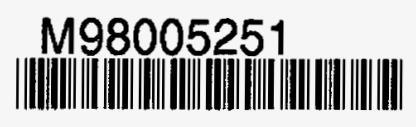

Report Number (14) US6S/WRIR--96-4256

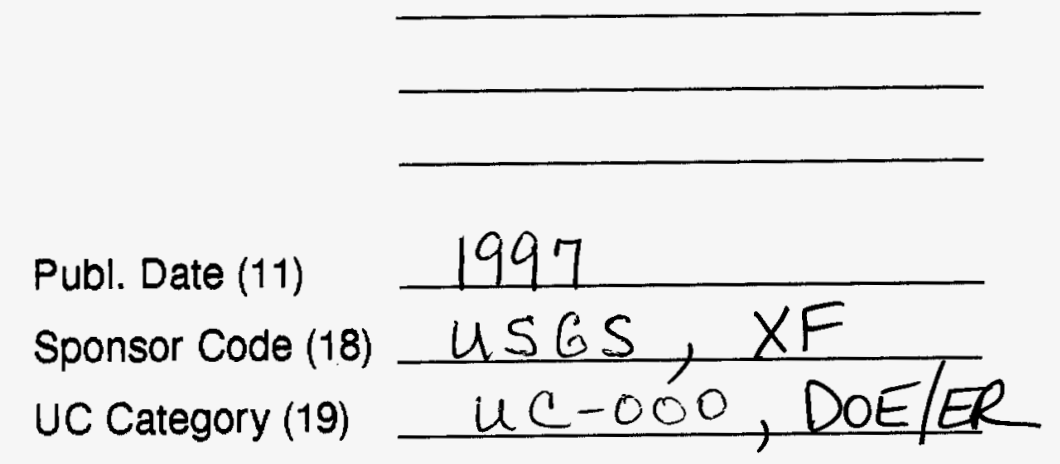

19980622074 